\title{
Democratic Intellect: Freeing Thought for the
}

\author{
Democracy To-come
}

\author{
By \\ Jafar Mirzaee Porkoli
}

\begin{abstract}
A thesis
submitted to the Victoria University of Wellington in fulfilment of the requirements for the degree of

Doctor of Philosophy
\end{abstract}

Victoria University of Wellington 


\section{Table of Contents}

$\begin{array}{ll}\text { Acknowledgements } & 4\end{array}$

$\begin{array}{ll}\text { Abstract } & 5\end{array}$

$\begin{array}{ll}\text { Introduction } & 7\end{array}$

Chapter One: The Question of Exemplarity and Singular Examples 43

Chapter Two: Public Space without Conditions $\quad 77$

Chapter Three: Justice: Neither of Law nor as Law, but beyond Law 107

Chapter Four: Critique of Violence: "Fit Reader" Does Justice on the Lawless King 155

Chapter Five: The Lawless Institution of Literature 187

Chapter Six: The Aporetic Moment/Space of Decision and the Poetics of the To-come

in Paradise Regained 235

Chapter Seven: The Aporetic Moment/Space of Decision and the Poetics of the To-

come in Samson Agonistes 295

$\begin{array}{ll}\text { Conclusion } & 347\end{array}$

$\begin{array}{ll}\text { Bibliography } & 357\end{array}$ 


\section{Acknowledgements}

The completion of this thesis would have been impossible without the dedicated academic guidance, support, and wisdom of my supervisor, Dr Brian Opie. Has it not been for his incompatible patience, encouragement, and knowledge, I would have not been able to enjoy the challenging and extraordinary moments of reading Jacques Derrida and John Milton. I wholeheartedly believe that, for the past five years, the presence of Brian's generosity, support, and patience in my life has been an absolute "gift" to me and my family.

It is essential to thank Linda Hardy who was supportive during the primary phase of my studies at Victoria University of Wellington. My sincerest thanks also go to the staff and people in the English Department at Victoria University of Wellington for providing a supportive and encouraging academic environment to work in.

Most especially, I would like to thank my family and friends for their invaluable support and kindness. 


\begin{abstract}
The core argument of this thesis is on the aporetic moment/space of decision and the poetics of the to-come in John Milton's works, with the fundamental importance of the individual. For Milton, this moment/space is radically critical and free, and individually problematic, which goes beyond the usual private/public space even though the public aspects and responsibilities of the person's decision demonstrate exceptional significance in the form of public enactment. In Milton's terms, the experience of such an aporetic moment/space of decision is indispensible for those who want to become a "fit reader" and develop the essential qualities and attributes. I will argue that Milton has always written with the desire to highlight and exemplify the absolute singularity of such a moment and experience throughout his life and works, both prose and poetry.
\end{abstract}

The thesis will represent its arguments in two sections. The first section, through a consideration of Derrida's arguments in his works (in particular: "The Laws of Reflection: Nelson Mandela, in Admiration," "The Future of the Profession or the Unconditional University," "Force of Law: The 'Mystical Foundation of Authority,", and "This Strange Institution Called Literature") together with a selection of Milton's writings, mainly prose (including: Areopagitica, Eikonoklastes, The Tenure of Kings and Magistrates, and Paradise Lost), will examine and identify possible continuities and convergences between the two writers. Such an intimate juxtaposition and close reading of their works has promisingly offered recognition of continuities, convergences, and affinities in their thought in terms of the qualities and attributes of the "fit reader" and the "democratic intellect." In the opening five chapters, the interactive reading highlights fundamental questions and notions for both writers, including the question of exemplarity or singularity, the notion of public space without conditions, the question of justice beyond the law, the critique of violence, and the question of literature as a lawless institution, providing me with the essential terminology to formulate new interpretations of Milton's works, in particular, Paradise Regained and Samson Agonistes. 
The second part of the thesis uses the conceptions and terms developed in the opening chapters to read the two late poems, Paradise Regained and Samson Agonistes, as singular examples of Milton's fit reader, the aporetic moment/space of decision, and the poetics of the to-come by setting out the general comparative points between them. The focus of my arguments in these chapters will be on the hypothesis that Paradise Regained and Samson Agonistes are both demonstrating the aporetic moment/space of decision - confusingly replete with uncertainties, complexities, and indeterminacies and the dominant poetics of the to-come as well as arguing for the singularity of the moment, decision, and enactment of the decision in each poem. I will argue that Paradise Regained and Samson Agonistes provide outstanding exemplifications of Milton's notion of the "fit reader" developing similar qualities and attributes in common with Derrida's "democratic intellect."

Milton's works represent the aporetic moment/space of decision as an ongoing process; it is a singular moment in which uncertainties and indeterminacies produce unresolvable choices, but where a decision must nonetheless be made; it is a moment of "trial" the result of which cannot be known to the individual "fit reader" in advance. Milton's late poems, Paradise Regained and Samson Agonistes, explore the critical significance of this moment and demonstrate that no certain, fixed, pre-programmed, or predetermined model or frame can be applied to the resolution of aporetic moments of decision in different times, places, and contexts. The "fit reader" is one who radically and critically reads and re-reads aporetic situations, full of inescapable indeterminacies and unresolved choices, and expresses his individual judgement in the singular form of a true decision (not calculation) to advance the possibilities of truth, justice, and humanity. 


\section{Introduction}

Individuals are the main sources and forces of changes and development in societies. They are readers of the issues and problems in their societies whose decisions affect the society in which they live. Given this fundamental function of individuals in a society, thinkers and theorists have made the development and demonstration of reading methods a primary concern. What is the best strategy to examine, analyze, or generally read the issues of society and make a true and just decision which would create a better situation in that society? The continuing enquiry from which this thesis would draw its energy is what a democratic society can or should be like. This is precisely the question that John Milton engaged with in his writings throughout his life. The thesis will be exploring the centrality of his conception of human thought and action in Milton's thinking throughout his life as it is expressed in Areopagitica: ${ }^{1}$

When God gave him [Adam] reason, he gave him freedom to choose, for reason is but choosing; he had been else a mere artificial Adam, such an Adam as he is in the motions. We ourselves esteem not of that obedience, or love, or gift, which is of force. God therefore left him free, set before him a

\footnotetext{
${ }^{1}$ All references to Milton's Areopagitica, The Tenure of Kings and Magistrates, Paradise Lost, Paradise Regained, and Samson Agonistes will be to The Complete Poetry and Essential Prose of John Milton. Ed. William Kerrigan, John Rumrich, and Stephen M. Fallon. New York: Modern Library, 2007. The references to Eikonoklastes will be to volume three of The Complete Prose Works of John Milton. Ed. Merritt Y. Hughes. New Haven: Yale UP, 1953.
} 
provoking object, ever almost in his eyes herein consisted his merit, herein the right of his reward, the praise of his abstinence. (944)

It is the absolute responsibility of everyone to reason and make a decision. For Milton, true decision-making is an individual mental process and action. How central, and radical in its implications for the interpretation of Milton's poetry, this particular view of decision-making is can be perceived by reading his texts in conjunction with Jacques Derrida's. In respect of the traditions of democratic thought, Derrida's views about the origins of modern democracy and modern literature provide a strong justification for considering Milton and Derrida as standard-bearers for a strong conception of democracy in the western humanist tradition. For Derrida, the principle to say everything is a fundamental feature of his conception of democracy and literature. In Acts of Literature, Derrida argues that:

The institution of literature in the West, in its relatively modern form, is linked to an authorization to say everything, and doubtless too to the coming about of the modern idea of democracy. Not that it depends on a democracy in place, but it seems inseparable to me from what calls forth a democracy, in the most open (and doubtless itself to come) sense of democracy. (37)

From Derrida's perspective, therefore, the modern notions of literature and democracy have similar origins mainly due to the indispensability of the fundamental principle to say everything, which goes back "for only a few centuries" (71, to the seventeenth 
century). To understand the modern concept of literature, he argues, we have to "discern exactly the historically determined phenomenon of social conventions and the institutions which give rise, give its place, to literature" (71). In his introduction to Acts of Literature, Derek Attridge asserts that "The institution of literature, especially as we have known it in the Western democracies since the seventeenth or eighteenth century, has certain features that make it an unusual member of the set of verbal practices around us, and Derrida stresses this peculiarity" (23). Consequently, for Derrida, the origins of the modern notions of democracy and literature fall around Milton's time and the time of civil war in England when the social conventions and institutions began to adopt modern democratic, humanistic features. Derrida emphatically underlines the inseparable relations between modern notions of democracy and literature:

Literature is a modern invention, inscribed in conventions and institutions which, to hold on to just this trait, secure in principle its right to say everything. Literature thus ties its destiny to a certain noncensure, to the space of democratic freedom (freedom of the press, freedom of speech, etc.). No democracy without literature; no literature without democracy. One can always want neither one nor the other, and there is no shortage of doing without them under all regimes; it is quite possible to consider neither of them to be unconditional goods and indispensible rights. But in no case can one dissociate one from the other. No analysis would be equal to it. And each time that a literary work is censured, democracy is in danger, as everyone agrees. The possibility of literature, the legitimation that a society 
gives it, the allaying of suspicion or terror with regard to it, all that goes together-politically-with the unlimited right to ask any question, to suspect all dogmatism, to analyze every presupposition, even those of the ethics or the politics of responsibility. (On the Name 28 , his emphasis)

In these terms, we can position Milton at the origin point indicated by Derrida, and hence propose a genealogical relation between them. Milton criticism continues to seek to locate Milton both in his times and ours, and this thesis will demonstrate how concepts developed by Derrida in his own time can provide a fuller understanding of a crucial element in Milton's thinking about the formation of democracy as an historical and contextual process, the role of decision-making as an individual mental action.

In Paradise Lost, Milton invokes Urania to govern his song "and fit audience find, though few" (7. 31). In Areopagitica, he argues that "there is no reason that we should deprive a wise man of any advantage to his wisdom" just because we seek to restrain those "unfit for his reading" (941). Milton targeted his epic towards "a select few," those who in his eyes were fit to read and judge. His model readers are "fit readers" with individual qualities and capabilities. But who is Milton's fit reader and what are the qualities and attributes of the model of fit reading as Milton developed it? These are the core questions that will be explored in connection with Derrida's views in this thesis because he is concerned with similar questions. His deconstructive strategy institutes a model of radically critical and free reading. Derrida's concern, in his works, is to demonstrate and underline the qualities and attributes of deconstructive reading. In his 
thought, the term "democratic intellect" refers to the distinctive quality of someone who shows the desire and potential to apply such a revolutionary reading method. Who possesses a democratic intellect? What are the specifics of radically critical and free reading? Likewise, the question of decision-making plays a fundamental role in his thought. He attempts to demonstrate the way a democratic intellect must exercise radically critical and free reading and make a true and just decision the aim of which is to move a society towards a better but unpredictable and unknown form of democracy or humanity to come.

My argument is that Milton and Derrida are fundamentally committed to the same conception, the notion of fit reader/democratic intellect or fit/radically critical and free reading. Both authors emphasize the importance of the singularity and every individual conscience, mind, and reason for the evolution of a true democracy. This promising juxtaposition enables us to recontextualize Milton with Derrida and shows that the elements that make deconstruction possible are working in Milton as well. Although Milton formulates those elements in ways appropriate to his own historical and cultural context and Derrida in a context closer to us, reading both thinkers together affirms that there is an intimate connection between them in the traditions of European literature and Western humanism. The connection is imaginable in terms of the notions of modern democracy and literature and the significance of decision-making as an individual mental action. The aim of this exploration is not to proclaim the complete similarity of their thought and philosophy. It also does not attempt to apply a deconstructive reading to Milton's works. Instead, the argument of the thesis will affirm the claim that Milton 
is part of Derrida's genealogy. In Reading Derrida/Thinking Paul: On Justice, Theodore W. Jennings concludes his argument in a highly pertinent way which affirms the juxtaposition that this thesis intends to explore:

The point of these reflections, however, is not to ask or answer whether Derrida is in some odd sense a Christian or even a Paulinist, or whether Paul is a proto-deconstructionist. The point, rather, is that both Paul and Derrida are wrestling with questions that are urgent for their respective civilizations, above all the question of justice. And it is because they are wrestling with precisely these questions that they may be seen to engage one another's projects in interesting and illuminating ways. (176)

It is essential to acknowledge another example of the juxtaposition and recontextualization of two writers living in different times. Donald L. Guss, in his essay, "Enlightenment as Process: Milton and Habermas," argues that Milton and Habermas have continuities and common features: "Against tyranny and custom, both Milton and Habermas assert universal but suspended values, absolute but partially known truths. Both seek freedom in discourse, a process that gives things the meanings they have for us. To constitute self and world, though, Milton has God's Word and Man's, Habermas the human word alone" (1164). His argument is that the focus and context of reasoning for both Milton and Habermas is social. He contends that the engagement of both authors with the concept of enlightenment in connection to their own societies shows common relationships between them. For him, Habermas reformulates the concept of 
enlightenment while Milton presages it. Even though Guss is not engaged with deconstruction and Derrida's position in his essay, ${ }^{2}$ his argument evinces that Milton is against hegemony, authority, fixity, or deterministic structures. He truly argues that reasoning is not a process or activity out of which we should expect the generation of predictable conclusions. The reasoning process includes instability, indeterminacy, and uncertainty. Besides, the hegemonic powers of a society typically endeavour to establish control over the systems of signs in society. In other words, signs as institutionalized discursive hegemony block understanding and discourse and Milton writes challengingly against them in his works throughout his life. His main desire and struggle is to radically and critically open up and free the established discursive systems. I acknowledge these strong relationships between Guss' argument in his essay and my argument here in terms of the question of reason, the process of decisionmaking and the social engagement of a democratic mind in Milton's works.

It seems undeniable that individuals in the same society share common qualities and attributes; however, in going through the process of making a true decision they question, re-examine, and reframe them so that the burden of their decision is placed squarely on the individual. In other words, within a social, historical, and cultural framework which produces a variety of individuals (namely the Son of God, Samson, Dalila, Harapha, Manoa), Milton highlights the social dimension as a decisive factor.

\footnotetext{
${ }^{2}$ Guss' argument demonstrates that he understands deconstruction as a theoretical practice with a set of philosophical propositions. This would turn deconstruction into another kind of fundamentalist or metaphysical method or approach. My understanding of deconstruction or Derrida's position demonstrated here is against such a metaphysical perception of them.
} 
The outcome of a decision-making process has to be enacted in a social environment where it makes a difference. It is through such an extremely difficult and intense process that the reason and the rationality of the society can expand and increase. This is the vital significance of decision-making as a process. The individual decision is to be realized in the public sphere. Milton's act in writing Areopagitica and addressing the Parliament is a good example and practical evidence of such an act, which uniquely demonstrates the importance of the social and public dimension of an individual decision.

Nonetheless, the argument of my thesis is that Milton has something more to offer about the importance of social engagements and interactions, which fundamentally differentiates him from Habermas and brings him close to Derrida's position. Milton and Derrida emphasize the question of singularity and the fundamental weight of every individual conscience, mind, and reason in a true democracy. The role and importance of every person in society is categorically important. Everyone in society must feel the burden of this responsibility. The focus of my argument will be on Milton's attempt to demonstrate the radical grounding of all of these themes and issues in an individual subject. However, it is essential to remember that individuals, in Milton and Derrida's thought, should be engaged deeply and radically with the society in which they live. The possible Derridean relationship with Milton, which I will be presenting here, exposes more completely the particular aspects of Milton's approach, which Guss acknowledges but does not provide a complete account of them because Habermas' position about the concept of enlightenment prevents it to some extent. The characters 
Milton creates in his poetic works or those he addresses in his prose writings all become important in terms of his views on fit reading and the problematically uncertain moment/space of decision-making and the impacts of individuals' decisions on the society. In Samson Agonistes and Paradise Regained, Milton represents Samson and the Son of God as fully engaged in series of conversations with others in their society. These conversational interactions represent internal mental events in the moment of decision-making; nonetheless, they occur in exchanges with others in the society in which they live. The involvement of the self (of Samson and the Son of God) with these issues is not inherently and entirely private or subjective. Consequently, it is impossible to experience such a mental engagement or radically critical enquiry without considering its social context and dimension, even though the dominant emphasis is on the singular individual who makes a decision and demonstrates a position for himself or herself as a subjective process.

For me, Derrida extends the concept of democracy while Milton is at the modern origins of it. The governing assumption in both writers is that human societies are in constant change, environmental, social, political, economical, cultural, ideological, and so on. In a world in which the best conception of humanity may not provide a shared goal for the advancement of more fully humane societies, both writers locate the ultimate source of possibility for this advancement in the singular decisions and enactments of the individuals of that society. The question is how thought forms in the seventeenth century and in the secularized late twenty century can be wrapped over 
each other to demonstrate that Milton is giving similar weight to the same concepts and principles as Derrida when it comes to becoming a fit reader/democratic intellect.

What are the qualities and attributes of a fit reader/democratic intellect for Milton and Derrida? The similarities lie in the radical critique of fundamental questions performed in the moment of decision-making. In other words, the way a fit reader/democratic intellect approaches the crucial concepts and questions to make a true and just decision is through a radically critical and free reading method. Such a radical approach puts the fit reader/democratic intellect into a radical moment/space in which all the fundamental questions - certainties, norms, laws, principles, and knowledge - are suspended and radically reviewed, questioned, reassessed, and re-defined. Derrida's term for this moment/space is "aporia" without the experience of which there is no justice. In his essay in "Force of Law: The 'Mystical Foundation of Authority,"' published in Acts of Religion, Derrida argues that "there is no justice without this experience, however impossible it may be, of aporia. Justice is an experience of the impossible: a will, a desire, a demand for justice the structure of which would not be an experience of aporia, would have no chance to be what it is - namely, a just call for justice" (244, his emphasis). Nothing in such a mentally revolutionary moment/space is fixed, absolute, unquestionable, or certain. Everything is oriented towards the future.

Milton and Derrida, no matter what we call them (deconstructionist, heretic, nonconformist, protestant), put the focus of their thought and arguments within the domain of aporia. Both recognize the significance of the aporetic moment/space and make it the 
major theme of their works. Derrida refers to deconstruction as the experience of aporia or of the aporetic moment. This experience makes possible and governs our activities and thoughts. In this aporetic moment, law is radically challenged, rethought, reinterpreted, and reinstituted, and through it, justice might find ways to demonstrate itself. Justice remains always to come within this aporetic moment/space of decision without which there is no justice. What is common between them is that both think of justice as something other than the result, practice, and refinement of law. Both think of justice as the result of a true decision, which can only be the result of going through the aporetic moment/space of decision as an individual mental action. For Derrida this aporetic moment or interval, which Milton calls the moment of trial, is the primary factor in human history. In Areopagitica, Milton declares "that which purifies us is trial." Both Milton and Derrida recognize the significance of this experience and moment in shaping human history and individual lives. Milton thinks of history as the experience of aporia, the non-resolvable confusion after the Fall deriving from the clash and rupture between good and evil and the loss of unity in the world and human life.

To Derrida, in the aporetic moment/space of decision-making, the subject and the object of decision - the Who and the What of the decision - are not merely repeated and should not be only copies of previous subjects and objects. If you are to think of a singularity in relation to the concept of a true decision, not only the terms of the decision become indeterminate, uncertain, and undecidable but also the identity of the person who decides at that very moment of decision remains uncertain and indeterminate. In 
Deconstruction and Pragmatism, in response to pragmatists (in particular, to Richard Rorty), Derrida presents his argument on "the subject" and "the decision:"

The question here is whether it is through the decision that one becomes a subject who decides something. At the risk of appearing provocative, I would say that once one poses the question in that form and one imagines that the who and the what of the subject can be determined in advance, then there is no decision. In other words, the decision, if there is such a thing, must neutralize if not render impossible in advance the who and the what. If one knows, and if it is a subject that knows who and what, then the decision is simply the application of a law. In other words, if there is a decision, it presupposes that the subject of the decision does not yet exist and neither does the object. Thus with regard to the subject and the object, there will never be a decision. I think this summarizes a little what Ernesto Laclau proposed when he said that the decision presupposes identification, that is to say that the subject does not exist prior to the decision but when I decide I invent the subject. Every time I decide, if a decision is possible, I invent the who, and I decide who decides what; at this moment the question is not the who or the what but rather that of the decision, if there is such a thing. (86)

This account of the relation between the subject and object of a decision can be seen to apply to Milton's poems Paradise Regained and Samson Agonistes. We simply do not have an explanation and representation of the who and the what of the decision and the 
final act in these poems. It is the society in which Samson or the Son of God live that represents the who and the what of their decision making. In other words, the decision Samson made becomes the property of the community he is a part of and his father, Manoa, makes this explicit by commenting on Samson's final action and his life, saying that Samson has rejoined his main identity and by interpreting his action as the conventional fulfilment of his heroic life.

Therefore, Milton's purpose in withholding the conventional dying speech before Samson's crucial action exemplifies what Derrida is arguing above about the subject and the decision; that is, the actual in-determinability of any decision and the fact that a true decision does not simply proceed from a pre-established identity or formula within that society. This is illustrated in the cases of Samson and the Son of God because through the poems they are testing out options without having any certain directive. A crucial point for the interpretation of both poems is that Milton does not deliver an authoritative statement about the meaning of the final acts. Neither the Son of God nor Samson represent their explanations of the who and the what of the decision and the final act; the process of singular decisions manifested in their final actions does not carry any explanatory discourse with it. While this is not the case so completely in his other writings, the characters Milton creates in his poetic works or those he addresses in his prose writings are important for what they reveal about his views on fit reading, the problematically uncertain moment/space of decision-making and the impacts of individuals' decisions on society. 
In this thesis, I will propose that what I will term Milton's poetics of the to-come is most fully manifested in Paradise Regained and Samson Agonistes, which seek to focus our attention exclusively on the aporetic moment of decision-making. As the poems demonstrate, such a moment, if fully experienced, engages in an act of understanding all the resources of knowledge - moral, religious, historical, political, social, personal, and so forth - of the person in the specifics of their social and historical location. The purpose of this act of understanding is to reach a decision, which can be embodied in a public action for which the person is absolutely responsible and from whom it derives its integrity. This public action is individually acted out to assist the unpredictable development of a new form of society opening some new possibilities for democracy or humanity to come. Milton and Derrida are both investigating this question at their different historical locations in the ongoing evolution of the concept and practice of democratic society. The Son of God and Samson are not definitely citizens of democratic societies, but what is demonstrated as occurring in those poems is the same process of decision-making which is fundamental for Derrida in the configuration and continuation of democracy or humanity to-come. Although Milton's two late poems are located within a private mental domain, in many respects the process of decisionmaking is essentially social. The purpose of public action in both poems and in each of these events is to open their respective societies to democracy to-come or to new forms of possibilities for human society or humanity to-come. Even if neither of the central figures is operating in a democratic society, they provide crucial evidence of how to allow opening towards democracy or humanity to-come. An aporetic moment is distinctive because of being located on the margin between the present and the future 
and its potential is realized when its outcome leans toward the future rather than towards the past.

In the first part of the thesis, the argument is primarily concerned with Milton's prose works and Derrida's philosophical texts. What promisingly came through in the process of the research was the value of establishing the convergence between the notions of fit reader/democratic intellect, the indispensability of the experience of the aporetic moment/space of decision, and an emphasis on the notion of the to-come for both writers. These notions are defined for both writers by being "in history." That is precisely where Milton and Derrida's thought converge. At every point in Milton's poetry, characters are called on to make decisions, whether it is the Lady in Comus, or the Friend in Lycidas, or Satan or the Son of God in Paradise Lost. The same is the case in Milton's prose, where every proposition has contested interpretations, and one's life, present and eternal, may depend on the choices made. Paradise Lost contains the widest range of characters and situations requiring decisions and choices, but this poem will not be considered in any detail in my thesis, except for the Abdiel episode, which will be discussed in Chapter One.

Paradise Lost places its characters and their actions in an environment where direct or mediated access to the truth is possible, while marking the transition from that original created state to the state of being in history after the Fall. In this poem, only the fallen angels experience the full implications of being "in history." Raphael and Michael provide Adam and Eve with authoritative knowledge, and Abdiel finds full endorsement 
of his decisions when he returns to Heaven. Milton does not make the presence of such an authoritative, angelic narrator essential to his late two poems and that is because of his emphasis on being in history and the unavailability of such a narrator in history after the Fall, including for the Son of God and Samson, to present certain knowledge about the future. The future is to be found in the way demonstrated by the Son of God and Samson as they try to determine what is to come. Milton provides the starkest analysis of the human situation in his two late poems, because they focus completely on the process of making a decision in a specific time and place in history after the Fall, where there is no direct access to authoritative confirmation of one's decision. The principal characters of Paradise Regained and Samson Agonistes are in history whereas the characters of Paradise Lost are not. Milton and Derrida's conception of what constitutes the core of the possibility of democracy, a free decision made according to conscience, comes most strongly into view in this situation. Furthermore, based on the argument of my thesis, most of the characters in Paradise Lost cannot be considered fit readers because they fail the trial of the aporetic moment/space of decision and fail to make a true decision. Adam and Eve are singular examples whose poor decisions affect all human generations.

Moreover, Derrida's concept of the aporetic moment/space of decision provided a way of thinking about the two late poems as comparable and as having the same purpose, in contrast to much of the scholarship written on them. This different approach will address the interpretive problem in recent Milton criticism on Paradise Regained and Samson Agonistes by arguing that these poems entirely make the aporetic 
moment/space of decision their focal point. This debate in Milton criticism concerns how the sign of uncertainty or indeterminacy in Milton's thought, as manifested in his poetry and prose writings, is to be interpreted. The scholar who has most fully explored this dimension of Milton criticism is Peter Herman, whose recent publications locate his argument in relation to a dominant and long term orientation in Milton criticism, and which come to focus with particular force upon Milton's two late poems.

In his introduction to Destabilizing Milton: "Paradise Lost" and the Poetics of Incertitude, Herman asks these questions: "how the dominant mode of Milton criticism works, and how Milton criticism is finally starting to undergo fundamental changes" (3). He begins his response with Stanley Fish's position and his account of the phrase "interpretative community," which refers to how interpretations are predetermined and filtered by the (mostly unwritten) rules and principles of scholarly communities. According to Fish, Herman states, "interpretations always occur within communal situations and according to rules determined by the group, which will accept some interpretations as valid and not others. The regulatory agency determining interpretative validity, therefore, is not the text itself, but the interpretative community" (3). Fish argues that the prevailing and governing communities of scholars and scholarly institutions with their rules and expectations predetermine and pre-assign legitimate interpretations of a text. Therefore, "interpretations are not objectively discovering meanings embedded in a text that stands independent of interpretations" (5). Herman indicates that Fish himself was no exception and belonged to a Miltonist community including C. S. Lewis, Barbara Lewalski, and E. M. W. Tillyard. He argues that "the 
scholars whom Fish considers 'gods and demigods,' are the ones whose work has come to define both the content and the parameters of Milton studies" (7). He asks the fundamental question: "So what are the rules, borders, or parameters, for an acceptable piece of Milton criticism?" (7). His answer is:

The paradigm that has largely governed Milton studies until very recently, and which continues to hold great sway, consists of three propositions:

- Milton is a poet of absolute, unqualified certainty;

- Paradise Lost coheres;

- The critic's task is to make the poem cohere. (7)

A substantial number of distinguished Miltonists have supported and followed this paradigm, and there are still many of them today. No matter what a critic's focus is (Herman provides a list of critics with different perspectives, including the politicallyengaged Christopher Hill, the fundamentally apolitical Harold Bloom, the masculinist Mary Nyquist, the feminist Diane McColley, the proto-deconstructionist Herman Rapaport, or the theological Albert C. Labriola), their scholarly work "is generally carried on within specific boundaries" (8). He claims that different interpretive groups of Milton criticism have been always loyal to the "paradigm of Miltonic certainty" despite some sporadic acknowledgment of indeterminacies and contradictions in his works: "Incertitude and contradiction, confusion and vacillation, are incompatible with the paradigm of Miltonic certainty, which is not to say that the problems in Milton have gone entirely unnoticed" (10). 
Nevertheless, some critics have identified and argued for the presence of indeterminacy and the constantly shifting grounds of action in Milton's works. Herman gives an almost complete list of the authors who have identified anomalies and indeterminacies in Milton, but overall they have remained within the circle of those following the dominant paradigm of certitude. Herman argues that "Despite the promise of Balachandra Rajan's title, 'Paradise Lost. The Uncertain Epic,' this distinguished critic concludes by denying the presence of any uncertainty in the epic: 'If Paradise Lost is an uncertain epic, it is uncertain not because it is confused or vacillating, but because it is clear about how it must form itself"' (179, Herman's emphasis). Regina Schwartz in her book, Remembering and Rejecting: on Milton's Theology and Poetics, Herman argues, makes the removal of the contradiction in Milton's work "the main purpose of her work on this topic" (8). Furthermore, James G. Turner also sees Milton as "a heroic synthesizer of incompatible materials, continually engaged in the imaginative transcendence of conceptual limits" (9). Herman asserts that among the Milton critics interested in the political resonances of Paradise Lost, Christopher Hill and Mary Ann Radzinowicz, ${ }^{3}$ as two good examples, are "in perfect accord with each other on the matter of Miltonic certainty and the governing paradigm of Milton studies" (9). To him, Sharon Achinstein, in Milton and the Revolutionary Reader, similarly posits a Milton untouched by doubt, and David Loewenstein, in Representing Revolution, regards Milton's epic as certain and didactic, prompting its fit readers to "observe carefully the

\footnotetext{
${ }^{3}$ See Milton and the English Revolution and The Politics of Discourse. Herman also refers to Michael Lieb, in "The Dialectics of Creation," and William Kerrigan, in "The Sacred Complex" as two examples of critics who follow the paradigm of certitude in their interpretation of Milton's works.
} 
ambiguous, slippery uses of political rhetoric, including the uses of provocative republican discourse itself" (9). From Herman's perspective, Barbara Lewalski, in The Life of John Milton, equally supports the idea that even though some critics claimed that Milton's poem carries "ambiguous and seriously unsettling political messages [...] the poem does nothing of the sort" (9).

Nonetheless, Herman confirms that some Milton scholars have identified "anomalies" in Milton's works especially in Paradise Lost, but they ultimately came to defend the paradigm of certainty by adopting two strategies: suppression (complete refusal of the possibility of any Miltonic uncertainty) or showing that "the anomaly is not really an anomaly, if only properly understood" (11). He argues that:

Although, over the years many critics (including Bentley) have noticed that Paradise Lost constitutes, in Joseph Wittreich's phrase, “a field of opposing stresses and signals," the usual recourse is to try, as [Christopher] Ricks does, to resolve the issue one way or another. For example, although both A. J. A. Waldock and John Peter highlight the many discontinuities of Paradise Lost, they ascribe them a regrettable failure of poetic craftsmanship rather than trying to read the many incompatibilities as thematically meaningful. Dennis Burden (following both Pearce) argues that Paradise Lost is "an exercise in clarification, finding system and order in what could, if wrongly taken, appear to be random and inexplicable." (15, his emphasis) 
Therefore, to Herman, although "some very recent critics have started to foreground Milton's contradiction" (15), most frequently they have tried similarly to find a way "to eliminate the 'apparent conflict' between incertitude and the dominant paradigm of Milton studies through the principle of discordia concors" (15, his emphasis). ${ }^{4} \mathrm{He}$ asserts that even Joseph Wittreich who has done "more to analyze the contradictions of Paradise Lost (and Samson Agonistes) than anyone else, has similarly subverted the poem's conflicting signals by analogizing Paradise Lost to A. Bartlett Giamatti's ideal university - a place where 'competing systems of thought collide; where they are 'tested, debated [...] freely, openly.""5 According to Herman, Stanley Fish, in How Milton Works, argues similarly that many moments in Paradise Lost and, in particular, Samson Agonistes are "marked by a radical openness and indeterminacy." Fish gives the evidence that he pursues the paradigm, Herman asserts, when he indicates that "there may be a way of thinking about [Milton's] project that accommodates and even reconciles its diverse impulses" (500).Close to the end of his introduction, Herman repeats the point of his argument that "The governing paradigm of Milton criticism Milton as poet of certainty - has, as I hope I have proved, very wide, very deep roots, and it has stayed remarkably stable over time" (19). Nevertheless, he argues, change has finally come to Milton studies and "the paradigm governing Milton studies is shifting"

\footnotetext{
${ }^{4}$ As examples, he refers to some Milton criticism: Steven Jablonski's Arenas of Conflict, William Kolbrener's "Milton's Warring Angels," David Norbrook's Writing the English Republic: Poetry, Rhetoric and Politics 1627-1660, and Dennis Danielson's "Milton's Theodicy."

${ }^{5}$ See Joseph Wittreich, "He Ever was a Dissenter," in Arenas of Conflicts, quoting A. Barllett Giaman, $A$ Free and Ordained Space, pages 29-30.
} 
(20). He lists the names of writers responsible for this change ${ }^{6}$ and asserts that this group's approach to Milton criticism is fundamentally different. Herman promises "to further this paradigm shift by proposing that Milton is, in fact, a poet of incertitude, and this condition, I further propose, results in large part from the failure of the English Revolution" (21, his emphasis). In his book, he indicates that a Miltonist like John Rumrich, in Milton Unbounded, has argued for "the shaping presence of 'indeterminacy and differences of opinion' in Paradise Lost saying, that he finds 'the theme of indeterminacy as a vital dimension of human experience and behaviour.' Indeterminacy is thus a positive state of creative flux; if certainty is deferred, the jouissance of infinite possibility takes its place" (21, his emphasis). Herman replaces Rumrich's term "indeterminacy" with "incertitude" because he believes that:

$[\ldots]$ in the aftermath of the Revolution, the critical sensibility that Milton championed throughout his career led him to engage in a wholesale questioning of just about everything he had argued for in his earlier prose works, and he does not come to a conclusion. Therefore in place of Rumrich's 'poetics of becoming,' I propose a poetics of incertitude because it is out of the turmoil of not knowing what to affirm in the work of the Revolution's failure that Milton creates some of his finest poetry. (21, his emphasis)

\footnotetext{
${ }^{6}$ Michael Bryson, Stephen Dobranski, Neil Forsyth, William Kolbrener, Ronald Levao, Cathrine Gimell Matin, David Norbrook, John Rogers, John Rumrich, Richard Strier, Elizabeth Sauer, Jeffrey Shoulson, and Shari Zimmaerman, among others. (79)
} 
The argument of my thesis will challenge Herman's position and other new Milton critics. $^{7}$ I will be arguing that - without denying the existence of "interpretive communities" and the paradigm of certainty of Milton criticism in some Milton criticism - that Milton is certain enough to tell us that as fit readers we must go through the indeterminacies and uncertainties of the moment/space of decision to make a true decision grounded in each individual's self-authorization. Milton certainly knows about the conflicts, contradictions, and uncertainties of human life on earth after the Fall. He believes that we are living in a world of good and evil with our fallen minds; he knows that truth and justice will not be completely available to us until the Second Coming. Nonetheless, he also believes in human reason and the possibility that, with divine assistance, human societies can make life better and much endurable. Milton is positive about the capability of humans to become fit readers and the possibilities they can open up for their societies through their decisions and actions. He is certain that it is only out of indeterminacies, uncertainties, and contradictions in the human situation in history that we, as fit readers, are able to bring some good, truth, and justice to our life. Milton demands that we become fit readers by developing capabilities essential for making true and just decisions. His attempt, in his works, is not to present us with an absolute model of behaviour and decision-making. In fact, he does not believe in fixed, absolute models and patterns blindly used by unfit readers, "bad men," in different situations and cases. He believes in the absolute singularity of the moment/space of decision-making, which requires singular treatment and action. There is always a different singular model of behaviour for every case. Milton's thought about how to become a fit reader is the

\footnotetext{
${ }^{7}$ Like Michael Bryson and Joseph Wittreich.
} 
fundamental element of his works, something that we encounter throughout his works, both in prose and poetry.

Herman argues that Milton wrote Paradise Lost as a poem that refuses to give its readers any interpretive certainty or stability because after the failure of the revolution he questions every certainty he argued for in his prose works. On the contrary, I will be arguing that Milton's intention in his works both prose and poetry, and especially Paradise Regained and Samson Agonistes, was not to give us any "interpretive certainty" because he did not believe in fixed interpretive models that can work like tyrannical powers on our reading. In Milton's thought, fit readers should not accept preprogrammed, predefined, and predetermined models of reading. I will be arguing that Milton's representation of indeterminate, uncertain situations and events in his works is not because of his uncertain state of mind, but because he is concerned to engage his readers in experiencing the requirements and capabilities of reading for the sake of truth and justice. ${ }^{8}$

In his book, Peter Herman argues that Milton's epic similes and metaphors lead us (readers) to a point of aporia. He claims that such a "metaphoric incertitude" reflects Milton's unsettled state of mind after the collapse of the revolution. Towards the end of his discussion on Paradise Lost, he explains the condition of the reader of Milton's work:

\footnotetext{
${ }^{8}$ In chapter 2 of his book, Herman argues that Paradise Lost is not a poem of perfect unity, and that, after the collapse of the Republic, Milton uses the "poetics of incertitude" in this poem to demonstrate his own uncertain state of mind.
} 
The Miltonic "Or," therefore, inscribes incertitude at the heart of Paradise Lost. Just as Milton explicitly scatters "or" throughout his poem, often offering the reader choices between opposites that he declines to settle, so does he implicitly situate an "or" between the differing narratives of the poem's central events. Just as Milton presents the reader with an explicit choice between Satan as Typhon or Satan as Briareos, between Eve's gardening tools coming from an Angel or from rude art, and between Satan as a hungry wolf or as a greedy thief, he also presents the reader with an implicit Miltonic "Or" between radically different narratives of the poem's most important events, and the reader does not know, cannot know, which, if any, is the accurate version. (57, his emphasis)

If readers expect Milton's works to provide them with authoritative interpretations, they will be disappointed because Milton does not aim to present his readers with predetermined, ready-made answers and models for action. Herman neglects the fact that Milton is addressing fit readers who are few but fit. Accordingly, a fit reader of Paradise Lost must demonstrate the ability to examine all these choices and individually determine the truth. If Milton presents the most important events of his poem with some explicit or implicit "Or," I will argue, it is not that he is uncertain about them. The reason is that Milton believes that the individual experience of such radically indeterminate moments is indispensible for a fit reader and it is only through this that one can develop and demonstrate the qualities of a fit reader. 
The fit reader for Milton is one who must decide by experiencing the uncertainties and indeterminacies of aporetic moments/spaces of decision-making. Milton exemplifies the problematic and revolutionary conditions of such moments through his portrayal of different characters at some radical moment/space of decision; namely, Abdiel and Satan, Eve and Satan, Adam and Eve and Satan in Paradise Lost, the Son of God and Satan in Paradise Regained, Samson and Manoa, Dalila and others in Samson Agonistes. The demonstration of these moments is not due to his uncertain state of mind, but because of the very specifics of the aporetic moment/space of decisionmaking. Milton shows us how difficult it is to be in such a situation, and reminds us that there is no singular formula or model of behaviour, which can be applied to all such uncertain moments. He indicates that it is only through the individual experience of the singular moment/space of decision that one might be able to make a true decision.

Milton's works represent the aporetic moment/space of decision as a constant potential in experience; it is a singular moment in which uncertainties and indeterminacies produce irresolvable choices, but where a decision must, nonetheless, be made; it is a moment of trial the result of which cannot be known to anyone in advance, even the individual fit reader. Milton's late poems, Paradise Regained and Samson Agonistes, explore the critical significance of this moment and demonstrate that no certain, fixed, pre-programmed, or predetermined model or frame can be applied to the resolution of aporetic moments of decision in different times, places, and contexts. The fit reader is one who radically and critically reads and re-reads aporetic situations as pregnant with inescapable indeterminacies and unresolved choices, and who expresses his individual 
judgment in the singular form of a responsible, true decision and its enactment. For Milton, this moment is a radically individual and problematic moment, which goes beyond the usual private/public space even though the public aspects and responsibilities of the person's decision demonstrate exceptional significance in the form of public enactment. I will argue that Milton always wrote with the desire to highlight and exemplify the absolute singularity of such a moment and its experience throughout his life and works, both prose and poetry.

I will also argue that, against the contention of the new Milton critics that Milton is a confused and uncertain poet at the time of writing his poetic works after the Restoration, Rumrich's term "indeterminacy" needs to be used again in company with Derrida's notion of the to-come. I will use the phrase "the poetics of the to-come" instead for Milton's works arguing that Milton was not confused after the demise of the revolution and he was not writing in an uncertain state of mind. He was always conscious about what calls forth justice, truth, freedom, humanity, and democracy. He had hopes for the performativity of a writing that acts in this direction, most specifically a grand poetic work. He was certain about this desire or responsibility throughout his lifework, although uncertainties, contradictions, and indeterminacies appear in his works, both prose and poetry. I think Milton believed that there is no singular example or pattern to be used in all the cases we encounter in our life. This is what creates a unity or continuity in his works both prose and poetry. All things in the world are singular examples and need immediate and separate consideration. There is no exemplarity for Milton and no single treatment of the problems in the world. We must 
act as fit readers in considering all events as singular, like singular books that can always be re-read differently and judged differently.

Therefore, instead of demonstrating that Milton persistently endeavours to define truth and justice and deliver his thoughts on them as fully fixed frameworks offering ultimate solutions for the problems of living in the world, we must argue that he is constantly throwing his readers into multiple, undetermined, and uncertain states of affairs in which the process of articulating truth remains endlessly complicated and constantly imperfect. Milton makes his utmost attempt to avoid presenting the fundamental questions in a simple white-black and problem-solving manner. The element of indeterminacy has to do with the horizon of the future or the to-come in a way that is open to the unknown, which is truth, justice, freedom, humanity, and democracy to come. The work of the thesis is to explore a deep connection in the development of Western humanism by demonstrating the close affiliation that exists between Milton and Derrida as two leading exponents of that humanistic tradition of thought. It will explore a mutually interpretive relationship between Derrida and Milton, through the interaction between various prose texts of both authors. Derrida provides me with critical terms, which allow for a differently inflected reading of Milton's purposes in his works. Therefore, Derrida provides me with the language of the discussions in the opening chapters. The aim of the juxtaposition in connection to similar concepts in their thought is the demonstration of critical aspects of Milton's thinking through Derrida's language not available to Milton and his time. 
The thesis will represent its arguments in two sections. The first section (the opening five chapters) will explore and identify possible continuities and convergences between the two writers through a reading of Milton and Derrida's arguments in their prose texts. The second part of the thesis consists of two chapters in which I will present my readings of Paradise Regained and Samson Agonistes, as singular examples of Milton's manifestation of the notions of fit reader, aporetic moment/space of decision, and poetics of the to-come.

The task of the first five chapters of the thesis will be to discuss the way the fit reader/democratic intellect responds to fundamental questions of singularity, exemplarity, public space without condition, deconstructible law and undeconstructible justice, the critique of violence, and literature as a radical institution. The overall meaning of the notion of the aporetic moment/space of decision is determined by these concepts. In these chapters, the thesis seeks to engage in an exploration of Derrida's and Milton's prose works to demonstrate the similarities and affinities in their thought on the qualities of the fit reader/democratic intellect expressed in the process of making a true and just decision. The argument in each chapter establishes the qualities and attributes of the fit reader/democratic intellect. I will be arguing that to become a fit reader/democratic intellect one needs to experience the aporetic moment/space of decision in order to develop certain critical capabilities and abilities. This aporetic moment/space of decision will be always singular in each case and in different contexts, times, and places. It is a moment of uncertainties and indeterminacies in which all established laws, principles, and norms known to a society and its individual members 
are fundamentally suspended, questioned, and redefined by the fit reader/democratic reader. The experience of such a moment/space of decision is indispensible for Milton's fit reader and Derrida's democratic intellect. In their radical critique, a fit reader/democratic reader demonstrates the notion of the to-come by carrying out a deconstruction of the fundamental concepts and themes of the systems of thought and powers of their time and society. The decision made within such an aporetic moment/space leads to a singular action unfamiliar and unavailable to the established systems and institutions of society. The focus of the opening chapters is the placing of the individual in a moment of decision leading to an action in a public space that would change the quality of that public space. The prose texts examined in these chapters are presented as examples of the poetics of the to-come because they partly foreshadow the conceptions and conditions on which a better human society - democracy or humanity to come - may be developed.

In Chapter One, I will focus on the question of singularity in Milton's Paradise Lost and Derrida's essay, "The Laws of Reflection," in For Nelson Mandela. Milton demonstrates a lifelong concern with the question of idolatry, martyrdom, and iconoclasm in his works, the crucial question to which his fit reader must attend as well. The task of a fit reader is to identify the "false" from the "true" martyr, which is possible only when the problem is approached radically, critically and freely. Singular figures evoke either our admiration like Nelson Mandela and Abdiel or our iconoclastic approach like King Charles I. In the Abdiel episode in Paradise Lost, Milton demonstrates the significance of the process of reasoning and choosing (deciding). I will argue that Milton warns us 
(his fit readers) about the possibility of the idolization of admirable figures like Abdiel. Although Abdiel is depicted as an admirable and singular example, he should be by no means considered, in Milton's thought, exemplary.

In Chapter Two, I will attend to the question of public space without conditions and the institutional guarantor of such a democratic space in Milton's Areopagitica and Derrida's essay, "The Future of the Profession," in Derrida Downunder. My argument in this chapter will support Areopagitica's privileged position "as the great treatise on freedom of the press" by focusing on the importance of public space. In Areopagitica, Milton addresses the question of public space without conditions and emphasizes its indispensability for society and individuals (fit readers) by defending the free operation of critical intellectual work for the revelation of truth. Milton's main concern is to underline the necessity of the ongoing search for the revelation of truth through free radical reading, writing, and intellectual work assured by an unconditional public space. Derrida similarly accounts for the indispensible unconditionality of a public space for the radical critique of a fit reader/democratic intellect to happen. For both authors, although true critique and intellectual work happens in the most private and mental space of individuals' minds, a free public space to achieve and demonstrate its performativity as a public act for the sake of more revelation of truth and humanity to come remains indispensible. The institutional guarantor is "the parliament" for Milton and "the university" for Derrida. The more unconditional a public space is, the truer the decision-making process will be. 
In Chapter Three, I will attend to the question of law and justice and their relations and distinctions in Milton's Eikonoklastes and Derrida's essay, "Force of Law," in Acts of Religion. In Eikonoklastes, Milton practically demonstrates the method of reading required of those who would become fit readers. Like Derrida, Milton considers the law as deconstructible and justice as undeconstructible. A fit reader/democratic intellect must experience the interval between law and justice in order to make a just decision. Milton's model of reading, I will argue, is a radically critical and free reading that deconstructs the law to open up the way for the advent of undeconstructible justice. For Milton's fit reader, the experience of the problematic moment/space between law and justice at the time of decision becomes crucially vital; a symbolic trial out of which a fit reader must reason and choose truly and justly.

In Chapter Four, I will attend the question of the critique of violence in Milton's The Tenure of Kings and Magistracies, and the second section of Derrida's essay, "Force of Law" in Acts of Religion. Derrida argues that elimination of violence within laws is impossible due to their homogeneity. There is always, he asserts, violence in the very founding moment of law. In a revolutionary moment/space, the reality of the problematic relationship between law, justice, and violence becomes discernible and palpable. This aporetic moment of suspense is fundamentally threatening and deconstructive, a time during which established law is radically critiqued and suspended and is led to the introduction of a new law. The true critique of violence, Derrida argues, is only possible within such an aporetic moment/space that falls outside of the existing systems and structures. In The Tenure, Milton argues that putting the King on 
trial was the people's absolute right and his execution the very practice of the "sword of justice." He argues for the indispensability of the radical critique of rulers (arbitrary tyrants) that misuse their power and the force of law by turning it into violence against their people. To demonstrate this absolute necessity, he accounts for the potentiality of authorities to turn into tyrants. Such a possibility of violence is inherent within any system of government because of the desire of rulers to monopolize the force of law for their private aims and interests. People can reclaim the power given to their authorities whenever necessary. This situation produces a time of crisis within which the law or the system of government is fundamentally questioned and suspended. I will argue that Milton's focus in the two editions of The Tenure is on the revolutionary moment/space of suspense and the necessity that fit readers should experience such a moment.

In Chapter Five, I will use the concept of the poetics of the to-come to demonstrate the distinctive characteristics of Milton's poetics in the light of Derrida's concept of literature in Acts of Literature. I will argue that the kind of poetry Milton appreciates and is willing to perform is even unpredictable and unknown to him. Poetry demonstrates itself as something that he wishes for, something that the already developed institutional categories are unable to include or appropriate, something that remains to come. Milton uses the term "poetry" in a way that resonates with characteristics Derrida identifies in relation to the modern term "literature" as an institution. With this identification, Milton's poetics would include his controversial publications, both prose and poetry, under the same category. The desire for justice and truth, the desire for a public, democratic institution in which one can say everything, the 
desire for an institution that makes radically critical readings of social-political powers possible by means of performative acts of writing, constitute the common ground for Milton's conception of poetry and Derrida's notion of literature. For Milton, the question of the poetics of his works presents itself to his readers in the very moment of radically critical and free reading when the authority of his texts is suspended and reaffirmed. In this sense, his poetry is in the form of the to-come, waiting for the act of reading to take place. His poetry comes into existence whenever a fit reader experiences the aporetic moment/space of decision in relation to his writings, both prose and poetry.

The exploration of the texts in the opening chapters foreshadow the concepts and conditions on which a better human society may be developed by locating an individual in the aporetic moment/space of decision, leading to a public act to introduce changes into the quality of public space. The arguments promisingly delivered the essential terminology to formulate a new understanding of Milton's writings. The second part of the thesis will apply these themes to Milton's short poems, Paradise Regained and Samson Agonistes. The purpose of Chapter Six and Seven is to demonstrate the common features of the aporetic moment/space of decision and the notion of the poetics of the to-come in these short poems. The crucial conception is that the poems intensively develop the uniqueness and singularity of the aporetic moment/space of decision, and at the same time, identify the generality of the characteristics of this unique moment/space. I will argue that Paradise Regained and Samson Agonistes provide singular exemplifications of Milton's notion of the fit reader, with similar qualities and attributes to Derrida's democratic intellect. 
Derrida's concept of the aporetic moment/space of decision provides a different way of thinking about the two late poems as comparable and as having the same purpose, in contrast to much of the scholarship written on them. My approach will address the interpretive problem in recent Milton criticism on the short late poems: how the sign of uncertainty or indeterminacy in Milton's thought is to be interpreted in them. I will argue that the qualities Milton is attaching to the notion of fit reader in his prose works are exhaustively gathered up and exemplified in these poems. The poetics of the tocome is Milton's dominant perspective by which he demonstrates the attributes and qualities of his fit reader. These qualities must be developed through experiencing an aporetic moment/space of decision, which provides the basis for a true decision for the sake of some possible truth, justice, democracy, or humanity to come. 
Chapter One

\section{The Question of Exemplarity and Singular Examples}

In this chapter, the question of singularity will be discussed as a crucial continuity in Milton and Derrida's thought. The Abdiel episode in Paradise Lost and Derrida's discussion of Nelson Mandela in his essay "The Law of Reflection," in For Nelson Mandela, will be discussed to show that both thinkers reject exemplarity in favour of singularity. Abdiel and Mandela are fit readers/democratic intellects because of their method of radical critique, the principles of which are not available to any individual in the form of definitive models or procedures. Milton, like Derrida, warns us that there is no absolute example able to provide a definitive model for decision and action. All singular examples (like, Abdiel, Mandela, the Son of God, Samson) are admirable figures but not exemplary.

In his works, John Milton demonstrates a lifelong concern with the question of idolatry, martyrdom, and iconoclasm. The notion of fit reader/audience is a crucial preoccupation because only a radically critical and free reading is capable of distinguishing between admirable figures (like Abdiel) and false martyrs like Charles I. Milton scholars have noted his engagement with the question of idolising martyrs in his tracts, Eikonoklastes and The Tenure of Kings and Magistrates. ${ }^{9}$ However, Milton criticism, as Margaret

\footnotetext{
${ }^{9}$ For Milton's iconoclastic purpose in Eikonoklastes, see Laura Lunger Knopper's Historicizing Milton, especially pages 4 and 27; Florence Sandler "Icon and Iconoclast," in Achievements of the Left Hand,
} 
Justice Dean argues, ${ }^{10}$ has not "yet noted the prominence of this issue in Paradise Lost" (227). ${ }^{11}$ How is the "false" martyr to be discerned from the "true" ones? This question constantly addresses itself to Milton's fit reader who, through their radically critical reading of exemplary figures, develops the essential fitness, qualities, and attributes to make a just judgment and decision. Nevertheless, exemplary figures present themselves to us in two groups; those who evoke our admiration like Nelson Mandela and Abdiel and those who necessitate our iconoclastic approach. My argument in this chapter is that Milton warns us (and fit readers) about the possibility of the idolization of admirable figures like Abdiel. ${ }^{12}$ Although Abdiel is depicted in Paradise Lost as admirable, in Milton's terms he is a singular example and should by no means be considered as exemplary.

To elucidate my contention, I will first attend to the way Derrida is thinking about the question of singularity and exemplarity in relation to Nelson Mandela. In "The Laws of Reflection," Derrida presents his argument on the question of singularity and singular examples - "exemplary witnesses," as he calls them. He addresses two main questions in terms of Nelson Mandela's life and experience: what true admiration is, or how we

especially pages 160-84; Achsah Guibbory "Charles's Prayers" in Of Poetry and Politics: New Essays on Milton and His World.

${ }^{10}$ See Margaret Justice Dean's essay, "Martyrdom reconsidered," in Milton in France. In this essay, Dean focuses on the links between "Milton's definition of martyrdom from De Doctrina Christina with his depiction of Abdiel and his discussions of false martyrs, such as Charles I and Mary Queen of Scots, with Adam" (227).

${ }^{11}$ See also John R. Knott's Discourses of Martyrdom, and Laura Lunger Knoppers's Historicizing Milton.

${ }^{12}$ In chapter three, attending Milton's iconoclastic approach in Eikonoklastes, I will be arguing that Milton exemplifies the radically critical and free reading of his fit reader through a deconstructive reading of King Charles's book, Eikon Basilike. 
should admire or respect Mandela; and, why we admire him, or what he has done that forces us to admire him. Derrida argues that we admire Mandela because of his own singular act of admiration which is the outcome of his radical and critical reflection and analysis. His reflection is a practice of both contemplation and reflection in the sense of mirroring and casting light on some institutionally blurred and unreadable situations or issues. Mandela as a democratic subject stands against the state and its laws, questioning the whole legitimacy of the apartheid government and choosing a law, which he calls the law of conscience, or the law of laws. He presents his self in the voice of conscience through his radically critical and free approach to the law of the state. This radical critique is a true response to his profession and his duties as a lawyer. The radical reading makes visible the institutional unreadability of the apartheid legal system. Derrida argues that the singularity of Mandela's critique and experience depends on the irreducible social, political, cultural, and contextual specifics of his life. We must respect Mandela, Derrida writes, "in his irreplaceable singularity," which is not exemplary. In other words, Derrida reminds us that our admiration of admirable people like Nelson Mandela should not lead to their idolization, making them absolute exemplary figures and models. We must instead respect and pay attention to his radically critical examination of the violent apartheid legal system, through which he aims to bring justice to his people and humanity. Mandela's critique is in direction of justice, democracy, or humanity that is not yet in place.

Derrida's argument will help us to understand Milton's representation of lapsarian and prelapsarian figures ("one just man" or fit reader) like the Seraph Abdiel. I will argue 
that not only, like Derrida, does Milton explore the questions and issues located by Derrida in the terms of singularity, exemplarity, and singular examples, but also he demonstrates a similar understanding of those questions and issues. Milton has exemplified his request in the question of exemplarity throughout his works, both prose and poetry, but I will consider one of the singular figures of Paradise Lost, Abdiel and his unique experience, for my discussion. Like Derrida, Milton emphasizes the singularity and exemplarity of Abdiel's experience and the appropriateness of admiring him on the grounds of his radically critical and free reflection of his situation and his individual decision. He opposes Satan by responding to his "right reason," the law inside him, "God's Law." Milton demonstrates the significance of the process of reasoning and choosing in Abdiel's case; his experience is narrated for Adam and Eve not because it must be imitated as a fixed model as Satan's possible attack or temptation occurs, but because it emphasizes the process of radical critique, reasoning and choosing in different contexts. ${ }^{13}$

\section{Double Genitive Admiration}

Derrida represents his argumentation of the question of admiration, reflection, and exemplarity through accounting for Mandela's singular case. In "The Law of

\footnotetext{
${ }^{13}$ See Tung Mason's essay, "The Abdiel Episode: A Contextual Reading," in which he argues that the Abdiel's "lone opposition was undertaken under more difficult circumstances than either those of Eve" and that "Adam and Eve had sufficient strength in themselves to desist and abstain [...] The most important proof of the evitability of the Fall is of course Abdiel" (606).
} 
Reflection," he starts with the questions, "How can one be Mandela?" (13), and how is one able to urge others to admire him? Nelson Mandela is one of the most prominent examples of people who have become the subject of universal "honour" and "admiration." From the very outset, Derrida insists that he will not write in Mandela's honour but about Mandela' honour, promising not to succumb "if possible, to loftiness." Derrida proclaims that he intentionally does not use an exclamation mark when addressing Mandela: “Admirable Mandela. Period, no exclamation point" (13). There is something about Mandela that incites, impels admiration and in fact enforces us - even "his most hateful persecutors" (13) - to admire him and his actions. Derrida suggests the term "homage" instead of "admiration" because there is a sense of analysis in it "without proclaiming or acclaiming" (13). The reason for his conservative use of terms and punctuation in appreciation of this unique contemporary figure provides us with the key idea in the question of exemplarity. He admires Nelson Mandela but does not want him to be promoted as exemplary. He urges his readers to differentiate between honouring an individual and boosting him to the status of a consecrated model. Any example is just a singular example, not exemplary. He accounts for the term "admiration" as follows:

Admiration reasons, whatever is said of it, it works things out with reason, it astonishes and interrogates: how can one be Mandela? Why does he seem exemplary and admirable in what he thinks and says, in what he does or in what he suffers? Admirable in himself, as well as in what he conveys as a 
witness, another word for martyrdom, that is to say the experience of his people? (13)

Admiration, Derrida indicates, has some force and Mandela forces us to admire him primarily because the force of admiration has "the line of a reflection" (14, his emphasis) in it. The above lines highlight a force of analysis and "reason" in "admiration." Mandela "like all the greatest politicians, is a man of reflection," Derrida argues, enjoying the advantages of a "theoretical reflection: about history, culture, and above all jurisprudence" and a "rationality" (14) in support of his political experience or passion. There is light in reflection. Reflection cannot be blind. It is full of thought, reason, and rationality. In other words, rationality or contemplation is a force possessed by admirable figures like Nelson Mandela. Their thought and reason casts light on blurred issues like the relations between an individual and the state. When there is light, injustice cannot easily loom around and haunt the mind. In the light of reflection, the camp of evil and injustice seeks a place to hide rather than sell its veils.

There is also a sense of mirroring in the term "reflection" that is related to the illuminating power of light. Direct light, more than illuminating, tends to blind. Reflected light, on the contrary, is not blinding and it does the significant work of clarification and elucidation. The force of reflection is to turn back the violent darkening light of a system over it so that it becomes visible and readable enough to be identified and analysed in depth. Admiration, Derrida declares, "always enables us to see $[\ldots]$ enables understanding. Outside of it there is only ignorance" (14, his 
emphasis). Mandela has this mirroring effect on the Apartheid Regime and its corrupted laws. He illuminates the violence and injustices of the white-governed system. This is Mandela's passion. Mandela forces us to admire him because he reflects the blinding light of the violent apartheid system back onto it and makes its violence, injustice, and illegitimacy visible to the South Africans and even the people inside the government.

The logic of reflection is inflexible and does not bend to any power or force in society. Derrida refers to two examples as the signs of Mandela's practice of the inflexible logic of reflection. First, he mirrors the violence of the establishment of the constitutional law in South Africa as a "coup de force" but "this violent act at once produced and presupposed the unity of a nation" (17, his emphasis). Mandela insists that because the unity of a nation had never become a reality, the law never managed to establish itself in that state. It was betrayed from the very beginning by the "white minority" and their supposedly South African Republic. In fact, the founding violence of the establishment of the white government in South Africa "remains at once excessive and powerless, insufficient in its result, lost in its own contradiction" and "must repeat itself indefinitely" (18). The constitution of the state did not have the support of the "popular will." In Derrida's words, the critique of violence is possible only if a force challenges the violence of the law from outside of the system. ${ }^{14}$ Mandela understands that remaining within the frame of the state apparatus will not let the logic of reflection demonstrate the true nature of the government. Derrida states that Mandela "thus contests the authority, the legality, the constitutionality of the Constitution. He thus

\footnotetext{
${ }^{14}$ See my discussion on the critique of violence in Chapter Four.
} 
refuses the proposal of - and the alliance with - the white liberals who would struggle against apartheid even as they claim to respect the legal framework" (19).

The second sign of Mandela's practice of the inflexible logic of reflection is his admiration of the model of traditional South African society. His reflection in this regard remains inflexible because he does not surrender to imagining any completeness for his ancestors' democratic tribal system; however, he remembers them and is indeed fascinated by them. Mandela argues that "There was much in such a society that was primitive and insecure and it certainly could never measure up to the demands of the present epoch. But in such a society are contained the seeds of a revolutionary democracy in which none will be held in slavery or servitude, and in which poverty, want, and insecurity shall be no more [...]" (24, his emphasis). In terms of the question of singularity, the imperative here is that Mandela critically and radically reviews the available knowledge and examples of social-political systems, but does not limit his critique to adopting an existing model as fully exemplary. He longs for a classless society and the end of the exploitation of man-by-man. Derrida asserts:

Mandela is fascinated by what he sees being reflected in advance, what is not yet to be seen, what he fore-sees: the really revolutionary democracy of which the Anglo-American West would, in sum, have only given an image at once incomplete, formal, and thus also potential. Potentiality against potentiality, power against power. For if he "admires" the parliamentary systems of the most Western West, he also declares his "admiration," and it 
is still his word, still the same one, for the structure and organization of early African societies in this country. (25)

\section{Radical Critique of the Law and Response to the Voice of Conscience}

Derrida argues that Mandela's admiration is both given by him and given to him. He knows how to admire and this is what generates our admiration of him. Mandela's admiration derives from his ability to know how to admire:

Admiration of Nelson Mandela, as we might say Nelson Mandela's passion. Admiration of Mandela, a double genitive: the one he inspires and the one he feels. The two have the same focus, they reflect upon each other. I have already stated my hypothesis: he [Mandela] becomes admirable for having, with all his force, admired, and for having made a force of his admiration, a combative, untreatable, and irreducible power. The law itself, the law above other laws.

For in fact what has he admired? In one word: the Law. And what inscribes it in discourse, in history, in the institution is jurisprudence. (15, emphasis added)

Though being convicted and imprisoned, Nelson Mandela emphatically proclaims that he admires the law. In doing this, Mandela positions himself in a unique way and in terms of his relation to the state and its laws. Mandela admires the law, but is this law, 
which gives orders to constitutions and declarations, essentially the law of the West? Does the formal universality of law retain some irreducible link with European or even Anglo-American history? Derrida responds to these questions by quoting Mandela and identifying him as an admirer of the parliamentary system of the West, the Magna Charta, the Petition of Rights, the Bill of Rights, and the British Parliament and its judiciary. He argues:

[...] what Mandela admires and says he admires is the tradition inaugurated by the Magna Charta, the Universal Declaration of the Rights of Man under their diverse forms (he frequently calls upon "human dignity," upon what is human and "worthy of that name"); it's also parliamentary democracy and, still more precisely, the doctrine of the separation of powers, the independence of justice. (16-7)

Considering Mandela's position here, the question of singularity becomes crucial. Although he is the admirer of the democratic, parliamentary system of government as it has evolved over time, of the law in the world of his time, he considers none of them as exemplary. He considers himself an inheritor of that evolution who does not merely "conserve and reproduce" the system. By the force of reflection, he uses the law against its practitioners and guardians in a different context (South Africa) and seeks a more complete expression of the law. Derrida argues: 
You can recognize an authentic inheritor in the one who conserves and reproduces, but also in the one who respects the logic of the legacy enough to turn it upon occasion against those who claim to be its guardians, enough to reveal, despite and against the usurpers, what has never yet been seen in the inheritance: enough to give birth, by the unheard-of act of a reflection, to what had never seen the light of day. (17, his emphasis)

Derrida indicates that for Mandela, it is not just the parliamentary democracy of the West "whose principle would be presented in the West as an example but not exemplarily" (25, his emphasis). Mandela considers the established laws and legal systems as singular examples but definitely not exemplary. He persistently conceives of the law in relation to the future; he is fascinated by the "prospective future" of a free "classless" society. His fascination with the law belongs to the invisible law of a society that is yet to come. Derrida argues that this law, calling out for Mandela's admiration, is not reducible to any representation in "objective space:"

[...] there would be no importation, no simply assignable origin for the history of law, only a reflecting apparatus, with projections of images, inversions of paths, interior duplications, and effects of history for a law whose structure and whose "history" consist in taking away the origin. Such an apparatus, and by this word I only mean that this $\mathrm{x}$ is not natural $[\ldots]$ cannot be represented in objective space. (22) 
There are two reasons for this lack of representation of the law in "objective space." The first reason is that the structure of the law "tends towards universality," whatever its historical context. The law of the minority white government in South Africa does not present the "essence" of the law from which it claims its authenticity. Derrida asserts that the South African government "is privatizing them [principles and laws of the West] particularizing them, appropriating them, and in that way taking them over against their very reason for being, against reason itself” (22). Mandela's reflection makes this process visible:

Whereas, in the struggle against apartheid, the "reflection" of which we are speaking here would make visible what was not even visible any longer in the political phenomenality dominated by the whites. It would oblige us to see what was no longer seen or was not yet to be seen. It tries to open the eyes of the whites; it does not reproduce the visible, it produces it. This reflection makes visible a law that in truth it does more than reflect, because this law, in its phenomenon, was invisible - has become or continued to be invisible. (22-3)

The second reason is that Mandela by his reflection upon the law "projects, reflects without seeing the very presence of this law in the interior of African society" (23). In other words, he admires in reflection the democratic principles of the African primitive tribes. Mandela states that in "the good old days, before the arrival of the white man," in South Africa, "there were no classes, no rich or poor, and no exploitation of man by 
man. All men were free and equal and this was the foundation of government" $(24$, his emphasis).

Derrida argues that Mandela is a man of law in all senses of the word and he has always appealed to the law. In presenting his "defiance" before the judges in the court, Mandela in fact rereads an indictment to condemn his prosecutors in the name of an "I" that "establishes himself and justifies himself, reasons and signs in the name of "we"" (26). Mandela confirms his defiance of the law because between the law of the state and his conscience he has chosen the latter. In fact, he believes that the law he has chosen is superior and nobler than the law of the state:

He presents himself in his people, before the law. Before a law he rejects, beyond any doubt, but which he rejects in the name of a superior law, the very one he declares to admire and before which he agrees to appear. In such a presentation of the self, he justifies himself in resuming his history, which he reflects in a single centre, a single and double centre, his history and that of his people [...] The presentation of the self is not in the service of the law, it is not a means. The unfolding of this history is a justification, it is possible and has meaning only before the law. He is only what he is, he, Nelson Mandela, he and his people, he has presence only in this movement of justice. (27, his emphasis) 
Derrida argues that Mandela takes "humanity as a whole" as his witness, and "he addresses himself to the universal justice above his judges" (27). We hear a voice in him, Derrida argues:

[...] hearing a voice, which never ceases to appeal to the voice of conscience, to the immediate and unfailing sentiment of justice, to this law of laws that speaks in us before us, because it is inscribed within our heart. In the same tradition, it is also the place of a categorical imperative, of a morality incommensurate with the conditional hypotheses and strategies of self-interest, as it is with the figures of such-and-such civil law. (27-8, his emphasis)

Mandela states that the apartheid government has put them in a condition that requires them to "choose between compliance with the law and compliance with our consciences" (28). He chooses the latter: "in such a dilemma, men of honesty, men of purpose, and men of public morality and of conscience only have one answer. They must follow the dictate of their conscience irrespective of the consequences which might overtake them for it" (28). The voice of the conscience, Mandela refers to, ranks before any law or any rules, Derrida argues. It is justice or the present irreducible energy that calls for one to defy laws in the name of the law. This law is the law of laws which "resides in the most intimate conscience, we must in the final instance judge intentions and goodwill, and so on. Before any juridical or political discourse, before 
the texts of positive law, the law speaks by the voice of conscience or is inscribed in the depths of the heart" (29).

The contempt towards laws of the South African racist state insistently practiced by Mandela and his friends is not in fact theirs; it is the reflection of the state's contempt and scorn of the law. Derrida calls this act of reflecting a "supplementary inversion" and for him it is the sign of true respect for the law. Outlaws like Mandela have placed themselves outside the law of the state and now they reflect the contempt and violence of that law and make it visible. Why does Mandela oppose the codes of his profession in his country and incite others to do the same? "It takes," Derrida says, "a decision that engages one's whole existence in its moral, political, historical dimensions" (33). In order to justify the transgression of the codes of a profession we need to understand the specific circumstances and contexts of an individual's life. Has Mandela treated “professional obligations lightly,” Derrida argues?

No, he is trying to think through his profession, which is not just an ordinary profession. [...] Mandela decides, to all appearances against the legal code, to exercise his profession just where they wanted to keep him from doing so. As a "lawyer worthy of that name," he sets himself against the code in the code, reflects the code, but making visible thereby just what the code in action rendered unreadable. (34, his emphasis) 
The unreadable is Mandela's target; the unreadability that the established law is ceaselessly struggling to preserve. The clandestine practice of the legal system is hiding something in the law and this is exactly what Mandela reflects in his reflection of the law. What he does is to bring to light something in the system that must remain invisible to the public; it is something that the system has made unreadable because of its practice, not because of the law as such. Mandela makes this unreadability readable by remaining in the profession and radically interpreting and reflecting the law. $\mathrm{He}$ remains unbendable and inflexible in his profession, not in the sense and interest of the state practitioners, but in the sense of a "law beyond the legality," and this "production of light is justice - moral and political" (34). Mandela highlights the unreadable, he casts light on the political violence of the whites, his challenge "holds to their interpretation of the law," making visible what is against "the spirit of the law" (34).

Although Mandela confesses his act of defiance of the laws of the state, he insists that he is pursuing his duty and is loyal to a superior law and responsibility: "that act has been forced upon us against our wishes, and we could do no other than to choose between compliance with the law and compliance with our conscience [...] I regarded it as a duty which I owed, not just to my people, but also to my profession, to the practice of law, and to justice for all mankind" (35). By reflection, Mandela can "repair, supplement, reconstruct, and add on a deontology where the whites were finally showing themselves deficient" (35). 
Derrida states that Mandela's pleading is "also an indictment" which is singular example for all humankind. Although Mandela's testament or plea is unique, it can be read in two ways, oriented either towards a vanishing ideal or to a possible future.

One can inflect it toward what bears witness only to a past and knows itself condemned to reflecting on what will not return: a sort of West in general, the end of a trip which is also the trajectory from a luminous source, the end of an epoch, for example that of the Christian West [...] But another inflection, if the testament is always made in front of witnesses, a witness in front of witnesses, it is also to open and enjoin, it is to confide in others the responsibility of a future. To bear witness, to test, to attest, to contest, to present oneself before witnesses. (37, his emphasis)

Mandela presents his testament to challenge the law and the state but at the same time tries "to reinstitute the law for the future" (37). Derrida argues that these two inflections are not only not opposed but they meet one another in "the exemplarity of the example when it concerns respect for the law" (37). Derrida mentioning Kant contends that we respect such persons because they give us the law; while the law is the source of this respect, "we must respect the other for himself, in his irreplaceable singularity" (37). Derrida argues that the answer to those who "see in Mandela the witness or the martyr of the past" is that "he has not only interiorized the law, we were saying, he has interiorized the principle of interiority in its testamentary tradition, Christian, that he 
does not merely repeat the lessons or the approaches of the past. In fact, he will illuminate a law that has not been seen completely even in the West:

[...] his [Mandela] reflection lets us see, in the most singular geopolitical conjunction, in this extreme concentration of all human history that are the places or the stakes today called, for example, "South Africa," or "Israel," the promise of what has not yet ever been seen or heard, in a law that has not yet presented itself in the West, at the Western border, except briefly, before immediately disappearing. (38)

What Mandela presents in his confrontation with the law is the promise of a law that has not yet been presented in Western democratic systems; it is a promise yet to be fulfilled but, with his singular example, this as yet-to-be-achieved future can be partially perceived. Derrida describes his conception of exemplary witnesses, "So the exemplary witnesses are often those who distinguish between the law and laws, between respect for the law which speaks immediately to the conscience and submission to positive law (historical, national, institutional). Conscience is not only memory but promise" (38). Singular examples are always required to decide between their conscience and the law. Derrida states that exemplary witnesses exist in many countries, like Bertrand Russell who put "conscience," "duty," "faith in the justice of the cause" "before the respect for the law" (39). Derrida continues that "it is out of respect that he [Mandela] did not show respect: no more respect. Respect for the sake of respect" (39). 
We will never cease to admire him, himself and his admiration. But we don't yet know whom to admire in him, the one who, in the past, will have been the captive of his admiration or the one who, in a future anterior, will always have been free (the freest man in the world, let us not say that lightly) for having had the patience of his admiration and having known, passionately, what he had to admire. The one refusing as early as yesterday a conditioned freedom. (41)

We admire Mandela because of his unique presentation of admiration through the inflexible logic of reflection. In his radically critical and free reflection, he highlights the deconstructability of different social-political-juridical systems and thinks of them as singular examples rather than exemplary. In his analysis of the question of singularity, Derrida defines Mandela's individual approach to the law and the state as singular and not exemplary. Derrida's emphasis is on the radically critical and free process of reflection of and response to the question of law and its ability to make visible in the law what the state suppresses so making possible in the future a better society and system for humanity. The notions of the law above laws and the voice of conscience are important aspects of becoming singular. Admirable decisions and actions in the world, like Mandela's, are only singular examples and not exemplary. Derrida indicates that we "are in a realm where, in the end, there are only singular examples. Nothing is absolutely exemplary" (263). 


\section{"who him received / With joy and acclamations loud"}

The Abdiel episode in Paradise Lost is part of Raphael's narrative to Adam about the events in Heaven before Adam and Eve's creation. Raphael is sent to Adam by God with the purpose of warning him and reminding him of his abilities and his granted free will so that he is able to stand fast against possible temptations. The story of Abdiel provides a unique example for Adam of a person who stands firm in an extremely difficult and challenging situation, so that he can learn from observing how Abdiel uses knowledge, reason and conscience to make a decision and act accordingly. Few individuals in Paradise Lost invoke God's admiration, and Abdiel is one of the few like the Son of God when he delivers himself as the atonement for man's original sin that is honoured by God because of his highly admirable actions. What is the reason for Abdiel's admiration?

Abdiel's first confrontation with Satan is in Book 5 (803-907), and the scene in which he is respected and admired by God and the angels in heaven for his remarkable resistance against the rebellious angels comes at the beginning of Book 6. After Abdiel abandons the fallen angels, he is "received / With joy and acclamations loud" (6.22-3) by God's faithful angels, and he is referred to by the epic narrator as unique: "That of so many myriads fall'n, yet one / Returned not lost" (6.24-5). Applauding him, they all appear before God who indicates that Abdiel's revolt against the multitudes of rebellious 
angels is admirable because his attempt was to maintain "the cause/ Of truth" (6.31-2). ${ }^{15}$ God stresses that Abdiel's defence of the Truth is not "in arms" but "in word mightier" (6.32). His first confrontation with Satan is meritorious enough for him to become the object of God's and other angels' admiration, but this is particularly notable because his challenge to Satan's new system of government is made in symbolic, not physical terms. His participation in the war against Satan and his followers is also precious but not so much to be praised and admired as a unique performance (there are numerous angels who fight against Satan). Abdiel's first confrontation with Satan is referred to as "the first assay" (153). The difference between his first and second confrontation is that in the battlefield one clearly knows his place and side and there is very little chance of being tempted and mentally challenged and deceived. However, to be among so-called friends and critiquing and challenging their beliefs and laws is in fact exceptionally difficult. This would culminate in contempt and serious sufferings "far worse to bear / Then violence" (6.34-5). One is strictly tempted to rethink and reconsider their thoughts and understanding when under the pressure of the crowd. When Abdiel beholds Satan who is rushing towards the war, he repeats God's statement that their first symbolic battle was more fundamental than the upcoming war. He was all alone at that time. ${ }^{16} \mathrm{He}$ states:

\footnotetext{
${ }^{15}$ See Margaret Justice Dean's essay "Martyrdom reconsidered: Adam's profit from Abdiel's example," in Milton in France, in which she argues that "most notably, Abdiel's commendation by God the Father is the highest praise afforded any created being in the epic, specifically situating it within Milton's definition of martyrdom" (230).

${ }^{16}$ For a discussion on Abdiel's "noble isolation" see Tung Mason's "The Abdiel Episode: A Contextual Reading," especially pages 601 and 606.
} 
His [Satan's] puissance, trusting in th' Almighty's aid,

I mean to try, whose reason I have tried

Unsound and false; nor is it aught but just,

That he who in debate of truth hath won,

Should win in arms, in both disputes alike

Victor $[\ldots](6.119-24)$

The reason that Satan is weak or helpless in front of his inferior angel Abdiel is not due to physical features or abilities. If someone like Abdiel is admired, it is due to their admiration of right reason and contemplation. Like Mandela, Abdiel is admired because he demonstrates himself as the true admirer of right reason and his conscience above all other principles. He challenges Satan's laws, defies him as his superior, and redefines his obligations. Instead, he obeys the superior law of right reason and conscience coming to his heart as God's absolute decree, law, or justice. Abdiel is the only one who remains faithful among the faithless, among "innumerable false"

$[\ldots]$ unmoved,

Unshaken, unseduced, unterrified,

His loyalty he kept, his love, his zeal;

Nor number, nor example with him wrought

To swerve from truth, or change his constant mind

Though single. (5.898-907) 
Abdiel demonstrates his steady reason and constant mind through a strictly challenging process of freely reflecting on his situation in order to choose a course of action. The situation opens up confusingly, when Abdiel steps outside its framework of law and power and creates the possibility of rethinking, to reveal conflicting imperatives and obligations. He is admired as a figure who demonstrates right reason, free will, and conscience in a radically confusing moment in which fundamental positions are suspended and re-examined, and because he chooses to return to the tents of truth.

Milton, like Derrida, exemplifies his notion of singularity through emphasizing the question of admiration and reflection. Abdiel is a singular example because of his radically free and critical act of contemplation and reflection on the questions of law, justice, and true decision. He both admires and is admired. Like Nelson Mandela, he demonstrates and asks for "admiration." Satan argues against God's decree and His Godhood in his confrontation with Abdiel. Abdiel refers to this theoretical and doctrinal argument with Satan as a trial, praised by God as a "better fight" because it is fought by right reason and conscience. In Book 5, addressing his legions, Satan says that God's decree has "eclipsed" them by putting them "under the name / Of King anointed" (5.776-77). They cannot endure a double servitude - to God and now to the Son. Satan calls God's decree a "yoke" on their necks and proclaims that they are natives and sons of Heaven and not sons of God, “possessed before / By none' (5.790-91). Although they are not equals, they are "yet free, / Equally free" (5.791-92). Because of this law, no angels can proclaim monarchy over their equals. Later, he claims that because they are good creatures and don't do anything wrong, there is no need for laws to be introduced. 
And last but not least, in the series of his justification, he refers to the titles God has given to the angels; "Thrones, Dominations, Princedoms, Virtues, Powers" (5.772), arguing that God's new decree has depreciated the meaning of these "imperial titles". Angels have been created to govern, Satan argues, but the new law leaves nothing of the meaning in the titles, making them mere servants now. Abdiel repels Satan's claims, calling his argument "blasphemous, false and proud" (5.809):

[...] Unjust thou say'st,

Flatly unjust, to bind with laws the free,

And equal over equals to let reign,

One over all with unsucceeded power.

Shalt thou give law to God, shalt thou dispute

With him the points of liberty, who made

Thee what thou art, and formed the pow'rs of Heav'n

Such as he pleased, and circumscribed their being? (5.818-25)

Abdiel's debate with Satan is a philosophical, theological, and metaphysical argument against the theoretical foundations of Satan's newly-established kingdom. His free rational contemplation of issues helps him to see through Satan's false logic. He submits freely and consciously to a superior law, God's Law that is now represented in his own 
reflection, right reason, and true conscience. ${ }^{17} \mathrm{He}$ is a figure of reflection and conscience, like Mandela. Not believing his ears, Satan counterattacks, questions God as the Creator, and proposes his theory of creation that angels are "self-begot, self-raised" (5.860); angels are the "ethereal sons / Our puissance is our own" (5.863-64). Abdiel denies this radical conception of individuality, while defining his singularity as the only one who dares to go against the newly established laws of his superior, Satan. His fearless conscience and right reason puts him in the dangerous situation of opposing Satan and against the laws of his newly founded state. He reflects the falsity and injustice of Satan's system to him and the other present angels like a mirror, making visible the pride, enviousness, unjustness, and irrationality of Satan's argument.

\section{Right Reason for Their Law}

In his argument in Book 5 of Paradise Lost, Satan focuses on the question of law as the main concern. The reason that angels follow him is his status: "for great indeed / His name, and high was his degree in Heav'n" (706-07). God discerns the revolt of the angels and knows that they "Were banded to oppose his high decree" (5.717) and that Satan intended "to erect his throne / Equal to ours" (5.725-26). In other words, Satan and other rebellious angels move to change their situation by reconceptualising their relationship to God and his state. After Satan with his legions reaches "The palace of

\footnotetext{
${ }^{17}$ Tung Mason in "The Abdiel Episode" asserts that the aim of his study is to argue that "freely Satan and his crew fell, freely Abdiel stood; freely Adam and Eve could have stood and remained happy in Paradise" (597).
} 
great Lucifer" (5.760), he demonstrates his own regal show in imitation of Heaven. Addressing the innumerable angels, he contends that by anointing a new king, the Messiah, God has impaired them. He questions God's decree and, pretending to practice his republicanism, he invites the crowd to debate the way to receive the new king. ${ }^{18}$ His claim to practice democratic consultation, voting, and deciding is not true. This is a good example of Derrida's idea that in the Apartheid regime the law is never properly established but is betrayed from the very outset. It also demonstrates that concepts like "democracy," "republican," "monarchy," "protestant," do not have a self-evident meaning for Milton. A republican polity like Satan's can be as undemocratic as a tyrannical kingdom. It is also possible that a monarchy could become the source of more justice and happiness for its people than a democratic state. Milton's critique of the perspectives that take such concepts and terms as self-evidently representing only positive or negative values is fundamental in all his works. Satan argues that they must cast off the Yoke of God:

But what if better counsels might erect

Our minds and teach us to cast off this yoke?

Will ye submit your necks, and choose to bend

The supple knee? Ye will not, if I trust

To know ye right, or if ye know yourselves

\footnotetext{
${ }^{18}$ In Paradise Regained, Satan tries to represent himself, the fallen angels, and his system as democratic. The narrator tells us that Satan "To Counsel summons all his mighty Peers" (1.40). He pretends to seek advice and conduct his new society as a democratic republic in opposition to the "Monarchy of Heaven," but the narrator tells us it is a "gloomy consistory" (1.43).
} 
Natives and sons of Heav'n possesed before

By none, and if not equal all, yet free,

Equally free; for orders and degrees

Jar not with liberty, but well consist. (5.785-93)

Satan's argument appears to leave them no choice and subsequently he questions God as the Creator by calling them "sons of Heaven" rather than sons of God. He indicates that all angels are free but not equal and they have different ranks. Satan claims that "reason" (5.794) does not allow monarchy and even though they are "in power and splendor less" (5.796) they are equals in freedom. He argues:

Who can in reason then or right assume

Monarchy over such as live by right

His equals, if in power and splendor less,

In freedom equal? or can introduce

Law and edict on us, who without law

Err not, much less for this to be our Lord,

And look for adoration to th' abuse

Of those imperial titles which assert

Our being ordained to govern, not to serve? (5.794-803)

Satan presents two more reasons here. He questions the imposition of laws by one over others when all have an equal right to freedom, and the requirement to serve when they 
had been ordained to govern. The word "ordain" asserts his claim to their original freedom and power that God as a tyrant has usurped. Abdiel calls Satan's argument "blasphemous, false, and proud" (5.809)! He contends that it is "by experience" that the angels know how good God and his Son are and instead of making the angels less, God's aim is to exalt "Our happy state under one head more near / United" (5.830-31), renouncing Satan's argument that the Son is like the other angels and that equals cannot govern each other. He argues that to be under the head of the Son is not to obscure the other angels' existence and importance: "But more illustrious made, since he the head / One of our number thus reduced becomes" (5.842-43). Accordingly, to serve in the Son's kingdom and to obey "His Laws our laws" (844) is just. If we honour him, in fact, it "[r]eturns our own" (845). By contrast, Satan presents his theory of "self-begot, self-raised" creation to establish his own republican system. His own kingdom is founded on new rules and laws, demonstrating that laws and structures are indispensible though always incomplete.

Abdiel who is alone in the legions of evil replies fearlessly that they are empty and "forsaken of all good" (5.878). He declares that from now on God's "indulgent laws / Will not be vouchsafed" (5.883-84) and other decrees against Satan have "gone forth without recall" (5.885). Abdiel announces his decision to fly away from Satan's "wicked tents." Like Mandela, Abdiel bears the "universal reproach" - among the people of the white state and others - for the sake of "the testimony of truth" (6.33), but what is important for Abdiel is to be approved by God and to remain "in sight of God" 
even if the world "[j]udged thee perverse" (6.37). He believes in the superiority of true reason and conscience and fights for the true law, the law as such.

Abdiel's ultimate decision is to reject Satan's newly proclaimed laws and system. Satan's interpretation of the laws of Heaven corrupts their meaning in the same way that the white government of South Africa represented western democratic laws in their own way and corrupted them. Abdiel radically questions Satan's reasons and develops his response through an intense process of thinking and reasoning. He radically reviews the fundamental questions of the law, God's Law, conscience, self, and justice. In Abdiel's case, like that of Mandela, the law - equals cannot govern equals - is used by Satan against itself. Satan claims that their nature and existence clearly articulated in God-given titles - Thrones, Dominations, Princedoms, Virtues, Powers - have been devalued by God's new law that places an "equal" head over them in the person of the Son of God.

The question of responding to right reason and conscience is contrasted with the question of obedience to the self. Self-obedience is self -slavery. Arguing the meaning of the terms "servitude" and "freedom," Abdiel distinguishes obedience to conscience and right reason from obedience to one's self. Satan derides the divine angels as "[m]inist'ring spirits" (6.167) and questions their freedom, calling it nothing more than mere "[s]ervility" (6.169). Abdiel repels his argument claiming of their serving in Heaven that "Unjustly thou deprav'st it with the name / Of servitude" (6.174-75) because to serve God is the same as attending to nature and both "bid the same" 
(6.176). They serve God who is the "worthiest" and "excels / Them whom he governs" (6.177-78). To serve God or the Son is what nature dictates and if true reason or conscience is a natural inner power then what they persuade us to obey is the "worthiest" (6.185). Abdiel argues that servitude is when you "serve th' unwise" (6.179), as Satan's legions do. In other words, the element of right reason is always determining and decisive. This emphasis on reason and wisdom highlights the significance of the individual's free will and his responsibility. Abdiel states:

\section{[...] This is servitude,}

To serve th' unwise, or him who hath rebelled

Against his worthier, as thine now serve thee,

Thyself not free, but to thyself enthralled;

Yet lewdly dar'st our minist'ring upbraid.

Reign thou in Hell thy kingdom, let me serve

In Heav'n God ever blest, and his divine

Behests obey, worthiest to be obeyed,

Yet chains in Hell, not realms expect: [...] (6.178-86)

Abdiel acknowledges that there can be different links of kingdom/state, but what they have in common is their foundation in law and the force to establish and maintain that law. He is not a slave to his self when his conscience affirms God's law and justice. He is free to question or accept Satan's arguments and show (dis)obedience to his superior. He moves in the direction of truth by freeing his reason from Satan's principles and 
laws. His free conscience follows the principle law of searching for truth and justice that are irreducible to any laws.

\section{"One just Man" and Singular Examples}

Mandela radically reviews the history of his land and that of Europe in terms of the relations between individuals and the laws. He admires both freedom and equality in his ancestors' societies in South Africa and the tradition of freedom and democracy in the West. Mandela's memory and conscience recalls and promises a better law and state system for South Africa in the future. He does not claim to have complete access to that law or form of democracy. Demonstrating himself progressively as becoming a democratic intellect, he is hoping that they become possible due to his radical critique of the established laws. Abdiel's right reason and conscience are both memory and promise as well: memory because, after hearing Satan's critique of God's decree, he remembers all his knowledge in that relation and radically reviews it; and promise because he is not sure about the implications and future effects of his decision. His mind becomes clear that he must choose the voice of his conscience over Satan's claims for the future. In Milton's argument, God's law speaks directly to the heart of the individual, which demonstrates similar characteristics to Derrida's "law of laws" or "sentiment of justice." Both Mandela and Abdiel respond to a superior and irreducible law that becomes a source of righteousness and true energy to empower the individual to make a free and just decision. 
The examples in Milton's works that can be examined as singular examples of his fit reader or "just man" are many, including the Son of God in Paradise Lost or in Paradise Regained, Samson in Samson Agonistes, Abraham, Job, and Noah in Paradise Lost. Milton's fit reader demonstrates similar qualities to Derrida's singular examples like Mandela and his notion of democratic intellect. Milton's own life-long critical approach to institutions and systems of his time proves him to be a singular example as well. His The Tenure of King and Magistrates or Areopagitica provide clear evidence. To Milton, all singular examples are admirable; however, he fundamentally emphasises the importance of contextual factors in considering them. Specific contexts introduce elements of indeterminacy and undecidability into the process of decision-making. These admirable figures (fit readers) demonstrate their singularity in moments/spaces of undecidability by making radical decisions which challenge customs, conventional knowledge, and established rules and laws and then by enacting those decisions due to which possibilities of social change and development might be realised. The following paragraph by Derrida written about Mandela is true also of all Milton's singular examples of fit readers developed in his works, himself included:

He presents himself in his people, before the law. Before a law he rejects, beyond any doubt, but which he rejects in the name of a superior law, the very one he declares to admire and before which he agrees to appear. In such a presentation of the self, he justifies himself in resuming his history, which he reflects in a single centre, a single and double centre, his history and that of his people. [...] The presentation of the self is not in the service 
of the law, it is not a means. The unfolding of this history is a justification, it is possible and has meaning only before the law. He is only what he is, he, Nelson Mandela, he and his people, he has presence only in this movement of justice. (5, his emphasis)

Milton and Derrida demonstrate the admirable singularity of singular figures to prevent them being adopted as absolute models of decision-makings and actions for all times and places. Both writers consistently and emphatically highlight the necessity of the radically critical and free approach one must take in order to act truly and justly in different situations, cases, and contexts. Abdiel, like the Son of God in Paradise Regained and Samson in Samson Agonistes, is a fit reader alone among those who decide and act differently from him. He is in a different situation because his decision and act are confirmed and commended by the ultimate authority of God. These absolute confirmation and commendation do not exist in history after the Fall. Paradise Lost places its characters and their actions in an environment where direct or mediated access to the truth is possible whereas, in the two late poems, this situation does not exist. 


\section{Chapter Two}

\section{Public Space without Conditions}

In this chapter, the focus of the argument is on the necessity of a public space in which the possibility of radical critique could exist. I will discuss Milton's Areopagitica and Derrida's essay, "The Future of the Profession," in Derrida Downunder to support Areopagitica's privileged position as the great treatise on freedom of the press. In Areopagitica, Milton focuses on the importance of public space and defends the free operation of intellectual work for the revelation of truth. A free public space needs an institutional guarantor which is "the Parliament" for Milton and "the university" for Derrida. This institution should exercise an unconditionality that goes beyond the known attributes, limitations, and characteristics of private/public space. Both authors argue for the indispensability of this public space in which everything can be radically suspended, questioned, re-examined, and critiqued; a space in which no system's laws are exempt from radical examination and deconstruction for the sake of truth and justice, democracy, and humanity to come.

In his essay in $1987,{ }^{19}$ Stanley Fish positions his argument against the previous body of Milton readings, which have almost always commented on Areopagitica as "a classical liberal plea for 'complete liberty"' (235). He claims that "Milton is finally, and in a profound way, not against licensing, and that he has almost no interest at all in the

\footnotetext{
${ }^{19}$ See Stanley Fish's "Truth and Indeterminacy" in Remembering Milton.
} 
'freedom of the press' as an abstract or absolute good" (235). He argues that Milton consciously recognized freedom of the press as conditional and given to some by authorities as a privilege. In 2005, James Rovira ${ }^{20}$ wrote that the modern scholarship on Milton's Areopagitica - referring to Stanley Fish and other critics in his camp ${ }^{21}$ - has been "understandably perplexed on some points" (87). He argues that Fish's interpretation of Areopagitica was "terribly wrong" and a "colossal misunderstanding" (87). In fact, he criticises the qualifications on freedom of speech attributed to Milton by "the modern Milton scholarship" as exaggerations. ${ }^{22}$ Rovira concludes his essay as follows:

It is too much to say Milton had little or no concern for the institution of a free press in England, just as it is too much to say that Milton conceived of freedom of the press in the way modem readers do. Both errors are the products of ignoring intellectual and historical referents $[\ldots]$ The Areopagitica should retain its privileged position as the great treatise on freedom of the press in western liberal democracies, its qualifications, contradictions, and shortcomings understood as an inherent part of an

\footnotetext{
${ }^{20}$ See James Rovira's "Gathering the Scattered Body of Milton's 'Areopagitica'" in Renascence-Essays on Values in Literature.

${ }^{21}$ See John Illo's essay, "The misreading of Milton," in Radical Perspective in the Arts and Willmore Kendall's "How to read Milton's Areopagitica." Furthermore, see Abbe Blum's "The Author's Authority" in Remembering Milton, published simultaneously with Fish's essay and asking "How are we to read a tract which encodes much greater freedom and recognition for an author (aside from a Catholic) and at the same time grants the state's right to exercise corporal punishment on the offending author's product?" (77); Ernest Sirluck's Complete Prose Works of John Milton; and Vincent Blase's "Milton's Areopagitica and the Modem First Amendment."

${ }^{22}$ See also James Rovira's essay, "Milton's Ontology of Books and Areopagitica," in Milton in France.
} 
ongoing dialogue on freedom of expression, a dialogue, which Stanley Fish reminds us "can never stop." (“Gathering” 101)

My argument in this chapter will support the Areopagitica's privileged position as the great treatise on freedom of the press through a different emphasis. I intend to argue that, in Areopagitica, John Milton addresses the question of public space without conditions, emphasizing its indispensability for society and individuals and for the free operation of critical intellectual work for the revelation of truth. Therefore, Milton's main concern in his treatise is to underline the necessity of the ongoing search for the revelation of truth by free radical reading and writing, and intellectual work guaranteed by an unconditional public space. This emphasis is a consequence of reading Derrida's thoughts on the same issues in his essay, "The Future of the Profession." Given the very different historical, cultural, and social locations of each writer, there are significant continuities and convergences in their thoughts on the question of public space, truth, independence, and the nature and responsibility of intellectual work. Milton and Derrida similarly account for the indispensible unconditionality of a public space. The ways in which public space is understood and exemplified in their works are strongly marked by different forms of dominant institutions, procedures, and contexts for the formation of new knowledge, and political and cultural conditions in relation to which each writer positions himself. I will represent my argument in a parallel structure in three sections on each author: the incompleteness of truth in the world and the necessity of ongoing search for truth; the absolute need for free intellectual work and radical critique; and the 
indispensability of unconditional public space provided by independent institutions to guarantee the principle of the right to say everything.

\section{Enigmatic Truth and its Indeterminable Horizon}

For Derrida, the representation of truth in this world will always remain partial, incomplete, and ongoing. There is neither a beginning nor an ending for the process of the revelation of truth in the world. He acknowledges the lack of the presence of an absolute truth in the world. In his article, "The Future of the Profession," Derrida argues that for "the university" to be a space within which the truth "finds its best access to a new public space transformed by new techniques of communication, information, archivisation, and knowledge production" (234), it must remain unconditional. For him, the university as an institution is responsible for guaranteeing a free and public space in the sense of an open space of enquiry without conditions that would limit its representation of and engagement with the possibilities of knowing. This independent, unconditional institution must be faithful to its professed responsibility, which is to declare and promise unlimited commitment to the revelation of truth. It must provide and defend unconditional access to a public space in which nothing is safe from questioning.

In his essay, "The Future of the Profession," Derrida argues that there is no doubt that "the status of changes to the value of truth can be discussed ad infinitum" and they are discussed "in the university and in departments that belong to the Humanities" (234, his 
emphasis). The question of truth for Derrida is an ongoing search which remains fundamentally incomplete and always to be pursued. In his thought, "the reference to truth remains fundamental enough to be found, along with light (lux), on the symbolic insignias of more than one university" (233). The incompleteness of truth is something that Derrida ascribes to the nature of language and the impossibility of presenting truth through language in this world. For him there is no access to an absolute, divine, and prehistoric form of truth in this world; there is only history and nothing but history. Derrida believes in the radically free play of language and context in which the fullest capabilities of language can find their expression.

No matter how enigmatic and inaccessible the truth might be in this world, the search for truth remains a fundamental aspect of Derrida's conception of deconstruction and thought. For him the institution of the university, but specifically the humanities to come, is the place and space in which the ongoing search for truth must be deconstructively pursued and find its own special place. In his discussion on the unconditionality of the university, he emphasizes the importance of research concerning truth:

This university claims and ought to be granted in principle, besides what is called academic freedom, an unconditional freedom to question and to assert, and even the right to say publicly all that is required by research, knowledge, and thought concerning the truth. (233, his emphasis) 
Throughout his essay, Derrida contends that the outcomes of such a process will remain imperfect, incomplete, and partial but undoubtedly indispensible to our understanding of what it means to be human. This everlasting process of activities of interpretation, critique, and questioning suggests the notion of the to-come. Truth, according to Derrida, remains to be found forever as the to-come. He asserts that the "horizon of truth or of what is proper to man is certainly not a very determinable limit" (235).

\section{Singular Oeuvres and Unconditional Resistance of Deconstruction}

The question of research, knowledge, and thought concerning the truth is an indispensible requirement of Derrida's thought. Intellectual work, although discussed in relation to the modern institution of the university, the Humanities, and academic freedom, is demonstrated by Derrida to be an act that can only result in a partial revelation of truth relevant to understanding humanity. However, intellectual work must be given an unconditional freedom to engage in unrestricted research and questioning for the sake of truth. Derrida argues:

But whether these discussions are critical or deconstructive, everything that concerns the question and the history of truth, in its relation to the question of man, of what is proper to man, of human rights, of crimes against humanity and so forth, all of this must in principle find its space of discussion without condition and without presupposition, its legitimate space 
of research and re-elaboration, in the university and within the university, above all in the Humanities. (234, his emphasis)

For Derrida, the intellectual work must be carried out so fundamentally and radically that it would turn it into "an ultimate place of critical resistance" (235). Moreover, the critical resistance must be "more than critical - to all the powers of dogmatic and unjust appropriation" (235). This radically critical resistance is what Derrida calls deconstructive critique. There is a fundamental difference between the intellectual work Derrida is elaborating and the critical researches and studies already pursued in universities and research institutions. Derrida calls for a radical and unconditional critique or questioning in the university:

I am referring to the right to deconstruction as an unconditional right to ask critical questions not only to the history of the concept of man, but to the history even of the notion of critique, to the form of thought. For this implies the right to do it performatively, that is by producing events, for example by writing, and by giving rise to singular oeuvres (which up until to now has not been the purview of either the classical or the modern Humanities). (235, his emphasis)

Derrida's radical critique or deconstruction is a right for the university and the new Humanities that must even begin "with the deconstruction of their own history and their own axioms" (235). Writing, as Derrida argues here, can be the 
product of the practice of unconditional resistance, in the form of "singular Oeuvres." Texts or writings can become an unconditional resistance against established powers of the state, economy, media, ideologies, religions, and cultures that would delimit the possibilities of the revelation of truth and justice in societies. For Derrida, the work of writing and other forms of texts, if produced through an unconditional, radical critique, is capable of becoming an event or a performative act:

[...] with the event of thought constituted by such oeuvres, it would be a matter of causing something to happen, without necessarily betraying it, to this concept of truth or of humanity that forms the charter and the profession of faith of all universities. This principle of unconditional resistance is a right that the university itself should at the same time reflect, invent and pose, whether it does so through its law faculties or in the new Humanities capable of working on these questions of right and of law - in other words, and again why not say it without detour - the Humanities capable of taking on the tasks of deconstruction, beginning with the deconstruction of their own history and their own axioms. (235)

\section{The University without Conditions and the Humanities To-come}

Derrida argues for the necessity of an academic or intellectual place in society within which unbounded critique can take place. For him, the new Humanities, that is still not 
present, is the place of such a deconstructive approach. Unbounded critique and interpretation is the way through which the emergence of some new truth might become possible. An unconditional public place must make possible the revelation of new truth through the release of the possibilities of language by following an unbounded critical approach. Given the importance of critique, Derrida delineates a specific social-political place/space for it and its practitioners.

In his essay, "The Future of the Profession," Derrida argues that the "modern university should be without condition" (233, his emphasis). He defines modern university as the European model with "a rich and complex medieval history" (233) prevalent in democratic states. This university claims to enjoy in principle not only academic freedom but also an unconditional freedom to question everything concerning the truth. No doubt, this is a claim and something granted only in principle; this unconditional public place remains to come: "The university without condition does not, in fact, exist, as we know only too well" ("The Future" 235).

The crucial elements in Derrida's definition of the university without condition are the right to say everything in addition to dedicated public space. He emphasizes that the right to say everything and the right to publish everything must have their special place in the public realm. Derrida argues that the public space fundamentally links the 
university and above all the Humanities to fiction ${ }^{23}$ or experimentation of knowledge. The public element also distinguishes the university from other institutions in which the right to say everything may be granted with no public dimension, and is restricted to members of such institutions, for instance, religious or psychoanalytic confessions. The freedom practiced in these institutions lacks the significant requirement of public utterance. For unbounded, public critique to be possible, the public space in which it occurs must be able to guarantee the right to say everything. Therefore, no power, institution, or systems of thought should feel safe and secure from the fundamental critique of such a public space.

Derrida argues that, for the university to be a space within which the truth "finds its best access to a new public space transformed by new techniques of communication, information, archivisation, and knowledge production" ("The Future" 234), it must claim to be unconditional and independent with no presuppositions and curbs of "the marketplace in publishing and the role it plays in archivisation, evaluation, and legitimation of academic research" ("The Future" 234-35). In his thought, without the existence and support of such a space there is no hope of radical critique of socialpolitical systems and structures. For him, the existence of this space and access to it means access to the possibility of unbounded critique.

\footnotetext{
${ }^{23}$ Derrida asserts that by fiction he means "literature" in the "European and modern sense of the term, as the right to say everything publicly, or keep it secret, if only in form of fiction" (236). See my discussion in Chapter Five.
} 
One of the concepts that Derrida thinks must be questioned within this unconditional public space is the concept of man. He argues that the concept of man is "both indispensible and always problematic," and must be re-elaborated "as such and without conditions, without presumptions, only within the space of the new Humanities" (934). The revaluation of such problematic questions and concepts has happened, is happening, and will happen forever through the new Humanities. The university and the new Humanities must be a public place for the radical questioning of everything related to the history of truth, the question of man, human rights, crimes against humanity and so forth. To Derrida, the university is an institution that must act as the defender of truth, not truth that has a pre-existence and prefigured form, but the truth which will show itself in the form of impossibility and through unbounded critique. It is a democratic space/place, which must critique even the concept of critique itself. It is independent from all powers, the characteristic that speaks of both authority and vulnerability. It has authority due to its extreme power of critique and its access to the public space. It is vulnerable because it is not dependent on (therefore not supported by) any institutional power to control it. Therefore, there is always the risk of capitulating to a power because it is "without power" and without condition. The university is always exposed and destined "to capitulate without condition, to surrender unconditionally" (237). Because of its unconditionality, there is always the risk that university gives itself up, "it sometimes puts itself up for sale, it risks being simply something to occupy, take over, even buy; it risks becoming a branch office of conglomerates and corporations" (237). Derrida argues that the unconditionality of the university 
[...] exhibits the fragility of its defenses against all the powers that besiege

it, and attempt to appropriate it. Because it is a stranger to power, because it is heterogeneous to the principle of power, the university is also without any power of its own. That is why I speak of the university without condition. (236, his emphasis)

Universities and research institutions often allow themselves to be sponsored or more correctly controlled "by commercial and industrial interests" (237). The problem is that the Humanities "are often held hostage" to the science departments because they are industrially and economically more profitable and influential. However, Derrida speaks of a "privileged place of presentation, of manifestation, of safekeeping" of the principle of unconditionality or the right to say everything in the Humanities or the university. In other words, the principle of freedom, autonomy, resistance, disobedience, or dissidence finds a privileged place in the university or the new Humanities. The university can be "the place of irredentist resistance" or "a sort of principle of civil disobedience, even of dissidence in the name of a superior law and a justice of thought" (238).

As demonstrated in his works, Derrida is interested in a lawless energy or desire, which must be liberated in the public places/institutions, most significantly in the university, the new Humanities, literature, ${ }^{24}$ law schools, and so forth. He insists that by the term "thought" in "the justice of thought" he means "that which at times commands,

\footnotetext{
${ }^{24}$ Literature, for Derrida, is the modern democratic institution that claims to have in principle the right to say everything. See my discussion in Chapter Five.
} 
according to all laws, the justice of this resistance or this dissidence" (238). This call, desire, or energy is "what puts deconstruction to work or inspires it as justice" (238). It is the call of deconstruction or "the faith of deconstruction." ${ }^{25}$ This energy or desire is deconstruction itself, is justice itself, it is deconstruction as justice. Derrida argues:

This right must be without limit, if I may say so, to authorize the deconstruction of all the determined figures that this sovereign unconditionality may have assumed through history. For this, we have to enlarge and re-elaborate the concept of the Humanities [...] This new concept of the Humanities, even as it remains faithful to its tradition, should include law, 'legal studies' as well as what is called in the United States, where this formation originated, 'theory' (an original articulation of literary theory, philosophy, linguistics, psychoanalysis, and so forth), but also, of course, in all these places, deconstructive practices. (238)

Both theory and practice are crucial in the new Humanities because deconstruction happens in both realms. Derrida asserts that he would like to connect the problematic of the university without condition to "a pledge, a commitment, a promise, an act of faith, a declaration of faith, a profession of faith that in an original way ties faith to knowledge in the university and above all in that place of self-presentation of unconditionality that will go by the name Humanities" (239). He links faith to knowledge because, as I discussed in the case of Mandela and Abdiel in Chapter One,

\footnotetext{
${ }^{25}$ See Theodore W. Jennings's Reading Derrida/Thinking Paul: On Justice, especially the conclusion.
} 
to critique the law or truth from within is a singular act requiring faith in the existence of a law above the laws and belief in the role of conscience.

\section{Milton on Public Space without Conditions}

The exploration of Milton's position on public space without conditions in Areopagitica shows that for him the representation of truth in the world always remains a partial, incomplete, and continuous process. However, unlike Derrida, he believes that one day this ongoing process will come to its end via divine assistance; that is, Christ's Second Coming as the time of recompletion of the shape of truth and the end of all ambiguities and problematics of the world; the time unmediated truth and justice appear in the world. Like Derrida, he acknowledges the lack of the presence of an absolute truth in the world. In Areopagitica, Milton's critical argument highlights the necessity of a publicly maintained space for critique when discussing the question of "liberty of unlicensed printing." Milton argues that the licensing order of the Parliament is against the desire of "the sad friends of truth" who attempt to recover its pieces together in this world; and it is against the professed responsibility of the Parliament to defend the truth.

The main themes of Milton's discussion in Areopagitica include the question of law and right, the concept of man as a free creature, the necessity of the knowledge of good and evil for man. In addition, he accounts for the concept of the public space in connection to writing and the publishing industry, intellectual work, and the importance of the Parliament as the guarantor of this space. For Milton, the public space is generated by 
democratic conceptions of society guaranteed by the institution of the Parliament as the State. Addressing the Parliament, Milton reminds them of their acknowledged duty and responsibility to defend the truth, the good of the public, and the support of a public space within which the truth finds opportunities and possibilities to be revealed and defragmented. It must provide and support the conditions necessary for the radical critique of systems and institutions of society.

\section{Streaming Fountain of Fragmented Truth}

For Milton, truth has a prehistoric form, but in history its condition is attributed to "a wicked race of deceivers" who "took the virgin Truth, hewed her lively form into a thousand pieces, and scattered them to the four winds" (955). After the disintegration of truth, history is understood as the continuous quest for truth by true people seeking to bring its fragments together. In Areopagitica, Milton argues that the process of bringing more of the truth to the world and restoring its perfect original form is a continuous task and commitment. ${ }^{26}$ This process has been contributed to throughout history by different peoples in various situations and it is slowed down if not stopped by the licensing order passed by the Parliament. Accordingly, Milton calls for the abolition of the licensing order in the name of truth. Even though Milton believes in an absolute truth, he argues that, after the fall of Adam and Eve, the representation of this absolute truth in the world remains incomplete and uncertain. David Ainsworth, in his book Milton and the

\footnotetext{
${ }^{26}$ For more on Milton's focus on a never-ending search for truth, see John R. Knott's Discourses of Martyrdom.
} 
Spiritual Reader, argues that for Milton "believers recover truth through process; they don't create it" (190). Defragmentation of the truth is conditional on what human beings do and the society and context in which they live and think. The ongoing process of discovering truth is the endless task of man's intellectual work (thinking, reading, writing, etc) within human social-political structures.

After the Fall and the expulsion of Adam and Eve from Paradise, the recovery of truth becomes possible in history although as an ongoing process. For Milton, truth is like a "streaming fountain $[\ldots]$ in a perpetual progression" (952). Like the experience of faith and knowledge, the experience of truth is individual and singular, and everyone must go through it personally and individually. To Milton the representation and understanding of truth is a singular and personal commitment that is impossible to be replaced by the mere acceptance of what others think or what institutions define as the truth. The process of acquiring knowledge, faith, or truth depends upon individual application and decision. Milton asserts:

Well knows he who uses to consider, that our faith and knowledge thrives by exercise, as well as our limbs and complexion. Truth is compared in scripture to a streaming fountain; if her waters flow not in a perpetual progression they sicken into a muddy pool of conformity and tradition. (952)

Milton argues that Plato's laws in "his fancied Republic" are useless and vain because of the complex nature of the forces involved in the process of learning how to live in 
society. This individual experience cannot and should not be restricted through laws and regulations with the purpose of shutting doors to corruption. To Milton, such a task is fundamentally complex and problematic. He indicates:

For if they [Plato and any magistrates] fell upon one kind of strictness, unless their care were equal to regulate all other things of like aptness to corrupt the mind, that single endeavor they knew would be but a fond labour; to shut and fortify one gate against corruption, and be necessitated to leave others round about wide open. If we think to regulate printing, thereby to rectify manners, we must regulate all recreations and pastimes, all that is delightful to man. No music must be heard, no song be set or sung, but what is grave and Doric. (942-43)

Milton argues that "to sequester out of the world into Atlantic and Utopian polities" will not resolve our problem in the world and will not "mend our condition" (943). God has "placed us unavoidably" in "this world of evil" (943). We must "ordain wisely" rather than escape to the world of nowhere (utopia) which ultimately cannot help us in our evil condition. Milton rejects Plato's licensing of books because he believes it "will make us all both ridiculous and weary, and yet frustrate" and instead declares that we must follow "those unwritten, or at least unconstraining laws of virtuous education, religious and civil nurture, which Plato there mentions, as the bonds and ligaments of the commonwealth, the pillars and the sustainers of every written statute" (943-44). 
To Milton, the licensing order will be more for the benefit of evil and tyranny than protecting man from evil. The practice of such a law would obstruct the revelation of truth in the world. Milton writes in favour of the liberty of unlicensed printing because he believes the public space created by such a freedom leads to more understanding, clarity, truth, and knowledge of good. For him, a free public space resists evil and tyrannical powers in all their social and political forms through the work of free writing, reading, and publishing. The space of publishing must be a public space within which everyone, if capable, must have the right and opportunity to deliver his argument and contention, free from the authorities and controlling powers. Areopagitica is concerned very much with the question and the history of truth, the story of truth coming to the world, its fragmentation and then the process of its defragmentation, and its relation to the question of man.

\section{Fabulous Dragon's Teeth and Public Advice for Truth}

The licensing order of the Parliament is what Milton writes against because it delimits the practice of interpretation, writing, and reading and leads to the restraint of the public space and free intellectual work. Milton indicates that all books, good or bad, must be published and each writer must enjoy the right to express their opinions to the public. The public space in which the intellectual work takes place must be supported by the Parliament in order to bring more of the truth into the world. Each published work has its own contribution to the ongoing process of the representation of truth. In Areopagitica, Milton defends even the necessity of bad books, their possible 
contribution to the knowledge of good, and the revelation of truth. The representation of truth from Milton's perspective would be more possible (never complete) only if there is freedom of intellectual work and critique. For him, the practice of free writing, interpretation, and intellectual work is equal to providing more opportunities for the recovery of truth. Hence, the licensing order of the Parliament "will be primely to the discouragement of all learning, and the stop of truth, not only by disexercising and blunting our abilities in what we know already, but by hindering and cropping the discovery that might be yet further made both in religious and civil wisdom" (930). ${ }^{27}$

In Areopagitica, Milton argues that gaining the knowledge of good is inseparable from the knowledge of evil. He argues that the two kinds of knowledge are totally connected, dependent, blended, "intermixed," and "interwoven." Milton states:

Good and evil we know in the field of this world grow up together almost inseparably; and the knowledge of good is so involved and interwoven with the knowledge of evil, and in so many cunning resemblances hardly to be discerned, that those confused seeds which were imposed on Psyche as an incessant labour to cull out, and sort asunder, were not more intermixed. It was from out the rind of one apple tasted, that the knowledge of good and evil as two twins cleaving together leapt forth into the world. And perhaps

\footnotetext{
${ }^{27}$ For further discussion on the indispensability of free intellectual work even in our time, see Barbara Lewalski's "Barbara K. Lewalski on Why Milton Matters."
} 
this is that doom which Adam fell into of knowing good and evil, that is to say of knowing good by evil. (938-39)

Books for Milton are alive and generative. They contain "a potency of life in them" and are "as active as" the soul that creates them. In other words, books preserve "the purest efficacy and extraction of that living intellect that bred them" (930). Milton uses the allusive metaphor, "the fabulous dragon's teeth," for the liveliness and productivity of books. They can spring up armed men; that is, they can have real effects, but not necessarily either predictable or peaceful. This metaphor indirectly associates limitlessness, mysticalness, and uncontrollability with books. Books generate conceptions, ideas, and the possibility of understanding. In Milton's framework of thought, books are vigorously productive and lively to the extent that they are the communicator of their creators' soul. More than that, they contain the soul - a reference that makes language the vehicle, not the source. A book or an intellectual work has life after it is produced. Milton's emphatic discussion here demonstrates that for him the question of singularity plays the most significant role in understanding different works of writing, reading, interpretation, meaning-making, and so forth. ${ }^{28}$ The element of singularity has to be considered in regard to the question of man as the writer, on the one hand, and reader on the other hand. It is also considered in terms of the work itself. Milton argues:

\footnotetext{
${ }^{28}$ See my discussion of the question of singularity and exemplarity in Chapter One.
} 
[...] who kills a Man kills a reasonable creature, Gods Image; but he who destroys a good Book, kills reason itself, kills the Image of God, as it were in the eye. Many a man lives a burden to the Earth; but a good Book is the precious life-blood of a master spirit, embalmed and treasured up on purpose to a life beyond life. 'Tis true, no age can restore a life, whereof perhaps there is no great loss; and revolutions of ages do not oft recover the loss of a rejected truth, for the want of which whole Nations fare the worse. We should be wary therefore what persecution we raise against the living labors of public men, how we spill that seasoned life of man preserved and stored up in Books; since we see a kind of homicide may be thus committed, sometimes a martyrdom, and if it extend to the whole impression, a kind of massacre, whereof the execution ends not in the slaying of an elemental life, but strikes at that ethereal and fifth essence, the breath of reason itself, slays an immortality rather than a life. (931)

As discussed above, Milton ascribes treasures, precious life-blood, the breath of reason, and immortality to books. Books are more vital and imperative than even the author; they are immortal in comparison to the mortal life of the author. Milton warns that not only do the licensing order and similar laws fail to prevent evil and the knowledge of evil in human life, but also they block and destroy the flow of the representation of truth and knowledge of good. Milton reasons that to ban books in order to protect humans from evil is vain and fruitless because evil has other means to represent itself to the world and society: 
$[\ldots]$ and that evil manners are as perfectly learnt without books a thousand other ways which cannot be stopped; and evil doctrine not with books can propagate, except a teacher guide, which he might also doe without writing, and so beyond prohibiting, I am not able to unfold, how this cautelous enterprise of licensing can be exempted from the number of vain and impossible attempts. (941)

There is a sense of uncontrollability and extreme complexity in the life and the world of learning and disputation in Milton's thought. It is not that simple to ban evil ideas or doctrines just by licensing books. There are "a thousand other ways" through which evil/good can be represented in the world. Milton does argue that there is an extremely complex and uncontrollable network of signs that work to transmit the knowledge of good/evil or the truth. This network is not just the work of language and writing (linguistic) in the narrow sense of the terms. There are other means through which the representation of truth and the knowledge of good can be provided and mediated. This is more the emphasis on a force operating at the symbolic level of the society, in the doctrines, disputations, and interpretations of the world of learning and teaching. Milton's idea converges with and resembles Derrida's argument on the interpretive and performative forces active in society and the possibilities and potentialities within the systems of signs. Different sign systems for Milton cannot be controlled simply by a licensing law or order, although such a law would have serious limiting effects. 
The complexity and uncontrollability of these interpretive, performative forces are replete with a confusing mixture of evil/good. Metaphorically speaking, the systems of signs are like an ocean out of which the knowledge of good and truth is expected to be taken. For Milton, these complex systems and forces ultimately work their way through to evade confining laws like the parliamentary law of printing. It is more logical, fruitful, democratic, humane, and divine to let these forces play out their moves and strength through which more of the truth and knowledge of good will be delivered. The truth is an infinite force or strength which will always make its presence known but more fully in the knowledge system of a free society: "[s]ee the ingenuity of Truth, who when she gets a free and willing hand, opens herself faster than the pace of method and discourse can overtake her" (942).

As therefore the state of man now is, what wisdom can there be to choose, what continence to forbear without the knowledge of evil? He that can apprehend and consider vice with all her baits and seeming pleasures, and yet abstain, and yet distinguish, and yet prefer that which is truly better, he is the true warfaring Christian. I cannot praise a fugitive and cloistered virtue, unexercised \& unbreathed, that never sallies out and sees her adversary, but slinks out of the race, where that immortal garland is to be run for, not without dust and heat. Assuredly we bring not innocence into the world, we bring impurity much rather: that which purifies us is trial, and trial is by what is contrary. (939) 
In his essay, "The Abdiel Episode," Tung Mason refers to the above passage about the distinguishing quality of a "true warfaring Christian" (607), arguing that the central thesis of the lengthy argument for the freedom of the press is none other than that truth can be maintained and virtue strengthened by one who is pure within, one who comes to grips with evil and yet refuses to be tainted. Although this is a plausible argument in terms of the profound role of the individual here, the crucial element of the public space should not be forgotten. The critical qualities Milton attaches to his concept of the true Christian (fit reader) underline the complexity and difficulty of the task. It is a mental war or trial in which one is radically challenged and through which one can acquire true virtue and purity.

Areopagitica addresses the Parliament claiming to provide an understanding of the situation and problem in the form of public "advice." Milton differentiates his own address to the Parliament from public flattery, praising, or other kinds of uncritical addressing, arguing that the commonwealth government, unlike other states that are delighted by flattery, welcomes public advice and accepts it as a form of praise. He asserts:

For he who freely magnifies what hath been nobly done, and fears not to declare as freely what might be done better, gives ye the best covenant of his fidelity; and that his loyalest affection and his hope waits on your proceedings. His highest praising is not flattery, and his plainest advice is a kind of praising. For though I should affirm and hold by argument, that it 
would fare better with truth, with learning, and the Commonwealth, if one of your published orders which I should name, were called in, yet at the same time it could not but much redound to the lustre of your mild and equal government, when as private persons are hereby animated to think ye better pleased with public advice, then other statists have been delighted heretofore with public flattery. (928)

To Milton, there are invaluable benefits and advances in public advice - advice both from the public to structures of power in society and advice given in public in different forms, namely, publication form - for the revelation of truth, learning, and the whole commonwealth. His own practice of addressing the Parliament is a singular example of a free declaration for the sake of truth. Areopagitica is a radical endeavour to question a law passed by the Parliament, asking for it to be re-examined and abolished because of the way it would place severe limits on what could be published in the new public space created by print. Milton's public advice demonstrates common features and qualities with Derrida's notion of the radical critique of powers. His emphasis on the public right to address the state in a radically critical and direct way, and the necessity of tolerance on the part of the state so that knowledge and learning can advance approaches the critical spirit of deconstruction. Public advice and a public space in which to share and publish it are indispensible in a democratic society.

In his essay, "Areopagitica, Censorship, and the Early Modern Public Sphere," in The Administration of Aesthetics, David Norbrook argues that after 1620 and during the 
parliamentary crisis in England a "significant expansion of the public sphere" happened in the society. He suggests that we can envisage Milton in Areopagitica supporting Habermas's theory of public space as a space of genuine communication and debate between members of the bourgeoisie educated in critical and informed interpretation. Although Norbrook's argument and his emphasis on Habermas's notion of public space suggest similarities, my argument demonstrates the radical, unconditional, and individualistic side of Milton's public space. Speaking as performance or verbal dialogue rather than as the assertion of authority or power constitutes the crucial part of Milton's radical critique. In Areopagitica, he stands up as a voice speaking publicly to contemporary democratic minds. In the next chapter, I will argue that Milton, in Eikonoklastes, conducts a public dialogue with the executed King, foregrounding the fundamental components of radically critical and free reading.

\section{The Parliament without Conditions}

Milton indicates that a free public space in which intellectual work is possible is indispensible and in line with human nature and God's will, a public space within which everything can be stated in different forms of publication and communication without conditions. Each human possesses free will to read, reason, choose, and acquire the knowledge of good and evil.

Since therefore the knowledge and survey of vice is in this world so necessary to the constituting of human virtue, and the scanning of error to 
the confirmation of truth, how can we more safely, and with less danger scout into the regions of sin and falsity then by reading all manner of tractates, and hearing all manner of reason? And this is the benefit which may be had of books promiscuously read. (939)

A publishing industry must be supported rather than obstructed by the state power. A free public space in the city must be guaranteed and supported by the Parliament rather than blocked and delimited. The Parliament must "advance the public good." Milton argues that if his writing delights those "who wish and promote their country's liberty" (928). Milton argues that "The utmost bound of civil liberty" is when complaints "are freely heard, deeply considered, and speedily reformed" (928).

Yet God commits the managing so great a trust, without particular Law or prescription, wholly to the demeanour of every grown man [...] For those actions which enter into a man, rather then issue out of him, and therefore defile not, God uses not to captivate under a perpetual childhood of prescription, but trusts him with the gift of reason to be his own chooser; there were but little work left for preaching, if law and compulsion should grow so fast upon those things which heretofore were governed only by exhortation. (938)

Milton calls for the Parliament to be the defender of truth rather than its enemy. For Milton, the Parliament is the democratic government that should not surrender to the 
autocratic use of power previously characteristic of the King; it must act for the benefit of the whole people. The Parliament must be an independent institution that is not conditioned by any established power (except the power of the public) and act to establish and maintain a public space supporting the liberty of intellectual work. It has to guarantee the manifestation of truth. Its profession is to act towards truth without conditions, presuppositions, or prescriptions. The Parliament professes the truth and must acknowledge its responsibility to provide a free public space in society dedicated to the ongoing process of the defragmentation of truth. Milton refers to economical terms of selling and buying in relation to the independence of the Parliament even when he is talking about the Presbyterians and other politico-religious powers. This line of argument has similarities with Derrida's emphasis on the university's independency from the marketplace, and the financial powers of society.

Milton represents his argument in a context that falls within the history of the "modern university" which is the object of Derrida's critique. What Milton claims for the freedom of the press and printing - which subsequently finds its appropriate addressees and context in the eighteenth century, especially in America and France ${ }^{29}$ - becomes an integral part of the complex intellectual and political process that led to the development of today's democratic societies. Milton's argument can be regarded as protodeconstructive, an identification that affirms the continuity between Milton's and Derrida's mode of thinking about the relation between critique and democracy. Milton

\footnotetext{
${ }^{29}$ See John Rumrich's introduction to Areopagitica in The Complete Poetry, especially page 924. For more on this discussion, see Kemmer Anderson's essay "Those Tenured Tyrants" in Milton in France.
} 
reminds us that the revelation of truth will be possible only if we have faith and trust in human ability to read and write freely and obtain the knowledge of good in order to contribute to the continuous process of defragmenting truth. Such a work is grounded in the individual's reason and conscience, and in exchange with others in a public space without conditions. His urge to assist the defragmentation of truth by publishing his arguments and contentions has close links to what Derrida refers to as "an appeal in the form of a profession of faith: faith in university and, within the university, faith in the Humanities of tomorrow" ("The Future of the Profession" 233).

Both Milton and Derrida address the question of freedom of intellectual work, the question of truth and justice, and the question of man and what is proper to man. Derrida speaks of an academic place, the unconditional university, within which there should be "an unlimited commitment to the truth." Milton similarly addresses the Parliament as an institution in which the truth should be defended and faithfully supported for the good of the people. Both writers recognize the lack of absolute knowledge and truth in the world. For Derrida, the truth has no absolute pre-existent form. For him, the history of truth is the story of history itself with no ending or completion. For Milton, truth pre-exists history, but once in history after the Fall the task of human intellectual work is to recover that truth. The effect is the same because both writers place this work in a future-oriented context of critique carried out in a free, unconditional public space of enquiry. 
Chapter Three

\section{Justice: Neither of Law nor as Law, but beyond Law}

In Chapter One, I attended to the question of singularity and exemplarity, examining the significance of context and situation in relation to admirable figures like Nelson Mandela and Abdiel. As fit readers, they radically encounter and question the laws and conventions of their society and act on the basis of the law of good conscience and justice to come. Chapter Two discussed the indispensability of free public space without conditions for intellectual work and the revelation of truth in the world. This unconditional public space needs the support of an independent institution as the guarantor for opening up the space (the university for Derrida and the Parliament for Milton) in which and because of which the right to say everything and radical critique become possible.

Milton's Eikonoklastes is a singular example of the radical critique of the question of law and justice in reading and responding to King Charles's book, Eikon Basilike. Radical critique takes place within the interval between law and justice. In order to make a true decision, laws must be always revisited, questioned, and reinvented; otherwise, there will be only calculations. In Eikonoklastes, Milton calls for an ongoing radical critique of the law as such and all its social-political embodiments (leaders, kings, and other power structures). This is the radical critique of the power structures which takes place in the revolutionary, problematic moment/space of decision between 
law and justice which Derrida calls the moment of aporia. This is the moment when the law (the calculable) is suspended, re-examined, and redefined and moves towards the incalculable (undeconstructible justice), and ultimately towards a decision which opens up the possibilities in the society for democracy and humanity to come.

The focus of the discussion in this chapter will be to attend to the question of the fit reader in Eikonoklastes by exploring the questions of law and justice and their problematic relations. I will argue that Milton's model of reading is clear and explicable in his works, particularly in Eikonoklastes, when we examine it in terms of the question of law and justice. My contention is that, like Derrida, Milton considers the law as deconstructible, calculable, and reducible, whereas justice is undeconstructible, irreducible, and incalculable for him. The experience of the undecidable interval between law and justice is absolutely essential for individuals in a society if they are to become fit readers, make just decisions, and act accordingly. Fit readers examine radically and critically the established laws, conventions, and norms of the society in which they live, but they decide according to the very law of their good conscience and reason and take absolute responsibility for that. Milton's model of reading, I will argue, is radically critical and free.

Critics writing on Milton's prose tract Eikonoklastes have identified it as an attempt to break down or destroy the image of Charles I as a martyr or saint which was 
successfully established by Eikon Basilike. ${ }^{30}$ Most critics agree on Milton's iconoclastic purpose in Eikonoklastes, however, the question is whether this is the primary purpose of the work. ${ }^{31}$ In this book, Milton exemplifies his intended reading approach and demonstrates the way one can become a fit reader. Several recent studies of Eikonoklastes have examined Milton's notion of fit reader and the dimensions of his model of reading in this book. ${ }^{32}$ For instance, David Ainsworth in the third chapter of his book, Milton and the Spiritual Reader, underlines "the role of spiritual and sacred reading" (34) in Eikonoklastes. He broadly defines the notion of "spiritual reading" in his book as "a process of critical reading that prioritizes spiritual concerns and sacred truths over worldly philosophy and politics; in Milton's case, the Holy Spirit in each believer serves as ultimate arbiter and authority" (34). Ainsworth contends that, in Eikonoklastes, Milton puts the theory of Areopagitica to work and engages in his own textual "trial" (34) because he has already addressed the Parliament in Areopagitica, asserting "that which purifies us is trial, and trial is by what is contrary" ( The Complete Poetry 939).

\footnotetext{
${ }^{30}$ See Laura Lunger Knoppers' "Historicizing Milton" in Achievements of the Left Hand; Achsah Guibbory's "Charles's Prayers" in Of Poetry and Politics; Elisabeth M. Magnus' "Originality and Plagiarism" in Areopagitica and Eikonoklastes, Laura Blair McKnight's "Crucifixion or Apocalypse? Refiguring the Eikon Basilike," in Religion, Literature; the third chapter in David Ainsworth's book, Milton and the Spiritual Reader, and Barbara K. Lewalski's "Milton and Idolatry."

${ }^{31}$ See Lana Cable's "Milton's Iconoclastic Truth" in Politics, Poetics, and Hermeneutics in Milton's Prose. 135-51.

${ }^{32}$ For discussions on the revolutionary political dimensions and ends of Milton's particular reading, see Sharon Achinstein's Milton and the Revolutionary Reader.
} 
Eikonoklastes was not as successful and influential as the King's book which went through thirty-five English printings in 1649. ${ }^{33}$ David Ainsworth argues that, in Eikonoklastes, Milton "pursues purposes beyond the merely propagandistic, and his work is particularly successful as a demonstration of critical and discerning reading, an educative polemic crafted to provide a select audience with the tools to resist Charles's propaganda" (33). He argues that, as propaganda, Milton's work failed, but its "failure is also its success" (58), which means that unlike Eikon Basilike, it does not offer the "comforts of father/king/God" (58) but it "places responsibility, struggle, and difficulty"(58) directly in the hands of its fit readers. Eikonoklastes enacts Milton's argument in Areopagitica that "bad books [...] to a discreet and judicious Reader serve in many respects to discover, to confute, to forewarn, and to illustrate" (34).

My argument here is to extend further Ainsworth's emphasis on the implications of becoming "spiritual, discerning readers" by engaging Milton's thought with Derrida's in the areas of the questions of justice and law. As a result of engagement with Derrida's thoughts, I will be able to delineate more fully the attributes and qualities of Milton's fit reader and his critical model of reading. In Eikonoklastes, I will be arguing, Milton considers law as calculable and reducible whereas justice is irreducible and incalculable. The paradoxically problematic situation between law and justice creates a breathtakingly difficult situation for people of the same society. For Milton's fit

\footnotetext{
${ }^{33}$ For a detailed discussion about the inadequacies of Eikonoklastes and the assumption that it was not successful because it lacked the essential propaganda that Eikon Basilike enjoyed, see Jane Hiles's "Milton's Royalist Reflex" in Spokesperson Milton: Voices in Contemporary Criticism, and Thomas N. Corns's Uncloistered Virtue : English Political Literature.
} 
reader/audience, the experience of such an aporetic moment/space is indispensible; a symbolic trial out of which they must be able to find their way and judge/decide truly and justly. The King's execution created such an undecidable interval/trial for the people. In Eikonoklastes, Milton practically demonstrates his model of reading through the practice of which people could attempt to discern the truth and identify justice. I will argue that his model of reading is radically critical and free, which does not bend to a particular approach with limited religious, political, or philosophical perspectives. It is an inclusive critical exploration of everything within the aporetic moment/space of intervals/trials between law and justice.

\section{Enforceability and Applicability of Law and Justice}

Derrida starts his argument in his essay "Force of Law" by arguing that the title of the conference "Deconstruction and the Possibility of Justice" brings together "words, concepts, perhaps things that do not belong to the same category" (231). ${ }^{34}$ The main terms here are justice and deconstruction, but there are also the crucial, related terms of "force" and "violence." The force of law and the force of justice have connections with what Derrida foregrounds as the force of deconstruction. He argues that there is always

\footnotetext{
${ }^{34}$ In his interview with Michel Rosenfeld, Derrida indicates that his interest in the question of law started "as it pertains to literature [with] [...] the legal constrains that have to do with the name of the author, the copyright, etc" ("An Interview with Jacques Derrida"). This interest primarily appeared as an essay on Kafka's parable "Before the Law" with the same title (in Acts of Literature). Later, Derrida wrote the essay "The Law of Genre" (in Acts of Literature) in which the major focus is on an inquiry into law and convention in literature. His explicit preoccupation with the question of law and justice in connection to deconstruction appeared as the lengthy influential essay "Force of Law" presented at a conference held by the Cardozo Law School in October, 1989 under the title "Deconstruction and Possibility of Justice."
} 
a force in law. The force "comes from within" law even though law itself is authorized and justified by this force. In his account of the phrase "to enforce the law," Derrida indicates that ''applicability' or 'enforceability,' is not an exterior or secondary possibility that may or may not be added as a supplement to the law. It is the force essentially implied in the very concept of justice as law, of justice as it becomes law, of the law as law" (233, his emphasis). It is language that generates the force of law. The law as letter brings force with itself and has force in itself. "The question of language and idiom," Derrida states, "will doubtless be at heart of" his discussion of the question of law and justice. He indicates that the word enforceability refers us to "the letter."

If the force of law plays an important role in constituting law as law, what would be the relation between justice and force? Can we think of justice other than as law and yet still enforceable? Is it possible to have justice without force? Derrida argues that, like law, justice is nothing without force. The force is the force of language, 'the exercise of force in language." He states that the expression "to enforce the law:"

[...] reminds us that if justice is not necessarily law or the law [Ie droit au la loi], it cannot become justice legitimately or de jure [de droit au en droit] except by holding [detenir] force or rather by appealing to force from its first moment, from its first word. At the beginning of justice, there will have been logos, speech, or language, but this is not necessarily in contradiction with another incipit, which would say, "In the beginning there will have been force." What must be thought, therefore, is this exercise of force in 
language itself, in the most intimate of its essence, as in the movement by which it would absolutely disarm itself from itself. (237-38, his emphasis)

The question of language is associated with the question of law, rights, and justice. For example, one must be aware of rights and laws in the language one is judged with. A person subject to judgment must be competent in "the language in which the law is inscribed or the judgment is pronounced" (246) because otherwise pronouncing judgment would turn into the exercise of violence. Derrida argues that there are many examples of situations of this kind in history "in which a person or group of persons assumed to fall under the law [Loi] are judged in an idiom they do not understand, not very well or not at all" (246). However, there is an important question here: is it possible to reach the perfect, ideal situation in which the highest level of competency of language is accomplished? Derrida's answer is negative. We are unable to address ourselves "to the other in the language of the other" because, Derrida argues, the only possibility of the use of the language of the other is through appropriation and assimilation of that language and according to the law of "an implicit third" through which "the universality or singularity of the idioms" (245) is suspended. In other words, there is no chance to achieve a perfect possibility of justice in any language because the language itself does not allow any complete level of competency and understanding. There will always remain some level of incompetency in language which is always the ground and possibility for the violence and injustice of language. The possibility of justice is impossible to this extent although possible in some imperfect form. 


\section{The Mystical Foundation of Authority of Law}

In order to discuss the distinction between justice and law Derrida, like Montaigne and Pascal, centres his argument on the expression "the mystical foundation of authority." He quotes Montaigne's argument that laws "are now maintained in credit, not because they are just, but because they are laws" (239-40). Montaigne believes that the mystical foundation of the authority of laws is grounded on the credit given to them. Derrida contends:

Clearly Montaigne is here distinguishing laws [lois], that is to say law [droit], from justice. The justice of law, justice as law is not justice. Laws are not just in as much as they are laws. One does not obey them because they are just but because they have authority. The word credit carries all the weight of the proposition and justifies the allusion to the mystical character of authority. The authority of laws rests only on the credit that is granted them. One believes in it; that is their only foundation. This act of faith is not an ontological or rational foundation. (240, his emphasis)

There is no foundation for law except "this mystical foundation of authority." The adjectives Derrida uses in his argument on the foundation of the authority of law are "mystical, not ontological, not rational" which, along with expressions like "masked power" or "certain lawful fiction," indicate the lack of a foundation for the law. Laws have a mystical, non-rational (not irrational), non-ontological foundation which is more 
like a non-foundation. Attempts have always made to identify and ground laws on justice to guarantee their legitimacy and authority; however, as far as the legitimacy and the authority of law is concerned, there is no justice as its foundation or origin. There is an authority in law that enforces it to us. The obedience to law has nothing to do with its justness. Derrida argues that, ontologically and rationally speaking, there is no foundation or origin for this force and authority. It is all a matter of letter and language. The performative act of calling something a law gives a credit to the law that generates, authorizes, and enforces the authority of law. This act of faith is the only foundation for law.

To explain the "mystical foundation of authority," Derrida quotes Montaigne's statement that "[and our law hath, as some say, certaine lawfull fictions, on which it groundeth the truth of justice]" (240). The crucial question here is the "lawful fictions" of law as the truth of justice. Montaigne's proposition, Derrida argues, is that there is a deficiency in nature which calls for "the supplement of artifice" that, in the absence of natural law, has provided the supplement of positive (fictional) law. For that reason, because fiction is "necessary to found the truth of justice," it is necessary to acknowledge the fictional foundation of law. Pascal's argument in this regard is different. Derrida argues that in "its principle, the Pascalian critique refers back to original sin and to the corruption of natural laws [lois] by a reason that is itself corrupt: '[Doubtless there are natural laws; but good reason has corrupted all]'” (241). Derrida's argument is as follows: 
Yet, the operation that amounts to founding, inaugurating, justifying law, to making law, would consist of a coup de force, of a performative and therefore interpretative violence that in itself is neither just nor unjust and that no justice and no earlier and previously founding law, no preexisting foundation, could, by definition, guarantee or contradict or invalidate. No justificatory discourse could or should ensure the role of metalanguage in relation to the performativity of institutive language or to its dominant interpretation. (241, his emphasis)

For Derrida, the only foundation of law is force, violence, power, a coup de force. There is always a linguistic, interpretative, performative violence in the very moment of founding law. This instituting force or violence is undistinguishable because it is neither just nor unjust. The core issue is that there is always "a call for faith" in "the very emergence of justice and law." At this very moment, the relation between law and force is singularly problematic and complex. This is not the time to speak of legal or illegal, just or unjust. At this moment, it is impossible to call what founds the law violence, force, or power. Derrida argues that this state of affairs goes beyond just/unjust or legal/illegal oppositions within the framework of which violence is to mean illegitimate and unjust force. At this singular moment, he asserts, discourse "meets its limit - in itself, in its very performative power" (242). The moment of founding law is what he calls the mystical. He asserts: 
There is here a silence walled up in the violent structure of the founding act; walled up, walled in because this silence is not exterior to language. [...] Since the origin of authority, the founding or grounding [la fondation ou le fondement], the positing of the law [Ioi] cannot by definition rest on anything but themselves, they are themselves a violence without ground [sans fondement]. This is not to say that they are in themselves unjust, in the sense of "illegal" or "illegitimate." They are neither legal nor illegal in their founding moment. They exceed the opposition between founded and unfounded, or between any foundationalism or antifoundationalism. (242, his emphasis)

Although this founding moment remains the only foundation of the authority of law, one can only think of it as an always mysterious, mystical, undecidable, unrecognizable moment, which generates a foundation that moves, transforms, justifies, and performs in the most unthinkable, complicated way.

\section{Deconstructible Law but Undeconstructible Justice}

In Derrida's argument, law is referred to as essentially deconstructible, calculable, and reducible because, first, it is founded on "interpretable and transformable textual strata," (242) and, second, "its ultimate foundation is by definition unfounded" (242). Of course, Derrida reminds us that the deconstructability of law is not "bad news." That law is based on textual layers that can be questioned and interpreted means that it has a 
potentiality for being transformed and deconstructed, "sometimes [towards] its amelioration." For Derrida, the history of law has been always about its deconstruction and changes that have contributed to a better future. This paradoxical deconstructive structure of law is even what "also ensures the possibility of deconstruction" (243).

It is perhaps because law (which I will therefore consistently try to distinguish from justice) is constructible, in a sense that goes beyond the opposition between convention and nature, it is perhaps insofar as it goes beyond this opposition that it is constructible - and so deconstructible and, better yet, that it makes deconstruction possible, or at least the exercise of a deconstruction that, fundamentally, always proceeds to questions of law and to the subject of law. (243)

Derrida differentiates between law and justice. He argues that the usual concept of justice is as the justice of law or justice as law, not justice in itself, even though the only way to imagine the difference is through law. Justice is a possibility. In Derrida's thought, justice "in itself, if such a thing exists, outside or beyond law, is not deconstructible. No more than deconstruction itself, if such a thing exists. Deconstruction is justice" (243, his emphasis). Law can be experienced in a definite way but justice is "the experience of the experience of what we are unable to experience" (244). Law is calculable but justice is incalculable. The experience of justice is "aporetic," improbable, and indispensible. Aporetic experience is the experience of moments "in which the decision between just and unjust is never insured 
by a rule" (244, his emphasis). Justice is always outside legal and institutional laws and beyond just/unjust oppositions. When identification of a law/rule as just or unjust becomes impossible, that is the very moment of justice because there is no rule which can determine the difference. Derrida argues that "I want to insist at once to reserve the possibility of a justice, indeed of a law [loi] that not only exceeds or contradicts law but also, perhaps, has no relation to law, or maintains such a strange relation to it that it may just as well demand law as exclude it" (233).

\section{Exteriority, Superiority, and Singularity of Justice}

In Derrida's thought, justice is exterior and superior to law. Unlike law that is appealed to for its general or universal applicability, justice is singular and deals with "the singularity of the other." For him, justice has always a singular idiom. It is irreducible to the established laws, rules, and principles of a society. He argues:

[...] justice, as law, seems always to suppose the generality of a rule, a norm, or a universal imperative. How to reconcile the act of justice that must always concern singularity, individuals, groups, irreplaceable existences, the other or myself as other, in a unique situation, with rule, norm, value, or the imperative of justice that necessarily have a general form, even if this generality prescribes a singular application in each case? 
In "Force of Law," Derrida contends that the question of justice and the desire for justice are at the heart of deconstruction. Deconstruction has not invented the activity of justice; it has been always already at work in law and all history. Justice as an energy is always transformational and evolutionary. It is an affirmative force in everything and evades any universal description or definition. Justice always preserves its mysticality and singularity. For Derrida, the "idea of justice" resists the assimilation by any wellknown messianicity, for instance, Jewish, Christian, Marxist, or post-Marxist. Although there is always a promise in such horizons, he argues, they are merely "types" and without absolute irreducibility and singularity. However, the idea of justice is different from all these conventional promises and might be "the very thing that, as one also says, 'keeps us moving [faint courir]' stronger and faster - for example, deconstruction" ( ). The idea of justice is:

[...] infinite, infinite because irreducible, irreducible because owed to the other - owed to the other, before any contract, because it has come, it is a coming [parce qu'elle est venue], the coming of the other as always other singularity. Invincible to all skepticism, as one can say by speaking in the manner of Pascal, this "idea of justice" seems indestructible in its affirmative character, in its demand of gift without exchange, without circulation, without recognition or gratitude, without economic circularity, without calculation and without rules, without reason and without theoretical rationality, in the sense of regulating mastery. (254, his emphasis) 
The characteristics Derrida ascribes to justice frustrate any form of simplification or clarification. The singular, infinite idea of justice "is not," but it "is coming;" it is in the sense of becoming not being. Derrida's use of phrases, starting with the negative proposition "without," allows no conventional form for its identification. This is close to "perhaps another kind of mysticism," Derrida states. Encountering this inaccessible "something" throughout history, humans have always come to the point of unreachability and unreadability even though there have been persistent attempts to represent this "mystical" something in some form. Derrida reaches the same point but he does not try to represent it in any way because he believes it is unrepresentable and remains always mystical.

\section{Deconstruction and the Possibility of Justice}

In "Force of Law," Derrida argues that, although a threat to law, deconstruction can bring about the condition of the possibility of justice. The crucial question is the connection between deconstruction and the possibility of justice. He asserts that the suffering of deconstruction "is perhaps the absence of rules, of norms, and definitive criteria to distinguish in an unequivocal manner between law and justice" (231). The struggle is to distinguish between law and justice "in an unequivocal manner." Deconstruction does not bend to any criteria and it is against its very method (in fact its non-method) to submit to the hegemonic nature of law. It is the radical critique of social-political hegemonies, powers, and institutions. To appeal to a definitive criterion means giving credit to law over justice. To distinguish them in an "unequivocal 
manner" is impossible because as soon as you choose your criteria, you allow the appropriation of your argument by the hegemony of that law. The discourse of that specific law appropriates the language of your argument and cause the secondariness of justice. The problem of deconstruction is its lack of laws, norms, or any alternative criteriology. Deconstruction judges by questioning "what judgment itself authorizes" (231). It questions the very rules of judging.

Referring to his previous essays like "Violence and Metaphysics," "Before the Law," or "The Laws of Reflection," Derrida maintains that he has been foregrounding the theme of justice in his works at least "in an oblique fashion." He insists that deconstruction "only apparently" has not addressed justice, ethics, or politics: "It goes without saying that discourses on double affirmation, the gift beyond exchange and distribution, the undecidable, the incommensurable or the incalculable, on singularity, difference, and heterogeneity are also, through and through, at least oblique discourses on justice" (235). He argues that one cannot speak of the singular, the incalculable, and the undecidable in a direct language and not to risk reducing them to the general, to norms or rules. To speak of the irreducible singular justice, "one cannot speak directly about justice, thematize or objectivize justice, say 'this is just;' and even less 'I am just;' without immediately betraying justice, if not law" (237). A direct discourse points at objectivisation and betrays the singularity of justice. Justice will never submit to an idea, theme, or reducible doctrine, legal, political whatsoever. It will be always on the way to come as the singular. 
Derrida claims that the possibility of justice in its imperfect but essential form is possible only by deconstruction. Deconstructive questioning deconstructs "the partitions that institute the human subject" and reinterprets "the whole apparatus of limits within which a history and a culture have been able to confine their criteriology" (247). Deconstruction has a double movement: 1) a responsibility in the sense of without limits and 2) a responsibility in the sense of a radical irresponsibility. Deconstruction has the unconditional responsibility of "recalling the history, the origin and the sense, thus the limits, of concepts of justice, law [Loi] and right [droit $]$, of values, norms, prescriptions that have been imposed and sedimented there, from then on remaining more or less readable or presupposed" (247-48). Derrida insists that this responsibility is not "only a philologico-etymological task or a historian's task but a responsibility in face of a heritage" (248). He contends that deconstruction is embroiled in the demand for infinite justice, which imposes a responsibility which would appear to be a radical irresponsibility because it involves suspending all of a society's accepted forms of responsible thought and action. Derrida argues that this responsibility is before memory or before the very concept of responsibility. This is the moment in which everything is suspended. The unconditional, radically irresponsible task of deconstructive questioning creates this moment, "this period of epoche, without which there is, in fact, no possible deconstruction" (248). Deconstruction is the possibility of justice and this moment is the very moment of justice:

It is not a simple moment: its possibility must remain structurally present to the exercise of all responsibility if such responsibility is never to abandon 
itself to dogmatic slumber, and therefore to deny itself. From then on, this moment overflows itself. It becomes all the more anguishing. But who will claim to be just by economizing on anguish? This anguishing moment of suspense also opens the interval of spacing in which transformations, even juridico-political revolutions, take place. It cannot be motivated, it cannot find its movement and its impulse (an impulse that, however, cannot itself be suspended) except in the demand for an increase or a supplement of justice, and so in the experience of an inadequation or an incalculable disproportion. (248-249)

Derrida argues that the metaquestioning of deconstruction starts "by destabilizing or complicating the opposition between nomos and physis, between thesis and physis - that is to say, the opposition between law [loi], convention, the institution on the one hand, and nature on the other, with all the oppositions that they condition" (235, his emphasis). It is, therefore, "through and through a questioning of law and justice, a questioning of the foundations of law, morality, and politics" (235). For Derrida, the performative act of questioning should not remain enclosed in purely speculative, theoretical, academic discourses, but:

[...] to aspire to something more consequential, to change things and to intervene in an efficient and responsible (though always, of course, in a mediated way), not only in the profession but in what one calls the city, the polis, and more generally the world. Not to change things in the no doubt 
rather naive sense of calculated, deliberate, and strategically controlled intervention, but in the sense of maximum intensification of a transformation in progress. (236, his emphasis)

Deconstructive meta-questioning aims to change things in the world. It facilitates and contributes to the force of language, the force of law and its paradoxes, and is always at work in institutional discourses. In the interminable transformation process of law, deconstruction attempts to release more and more of the paradoxical forces within law that in turn might introduce further justice to our world. Derrida's advice to add to this transformation in progress and to justice is that "if it seems urgent to pay attention to this joint or concurrent development and to participate in it, it is just as vital that we do not confound largely heterogeneous and unequal discourses, styles, and discursive contexts" (237).

\section{Experience of Interval/Aporia}

In his essay, referring to the title of the conference "Deconstruction and the possibility of justice," Derrida asserts that he must address "infinite problems" of the title in English which is related to the transitive use of the English verb "to address." To address a problem means "to go straight toward it and straight toward you, thematically and without detour" (243). The important point here is to find "a direct line of communication" (244). Derrida argues that the "infinite problems:" 
[...] are not infinite simply because they are infinitely numerous, nor because they are rooted in the infinity of memories and cultures (religious, philosophical, juridical, and so forth) that we shall never master. They are infinite, if one may say so, in themselves, because they require the very experience of the aporia that is not unrelated to what we just called the mystical. (244, his emphasis)

The infinite problems are the concepts of deconstruction, possibility, justice, and other related issues. Derrida argues that to address these problems is an experience of aporia because, if "experience" requires a path and a destination, the experience of aporia cannot be a full experience: "Aporia is a non-path and from this point of view, justice would be the experience of what we are unable to experience" (244). "Path" is symbolic of a predetermined way or method of travel or experience. Justice is the experience of aporia, an experience without and pre-programmed and predetermined method or way. Derrida contends:

But I believe that there is no justice without this experience, however impossible it may be, of aporia. Justice is an experience of the impossible: a will, a desire, a demand for justice the structure of which would not be an experience of aporia, would have no chance to be what it is - namely, a just call for justice. (244, his emphasis) 
Every time we apply a good rule to a particular case or example, according to a determinant judgment, Derrida argues, law is practiced and experienced, but justice is not. The aporetic moment/space between law and justice is when the suspension of law occurs and the impossible demand for justice becomes possible. Justice and deconstruction are the experience of the aporia or the impossible. It is in the moment/space of aporia that the difficult and unstable distinction between justice and law finds the chance to be recognised. Justice is "infinite, incalculable, rebellious to rule and foreign to symmetry, heterogeneous and heterotropic" (250), whereas law or the exercise of justice as law is statutory, calculable, regulated, and coded. In such a situation, "law claims to exercise itself in the name of justice and that justice demands for itself that it be established in the name of a law that must be put to work [mis en oeuvre] (constituted and applied) by force enforced" (251, his emphasis). The experience of aporia (deconstruction and justice) is the experience of the movement between these poles of justice and law. It is from this aporetic space that historical transformations of law, politics, and society can flow.

\section{Calculation and True Decision}

In "Force of Law," Derrida discusses the question of decision and calculation in relation to the distinction between law and justice in order to expound the moment/experience of aporia. He explains three aporias in relation to the moment of true decision-making. The aporia of "the Epokhe of the Rule" is one through which he accounts for the importance of freedom and responsibility in true decision-making. One 
needs to be both free and responsible to make a just decision. A decision cannot be just if it is not made freely. In addition, responsibility for a decision and its enactment is taken when there is freedom. However, Derrida argues that "this freedom or this decision of the just, if it is to be and to be said such, to be recognized as such, must follow a law [loi] or a prescription, a rule" (251). This is along with the fact that "if the act simply consists of applying a rule, of enacting a program or effecting a calculation, one will perhaps say that it is legal, that it conforms to law, and perhaps, by metaphor, that it is just, but one would be wrong to say that the decision was just" (251). A just decision is made in relation to a law but at the same time acts in its free nonprogrammable order. To be just one (a judge, for instance) must both follow a law and, "by a reinstituting an act of interpretation," reinvent and reinstitute it. There must be always a "fresh judgment" in the exercise of justice:

In short, for a decision to be just and responsible, it must [il faut], in its proper moment, if there is one, be both regulated and without regulation, it must preserve the law $[10 i]$ and also destroy or suspend it enough to have [pour devoir] to reinvent it in each case, rejustify it, reinvent it at least in the reaffirmation and the new and free confirmation of its principle. Each case is other, each decision is different and requires an absolutely unique interpretation, which no existing, coded rule can or ought to guarantee absolutely. ("Force of Law" 251) 
For a just decision to be just, it must be singular. Nelson Mandela's reinstitution of the law of equality and freedom in South Africa and Abdiel's decision to separate himself from Satan's army are among the most instructive instances of true and just decision. ${ }^{35}$ Nevertheless, paradoxically one cannot decide without reference to a law or rule. Derrida argues:

At no moment, it seems, can a decision be said to be presently and fully just: either it has not yet been made according to a rule, and nothing allows one to call it just, or it has already followed a rule - whether given, received, confirmed, preserved or reinvented - which, in its turn, nothing guarantees absolutely; and, moreover, if it were guaranteed, the decision would have turn back into calculation and one could not call it just. (253)

The second aporetic theme is "the Haunting of the Undecidable." Derrida argues that deconstruction (so, justice) is associated with the theme of undecidability; that is, the experience of that which must "deliver itself over to the impossible decision while taking account of law and rules" (252). He claims that a free decision is impossible unless it goes through "the test and ordeal of the undecidable," otherwise there would be only "a programmable application or the continuous unfolding of a calculable process" (252). However, to "go through" something indicates completion and achievement, which is problematic and impossible in deconstructive discourse. The ghost of the undecidable is something in every decision or in the event of a decision. A

\footnotetext{
${ }^{35}$ See my discussion in Chapter One.
} 
calculated decision, however lawful, carries with it the undecidables which it has suppressed, but in a true decision the undecidables' "ghostliness [sa fantomaticite] deconstructs from within all assurance of presence, all certainty or all alleged criteriology assuring us of the justice of a decision, in truth of the very event of a decision" (253).

The third aporia Derrida analyses is the urgency that obstructs the horizon of knowledge. For him, the moment of a just decision "must always remain a finite moment of urgency and precipitation" (255). In fact, one reason for keeping a distance from all "horizons" - different types of the messianic promise - is because they are only horizons and as the original Greek meaning of the term suggests it is "both the opening and the limit that defines either an infinite progress or a waiting and awaiting" (255). This meaning of "infinite progress or awaiting" is against the urgency required in justice. Justice "does not wait" and "must not wait." Derrida asserts:

[...] let us say this: a just decision is always required immediately, right away, as quickly as possible. It cannot provide itself with the infinite information and the unlimited knowledge of conditions, rules, or hypothetical imperatives that could justify it. And even if it did have all that at its disposal, even if it did give itself the time, all the time and all the necessary knowledge about the matter, well then, the moment of decision as such, what must be just, must (il faut] always remain a finite moment of urgency and precipitation [...]. (255) 
A just decision cannot be the result of the deliberation of the messianic promises because it "always marks the interruption of the juridico-, ethico-, or politico-cognitive deliberation that precedes it" (255). A decision that is the consequence of the theoretical and historical knowledge cannot be true decision. A complete mastery of knowledge and rules will never happen in the moment of decision; the moment of decision is a "madness." Derrida argues:

Even if time and prudence, the patience of knowledge and the mastery of conditions were hypothetically unlimited, the decision would be structurally finite, however late it came - a decision of urgency and precipitation, acting in the night of non-knowledge and non-rule. Not of the absence of rules and knowledge but of a reinstitution of rules that by definition is not preceded by any knowledge or by any guarantee as such [...]. (255-56)

The critical aspects of the aporetic moment/space which together define the conditions to make a just decision are freedom in relation to the law, undecidability which means that a just decision cannot be simply deduced from a law, and the urgent pressure for a decision. If any of the above conditions in the process of decision-making is not experienced, there would be only calculation and no decision. There will be justice only when a true decision is made. 


\section{Good Conscience and Justice to Come}

Derrida argues that the only way to say with certainty that I am just or a decision is just is "in the figure of good conscience and mystification" (248). To choose freely is to listen to the voice of your conscience without the force of laws. This is exactly what individuals like Nelson Mandela, Abdiel, the Son of God in Paradise Regained, and Samson do when they encounter the aporetic moment/space of decision-making. The force of law and the force of good conscience are fundamentally at work at the very moment of justice when the situation goes beyond the just/unjust opposition. Those who are on the side of justice and do justice to justice choose the law of their singular conscience in defiance of the laws and rules of institutions. "Good conscience" is the force through which one can address the question of justice and assert with confidence that "I am just or it is just." For Derrida, deconstruction imposes an infinite responsibility for questioning laws, norms, and origins with a good conscience. A good conscience takes priority over any determined or inherited law. He argues that justice "compels to denounce not only theoretical limits but also concrete injustices, with the most palpable effects, in the good conscience that dogmatically stops before any inherited determination of justice" (248).

Derrida's argument in "Force of Law" concludes with his discussion of the notion of justice to-come. Justice, for Derrida, has no horizon of expectation, but it has "perhaps an avenir," a "to-come." In the concept of expectation, there is a meaning of 
deliberation or predetermination. There is also a difference between the notion of the future and the to-come. Derrida argues:

Justice remains to come, it remains by coming [la justice reste à venir], it has to come [elle a à venir] it is to-come, the to-come [elle est a-venir], it deploys the very dimension of events irreducibly to come. It will always have it, this a-venir, and will always have had it. Perhaps this is why justice, insofar as it is not only a juridical or political concept, opens up to the avenir the transformation, the recasting or refounding [la refondation] of law and politics. (256-57, his emphasis)

The demand for justice to come represents itself in the form of desire and energy that would lead to the transformation, amelioration, and reinstitution of law; in fact, it is the cause of the history of law and history itself. Nevertheless, if justice is the to-come and never present, how can we think of and speak of the possibility of justice? Derrida asserts that "'Perhaps' - one must [il faut] always say perhaps for justice. There is an avenir for justice and there is no justice except to the degree that some event is possible which, as event, exceeds calculation, rules, programs, anticipations, and so forth" (257, his emphasis). No doubt, this is not to say that the overflowing of the unpresentable over the determinable cannot be used as an "alibi" to stay "out of juridico-political battles, within institutions or a state, between institutions or states" (257). Derrida warns us that if justice is "abandoned to itself," it is "re-appropriated by the most perverse calculation" like religious terrorism and fundamentalism. His direction is: 
But incalculable justice commands calculation. [...] Not only must one [il faut] calculate, negotiate the relation between the calculable and the incalculable, and negotiate without a rule that would not have to be reinvented there where we are "thrown," there where we find ourselves; but one must [il faut] do so and take it as far as possible, beyond the place we find ourselves and beyond the already identifiable zones of morality, politics, or law, beyond the distinctions between national and international, public and private, and so on. (257)

\section{Law, Godlike Justice, and Public Reason}

In Eikonoklastes, Milton addresses the distinction and relation between law and justice when he discusses the foundation of the law of the Parliament and the King's law. He refers to their arguments on the question of law and justice. They focus on the question of which has the greater authority, the law or the King's will. In his discussion, Milton considers the crucial relations between force and law, force and justice, force and the King, his people, and the Parliament. He argues that, as frequently acknowledged by King Charles I himself, he has "no right over us but by Law; and by the same law to govern us" (360). Milton claims that law must be universally applied, regardless of rank and position: "all Laws, both of God and Man, are made without exemption of any person whomsoever; and that if Kings presume to overtop the Law by which they reigne for the public good, they are by Law to be reduc'd into order" (592).The king's 
authority and his kingdom's legitimacy have been granted to him by the law by which he must also govern his people. To Milton, the King is not superior to the law of the State. He questions the King's claim that "Hee hoped by his freedom, and their moderation to prevent misunderstandings," (356, his emphasis) and argues that the King's so-called high reason or wisdom "came to him by Title, with his Crown" and what the King regards as the people's "Passion, and Prejudice [...] came to others by being Subjects" (356). His position or the authority of law has given him the title of high wisdom and reason. The King is submitted to because of his authority, and that authority is invested in him through the people. Milton argues that those "objected Oaths of Allegiance and Supremacy we swore, not to his Person but as it was invested with his Authority; and his authority was by the People first giv'n him conditionally, in Law and under Law, and under Oath also for the Kingdoms good, and not otherwise" $(592-93)$.

Milton argues that the King is subject to the law as any other men of the society: "Kings in receiving Justice, \& undergoing due trial, are not differenc'd from the meanest Subject" (594). In response to Charles' claim that "No Law of God or man gives to subjects any power of judicature without or against him," in Chapter 28 of Eikonoklastes, Milton writes that the Mosaic Law was given to all men. That law's provision that "whosoever sheddeth man's blood, by man shall his blood be shed," applies to kings as well as ordinary men. Milton comprehensively reviews historical figures and their cases, and argues for the idea that kings have been held accountable 
before, and if necessary, even executed ${ }^{36} \mathrm{He}$ concludes that there is nothing divine and exemplary about the King's wisdom. The question of the relation between the state (and its laws) and the people is well illustrated in this part of his argument. Milton attempts to break the sacred image of the King as the absolute source of justice and law by engaging in what much later Derrida names an act of deconstruction. David Ainsworth, in Spiritual Reading, writes that Milton:

[...] must dismantle image and book to replace the idolatrous image which the king presents with a less flattering image of the king. This deconstruction also breaks apart the false equation between civil and religious affairs, between Charles and Christ, which Charles presents to bolster his authority and position. By teaching his readers, through example, how to see through Charles's textual deceptions, Milton replaces an idolatrous method of reading with a critical and godly one. (44)

Milton's argument demonstrates that the law is a conception which can be questioned, reviewed, and challenged if the situation/context makes it necessary. He discusses the deconstructability of law and the foundation of the kingdom which derive its authority and credit from law and the people. In Chapter 27 of his book, Milton comments on Charles' advice to his son:

\footnotetext{
${ }^{36}$ See especially Chapter 28 of Eikonoklastes.
} 
His next precept is concerning our civil Liberties; which by his sole voice and predominant will must be circumscrib'd, and not permitted to extend a hands bredth further than his interpretation of the laws already settl'd. [. . .] if the removing of an old Law, or the making of a new would save the Kingdom, we shall not have it unless his arbitrary voice will so far slack'n the stiff curb of his prerogative, as to grant it us. (573, his emphasis)

Charles's desire is to prevent the questioning of his authority and to place his will above the law. His attempt is to forestall the deconstructability of law and, instead, anchor his own understanding and interpretation of the established laws as the only just and legitimate ones. Milton here demonstrates that the law as such is deconstructible and its interpretation must not be restricted to one person or group. Milton argues:

But freedom he thought too high a word for them; and moderation too mean a word for himself: this was not the way to prevent misunderstandings. He still fear'd passion and prejudice in other men; not in himself: and doubted not by the weight of his own reason, to counterpoyse any Faction; it being so easie for him, and so frequent, to call his obstinacy, Reason, and other men's reason, Faction. Wee in the mean while must believe, that wisdom [5] and all reason came to him by Title, with his Crown; Passion, Prejudice, and Faction came to others by being Subjects. (356, his emphasis) 
The foundation of "Law in a Free Nation hath bin ever public reason, the enacted reason of a Parliament" (360). Milton contends that the King does not surrender to this law or govern by it; instead, he rules with another law "which to us is no Law" (360). In Eikonoklastes, Milton emphasizes the superiority of the law (generated by "public reason") over the King; however, he never regards this law as absolute, incalculable or irreducible. Throughout his argument, he foregrounds the transformability and changeability of the law. He exclusively values a principle, which remains the most trustworthy source and foundation for law; that is, law as the expression of the agreed principles of the Parliament. The elected members of the Parliament represent the "Public reason" and make the laws.

In Milton's thought, the only legitimate authority has its roots in public reason. In "Counterfeiting and the Economics of Kingship in Milton's Eikonoklastes," Cohen Scott argues that just as "the coin is minted and stamped with the authoritative mark of the sovereign that signifies the value of the coin, the kingship is minted by the people, and they stamp the value of the king through their decree" (167). ${ }^{37}$ It is the credit or the faith of the people that produces the force of law. When the people endorse their representatives by their votes and they in turn act as a legislative body, the act of faith, or the credit given by the people, is transmitted into law and creates the force of it. This does not mean that the force of law comes from outside of it, but that the very moment of its establishment is the moment that law becomes law and its existence is

\footnotetext{
${ }^{37}$ See Cohen Scott's "Counterfeiting and the Economics of Kingship in Milton's Eikonoklastes" for an interesting discussion on the economics of kingship and public reason.
} 
simultaneous with its force. The performative act of language and the act of faith become the foundation of law and its authority. This act of faith or credit is nonontological. The act of the public reason, in Milton's argument, works through the performativity/force of language. For Milton, not only does the King's law have no unquestionable divine foundation as justice, but also his reason, wisdom, and will are not absolute and above law in any sense. Milton argues:

$[\ldots]$ his [the King's] resolution was $[\ldots]$ to set up an arbitrary Government of his own; and that all Britain was to be ty'd and chain'd to the conscience, judgment, and reason of one Man; as if those gifts had been only his peculiar and Prerogative, intal'd upon him with his fortune to be a King. When as doubtless no man so obstinate, or so much a Tyrant, but professes to be guided by that which he calls his Reason, and his Judgement, though never so corrupted; and pretends also his conscience. In the mean while, for any Parlament or the whole Nation to have either reason, judgment, [8] or conscience, by this rule was altogether in vaine, if it thwarted the Kings will; which was easie for him to call by any other more plausible name." (359)

Anyone or any group that tries to put themselves above the law of public reason defies the very nature of law. Milton reviews the history of law to proclaim that, first of all, kingdoms and kings have been subject to law throughout history and have never had superiority over it, and secondly, law has been the foundation for their authority and 
kingdom. The foundation of the law has been always built upon public consent and agreement in form of statement, the performative act of language. As long as this law has the support of public consensus, it is legal and just. Milton identifies law as the production of human interpretation based on different texts and institutional languages. He believes that God's justice and the Scriptures are the foundation for Christian laws, but the Scriptures have been corrupted by human interpretations. Ontologically, he affirms the existence of God and his justice as the origin of the universe and all the world's states and systems but, historically, he argues that human experience since the Fall has resulted in imperfect or corrupt forms of government. ${ }^{38}$

In the last chapter of Eikonoklastes, Milton addresses the question of justice, truth, strength, force, and violence. He argues that "truth and justice are all one" and are inseparable. Truth and justice will be nothing without one another. Justice belongs to the realm of practice, but truth is in the realm of knowledge, teaching, and thinking. Although Milton attributes different roles to truth and justice, he emphasizes that these two sources of strength and force cannot survive and remain influential without one another. Milton's answer to the question, which is the strongest, is justice and truth together; this is to company true knowledge, teaching, and contemplation (truth) with justice as the enactment of that knowledge. Milton metaphorically refers to the sword of justice, which refers to the force of justice, and disagrees with the scriptural example of Zorobabel, who reports the conclusion that "it was so yielded by the King himself, \&

\footnotetext{
${ }^{38}$ See Elizabeth Oldman's essay "Milton, Grotius, and the Law of War: A Reading of 'Paradise Regained' and 'Samson Agonistes."'
} 
all his sages, that neither Wine nor Women, not the King, but Truth, of all other things was the strongest" (583). Milton asserts:

For me, though neither ask'd, nor in a Nation that gives such re-[213]wards to wisdom, I shall pronounce my sentence somewhat different from Zorobabel; and shall defend, that either Truth and Justice are all one, for Truth is but Justice in our knowledge, and Justice is but Truth in our practice, and he indeed so explains himself in saying that with Truth there is no accepting of Persons, which is the property of Justice; or els, if there be any odds, that Justice, though not stronger then truth, yet by her office is to put forth and exhibit more strength in the affaires of mankind. For Truth is properly no more then contemplation; and her utmost efficacy is but teaching: but Justice in her essence is all strength and activity. (583-584, his emphasis)

In Milton's argument, the exteriority of justice to law is emphatically identified. Even though the law comes from public reason, justice still remains outside the legal system and never becomes identical to any law. This does not mean that a law and the judgment based on it cannot have just results and outcomes. It means that justice is not the same as law. Justice for Milton is unquestionable and performs itself through the agents and means "she" selects in various situations and contexts. Milton highlights the exteriority and superiority of justice over law and any position of power in the state: 
[...] and [Justice] hath a Sword put in her hand, to use against all violence and oppression on the earth. Shee it is most truly, who accepts no Person, and exempts none from the severity of her stroke. Shee never suffers injury to prevaile, but when falsehood first prevails over Truth; and that also is a kind of Justice don on them who are so deluded [...] yet shee communicates her power to none but such as like her self are just, or at least will do Justice. For it were extreme partialitie and injustice, the flat denyall and overthrow of her self, to put her own authentic Sword into the hand of an unjust and wicked Man, or so farr to accept and exalt one mortal person above his equals, that he alone shall have the punishing of all other men transgressing, and not receive like punishment from men, when he himself shall be found the highest transgressor. (584-585)

Unlike the laws of nations and states, justice is singular and against "all violence and oppression on the earth." Metaphorically speaking, Milton refers to an "impartially" singular and absolute justice when he writes that justice "accepts no Person, and exempts none from the severity of her stroke" (585). "Shee" chooses to put "her own authentic Sword" into hands like hers which are just. Considering the question of history in Milton's framework of thought, we can discern that a diversity of "hands" has been selected by justice among various groups, sects, and religions in history. Remembering Milton's stance on sects and factions in Areopagitica - that a hypocritical protestant can be totally unjust on the devil's side but an honest catholic on the side of justice - we can claim here that for Milton justice can be practiced and represented by 
any group or system of thought as long as that group or individual enjoys the truth and its aim is to do justice to all.

In the preface of Eikonoklastes, Milton censures and ridicules the Presbyterians for changing their stance concerning the trial of the King and for their withdrawal from supporting the King's execution. ${ }^{39}$ Milton believes that the execution has been the work of "the unsparing sword of justice" and those who changed their position have been always following "their own malignant designs" and were never truly in support of true religion and justice. He argues that those "[who] professed Loyalty and Allegeance" fought against the King which was not considered violence then, but now that he is being tried with "the Sword of Justice," they speak of "him violated." Here, Milton differentiates all these social-political instabilities of the sects and factions from true justice; that is to say, justice is other than all these different forms of "designs," “aspiring hopes," “ambitious purposes." Otherwise, he argues "Justice, whether moral or political, were not Justice, but a fals counterfeit of that impartial and Godlike virtue" (346). For him, therefore, justice may be manifested in the practices of the sects and factions, but it is not the property of any one. The emphasis on the impartiality of justice permits no exclusion or immunity. Furthermore, the identification of justice is entangled with its unidentifiability. That is, justice in itself is godlike and God's identity always remains beyond definition and identification as the unapproachable and undecidable. The limitless and non-definable spirit of justice in Milton's description is consistent with Derrida's idea of undeconstructible justice. Milton believes that not only

\footnotetext{
${ }^{39}$ See my argument in Chapter Four.
} 
is justice different from law but also it, "above all other things, is and ought to be the strongest" (585). For him, justice is superior to all, namely the civil laws, the laws of Church, the laws of states and governments, and even the laws of God: "shee is the strength, the Kingdom, the power and majestie of all Ages" (585).

Milton censures the justice of sects and groups who are against the King's trial and execution but he strongly supports those who are trying the King and refers to them as the holders of "the Sword of justice." Unlike Derrida who never sides with a method or strategy or structure, we see that Milton associates justice with the Parliament and their adherents. This siding seems against the irreducible spirit of deconstruction. However, the point is Milton does not fundamentally restrict the concept of justice to any specific group, faction, or system of thought. The sword of justice is not exclusively in the hands of a specific system, power structure, or group. If the Parliament and the King's execution are advocated for and defended by Milton on this occasion, it is the same parliamentary structure and its making a new law for licensing printing that must earlier bear his severest criticism in Areopagitica. As a fit reader, Milton makes extreme efforts to identify the practice of justice on all occasions during his life. Justice finds and selects its agents in different social-political bodies. Milton positions justice outside all frames and structures and thinks of it as a ghostly presence that would have effects in history/human experience. 


\section{Fit Reading and the Possibility of Justice}

At the beginning of Eikonoklastes, Milton argues that his response to the King's book, Eikon Basilike, is not because he is "after fame," but because he endeavours to destroy the false representation of the King imposed by Eikon Basilike upon the people. The enforcement is in the form of reading and interpretation. The intended effect of the King's book on people is to make them believe that he "breath'd not the same breath with other mortal men" (338). Milton's attempt to represent a truer image of the King and his actions "on the behalf of liberty, and the commonwealth" and destroy this idolized image would be of course in the realm of language, interpretation, and reading. Milton applies his method of radical, critical, and free reading in order to interpret and

judge truly and justly, a method which is founded in the qualities of language: "For in words which admit of various sense, the libertie is ours to choose that interpretation which may best minde us of what our restless enemies endeavour, and what wee are timely to prevent" (342). Milton insists that the achievements of language are more influential than the victories of armies. He makes the performative, interpretive force of language the very focus of his book:

[...] among other examples we finde that the last will of Caesar being read to the people, and what bounteous Legacies hee had bequeath'd them, wrought more in that Vulgar audience to the avenging of his death, then all the art he could ever use, to win thir favor in his life-time. And how much their intent, who publish'd these overlate Apologies and Meditations of the 
dead King, drives to that same end of stirring up the people to bring him that honour, that affection, and by consequence, that revenge to his dead Corps, which hee himself living could never gain to his Person [...]. (342)

To him the power of the King's book lies in its ability to change the conception of the king in the minds of the people. Referring to the Latin words written on the "portraiture" of Eikon Basilike, Milton indicates that the King or the ghost-writer hope that "what hee could not compass by Warr, he should achieve by his meditations" (342):

In one thing I must commend his op'nness who gave the title to this Book, Eikon Basilike, that is to say, The Kings Image; and by the Shrine he dresses out for him, certainly would have the people come and worship him. For which reason this answer also is intitl'd Iconoclastes, the famous Surname of many Greek Emperors, who in thir zeal to the command of God, after long tradition of Idolatry in the Church, took courage, and broke all superstitious Images to peeces. (343)

Milton publishes his book, Eikonoklastes, as an essentially deconstructive reading of the King's book which has created an exemplary image of the Christian King as a universal model blocking the critique of kings and state powers in general. Working on the minds of its readers, it aims to anchor and institutionalize monarchy in an undisputable and 
unquestionable form. The King is represented as a saint, a martyr, beyond critique..$^{40}$ This is exactly against the very practice of Milton's fit reading. Milton's radical, critical reading of Eikon Basilike is a good example of textual performative critique and its challenge to hegemonic language. His reading strategy is a form of deconstructive metaquestioning. Milton writes:

And if by sentence thus writt'n it were my happiness to set free the minds of English men from longing to returne poorly under that Captivity of Kings, from which the strength and supreme Sword of Justice hath deliverd them, I shall have don a work not much inferior to that of Zorobabel: who by well praising and extolling the force of Truth, in that contemplative strength conquer'd Darius, and freed his Countrey, and the people of God from the Captivity of Babylon. Which I shall yet not despair to doe, if they in this Land whose minds are yet Captive, be but as ingenuous to acknowledge the strength and supremacie of Justice [...]. (585)

Milton's aim in this book, which responds to an urgent political situation but is oriented towards the future, is to "free the minds of English men from returning to slavery and captivity." He believes that if people do not read and interpret the King's book correctly, they will lose their freedom. His own reading of the King's book is the very exemplification of a fit reading, which considers, questions, and analyzes everything in

\footnotetext{
${ }^{40}$ For a discussion on Milton's attempt to replace the image of the King as a saint or martyr with his own image of Charles, see David Loewenstein's Milton and the Drama of History: Historical Vision, Iconoclasm, and the Literary Imagination.
} 
order to come to a true and just understanding and judgment which provides the opening for justice. Milton's attempt, as Ainsworth indicates, is to put the theory of Areopagitica to work "in Eikonoklastes and engage in "textual trial'" (Spiritual Reading 34). His reading model is radical and critical enough not to exempt even the King as the highest religious and political power. Such a reading is to be free from all sectarian and customary interests and concerns. The textual trial in the form of radical, critical, and free reading, for Milton, is the only way through which individuals in his society could be able to identify the truth of a case and judge truly and justly for the sake of freeing all people from any hegemonic, tyrannical power and moving towards more justice. Susanne Woods, in her essay "Elective Poetics and Milton's Prose," argues for what she calls an "elective poetics" in Milton's polemical writings, which is "an author's method for requiring and empowering reader choice, often to get the reader to enact the liberating and self-defining process of choosing" (196). ${ }^{41}$

Milton makes regular disapproving references to readers of the King's book who are not demonstrating the attributes and qualities of being a fit reader. He calls such readers "the blockish vulgar," "the common sort," those with "boisterous folly and superstition," judging "without industry or the paines of well judging, by faction and the easy literature of custom and opinion," (339) and "prone ofttimes not to a religious onely, but to a civil kinde of Idolatry in idolizing their Kings" (343). In his thought, unfit readers "would shew themselves to be by nature slaves, and arrant beasts; not fitt for that liberty

${ }^{41}$ See Susanne Woods' essay, "Elective Poetics and Milton's Prose," in Politics, Poetics, and Hermeneutics in Milton's Prose. 
which they cri'd out and bellow'd for, but fitter to be led back again into thir old servitude"(581).

\section{The Experience of Trial/Interval}

In the civil war in the England of the 1640s and 1650s the King's execution must be considered a fundamentally critical and problematic moment. Radical attempts to interpret laws, norms, and principles connected to this issue are undertaken by various groups and parties. In this historical interval, the moment of trial, an enormously heterogeneous interpretative and performative event takes place - which is of more significance than its immediate result, the execution of the King. This moment is a moment of radical questioning, of deconstruction, and of justice. This aporetic moment opens to the experience of the impossible. The experience of such an aporetic moment/space is indispensible for becoming a fit reader when the questions of law, justice, violence, and force become fundamentally and problematically engaged and deconstructed.

The concept of "trial" for Milton demonstrates the severest conflict between law and justice. Like deconstruction, it offers both an extreme threat to the question of law and the very possibility of justice. Milton wrote his book after the execution of Charles I. The challenge was to justify the trial that led to regicide when people were reading the King's book. In Eikonoklastes, Milton attempts to re-create the trial for his readers on the symbolic level and exemplify the experience of such a radical and critical moment. 
In his essay, "'Fit Though Few:' Eikonoklastes and the Rhetoric of Audience," Daniel Shore asserts that Eikonoklastes "is the prime locus of Milton's concerns about the problems of reading and misreading, and concomitantly of being read and misread" (130). Milton argues that if one is to judge truly and justly as a fit reader, the experience of radically critical and free reading is absolutely essential. His approach to critiquing the King's book chapter by chapter in a conversational form is represented as a trial in which all the fundamental questions of law and justice are suspended and questioned. Milton believes that a just decision can be arrived at only if no laws or authorities even the King - are exempt from being questioned and critiqued. How radical this critique must be is demonstrated when he argues that typically there is a disconnect between divine and human authority: "If God then and earthly Kings be for the most part not several only, but opposite Masters, it will as oft happ'n that they who will serve their King must forsake thir God; and they who will serve God must forsake thir King" (581). Even the contract between the King and his people must be suspended.

In fact, the term "trial" for Milton in Eikonoklastes, does not primarily refer to the execution of a king or a tyrant, but it refers to the essential deconstructive metaquestioning of powers. The concept of trial is the performative act or the metaquestioning force of language by means of which Englishmen must confront the violence of the King's book. Milton welcomes trial as an aporetic moment/space within which the perpetual critique of tyrannical powers takes place. In Milton's thought, the constant experience of trial and radically critical and free reading are indispensible for identification of truth and justice. The questions of law and justice, in Milton's 
argument, are represented as fundamental in his response to Charles' claims. The King has challenged the law and put himself and his will above the law and the Parliament. If an absolutist system of thought, like the King's, endeavours to block the progressive nature of legal systems and institutions by claiming to be the sole source of unquestionable justice, the whole purpose of critique is to stand against such closure. One direct consequence in the specific context of the civil war is the trial and subsequent execution of the king. Just as deconstruction exploits the interpretative potentials of language to destabilize, reinterpret, and re-establish laws, and norms and principles, so Milton employs language in the same way to support the King's execution and argue against the tyrannical discourse of the King and his followers. The moment of King's trial is one which the laws and institutions of the state are unable to address. Regicide happens in the interval between the deconstructability of law and undeconstructability of justice.

\section{True Judgment/Decision and the Holy Spirit}

In seventeenth century language, Milton established a position for his fit reader in Areopagitica which affirms the necessity of the reader's access to an alternative authority. For him, this alternative authority is reason and conscience, supported and informed by the Holy Spirit. Milton's awareness that he is operating in a historical epoch where direct access to God's justice in human affairs does not exist underlines his rejection of the King's claim to divine authority for his actions. Reason and conscience for him, although fundamental, are not sufficient authorities for making true 
decisions/judgments. It is the Holy Spirit that informs the reason and conscience of the individual and authorises decisions. Urania in Paradise Lost plays such a role for the poet/narrator. ${ }^{42}$

The Holy Spirit's position and role in the divine structure is opposite to reason and law. The crucial aspect of the Spirit is that its operation is entirely unpredictable and follows no patterns, rules, or laws. The experience of the presence of the Holy Spirit is private and individual, which links such an experience to the singularity of the person's reason and conscience. In this sense, the Spirit, for Milton, can be a term for what Derrida refers to as the indeterminate, the undecidable, and the incalculable in an aporetic moment/space. The decisive feature of the Spirit is that it is impalpable and ineffable, entirely the opposite of institutions, forms, laws, or the calculable. The Holy Spirit emphasises the singularity of the person and demonstrates the way this singularity can be affirmed within a religious framework of thought. To Milton, the Holy Spirit is the source of ultimate authority experienced by a fit reader.

By critiquing the image of the ruler in Eikon Basilike and through conducting a trial of King Charles in Eikonoklastes, Milton openly explores the relationships between force, violence, law, and justice. One metaphor used in connection to justice is sword which stands for both the ultimate power of enforcement and detachability of justice from the judge or individual. He demonstrates that justice is holding the sword not the King in the name of justice. In Milton's argument, truth and justice come into the world through

\footnotetext{
${ }^{42}$ See my argument on the role of Urania in Chapter Five.
} 
human beings. In other words, any individual can claim to hold the sword of justice because they can develop the attributes and abilities required for having the spiritual authorization to implement justice in the world. Another reference to the singularity of human subject is when he accounts for the idea that the higher measure of justice must be applied to kings because of their higher responsibilities: "The unsparing sword of justice, which undoubtedly so much the less in vain she bears among men, by how much the greater and in highest place the offender" (preface). This could mean of course the possible violation of the laws and principles of a society's institutions and systems. The allegorical image of the sword of justice represents a deliberate detachment of the source of justice from any given position of authority. However, an individual/fit reader, according to Milton, must conceive in their reason and conscience a problematically unjust situation for the improvement of which they may act against the established laws and principles. Such a person acts according to a conviction that is grounded in reason and conscience, supported and authorised by some unpredictable, incalculable source. A singular authorization is absolutely required for Milton's fit reader to reach a true and just decision.

The relation between justice and the aporetic is crucial in Milton's argument. The radical social actions placed in individuals against official systems demonstrate the fundamental importance of the individual or fit reader for him. The unpredictability of the individual's action - when it is free from the constrains of the institutional authority of the church, state, family, and so on - is manifested in an aporetic moment/space in 
which a decision to act justly turns out to be a decision that is not predictable by any official institutions or established system of thought.

The question of justice, and its relation to conscience, is a dominant preoccupation in Milton's works. By dissociating justice from any office or function in the state, and associating it with God and the Holy Spirit, Milton emphasizes the singularity of justice and avoids reducing it to the general, to the application of law. The metaphor of "the Sword of Justice" supports a democratic interpretation when the hand holding the sword is not specified but is directed by reason, conscience, and the Spirit. For Milton, like Derrida, justice remains undeconstructible and superior to the law as such.

Milton believes that all human affairs lack final resolution until the end of the world. $\mathrm{He}$ contrasts the situation of human knowledge with the indisputability of death. In Chapter 28 of Eikonoklastes, he acknowledges that, "For all other human things are disputed, and will be variously thought of to the Worlds end. But this business of death is a plaine [212] case, and admitts no controversie; In that center all Opinions meet” (582). Derrida and Milton think similarly about history to the extent that everything in human life remains open to disputation and interpretation with no absoluteness or finality. Both locate this openness in language, and both emphasise that the enlargement of truth and justice occurs in history as the consequence of the work of singular human beings, who share the attributes of Milton's fit reader and Derrida's democratic intellect. The moment in which this enlargement is most possible is what Milton calls a trial and what Derrida calls an aporetic moment/space. 
Chapter Four

\section{The Critique of Violence: The "Fit Reader" Does Justice on the Lawless King}

The focus of the discussion in Chapter Three was Milton's demonstration and exemplification of the qualities and attributes of his fit reader in Eikonoklastes. I examined the relation and distinction between the concepts of law and justice in Milton and Derrida. Both thinkers understand law as deconstructible, while justice is undeconstructible for them. The problematic interval between law and justice creates an aporetic moment/space the experience of which is central for the fit reader to make a just decision. In such a moment of aporia, laws, principles, and norms of society get exposed to radical questioning and critique. The law/voice of "good conscience and reason" is the fit reader's only authority for making a just decision.

In this chapter, the question of the critique of violence is the core issue. Derrida, in the second part of "Force of Law," argues that elimination of violence within laws is impossible. There is always, he asserts, violence in the very founding moment of law. Law is never established in a complete form and it always requires the monopoly of violence to preserve itself. Derrida calls this the paradox of iterability, which is the indispensibility of repetition and alternation of origin. In a revolutionary moment/space, the reality of this paradoxically problematic relationship between law and violence becomes conspicuously detectable. This aporetic moment, a time during which 
established law is radically critiqued and suspended by the violence of some new law, is fundamentally threatening and deconstructive. The true critique of violence, Derrida argues, is only possible within such a moment/space of aporia that falls outside of systems and structures. True critique is impossible unless it is accomplished outside of the frames of critique and critical activities defined and authorized by the state.

In his controversial tract, The Tenure of Kings and Magistrates, which was published a short time after the execution of King Charles I, Milton argues that putting the King on trial was the absolute right of the people and his execution the very practice of the "sword of justice." He argues for their absolute right to question, and depose if necessary, their kings and magistrates if they act tyrannically against the good of their people. In other words, he emphasises the indispensibility of the radical critique of rulers (arbitrary tyrants) that misuse their power and the force of law by turning it into violence against their people. To demonstrate this absolute necessity, he accounts for the potential of authorities to turn into tyrants. This possibility of violence is inherent within any system because of the desire of rulers to monopolize the force of law for their private aims and interests. In addition, the power of kings and magistrates, he argues, has been never original and absolute. People can reclaim the power given to their authorities whenever necessary. Kings and magistrates have to prove themselves constantly to their people, otherwise the contract between them will be automatically revoked and the relation between the king and his subjects will enter a revolutionary moment/space. This is the time of crisis within which the law or the system of government is fundamentally suspended and questioned. In this moment, the true nature 
of law and violence becomes conspicuously transparent and the true critique of violence becomes possible. I will be arguing that Milton's main intention in the two editions of The Tenure is to delineate revolutionary moment/space of suspense and the necessity of experiencing such a moment/space for the fit reader, issues which are consistently present throughout his writings and specifically of central importance in the two versions of The Tenure. Each version has to be examined as a singular production and in relation to the principle that all decisions and judgments are context-specific. There is a strong consistency in Milton's thought about justice, truth, humanity, and democracy in the sense of the to-come; however, differences and adjustments do exist depending on various contexts and circumstances.

\section{The Homogeneity of Law and Violence}

In the second part of "Force of Law," Derrida asserts that the notion of Gewalt (a German term used by Walter Benjamin in his article "Critique of Violence") is "so difficult to translate ('violence,' but also 'legitimate force,' authorized violence, legal power, as when one speaks of Staatsgewalt, state power) [...]" (262, his emphasis). He continues that "Gewalt can also mean the dominance or the sovereignty of legal power, the authorizing or authorized authority: the force of law [loi]" (264-65). It denotes straight away an illegal act of power and even the exercise of massacres and cruelties. But, as Derrida emphasises, this term in the German language refers also to legal force and the work of enforcing the order of law in society. What is significant here is that the term identifies the complexity in the operation of power in society. 
Derrida indicates that, at its most fundamental level, law has an interest in excluding any violence that threatens its order and "thus to monopolize violence, in the sense of Gewalt, which is also to say authority" (267). In Derrida's thought, law as such has an interest in a monopoly of violence and "This monopoly does not strive to protect any given just and legal ends (Rechtszwecke) but law itself" (267). Discussing the right to strike as a good example with which to think through the implications of having a monopoly over power, he argues that law and violence are homogeneous. Derrida argues that only those who are part of the state are "guaranteed a right to violence (Recht auf Gewalt) and so to share the monopoly of the state in this respect" (267). Workers possess the right to strike, but Derrida argues that

$[\ldots]$ if the strike persists, we have a revolutionary situation. Such a situation is in fact the only one that allows us to conceive the homogeneity of law and violence, violence as the exercise of law and law as the exercise of violence. Violence is not exterior to the order of law. It threatens law from within law. Violence does not consist essentially in exerting its power or a brutal force to obtain this or that result but in threatening or destroying an order of given law and precisely, in this case, the order of state law that was to accord this right to violence, for example the right to strike. (268, his emphasis)

For Derrida, the notion of violence refers to the force of law without which there would be no law. When a law is introduced, agreed upon, proclaimed, or announced it must be 
enforceable as well. The fact of violence in the foundation of law is demonstrated not only by physical enforcement, but also by symbolic means, in the power supporting the proclamation or the declaration of the law and the performative acts by which it is interpreted and applied. Law and violence are homogeneous because violence is necessarily implicit in the very moment of proclaiming and establishing a law.

\section{The Paradox of Iterability and the Foundation of the Law}

There is always the possibility of a kind of violence that threatens governments and the structures of power. This violence is not the usual disobedience to law but a revolutionary violence that attacks the very foundations of law and state powers. In a revolution, a new founding violence asserts itself and, if its challenge to the state is successful, enforces the establishment of a new law, a new legal system, and perhaps a new state or government because the legitimacy of the state is bound up with the enforceability of its laws. The new founding violence, Derrida argues, is "able to justify, to legitimate (begrunden), or transform the relations of law (Rechtsverhiiltnisse) and so to present itself as having a right to right and to law" (268, his emphasis). Derrida indicates that it is only at this very moment, when the law is fundamentally threatened

and suspended, that the critique of violence is possible. The new violence belongs to a law that remains to be established; this law will exist in the future, and it is the law on the basis of which the new founding violence will be retrospectively justified and therefore legitimated. 
For Derrida, the critique of violence has to be "an interpretative and meaningful evaluation of it," and to make a true critique possible "one must first recognize meaning in a violence that is not an accident arriving from outside the law" (268-69). That which threatens law comes from the law itself and belongs to it, to the right to law, to the origin of law. He argues that all revolutionary situations and discourses on the left or on the right similarly attempt the justification of their violence by referring to the establishment of a new law and a new state. The law to come legitimates, retrospectively, the violence that is responsible for its establishment. Such revolutionary moments are always "mystical" and terrifying not only because of all the suffering and crimes which happen in these violent moments, but also:

[...] because they are in themselves, and in their very violence, uninterpretable or undecipherable [...] This moment of suspense, this epokhe, this founding or revolutionary moment of law is, in law, an instance of nonlaw [dans Ie droit une instance de nondroit]. But it is also the whole history of law. This moment always takes place and never takes place in a presence. It is the moment in which the foundation of law remains suspended in the void or over the abyss, suspended by a pure performative act that would not have to answer to or before anyone. (269-70, his emphasis)

Further consideration of this aporetic moment/space leads Derrida to argue that it is impossible to maintain a distinction between the violence (war, for example) occurring 
in the founding of a state and the violence employed by the state to preserve its existence. It is only when you take a position and argue from the perspectives of a particular system or structure that you can consider one as legitimate force and another as violence:

On the one hand, it appears easier to criticize the violence that founds since it cannot be justified by any preexisting legality and so appears savage. But on the other hand, and this reversal makes the whole worth of this reflection, it is more difficult, more illegitimate to criticize this same founding violence since one cannot summon it to appear before the institution of any preexisting law: it does not recognize existing law in the moment that it founds another. (274, his emphasis)

This unresolvable contradiction is the question of the revolutionary moment in which a new law threatens the established law and enforces its own establishment. Derrida argues that this moment is part of "no historical, temporal continuum" in which "a new law nevertheless plays [joue], if one can say so, on something from an anterior law that it extends, radicalizes, deforms, metaphorizes or metonymizes" (274). Such a moment will take the form of a war or a general strike. Derrida asserts that this is a contamination that "effaces or blurs the distinction, pure and simple, between foundation and preservation. It inscribes iterability in originarity, and this is what I would call deconstruction at work, in full negotiation: in the 'things' themselves and in Benjamin's text" (274-75). 
The work of deconstruction is at work in all structures and systems within which the law and violence must coexist because of what Derrida terms the "differential contamination" of the revolutionary claim to institute a new origin by what precedes it and is repeated. Derrida argues that iterability "makes it so that the origin must [doit] repeat itself originarily, must alter itself to count as origin, that is to say, to preserve itself [...] Rigorously speaking, iterability precludes the possibility of pure and great founders, initiators, lawmakers" (277-78, his emphasis). The crucial point here is that the foundation of a new law is not just a historically completed event, but also an event that contains a future dimension:

A foundation is a promise. Every positing (Setzung) permits and promises, posits ahead [permet et pro-met]; it posits by setting and by promising [en mettant et en promettant]. And even if a promise is not kept in fact, iterability inscribes the promise as guard in the most irruptive instant of foundation. Thus it inscribes the possibility of repetition at the heart of the originary. Better, or worse, it is inscribed in this law [1oi] of iterability; it stands under its law or before its law [sous sa loi ou devant sa loi]. (272, his emphasis)

There is no pure foundation of law and no pure founding violence. To found a law is a call for preserving it as well. Therefore, with founding violence, there is a purely preserving violence. To preserve the law is in fact the refounding of the law. Derrida 
argues that "there can be no rigorous opposition between positing and preserving, only what I will call (and Benjamin does not name it) a differential contamination between the two, with all the paradoxes that this may lead to" (272, his emphasis). Deconstruction is made possible by the necessity of this differential contamination, this paradox of iterability, this aporetic moment in which foundation and preservation of law take the form of a promise in future and the to-come.

\section{The Aporetic Moment of Suspense}

In "Force of Law," what particularly interests Derrida about Benjamin's essay "Critique of Violence" is that it reflects "the crisis in the European model of bourgeois, liberal, parliamentary democracy, and so the crisis in the concept of law that is inseparable from it" (263). The originality of this crisis, according to Derrida, comes from certain modern features, like "the right to strike," "the concept of general strike," the time of "the aftermath of a war and a prewar era," the question of the right to punish and capital punishment, and "Change in the structures of public opinion, thanks to the appearance of new media powers such as radio" (263). Derrida argues that the last feature "begins to put into question this liberal model of parliamentary discussion or deliberation in the production of laws [lois] and so forth" (263, emphasis added). The crisis more than anything has to do with the relation between law/authority/government/state and violence/force/power in a democratic polity, and specifically, confrontations and conflicts among these concepts on the symbolic level. A new foundation for a state is 
achieved by two interrelated processes, critique of the fundamental conceptual/legal structures of the state (symbolic violence) and physical conflict (actual violence). The former occurs in the mental realm/space and the latter in society and history.

The significant point here is identified in the phrase, "begins to put into question," and whether this beginning is an opening to an aporetic situation/moment. No doubt all critique, even from the most conservative and the least radical reformist movements, claims to question a current status quo, but without intending to open the possibility for a revolutionary, devastating situation to occur. This "beginning to question" leads to an aporetic, revolutionary situation only if the question turns out to be so fundamental that the existing power structure does not permit its resolution through discussion. This does demonstrate the fundamental significance of the events on the symbolic level, referred to as performative acts. The performativity of pre-revolutionary debates and discussions may bring a certain state of affairs to an aporetic, problematic moment/space that might lead to fundamental changes and the start of a process on the symbolic level that finally leads to foundational violence. To "begin to put into question" on the symbolic level is the inaugural moment of a potential change and the opening of an aporetic space in which all current laws and norms can be suspended and fundamentally critiqued. Derrida argues:

To be schematic, there are two violences, two competing Gewalten: on one side, decision (just, historical, political, and so on), justice beyond law and 
the state, but without decidable knowledge; on the other, decidable knowledge and certainty in a realm that structurally remains that of the undecidable, of the mythic law and of the state. On one side is the decision without decidable certainty, on the other the certainty of the undecidable but without decision. In any case, in one form or another, the undecidable is on each side, and is the violent condition of knowledge or action, but knowledge and action are always dissociated. (291, his emphasis)

In the aporetic moment/space, the questions are so fundamentally critical that, if a decision becomes necessary, it is made without decidable knowledge and certainty, and it is made as a result of the radical suspending and questioning of established laws. If not so, there will be only non-decision or calculation with the certainty of established laws and systems. Power structures do not fear criminal actions and organizations such as illegal drug trafficking or the mafia, but they do fear this interpretive violence which challenges the order of the existing law and the legitimacy of the state. The symbolic violence is justified by the law to come, the law this violence attempts to establish. Derrida writes:

All revolutionary situations, all revolutionary discourses $[\ldots]$ justify the recourse to violence by alleging the founding, in progress or to come, of a new law. As this law to come will in return legitimate, retrospectively, the violence that may offend the sense of justice, its future anterior already justifies it. The foundation of all states occurs in a situation that we can thus 
call revolutionary. It inaugurates a new law, it always does so in violence.

The establishment of all regimes and systems depends on the exercise of the violence of the aporetic moment of suspense. Without this moment and its violence there would be no new law or system. Although we cannot see, touch, or catch up to the law because it is still to come, we must try to envisage it in the violence: to think of a law within violence.

\section{True Critique of Violence}

For Derrida, a successful revolution or "the successful foundation of a state" will produce interpretive models to give "legitimacy to the violence that has produced, among others, the interpretative model in question, that is, the discourse of its selflegitimation" (270). He states that this continuous process of interpretation and legitimation is a circle "in the course of which states and nations are founded, destroyed, or redesigned" (270). When logic is the logic of an established law and its symbolic order, there is no reason to expect that the radical critique of its violence can be recognized and allowed within its frame of logic or even in its symbolic order. Derrida argues that critique is:

[...] a juridicosymbolic violence, a performative violence at the very heart of interpretative reading. [...] One has the right to suspend the legitimating 
authority and all its norms of reading, and to do this in the most incisive [Ies plus lisantes], most effective, most pertinent readings, which of course will sometimes argue $\left[s^{\prime}\right.$ expliquent $]$ with the unreadable in order to found another order of reading, another state, sometimes without doing it or in order not to do it. [...]

In sum, the two temptations of deconstruction. (271)

The work of critique, when a reading founds something new and this new thing is unreadable in the established norms and frames of reading available to the society, opens the possibility of a revolutionary situation both metaphorically and actually. Derrida's deliberation about the nature of this work is of fundamental importance for the link he makes between deconstructive analysis and law/violence/justice:

In the title "Critique of Violence," critique does not simply mean negative evaluation, legitimate rejection or condemnation of violence, but judgment, evaluation, examination that provides itself with the means to judge violence. The concept of critique, insofar as it implies decision in the form of judgment and question with regard to the right to judge, thus has an essential relation, in itself, to the sphere of law. [...] The concept of violence (Gewalt) permits an evaluative critique only in the sphere of law and justice (Recht, Gerechtigkeit) or the sphere of moral relations (sittliche Verhaltnisse). [...] The concept of violence belongs to the symbolic order of law, politics and morals - of all forms of authority and of authorization, of 
claim to authority, at least. And it is only to this extent that it can give rise to a critique. Up to this point this critique was always inscribed in the space of the distinction between means and end. (265)

Thus, the concept of critique has an essential relation to the question of law. In addition, the concept of violence has relations (in fact belongs to) to the symbolic order of law, politics, morals, and all forms of authority. Derrida argues that the critique of violence is not possible when it is considered within the relation between means and ends. The two traditions which account for violence in terms of this relation are the tradition of natural law and the tradition of positive law. Derrida indicates that both traditions "share the same dogmatic presupposition, namely, that just ends can be attained by just means. $[\ldots]$ there is no solution for the antinomy when a contradiction emerges between just ends and justified means" (266). Deconstructive critique shifts the attention to the symbolic order in a process of evaluative judgment, which has decision-making and justice as its goal. The true critique of violence is only possible when one fundamentally questions it outside of the laws and logic of any established system or structure in society. To question violence in the frame of a specific system and on the basis of the established laws of that system, for Derrida, is not true critique at all.

\section{Potential Tyranny and the Temporariness of Foundation}

In The Tenure of Kings and Magistrates, Milton analyses the relation between law and violence from the perspective of justice and individual freedom. He surveys historically 
the foundation of governments and legal-political systems in the form of an original agreement, contract, or law. The original announcement, proclamation, or declaration of all states and governmental structures is what Derrida refers to as the performative act of founding a law as violence. For Milton, this performative force is considered as violence as well but in a different way. It is violent since it is a violation of human nature and God's law. God has created man free and no one has the right to rule the other. The very foundation of the first law, the very original law was in the form of an agreement or contract which goes against the law of nature; that is, people agree to submit themselves to some representatives who are their own equals. In this sense, in Milton's framework of thought, violence is integral to the foundation of law. Legalpolitical systems are full of potential destructiveness and violence; they are always on the verge of falling into tyranny, ${ }^{43}$ which is against the very nature of mankind and God's creation:

It follows lastly, that since the King or Magistrate holds his authority of the people, both originally and naturally for their good in the first place, and not his own, then may the people as oft as they shall judge it for the best, either choose him or reject him, retain him or depose him though no tyrant, merely by the liberty and right of free born men, to be governed as seems to them best. This, though it cannot but stand with plain reason, shall be made good also by Scripture. (Deut. 17.14): When thou art come into the Land which

\footnotetext{
${ }^{43}$ For a discussion on the question of violence and evil in Paradise Lost, see Robert Appelbaum's essay, "Milton, the Gunpowder Plot, and the Mythography of Terror (Garry Wills)," in which he argues that "Paradise Lost preserves the ideas that violence and terror are systematic" (490).
} 
the Lord thy God giveth thee, and shalt say I will set a King over mee, like as all the Nations about mee. These words confirm us that the right of choosing, yea of changing their own government is by the grant of God himself in the People. (1031-32)

In The Tenure, Milton focuses from the outset of his argument on the foundation of kings and states, and the way they have been given power and supremacy over "their brethren." Accordingly, in order to "prove, that turning to tyranny they [kings or magistrates] may be as lawfully deposed and punished, as they were at first elected" (1028). ${ }^{44}$ Milton examines the question of law and the state, their foundation, and their legitimacy. In Milton's argument, the primary structures of law and the state are first established by "agreement" among equals, made necessary by the consequences of the Fall:

Till from the root of Adams transgression, falling among themselves to do wrong and violence, and foreseeing that such courses must needs tend to the destruction of them all, they agreed by common league to bind each other from mutual injury, and jointly to defend themselves against any that gave disturbance or opposition to such agreement. Hence came cities, towns and commonwealths. (1028)

\footnotetext{
${ }^{44}$ See Matthew Neufeld's essay, "Doing without Precedent: Applied Typology and the Execution of Charles I in Milton's 'Tenure of Kings and Magistrates' (John Milton)." In this essay, he examines "Milton's use of biblical, classical, and national historical types of the regicide to exhort his readers to view the king as a tyrant, his death as a biblically and historically warranted punishment."
} 
However, because "no faith in all was found sufficiently binding," they came to the conclusion that they needed "to ordain some authority, that might restrain by force and punishment what was violated against peace and common right" (1028, emphasis added). For Milton, this is the only reason why free persons have accepted some authority and jurisdiction over themselves. Throughout his essay, he enforces the idea that authorities/states/kings in their relations to their subjects have no special privilege over them because they are granted authority by their people. The people must constantly remain vigilant concerning the possibility of violence (tyranny) implicit and inherent in the law that has established the authority of the state. He argues that kings or magistrates have never been able to demonstrate that their authority originated from God: 45

And it were worth the knowing, since Kings in these days, and that by Scripture, boast the justness of their title, by holding it immediately of God, yet cannot show the time when God ever set on the throne them or their forefathers, but only when the people chose them, why by the same reason, since God ascribes as oft to himself the casting down of Princes from the throne, it should not be thought as lawful, and as much from God, when none are seen to do it but the people, and that for just causes. For if it needs

\footnotetext{
${ }^{45}$ For a detailed discussion on Milton's rejection of the idea of king as divinely appointed and the relationship between father, king, and God, see John G. Peters' essay, "Father, King, and God: John Milton's Prose Response to Monarchy."
} 
must be a sin in them to depose, it may as likely be a sin to have elected. (1033-34)

In order to prevent the dangers of the arbitrary use of power, the people invented laws "either framed, or consented to by all that should confine and limit the authority of whom they chose to govern them" (1029). Inventing the law, humans hoped to replace the rule of man with the rule of law and reason and consequently avoid the potential for errors, dangers, and violence in governments. Milton argues that kings and magistrates are positioned above the people but law is above them all. Taking oaths is the last solution to prevent the practice of tyranny and violence with the exercise of justice. The oath is the king's constant promise to their people as long as they hold authority and power.

When this would not serve, but that the Law was either not executed, or misapplied, they were constrained from that time, the only remedy left them, to put conditions and take Oaths from all Kings and Magistrates at their first installment to do impartial justice by Law: who upon those terms and no other, received allegiance from the people, that is to say, bond or covenant to obey them in execution of those Laws which they the people had themselves made, or assented to. And this ofttimes with express warning, that if the king or magistrate proved unfaithful to his trust, the people would be disengaged. (1029) 
Threat, uncertainty, and potential violence within the state (any established law or ruling structure) prove to be inescapable parts of all states and laws. For Milton, no states or established governments are exempt from this internal threat or violence. Arbitrary power is pregnant of evil and violence. Laws, taking oaths, parliament and counsellors are the measures taken to prevent kings and states from monopolizing violence. Milton emphasizes that the constant principle of public supervision of the exercise of authority contains the inherent possibility of the people's violence against the violence of the state, if necessary. The practice of this principle begins in the critique of the state and the law, which can express itself as an interpretative, performative act of violence.

\section{Time of Crisis: "no man is further bound to Law"}

Milton demonstrates in The Tenure that states and governments throughout history have tried unsuccessfully to establish an absolute law and state on earth, and he insists that there is no absolute, ahistorical origin for Charles' kingdom or any other government. For him, the origin of Charles' monarchy, like that of all other states, is in human law and (dis)order. He argues:

Therefore Kingdom and Magistracy, whether supreme or subordinat, is without difference, call'd a human ordinance, I Pet. 2.13. \&c. which we are there taught is the will of God wee should alike submitt to, so farr as for the punishment of evil doers, and the encouragement of them that doe well. Submitt saith he, as free men. But to any civil power unaccountable, 
unquestionable, and not to be resisted, no not in wickedness, and violent actions, how can we submitt as free men? (1033)

In Milton's thought, kings and rulers "have no privilege to be exempted from the punishments of Law more than any other subject; so that if the King be a Murderer, Adulterer, or Idolater, he should suffer, not as a King, but as an offender [...]" (1040). He argues that the foundation of all kingdoms and states lies in social-political bonds. If a king violates the principles of the contract, the subjects are no longer bound to law and the Kingdom. In such a problematically revolutionary moment, the law is suspended and another supreme authority and law will found itself, a moment/space of suspense in which a new law will stand against the former established law of the state. Milton asserts:

Out of doubt then when the King shall command things already constituted in Church, or State, obedience is the true essence of a subject, either to doe, if it be lawful, or if he hold the thing unlawful, to submit to that penalty which the Law imposes, so long as he intends to remain a Subject. Therefore when the people or any part of them shall rise against the King and his authority executing the Law in anything established civil or Ecclesiastical, I do not say it is rebellion, if the thing commanded though established be unlawful, and that they sought first all due means of redress (and no man is further bound to Law) but I say it is an absolute renouncing both of Supremacy and Allegiance, which in one word is an actual and total 
deposing of the King, and the setting up of another supreme authority over them. (1042)

What Milton is exploring here is identical to Derrida's "aporetic moment of suspense," a radical moment when the established law is fundamentally threatened by a new founding violence and law. Milton argues that the uprising of people against their king and the established law is not unlawful or a rebellion in such a moment. ${ }^{46}$ In such a revolutionary moment/space, distinguishing lawful from unlawful and just from unjust becomes radically impossible. Subjects are no longer "bound to Law" and their king. To Milton, the element of radical critique is the most important element of this problematic situation which must be always practiced as a balancing and controlling force. In such a moment, the people are not further bound to the law and the whole system and law are fundamentally questioned and critiqued. If this radical moment stays, the people have the right to depose the king, suspend the established law and found (or set up, as Milton says) a new law and government. Like Derrida, Milton elaborates the revolutionary moment/space of aporia here.

The crucial reality related to the King's trial was that no one was able to anticipate how the process of the trial would end. ${ }^{47}$ Most judges tried to avoid execution, but finally the

\footnotetext{
${ }^{46}$ See David Loewenstein's essay, "An Ambiguous Monster, Representing Rebellion in Milton Polemics and 'Paradise Lost,"' in which he argues: "But for Milton monstrous rebellion could also be equivocal and many-headed in the sense that it readily assumed many forms and operated in language and through artifice" (296).

${ }^{47}$ For a detailed discussion on the very condition of the trial of Charles I and the unpredictable, adventitious, and even accidental nature of the trial's outcome, see Sean Kelsey's essay "The Trial of
} 
challenge to the authority of the Parliament (the High Court represented the Parliament) could not be evaded. This was a moment in which prediction or continuity (cause and effect sequences) in action or process was suspended. We experience this state of affairs in textual/critical practice, which reveals the supplement or trace in every concept, or in the singular action of doing justice, which exceeds the calculation of the rule. This is the time of crisis, the time of the aporetic moment/space of suspense. The execution of Charles I is the most immediate outcome of the trial; it was not either the predicted or desired outcome but defined the new path which England took as a result of the application of (the sword of) justice in the moment of aporia or the trial of the King. Execution in the context of a contest of authorities, powers and laws was certainly a violent act, and the trial situation could well be described as "the time that the just and unjust are unidentifiable" because the agreement by which such determinations can be made and carried out has been suspended. This moment offered the possibility of the occurrence of something other than the known or calculable; a normal, legal trajectory is broken and when it is re-founded, nothing is the same again.

\section{The Right to Depose Kings/Magistrates}

In the first paragraph of The Tenure, Milton examines the qualities and attributes of two groups of people considering their ability to discern tyranny and demonstrate a free and virtuous critique of violence. In order to make a true critique of social-political powers,

Charles I" in which he argues that "one final attempt was made in January 1649 to force a peaceful settlement on the King, that his trial was no simple prelude to regicide, and that his execution was in fact the unlooked-for outcome of a proceeding undertaken to quite opposite ends" (585). 
one must be able to stand mentally outside of all external and internal laws, regulations, and restrictions. One name Milton uses for people with this ability is "good men"; by contrast, "bad men" compromise with the state or the law, and are consequently unable to practice a radical critique. ${ }^{48} \mathrm{I}$ am using "fit reader" as a broader term for this group of good men or the "fit audience." A fundamental requirement for being a fit reader/audience is the ability to interpret texts of all kinds. Milton states:

If men within themselves would be governed by reason, and not generally give up their understanding to a double tyranny of custom from without, and blind affections within, they would discern better, what it is to favor and uphold the Tyrant of a Nation. But being slaves within doors, no wonder that they strive so much to have the public State conformably governed to the inward vicious rule, by which they govern themselves. For indeed none can love freedom heartily, but good men; the rest love not freedom, but license; which never hath more scope or more indulgence then under tyrants. Hence is it that tyrants are not oft offended, nor stand much in doubt of bad men, as being all naturally servile; but in whom virtue and true worth most is eminent, them they fear in earnest, as by right their masters, against them lies all their hatred and suspicion. Consequently neither do bad men hate

\footnotetext{
${ }^{48}$ Matthew Neufeld in his essay, "Doing without Precedent," argues that by "writing and publishing The Tenure during the most controversial period in English history, Milton was imagining through his prose a particularly politically engaged readership." He says Milton invited his readers "to embrace a radical yet rational mode of thought for traumatic political events."
} 
tyrants, but have been always readiest with the falsified names of loyalty, and obedience, to color over their base compliances. (1025, his emphasis)

The alternative authority for a good man/fit reader is his reason/conscience. Such people are always under suspicion by states and governments because they potentially threaten the established order. Because of their love of freedom, they are critically aware of the law's limitations and incompleteness. It is in connection to the questions, "What a tyrant is" or "who in particular is a Tyrant?", that Milton provides us with a definition: "A Tyrant whether by wrong or by right coming to the Crown, ${ }^{49}$ is he who regarding neither Law nor the common good, reigns only for himself and his faction" (1034). He discusses the notion of "what the people can do" against a tyrant. The crucial moment is when the law or the state is questioned, judged upon, suspended, and may be abolished.

Milton also refers to the "true Church" (an institution that must work for truth and justice without any attachment to the economic and political powers of the time) and the "Saints of God" (good men who act for justice and against any violence by established authorities) as the enemies of tyranny and unjust, violent states. For Milton, the interpretative and performative force is what most frightens states and power structures, the force which is experienced not in crime or breach of the laws in the usual sense, but in the performative act of fundamental questioning that threatens the foundation of law

\footnotetext{
${ }^{49}$ Milton denies the difference between the two categories of tyrant: tyrants by practice (those leaders and kings that are primarily legitimate but descend into tyranny) and tyrants by usurpation (someone who comes to power in illegitimate ways).
} 
and authority and targets their very legitimacy. Milton summarizes the characteristic tendency of this force as "the dissolution of all tyranny:"

Surely it is not for nothing that tyrants by a kind of natural instinct both hate and fear none more than the true Church and Saints of God, as the most dangerous enemies and subverters of Monarchy, though indeed of tyranny; hath not this been the perpetual cry of Courtiers, and Court Prelates? whereof no likelier cause can be alleged, but that they well discerned the mind and principles of most devout and zealous men, and indeed the very discipline of Church, tending to the dissolution of all tyranny. (1037)

Milton here exemplifies the true critique of violence by referring to the fear and hate of tyrants towards "the true Church and Saints of God." They are the serious enemies of tyrannies, not outlaws or criminals; they fundamentally threaten the foundation of law and the state. Their radically critique of unjust power structures can result in the dissolution of tyrannical states. For Milton, only this is the true critique of violence.

\section{The "Fit Reader" Does Justice on the Lawless King}

The fundamental and controversial question Milton presents in The Tenure is who has the right to lawfully resist a tyrant or wicked authority. In his introduction to The Tenure, John Rumrich asserts that politically, "Tenure is Milton's most radical work" (The Complete Poetry 1021). The full title of the first edition of The Tenure 
unambiguously clarifies Milton's main purpose: proving that it is lawful, and hath been held so through all ages, for any, who have the power, to call to account a tyrant or wicked king, and after due conviction, to depose and put him to death if the ordinary magistrate have neglected or denied to it (The Complete Poetry 1021, his emphasis) In the second edition, he adds the statement that "to do justice on a lawless king is to a private man unlawful, to an inferior magistrate lawful" (The Complete Poetry 1054). This significant shift in his position has become a focus of discussion in Milton criticism. ${ }^{50}$ The search for any probable reason to describe this apparent change of position has resulted in close consideration of the historical context in which Milton wrote the two different versions of his tract. For instance, John Rumrich argues that Milton in the second edition of The Tenure retreats from his first position because the political situation has changed greatly. He argues:

A new government of dubious legitimacy and with many opponents was in place. It needed to shore up its support or at least undermine its opposition. [...] Perhaps after due consideration Milton wanted to back away from a position that he himself has come to see as too extreme. More likely he wanted to remind the Presbyterians to restrain their own opposition by citing the opinion of the authorities they most honored. (1023)

\footnotetext{
${ }^{50}$ See Martin Dzelzainis' "Introduction" to John Milton in which he argues that overall one is not altogether clear who can lawfully resist a tyrant.
} 
More recently, Go Togashi, in his article "Milton and the Presbyterian Opposition," has argued that critics have not paid enough attention to The Tenure in relation to the controversial arguments dominating the period between 1649 and 1650 . He asserts that Milton's different positions, adopted in the first and the second editions of The Tenure, are due to the confusion and uncertainty of the period. In other words, the different position taken in the second edition must be viewed in the light of "the predicament the infant republic found itself in" (59) after the execution of the King. He argues that a difficult period of contradictory arguments put Milton in a predicament or irreconcilable situation, which demonstrates how difficult it was for him to choose. Therefore, the seeming "volte face" in the second edition, Togashi argues, "is not a volte-face quick and easy, but an irreconcilable conflict between two contending positions, the one Milton espoused and the one he had learned to espouse. After much wavering between them, he could barely make a choice" (74).

My contention in terms of the question of Milton's different positions in the two versions of The Tenure is that we must think of each version as a singular production and avoid interpretations that reject one of Milton's positions in favour of the other. In other words, Milton's general intention in his works is to demonstrate the indispensibility of experiencing the aporetic moment/space of decision for justice, and this is true of the two versions of The Tenure. The difference between the two versions relates to the specifics of their singular contexts. All decisions and judgments are 
context-specific.$^{51}$ There is a strong consistency in Milton's position about justice, truth, humanity, and democracy in the sense of the to-come; however, differences and adjustments do exist in his different works depending on various contexts and circumstances. At a particular time and place, there are always differentiations in the way in which a particular position is taken and expressed. My argument here in a new way supports John Rumrich's position and makes it more explicit. What Togashi and others miss about Milton's argument in the first and the second edition of The Tenure is his emphasis on the revolutionary moment/space of suspense and necessity of experiencing such a moment for the fit reader. The consideration of Milton's model of radical, critical reading, and the moment of decision makes it possible to account for the differences between his works and even different versions of the same work without explaining the differences away.

Milton's first position is declared in company with essential conditions: "proving that it is lawful, and hath been held so through all ages, for any, who have the power, to call to account a tyrant or wicked king, and after due conviction, to depose and put him to death if the ordinary magistrate have neglected or denied to it" (The Complete Poetry 1021, his emphasis). The crucial question is the relation between these conditions and Milton's second position. My argument is that in the second edition of The Tenure Milton still completely believes in these conditions and preserves them, unaltered. In fact, I propose that the attributes, qualities, and conditions Milton ascribes to his fit reader are kept comprehensively unchanged. We read here that one is to act only when

\footnotetext{
${ }^{51}$ See Stanley Fish's essay, "To the Pure All Things Are Pure."
} 
he reaches a "due conviction" which I understand as the individual's achieving certainty due to fully undertaking a singular process of radical critique within a specific moment/space of aporia. The other condition applies when ordinary magistrates (potential fit readers) do not fulfil their duty and responsibility. Milton's fit reader can be anyone from an ordinary person to public individuals and authorities. For him the imperative question is that "all men naturally were born free" and must attempt to become fit readers in their own societies. To do justice on wicked authorities can be pursued by other individuals of a society when inferior magistrates and officials, for any reason, fail to perform their responsibilities. Milton in The Tenure declares that the power of kings and magistrates is always derivative, unoriginal, and mediated. Magistrates and ordinary people have this right to reclaim this power, but Milton here does not support acts of anarchism or barbarian lawlessness. The point is who is able to identify and judge a tyrant or wicked ruler? Who can become a fit reader and judge a king? Milton's answer is anyone can be a fit reader if they develop the essential attributes and qualities.

The crucial question, furthermore, is the critique of violence, true understanding of which depends on the experience of a revolutionary moment in which the law as such is suspended. It is the moment of changing, abolishing, and founding law through the radical critique of violence. Milton explores the revolutionary moment/space of his time, the time of civil war and regicide, a time when the legitimacy of law is suspended and an extremely confusing, radically insoluble situation prevails. In an aporetic moment/space, concepts and terms disintegrate in terms of an established structure of 
values and lose their accepted meanings. In the period immediately before and after the execution of the King, the law is fundamentally suspended, questioned, and changed. For Milton, this is the time when the contract between the King and his subjects is revisited and reviewed, the time when the subjects have the right to reclaim the power granted to the King. For Milton, anyone who has the power and attributes - and better if it is someone with a public office - is responsible for determining that the King is a tyrant and deposing him if necessary. At this very aporetic moment of decision, subjects are no longer liable to the law, contract, or agreement between them and their ruler because of his unjust conduct and actions against his people. In his argument, Togashi does not take into account this aporetic moment as a component of Milton's thought in The Tenure. Milton firmly repeats his statements in his second edition of The Tenure. His additional passages to the second version and most important of all the statement "to do justice on a lawless king is to a private man unlawful, to an inferior magistrate lawful" (1054) should be read in the context of their composition. This statement does not diminish the credibility of Milton's statements in the first edition if we consider the aporetic moment of decision as Milton's primary insistence and concern.

Milton's different positions in the two versions of The Tenure are an outstanding example of the way an author (with the qualities of a fit reader) can disagree with himself/herself and present different perspectives and judgements about the same questions and ideas in different contexts and situations. As Peter Herman argues in Destabilizing Milton, the conventional forms of criticism generate demands to find a way to make the author concur with himself/herself throughout his works. The 
indeterminacies and uncertainties of each aporetic moment/space of decision for a fit reader - a writer is also a reader - could always create differences and disagreements in comparison to a previously articulated position. Milton's position in the second version of The Tenure is different from his first one because the context and the situation in which he writes the second version is different and singular.

\section{The Absolute Responsibility of the Fit Reader/Democratic Intellect}

Human societies and structures cannot survive without the force of laws, regulations, and principles. Laws are enacted and enforced by states to create and maintain order, discipline, and security in the society and for the good of their people. No one has any problem with the force of law and the authority of states as long as they are used against the spread of crime and violence. The problem occurs when the force of law is used against the citizens of a society and is justified and authorised on the same grounds of keeping order and security in the society. To distinguish and identify the concepts of force and violence will become fundamentally difficult for the groups, parties and individuals of a society at this time of crisis. This is the time that each group justifies and authorises the use of violence for the sake of law. The question of the critique of violence becomes fundamental in this revolutionary situation.

Milton and Derrida attend to these questions in their works in similar ways. Derrida argues that there is no foundation of law without violence. A law and a system of government come into existence by the exercise of founding violence and preserve 
themselves by the constant use of violence, called preserving violence. Milton also argues that no human structure and government in history has been able to found itself in an absolute form or with divine authorization. He emphasises the unlimited potential for tyranny and the enforcement of law against its citizens by the state. The establishment of laws and governments is possible only because of a temporary agreement or contract between the rulers and their people. Whenever the force of law (violence) is used against the people and good of the people, they have the right to reclaim the legitimacy and power given to their rulers. This is the time that citizens are no longer bound to the law and the agreement. Both Milton and Derrida emphasise the indispensibility of radical critique of violence at this revolutionary moment when all laws and rules are suspended and questioned. At this radical moment, according to Milton and Derrida, the true critique of violence occurs by exposing the relation between the law and violence/the force of law. This is the aporetic moment in which radical critique presents itself as violence directed at the established law and state system for the sake of establishing a new law. For both authors, the exercise of the true critique of violence is the absolute responsibility of individuals (fit readers/democratic intellects) in a society. A fit reader/democratic intellect unfolds the fundamental violence of power structures through their radical critique and exposes them to radical re-assessment and re-interpretation to allow some openings towards a better human society, democracy, or humanity to come. 


\section{Chapter Five}

\section{The Lawless Institution of Literature}

One of the controversial issues in Milton criticism is how to determine his theory of poetry because his writings about his poetics are not integrated into one account but are made both directly in his comments on poetry scattered throughout his prose and poetry, and indirectly by his poetic works. What inherited rules did he endorse and what did he modify and invent in his own writings? There have been always critical attempts to separate Milton's prose works from his poetry; even Milton himself does this by referring to the work of his left and right hand, Milton the pamphleteer and Milton the poet. Attempts to find a consistent theory of poetry in Milton's scattered passages on the question of poetics and from the evidence of his poetic works typically discover ${ }^{52}$ indeterminacies, uncertainties, and contradictions in Milton's works and have recently produced a group of Miltonists who argue that Milton's major poetic works lack any consistent poetics. ${ }^{53}$ Nevertheless, scholars trying to account for Milton's poetics have developed vastly different conceptions and terms, like passional poetics, poetics of

\footnotetext{
${ }^{52}$ In "The Development of Milton's Poetics," Irene Samuel argues that many of Milton's statements about poetry are "chance observations, not firmly held principles." They "cannot represent the whole of Milton's poetics," she argues. Those passages on poetics "cannot be taken as fragments from a fully articulated or even a single consistent theory. In the course of his life his views on church government, monarchy, parliaments, the training of the clergy, and a variety of other matters changed markedly; so too his poetics." Nevertheless, she argues, there is still an essential continuity that "links Milton's convections about poetry, which is "the social utility of poetry' and to contribute his talents to 'the reshaping of church and state into institutions more nearly adequate to their professed ends" (232).

${ }^{53}$ See, Peter Herman's Destabilizing Milton.
} 
antitext, salvational poetics, poetics of (in)certitude, and so forth. ${ }^{54}$ The conception I will advance, which develops out of the preceding discussion of the aporetic moment, is "the poetics of the to-come." I will argue that the kind of poetry Milton appreciates and performs seeks to go beyond the limits of the calculable in form and genre, to produce singular works the precise nature of which were in detail unpredictable and unknown to himself at the moment of composition. Poetry reveals itself as something that he wishes for, something that the already developed institutional categories are unable to include or appropriate, something that remains to come and he is trying to achieve throughout his lifetime.

The attempt in this chapter is to represent the possibility of translating some of Milton's ideas and practices concerned with the question of literature into Derrida's terms on the same question. Milton uses the term poetry in a way that resonates with characteristics Derrida identifies in relation to the institution of literature. This identification drives us to think of Milton's poetics in a way that would include his controversial prose publications in the same category. Certainly, this does not mean that Milton's prose and poetic works include all that Derrida counts as literature. There are genres, modes, forms, and many other differences and possibilities that are available to Derrida's time but unavailable to Milton and his time. Nevertheless, the desire for justice and truth, the desire for a free public, democratic institution in which one can say everything, the

\footnotetext{
${ }^{54}$ See Kari McBride and J. C. Ulreich's "Answerable Styles: Biblical Poetics and Biblical Politics in the Poetry of Lanyer and Milton;" Irene Samuel's "Development of Milton's Poetics;" Michael Fixler's "Milton's Passional Poetics, or Paradigms Lost and Regained;" Peter Herman's Destabilizing Milton; and Julia Walker's "The Poetics of Antitext and the Politics of Milton's Allusions."
} 
desire for an institution that makes the radically critical readings of the social-political powers possible via performative acts of writing becomes the common ground for Milton's conception of poetry and Derrida's notion of literature.

Milton never wrote a coordinated theory of poetry ${ }^{55}$ because he did not want to delimit himself to the available poetic theories. He urges the reader of his works to read them as the performance of his poetic theory of the to-come in which future possibilities of meaning are generated by the poem and are to be imagined by reading and enacted by readers' decisions in their singular contexts in history. The characteristics of such a form of poetry and a possible poetic theory was not predetermined, predefined, and preprogrammed for readers. For Milton, the question of the poetics of his works represents itself to his readers at the very moment of radically critical and free reading when all the authority of his texts are suspended and reaffirmed in this act of reading. In this sense, his poetry is a form in which the to-come makes itself known, but only in the act of reading. His poetry comes into existence whenever a fit reader experiences the aporetic moment/space of decision-making in relation to his writings (prose and poetry). Milton's poetics always remains to come; it is the poetics of the to-come.

\footnotetext{
${ }^{55}$ For a discussion of theories of poetry in the renaissance period and how Milton attempts to differentiate his from others, see Isabel Rivers's Classical and Christian Ideas in English Renaissance Poetry: A Students' Guide.
} 


\section{Literature as Experience}

In his interview with Derek Attridge in Acts of Literature, ${ }^{56}$ Derrida presents his thoughts on the question of literature. For him, literature is an institution, but fundamentally different from other institutions. However, like other historical institutions, the eventness of the institution of literature is subject to time, place, and context. He calls literature a strange, "lawless" institution, an "institutionless" institution. Among the main questions Derrida considers in this interview, are "How do we read literary texts?" and "Is a transcendent reading of a literary text different from other discourses?" Transcendent reading is the search for the signified or meaning, and literary writings lend themselves to this reading. Derrida emphasises that "lending" means there is no compulsion to perform such a reading; however, "every text, every discourse, of whatever type - literary, philosophical and scientific, journalistic, conversational - lends itself, every time, to this reading" (44), and depending on the types of discourse this lending would be different.

Non-transcendental reading, Derrida argues, can happen to texts in general when the relations between reader, text, and the outside of the text (its socio-political aspects) "bend towards "interest for the signifier, the form, the language" (44). The emphasis on the element of relation identifies literature as an experience rather than essence. In his account of "literarity" or "literariness" of texts, Derrida asserts:

\footnotetext{
${ }^{56}$ This interview is the first chapter of Acts of Literature entitled "'This Strange Institution Called Literature': An Interview with Jacques Derrida."
} 
The literary event is perhaps more of an event (because less natural) than any other, but by the same token it becomes very "improbable," hard to verify. No internal criterion can guarantee the essential "literariness" of a text. There is no assured essence or existence of literature. If you proceed to analyze all the elements of a literary work, you will never come across literature itself, only some traits which it shares or borrows, which you can find elsewhere too, in other texts, be it a matter of the language, the meanings or the referents ("subjective" or "objective"). And even the convention which allows a community to come to an agreement about the literary status of this or that phenomenon remains precarious, unstable and always subject to revision. (73, his emphasis)

Determining that a text is literary is a social judgment which can change over time. Derrida argues:

Moreover, there is no text which is literary in itself. Literarity is not a natural essence, an intrinsic property of the text. It is the correlative of an intentional relation to the text, an intentional relation which integrates in itself, as a component or an intentional layer, the more or less implicit consciousness of rules which are conventional or institutional - social, in any case. (44, his emphasis) 
Nonetheless, this does not signify that the essence of literature or literarity is only "projective or subjective." Derrida's thought is that the "literary character of the text is inscribed on the side of the intentional object, in its noematic structure, one could say, and not only on the subjective side of the noetic act" (44). There are features in a text that might call for literary reading and recall the "convention, institution, or history of literature" (45) although Derrida emphasises that reading a text as literature depends upon how a reader experiences that text. He argues that there "is therefore a literary functioning and a literary intentionality, an experience rather than an essence of literature (natural or ahistorical). The essence of literature, if we hold to this word essence, is produced as a set of objective rules in an original history of the 'acts' of inscription and reading" (45, his emphasis).

Derrida argues that in order to read a text as literature "it is not enough to suspend the transcendent reading" (45). This necessary suspension needs to be accompanied by an interest in or attention to "the functioning of language, in all sorts of structures of inscription, suspend not reference (that's impossible) but the thetic relation to meaning or referent" (45). Suspending reference is impossible but we can and must suspend the dogmatic, naive relation to meaning or referent. Derrida argues that the irreducible literary intentionality is the moment in which some texts intend to resist transcendent reading.

A literary text is distinguished from a non-literary one in the moment of transcendent reading. In the moment of transcendent reading, we need to ask fundamental questions, 
which would create complications and foldings in our relation to the text and put in place changes in the thetic relation to meaning and referent. Derrida does not allocate such a possibility to literary texts only, but in "preliterary poetry or epic (in the Odyssey as much as in Ulysses), this reference and this irreducible intentionality can also suspend 'thetic' and naive belief in meaning or referent" (45). To him, there are types of texts, or moments in a text, that demonstrate resistance against transcendent reading more than others do.

Derrida argues that "poetry and literature have as a common feature that they suspend the 'thetic' naivety of the transcendent reading (45)" which is not hidden in any text like an internal substance, an essence of the text. It is rather a philosophical force that remains a potentiality of the text and comes into existence only in the experience of reading which responds to that potentiality. $\mathrm{He}$ asserts that before "having a philosophical content, before being or bearing such and such a 'thesis,' literary experience, writing or reading, is a 'philosophical' experience which is neutralized or neutralizing insofar as it allows one to think the thesis; it is a nonthetic experience of the thesis, of belief, of position, of naivety" (46). This experience goes into and starts from the very moment of thesis-making in the text without taking for granted any of the accessible and established theses and positions.

In response to the question whether there would be "possibilities for re-reading everything that goes under the name of literature in ways that would counter or subvert this dominant tradition? Or would this only be possible for some literary texts" (44, his 
emphasis), Derrida indicates that one can always "inscribe in literature something which was not originally destined to be literary" and one can re-read everything as literature but "some textual events lend themselves to this better than others, their potentialities are richer and denser" (46). For him, literature has no definition because what is heralded and refused under the name of literature cannot be identified with any other discourse. It will never be "scientific, philosophical, conventional" (47), but at the same time it could open onto any of these discourses.

In his account of the difference between literature and literary criticism, Derrida argues that he does not "feel at ease either with a rigorous distinction between 'literature' and 'literary criticism' or with a confusion of the two" (52). He argues that a "good" literary criticism "implies an act, a literary signature, or counter-signature" (52). It is an "inventive experience of language, in language" (52, his emphasis); the performativity of "worthwhile" literary criticism. Literary criticism is governed by metaphysical assumptions not more than a philosophical discourse. The possibilities of rupture and fracture are structural in both. Derrida insists that "the most radically deconstructive motifs are at work 'in' what is called the Platonic, Cartesian, Kantian text. A text is never totally governed by 'metaphysical assumptions'" (53). A text is dominated by metaphysical models but there are always 'counter-forces' that threaten the authority of these models. He asserts that "These forces of 'ruin' are not negative, they participate in the productive or instituting force of the very thing they seem to be tormenting" (53). Literature is the historical, radical, and critical experience of a text that emerges through fundamentally deconstructive relations to the text. It is an event which becomes possible 
through the suspension of well-known conventional and traditional forms and forces of reading texts.

\section{Suspended Relation to Meaning}

The literarity of literature depends on the correlative of an intentional relation to the text of the writer and the reader, and its consequence, "a suspended relation to meaning and reference" (48, his emphasis). For Derrida, literature can only exceed itself because of this suspended condition. The originality of literature consists in "exhibiting, remarking, giving to be remarked this excess of language as literature" (48). Derrida argues that there is originality in this sense because literature "shows nothing without dissimulating what it shows and that it shows it" (48, his emphasis). In other words, this excessive use of language instantly betrays its originality. This is of course true about all forms of language, the very being of language in its relation with truth:

By the same token, we still have trouble defining the question of literature, dissociating it from the question of truth, from the essence of language, from essence itself. Literature "is" the place or experience of this "trouble" we also have with the essence of language, with truth and with essence, the language of essence in general. (48, his emphasis)

Literature is the place where fundamental questions are put forward in the most radical and critical way. It is because of this feature of literature that Derrida's "interest in 
literature crosses [his] interest in philosophy or metaphysics — and can finally come to rest neither with the one nor the other" (48). He asserts that some texts, which are called "literary," can question philosophy more effectively and in a sharper way than others can:

Sometimes theoretical arguments as such, even if they are in the form of critique, are less "destabilizing," or let's just say less alarming, for "metaphysical assumptions" than one or other "way of writing." A work laden with obvious and canonical "metaphysical" theses can, in the operation of its writing, have more powerful "deconstructive" effects than a text proclaiming itself radically revolutionary without in any way affecting the norms or modes of traditional writing. (50)

For Derrida, reactionary or conservative discourses can sometimes have a greater power of "provocation, transgression or destabilization" than so-called "revolutionary" texts. A writing that seems to be simply metaphysical in its treatment of theological, philosophical, political assumptions and arguments might use language in a way that move more towards the revelation of the fragility and instability of assumptions, and in this way expose them more effectively. The paradoxical implications of a claimed nonradical text can sometimes open a reader's eyes to ruptures and fractures in metaphysical presuppositions. This, of course, remains in the hands of the reader and the way he approaches the text. The reader can make possible the recognition and revelation of these ruptures and fractures by determining their relations with the text. 
Derrida asserts that the "reader is not a consumer, a spectator, a visitor, not even a 'receiver"' (51). It is for this reason that a critical, leftist, and even deconstructionist text can be all conventional and metaphysical: "A critique presenting itself with 'deconstructionist' proclamations, theses or theorems can practice, if I may put it this way, the most conventional of readings" $(51) .^{57}$

Derrida views "the demonstration of literature's historical solidarity with the metaphysical tradition as an important task to be undertaken by literary critics" (53-4), but he adds that the demonstration here is "perhaps hinting at deconstruction." The "important task" of constantly recalling the historical solidarity of literature and the history or tradition of metaphysics is not only for literary critics but also for the writer of the literary text. He argues that this is "not necessarily a duty, in the moral or political sense, but in my opinion a task inherent in the experience of reading or writing" (54). The "imperative," in the experience of writing, is "to give space for singular events, to invent something new in the form of acts of writing [...] to give oneself to a poetico-literary performativity" (55), which are similar to the performativity we can experience in promises, orders, or acts of constitution and legislation. This singular event becomes possible only when the relations to the metaphysical assumptions are suspended in the process of writing, opening the space for new assumptions, theses, and conventions to appear.

\footnotetext{
${ }^{57}$ The emphasis here, in Derrida's argument, has similarities with the way Milton explores the claims of different groups and parties of his time. For Milton, the claim to be a catholic, protestant, etc. does not guarantee that the individuals making such a claim possess the qualities and attributes belonging to them. Sometimes, a catholic reader can be more truly critical than those who claim to be protestant or any other critical groups.
} 


\section{Fictionality of Literature and the Principle to Say Everything}

Metaphysical assumptions, Derrida argues, can reside in literature or reading literature in different ways. These assumptions "aren't faults, errors, sins or accidents that could be avoided" (49); instead their recurrence is "so structural" that any elimination would be pointless and impossible. The semantics and thematic of a literary text always carry some metaphysical or philosophical theses. Derrida's argumentation is that "literature's being-suspended neutralizes the 'assumption' which it carries; it has this capacity, even if the consciousness of the writer, interpreter or reader (and everyone plays all these roles in some way) can never render this capacity completely effective and present" (49, his emphasis).

Derrida differentiates between literature and fiction. The term "fiction" is terribly equivocal, Derrida asserts; although "not all literature is of the genre or the type of 'fiction"' (49), fictionality is in all literature. Literary texts have the capacity to suspend and neutralize metaphysical assumptions because of this element of fictionality. In his argument with Paul de Man, Derrida asserts that "all literary rhetoric in general is of itself deconstructive, practicing what you might call a sort of irony, an irony of detachment with regard to metaphysical belief or thesis, even when it apparently puts it forward" (50). In Derrida's thought, the institution of literature is radically different from other institutions: 
[...] literature seemed to me, in a confused way, to be the institution which allows one to say everything, in every way. The space of literature is not only that of an instituted fiction but also a fictive institution which in principle allows one to say everything. To say everything is no doubt to gather, by translating, all figures into one another, to totalize by formalizing, but to say everything is also to break out of [franchir] prohibitions. To affranchise oneself [s'affranchirl - in every field where law can lay down the law. The law of literature tends, in principle, to defy or lift the law. It therefore allows one to think the essence of the law in the experience of this 'everything to say.' It is an institution which tends to overflow the institution. (36)

To bring the terms "institution" and "fiction" together to account for the space of literature is no doubt problematic and contradictory. If the term "institution" dictates the necessity of laws and rules, the term "fiction" pushes us to the realms of dream and imagination. The space of literature is both imaginary and sustained by the regulatory work of institutions (instituted fiction), and productive because it stimulates regulation while suspending or subverting it by fiction (fictive institution). Literature cannot exist without being an institution, but it can also be fictive because of the fundamental principle to say everything - in both senses of exhausting totality and going beyond limitations and prohibitions. The radical freedom that one can experience within the space of literature is fundamental to Derrida's thought. This is the radical critique of the essence of the law. The experience of the space of literature is the experience of aporia. 


\section{Singularity of Literature and the Paradox of Iterability}

In his article "Aphorism Countertime," Derrida presents a reading of Shakespeare's Romeo and Juliet. Referring to this article, Attridge asks Derrida: "Does a literary work as historically and culturally distant as this one [Romeo and Juliet] pose any problem for your reading of it" (62)? Derrida's answer is 'yes' arguing that the historical reading of the play is "totally necessary" although it raises serious problems:

This brings us back to the question of the structure of a text in relation to history. Here the example of Shakespeare is magnificent. Who demonstrates better that texts fully conditioned by their history, loaded with history, and on historical themes, offer themselves so well for reading in historical contexts very distant from their time and place of origin, not only in the European twentieth century, but also in lending themselves to Japanese or Chinese productions and transpositions? (63)

Historical reading is the reconstitution of the text's "inscription in a chain of works" the history of its writing in the textual context of its time of production along with other texts produced before and after - and not just "the historicity of its composition by Shakespeare" (63). This historical reading is both necessary and difficult because of a text's "iterability;" a text "both puts down roots in the unity of a context and immediately opens this non-saturable context onto a recontextualization" (63). The structure of a text, like Romeo and Juliet, simultaneously demonstrates its roots in a 
context, which can never be fully recovered, and exposes that context to recontextualization. History is the story of recontextualization. Derrida argues that iterability as the very structure of a text is "the condition of historicity." The structure of writing or text makes history possible. All we have and know as history is the product of iterability, of the representation of events in language. Iterability establishes roots in a historical context, but it necessitates both repetition and alteration as well. It demonstrates something new and singular, but also belongs to the general, a category or sameness. It both repeats the same and "introduces into it what we call in French the jeu ["play," "give,"] not simply in the sense of the ludic, but also in the sense of that which, by the spacing between the pieces of an apparatus, allows for movement and articulation - which is to say for history, for better or for worse" (64, his emphasis). Iterability introduces a "play" into a text and makes impossible the fixity or purity of it. This "play" is something that sometimes "allows the machine to function normally" but sometime it is the cause of "malfunctioning."

The question is always one of an economic evaluation: what makes the "best play"? How far does "good" play, which makes things work, risk giving rise to "bad" play which compromises working well? Why, in wanting at all costs to avoid play, because it could be bad, do we also risk depriving ourselves of "good" play, which is as much as to say of everything, at least of a minimal functioning or so-called "normal" functioning, in particular of writing, reading, history, etc.? (64-65) 
To prevent the play of language, text, or writing by anchoring some meaning would prevent the good play in their structure. His reading of Romeo and Juliet would not "reconstitute all the history" but no one is capable of doing such an impossible task. He insists that his reading of the play is not to make "a model," but that he has written on "the singularity of the play." Derrida asserts that he "wanted to say that Romeo and Juliet is not the only example but that it's a very good example. Its singularity should not escape us even if, like any singularity, it is a singularity among others [...] What is tragically and happily universal here is absolute singularity" (65). Derrida declares his law as the following: "My law, the one to which I try to devote myself or to respond, is the text of the other, its very singularity, its idiom, its appeal which precedes me" (67, his emphasis). Derrida points out that the singularity of a work can be referred to as a proper name "and whatever irreplaceable reference a proper name bears within it" (67):

Attention to history, context, and genre is necessitated, and not contradicted, by this singularity, by the date and the signature of the work: not the date and signature which might be inscribed on the external border of the work or around it, but the ones which constitute or institute the very body of the work, on the edge between the "inside" and the "outside." (68, his emphasis)

The singularity of a text upon which literary criticism comments is not absolute and "never given as a fact or object or existing thing in itself" (68). It is "always singularization," this is the singularity of a work as becoming rather than being. Derrida argues that if there were any absolute singularity it "would not even show up, or at least 
would not be available for reading. To become readable, it has to be divided, to participate and belong" (68, his emphasis). Based on "the law of iterability," a work is both singular and general. It separates itself from the same type, genre, or sameness as singular but simultaneously attaches itself to them, introducing itself as a member of the same.

Singularity is never one-off [ponctuelle], never closed like a point or a fist [poing]. It is a mark [trait], a differential mark, and different from itself: different with itself. Singularity differs from itself, it is deferred [se differe] so as to be what it is and to be repeated in its very singularity. There would be no reading of the work - nor any writing to start with - without this iterability. (68, his emphasis)

In his discussion on the possible differentiation between writing as literature and reading as literary criticism, Derrida argues that writing is "also already a countersigning reading" (69). Any writing has to connect itself to other writings and readings. There is always the evidence of others in a written work, which makes it a reading of others. A text is singular as both reading and writing. No reading would be possible without the possibility of countersigning; that is, the law of iterability. He asserts:

There is as it were a duel of singularities, a duel of writing and reading, in the course of which a countersignature comes both to confirm, repeat, and 
respect the signature of the other, of the "original" work, and to lead it off elsewhere, so running the risk of betraying it, having to betray it in a certain way so as to respect it, through the invention of another signature just as singular. $[\ldots]$ this experience always implies more than two signatures. (69, his emphasis)

Therefore, no reading "would be 'new,' 'inaugural,' 'performative,' without this multiplicity or proliferation of countersignatures" (69). A literary text like Romeo and Juliet with Shakespeare's signature takes place only once. It is a singular text like others and the constitution of its singularity is due to "the possibility of its own repetition." Repetition, to Derrida, can be "readings, indefinite number of productions, references, are they reproductive, citational, or transformative" (69). Derrida argues that it is very important to take account of this uniqueness in all readings, but to do this one must sign one's own reading. To take account of the singularity of a text one needs to write something else:

[...] which responds or corresponds in an equally singular, which is to say irreducible, irreplaceable, "new" way: neither imitation, nor reproduction, nor metalanguage. This countersigning response, this countersignature which is responsible (for itself and for the other), says "yes" to the work, and again "yes, this work was there before me, without me, I testify," [...] The countersignature of the other text is held under the law of the first, of its absolute pastness. But this absolute pastness was already the demand for the 
countersigning reading. The first only inaugurates from after, and as the expectation of, the second countersignature. What we have here is an incalculable scene $[\ldots]$. ( 70 , his emphasis)

\section{The History of a Ruin}

Among Derrida's works, there are several that have been written on specific literary texts. He asserts that the reason for his selection of those literary works to write on is that they all have something in common: "they are written in a critical experience of literature" (41, his emphasis). He argues that "in their literary act they put to work a question, the same one, but each time singular and put to work otherwise: "What is literature," "Where does literature come from," or "What should we do with literature" (41)? These texts, he asserts, put to work "a thinking about their own possibility" (412):

[Literature] began with a certain relation to its own institutionality, i.e., its fragility, its absence of specificity, its absence of object. The question of its origin was immediately the question of its end. Its history is constructed like the ruin of a monument which basically never existed. It is the history of a ruin, the narrative of a memory which produces the event to be told and which will never have been present. (42, his emphasis) 
Derrida argues that "literature" started when some texts written in conventional literary form began to pose the question of "what is literature," and the critical relation between the literary text and the institutionality of literature was established. He asserts that the questions put by literary texts are "linked to the act of a literary performativity and a critical performativity (or even a performativity in crisis)" (42). The worries or desires of such texts are "to put into play or to keep the singularity of the date (what does not return, what is not repeated, promised experience of memory as promise, experience of ruin or ashes)" (42), and simultaneously, "through the same gesture, to question, analyze, transform this strange contradiction, this institutionless institution" (42). Derrida refers to this economic power as language, as writing. The literary text can achieve this complex work because of what Derrida calls its economic power:

A text by Joyce is simultaneously the condensation of a scarcely delimitable history. But this condensation of history, of language, of the encyclopaedia, remains here indissociable from an absolutely singular event, an absolutely singular signature, and therefore also of a date, of a language, of an autobiographical inscription. In a minimal autobiographical trait can be gathered the greatest potentiality of historical, theoretical, linguistic, philosophical culture. (43, his emphasis)

A literary text can become "an absolutely singular event," a condensation of history, language, and inherited knowledge. A verbal structure, which is organised in such a way, has an extraordinary economy in a sense of the organization and management of 
its diverse/complex resources. For Derrida, the economy of literature "sometimes seems to [him] more powerful than that of other types of discourse: such as, for example, historical or philosophical discourse. Sometimes: it depends on singularities and contexts. Literature would be potentially more potent" (43). In particular, literature for Derrida exposes the question of the future, a future irresponsible to expectations, calculations, and any moral, political, or ideological principles which constitute the rules of other institutions.

\section{Experience of Aporia and Democracy To-come}

Distinguishing between "literature" and "belles-letters" or "poetry," Derrida argues that different historical possibilities of each are responsible for important structural differences between them. By "belles-letters" or "poetry," he means Greek or Latin poetry, and non-European discursive works while "literature" for him is a modern institution. He indicates that one distinction is that "writing" was not indispensible for poetry or belles-letters; that is, writing as an 'authorial property' or 'individual signature' was not was not essential for those works which were in oral form. Derrida states:

The set of laws or conventions which fixed what we call literature in modernity was not indispensible for poetic works to circulate. Greek or Latin poetry, non-European discursive works, do not, it seems to me, strictly speaking belong to literature. One can say that without reducing at all the respect or the admiration they are due. If the institutional or socio-political 
space of literary production as such is a recent thing, it does not simply surround works, it affects them in their very structure [...]. (40)

In addition, literature is different from poetry or belles-letters because its "institutional or socio-political space" of production is different. Derrida emphasises the significance of context in which the literary work is produced for the reason of which he uses the term "literature" for the texts produced in the modern West. The modern institution of literature enjoys the distinctive feature of the principle to say everything:

The principle (I stress that it's a principle) of "being able to say everything," the socio-juridico-politico guarantee granted "in principle" to literature, is something which did not mean much, or not that, in Graeco-Latin culture and a fortiori in a non-Western culture. Which does not mean that the West has ever respected this principle: but at least here or there it has set it up as a principle. (40-1, his emphasis)

The principle to say everything is the reason for the different literary productions for which Derrida uses the term "literature." He connects his particular notion of literature to democratic structures and institutions and the modern concept of democracy; with this principle, literature binds its destiny to a certain kind of noncensorship, to the space of democratic freedoms (freedom of the press, freedom of speech, etc.). The emphasis on this principle demonstrates the significance of the notion of radical critique in his argument. Whatever the conventions and rules of 
literary productions, this "institution of fiction [...] gives in principle the power to say everything, to break free of the rules, to displace them, and thereby to institute, to invent and even to suspect the traditional difference between nature and institution, nature and conventional law, nature and history" (37, his emphasis). The fundamental questions in the modern institution of literature, Derrida argues, are "juridical and political" (37), linked to "an authorization to say everything, and doubtless too to the coming about of the modern idea of democracy" (37).

However, this does not mean that Derrida regards literature all dependant on democracy; for him, literature seems inseparable "from what calls forth a democracy, in the most open (and doubtless itself to come) sense of democracy" (37). It is the desire which calls for the experience of aporia, justice, and deconstruction. However, this authorization of literature in modern times remains very ambiguous and incomplete. The principle to say everything gives literature a "critico-political function;" therefore, the lifting of censorship is closely linked to the origin and institution of literature in the West. It is a radical freedom and "a very powerful political weapon, but one which might immediately let itself be neutralized as a fiction" (38). It is a "revolutionary power" that asks for a responsibility in the form of a "certain irresponsibility" against ideological powers which try to call one back "to extremely determinate responsibilities before socio-political or ideological bodies" (38). Derrida indicates:

This duty of irresponsibility, of refusing to reply for one's thought or writing to constituted powers, is perhaps the highest form of responsibility. To 
whom, to what? That's the whole question of the future or the event promised by or to such an experience, what I was just calling the democracy to come. Not the democracy of tomorrow, not a future democracy which will be present tomorrow but one whose concept is linked to the to-come [avenir, cf. avenir, future], to the experience of a promise engaged, that is always an endless promise. (38, his emphasis)

Derrida argues that the desire to write literature, as he defines it, is inseparable from the desire to experience the promise of democracy to come. The experience of this revolutionary principle can occur in the space of literature because it necessities a radical irresponsibility in the realm of aporia. The experience of aporia is the possible experience of impossible justice, truth, deconstruction, and democracy to-come, when it opens out on to the future rather than being closed by a return to the calculable, the established and accessible forms of them. For Derrida, the distinctive attribute of what "we call literature (not belles-lettres or poetry) [is] that license is given to the writer to say everything he wants to or everything he can, while remaining shielded, safe from all censorship, be it religious or political" (37).

At the end of his interview with Derek Attridge, Derrida repeats the fundamental question of his argument, whether there is anything specific about literary writing that distinguishes it from other texts, asking about the possible "structures of textuality in literature." He argues that: 
Once you have situated the structure of textuality in general, you have to determine its becoming-literature, if I can put it like that, and then distinguish between fiction in general (not all fiction is literature, all literature is not strictly of the order of fiction), poetry and belles-lettres, the literature which has been called that for only a few centuries, etc. Also and this is just what we're talking about here - you have to discern exactly the historically determined phenomenon of social conventions and the institutions which give rise, give its place, to literature. (71)

The specificity of literature, its literariness, is "What literature 'does' with language," which holds a revealing power. This revealing power is not unique to literature and it shares it up to a point with law, and juridical language. Derrida asserts that such a power of language in literature "teaches us more, and even the 'essential,' about writing in general, about the philosophical or scientific (for example linguistic) limits of the interpretation of writing" (72). Due to this revealing power, the institution of literature "consists in transgressing and transforming, thus in producing its constitutional law; or to put it better, in producing discursive forms, 'works' and 'events' in which the very possibility of a fundamental constitution is at least 'fictionally' contested, threatened, deconstructed, presented in its very precariousness" (72). The revealing power has to do with the principle to say everything, with the radical freedom in the institution of literature, with threatening and deconstructing the current laws and rules in order to open the possibilities for truth, justice, and democracy to come. Therefore, literature "shares a certain power 
and a certain destiny with 'jurisdiction,' with the juridico-political production of institutional foundations, the constitutions of States, fundamental legislation, and even the theological-juridical performatives which occur at the origin of the law" (72). This is a radically critical and free moment/space which places itself outside the very frames and rules of systems and structures of the society. The law of literature does not imprison but frees the potentialities of language and makes those potentials of the play of language suppressed in philosophical, political, and other institutions come into existence. The experience of literature is the experience of the aporetic moment/space between deconstructible law and undeconstructible justice, between the calculable and the incalculable. The experience of literature is the experience and event of the very moment of aporia which exceeds the legislature and jurisdictional foundations, "interrogate them, 'fictionalize' them: with nothing, or almost nothing, in view, of course, and by producing events whose 'reality' or duration is never assured, but which by that very fact are more thought-provoking, if that still means something" (72) all for the sake of truth, justice, democracy, and humanity in the most unpredictable form, in the form of the to-come. What is exposed in literature is the question of the future, a future irresponsible to expectation or calculation and beyond the grasp of moral, political, ideological, or other norms. 


\section{Language, Writing, and the Possibility of Truth}

In Milton's thought, there was an Edenic condition in which truth was absolutely present and accessible. However, his understanding of the Fall demonstrates the loss of certain access to such truth. For him, the event of the Fall initiated an ongoing struggle and challenge to access absolute truth and original meaning for all generations of human beings in history. This will be the permanent "trial" that everyone must encounter and experience in order to get partial access to truth until Christ's Second Coming. After the original Sin, language is defective and faulty, and our duty and responsibility in the postlapsarian condition and life is to search for the scattered components of truth. The use of this fallen, broken language to recover some of the truth and justice is inevitable for humans in this world. In Paradise Lost, Raphael acknowledges the inevitability of using language for human understanding and the fact that it represents but cannot present what has actually happened. Although language is unable to present truth in its completeness, it has potentialities, complications, and play that make possible the partial revelation of it. In language, writing, and particularly poetry the secrets of the world might find the means to be revealed. Raphael asserts that:

High matter thou injoinst me, O prime of men,

Sad task and hard, for how shall I relate

To human sense th' invisible exploits

Of warring Spirits; how without remorse

The ruin of so many glorious once 
And perfet while they stood; how last unfould

The secrets of another World, perhaps

Not lawful to reveal? yet for thy good

This is dispenc't, and what surmounts the reach

Of human sense, I shall delineate so, (6.563-73)

There is good for humans in the practice of language. In her essay, "Naming, Paradise Lost, and the Gendered Discourse of Perfect Language Schemes," Kristen Poole argues that the "explosive emergence of print culture" and "the calamitous years of civil war" for a number of writers in the seventeenth century, like Milton, brought "an attendant self-consciousness of the fallibility, malleability, and corruptibility of human language." She asserts that this self-consciousness drove them to attempt to create a "steadfast, unambiguous language," a perfect transparent paradisiacal language. The conception of languages as fallible, corruptible, and potent resembles Derrida's notion of iterability and undecidability in language and writing. Poole contends that Milton's engagement with the perfect language movement of the period was more a disengagement and that, by creating "a literary laboratory for exploring linguistic theories and debates" (340) in Paradise Lost, Milton's intention was to show the diversity of the groups and relationships of this movement. Poole, then, quotes Stanley Fish's argument that "the poem [Paradise Lost] explodes the fantasy of postlapsarian readers being able to recover a prelapsarian linguistic purity, revealing the vanity of such an attempt" (340). 
The attempt to exercise language for recovering the truth, no matter how much partial and incomplete, is the only way to recover the parts of truth and justice in this world to which Milton throughout his life tries to make his contribution. In his works, he demonstrates that he primarily believes in the power of language or writing in general he writes with both hands himself even though he affirms his natural bent was in poetry. The desire that Milton is enthusiastically enacting in his writings, both prose and poetry, and throughout his lifetime, is for the critical and literary performativity, intentionality, and functionality of writing in general and poetry in particular, through the use of the radical, critical, and economical power of language. The desire to call forth fundamental conceptions of freedom, democracy, truth, and justice, become the main purpose and endeavour of his works in prose and poetry.

\section{Redemptive Power of Poetry}

Although, for Milton, language in general is the principal means for attempting the partial recovery of truth, poetry has a special place in his arguments and life. For Milton, poetry has a distinctive signifying power not only because of the specific qualities of poetic writing but because of the kind of engagement it makes possible with complicated socio-political issues and purposes. In her essay, "How Poetry Moves Readers," Barbara Lewalski argues that for Sidney, Spenser and Milton poetry has the capacity to move the audience to personal and political virtue; poets "develop a much more complex poetics of moving in their literary works $[\ldots]$ inviting readers to experience the passions, complexities, and conflicts that always attend moral and 
political choices" (756). Poetry is the experience of complexities in the process of writing, reading, and context, experience of a redemptive, revealing linguistic power. In her book, John Milton, Catherine Belsey argues that because the language of the Bible is the Word of God for Protestantism it works as a "redemptive text." Poetry for Milton, she says, is like preaching in its redemptive power:

The Bible is full of poetry. The "songs" of the Law and the Prophets are the result of poetic inspiration which, as the gift of God, may be found in all nations and at all times. Such songs "are of power beside the office of a pulpit, to imbreed and cherish in a great people the seeds of virtue." And Milton promises himself to contribute to this process with a work of significance, produced by inspiration, as a result of "devout prayer to that eternal Spirit who can enrich all utterance and knowledge, and sends out his seraphim with the hallowed fire of his altar to touch and purify the lips of whom he pleases." (20)

Milton's emphasis on "a great people" points to the political dimension of this redemptive work (democratic, free, critical text). Poetry can represent and redeem the truth of the Bible/the Word if the poet is inspired by the eternal Spirit, which signifies the principle to say more that what is already known. Conventional language employed by institutions and within institutions is reductive in many ways, but it is in poetry that the power and possibilities to say everything can become possible. The function of true poetry must be to affect the understanding of people, cherish them with seeds of virtue, 
and consequently change the socio-political life of individuals and society. In "How Poetry Moves Readers," Lewalski argues that in "the early 1640s Milton's supposition is that good literature might help produce a reformed culture that would repudiate subjection to bishops or monarchs and nurture liberty-loving citizens" (764). By writing poetry, Milton writes to contribute to this future, to the endless and performative process of representing truth and making possible a more humane and democratic society. Whatever Milton does, thinks, or writes is an engagement with texts in their present existence in history and their future possibility. Milton desires to release his writing from institutional norms and frames and he accomplishes this most fully in poetry. Milton's love of poetry and reading other texts as poetry is the love of being in a place where the secrets of the world might be revealed (6.563-73).

Poetry without this reforming purpose is not poetry in Milton's sense. When writing has this key feature, even if it is in the Word of God, it has to be called poetry. Evidence of Milton's contempt for poetry with no reforming social-political function and critique can be found in Eikonoklastes, when he refers to the King's book as mere poetry and calls Charles a 'poet' who attempts to trade in fiction: "I begun to think that the whole Book might perhaps be intended a peece of Poetrie. The words are good, the fiction smooth and cleanly; there wanted onely Rime" (406). Poetic writing which does not contribute towards a more humane and democratic future is not categorized as poetry in Milton's thought. 
Milton historically re-reads the western biblical tradition and interprets it in such a way that the relation between text, meaning, and referent is suspended. His reading of the Bible as poetry is the first step in his suspension of the highest textual authority and transcendent readings of it, which is most apparent in his controversial writing, like Christian Doctrine, where he was open to accusations of heresy. Milton, in Christian Doctrine and Paradise Lost, develops similar lines of thought but we know that they are fundamentally different. In his introduction to Christian Doctrine, John Rumrich states that had "Milton himself attempted to publish the treatise during the Restoration, its heretical contents would likely have caused him serious trouble, especially on account of his Arian rejection of the Trinity" (The Complete Poetry 1137). People read Paradise Lost for many years without finding it heretical, even though its theology is similar to that which Milton presents in Christine Doctrine. Rumrich asserts that even after "the recovery of the treatise in the nineteenth century, its Arianism provoked strong reaction, both from disappointed Christian readers (except, of course, Unitarians) and, during the last half of the twentieth century" (1138). As an unpublished theological text, Christine Doctrine is literature in the sense that its very existence remains in the to-come for many years and its mode of writing exemplifies the radical effects of literature on existing institutions. In terms of the exercise of the radical critique of institutional laws and conventions, Christine Doctrine is a piece of poetry (or literature according to Derrida); the element of fictionality protects the poet from the charge of heresy, and so it is possible to publish; that fiction is an aspect of what is understood to be poetry at the time which makes it possible to claim that the principle to say everything is at work in Milton's writing. 


\section{Anti-Tyrannical Work of the Right Hand}

Milton acknowledged prose as the work of the left hand, inferior to poetry as the right hand work. His metaphor brings forth the question of authority in writing. His aim to use this metaphor was to argue that the established forms of prose and discourse were institutionally limited therefore not the best means through which we can express our thoughts and meanings. The immediate theme in this regard is that of institutional control, in terms of the possibility both to avoid writing conventions and rules, and to write on different subject matters. Hereby, Milton emphasizes the singularity of the writer's intention who decides to write something either in prose or poetry which is open to the possible/the future. Difference comes into play when the person uses different hands, which signifies different extent of institutional curtailment in each case. Language as the used sign system is the same in each case, but when the person uses different hands a different range of attachments and detachments impose themselves. By this metaphor, the significance of the different discourses of institutions, and the singular context in which a person writes are highlighted. Milton asserts that poetry is more natural to him; however, both prose and poetry can be poetic/literary kinds of writing in his use of them. The important issue is the context of writing and the kind of relation to the reader which requires prose rather than verse an argument rather than narrative, in some cases. Milton here is thinking of institutional regulations and principles at work in different forms of prose and poetic writing that create and enforce restrictions and changes in the process of writing. To write with the left hand is troublesome if one is right-handed. Metaphorically speaking, the usual shapes of letters, 
words, and the whole format of the handwriting is deformed and distorted. These distortions, deformations, or even misrepresentations occur due to the different degrees of controllability and capability of hands. One can still write his argument or meaning in prose, but the institutional curbs and curtailments make the direct and potent revelation and expression of truth difficult and distorted. To write in poetry means fewer institutional restraints and more possibilities, potentialities, and freedoms. Milton metaphorically argues that if a writer wants to resist established theological relations between the meaning and referent they must write in poetry or the institution of literature as Derrida has defined it. ${ }^{58}$

A writer is supposed to maintain the features and conventions that are characteristic of a genre but can also vary some of them in a way that becomes an example of the notion of critique, as Milton does in challenging the classical epics, and his preference for blank verse. ${ }^{59}$ The experience of reading the blank verse of Paradise Lost is performative in the sense that it, in every moment of the poem, enacts the critique which presents writing in couplets as bondage, as a kind of imprisonment. Furthermore, reading the poem means also the performance of freedom from that imprisonment. John

\footnotetext{
${ }^{58}$ For the multiplicity of voices in Milton's poetry and questioning the authority of the text, see Catherine Belsey's John Milton: Language, Gender, Power, especially page 25.

${ }^{59}$ Sheridan Blau, in "Milton's Salvational Aesthetic," argues that "Milton did not simply adopt the critical theories of the Elizabethans, but he appropriated and transformed them for his own poetic intentions, and he developed a new conception of eloquence and the poet which would ultimately inform a new kind of poetry to serve the special purposes of a Puritan theocracy" (286). In "The Genres of Paradise Lost," Barbara Lewalski asserts that Milton uses a complex combination of different genres in order to create his own poetic vision and accomplish his conception of the poet as a "teacher and rhetor $[\ldots]$ to advance our understanding through a literary regimen at once intellectual and delightful."
} 
Creaser, in "Prosodic Style and Conceptions of Liberty in Milton and Marvell," in his comparison of John Milton and Andrew Marvell, indicates that "Milton presents all his writing as a defence of liberty in its manifold forms, 'because the gaining or loosing of libertie is the greatest change to better or to worse that may befall a nation under civil government' [...] Milton stands for freedom of form, and is always a conspicuous innovator as a prosodist" (1). Milton's poetry, according to his argument, "is throughout a prosody which rejects constraint for the sake of expressiveness. In the words of David Norbrook 'If this is a poetics, it is almost an anti-poetics, pushing conventional forms to the limit'" (2). By reading, the reader is performing the freedom that Milton says is integral to the use of blank verse.

If a literary law determines that a modern epic must be in heroic couplets, and that represents a formal constraint on the potentialities of writing, then both the reader and the writer are delimited and imprisoned. This is an example of literary performativity. It is also an example of a way by which a particular work can differentiate itself from the literary institution. When Milton affirms that the performance of epic in heroic couplets according to the rules of the time is associated with royalty, monarchy, and absolutism, then the politics of the statement and the politics of the mode of writing poetry also become apparent. His poem is a critique in performance because the claim is made at the beginning of the poem and the claim is there to be verified by the reader momentby-moment. Milton is creating a text, which is not suppressive, authoritative, or antityrannical. 
Milton's expression in Paradise Lost, "Things un-attempted yet,"60 (1.16) has been the source of controversy. The conventional interpretation of this expression is that Milton would like to create a poem greater than the epics of the past because of its greater truth-value. Such an achievement is recognized and authorized within the institutional and generic frameworks and evolution of poetry. This approach would be quite within the safe circle of the present institution of literature. However, another interpretation of the phrase is related to Milton's consciousness of what he is aiming to accomplish in the context of being on the verge of something to come, which falls outside the history of interpretations available to his time. He expressed his desire to write about "things unattempted yet," but his awareness and understanding of those things is revealed only as a horizon, as indeterminate, and unclear. ${ }^{61} \mathrm{He}$ deeply considers the conventions and conditions of writing and poetry known to him and the actual society in which he lives, but without complete knowledge of how different his performative act as poetic writing might be, precisely how it will come into existence or how it will be greater than others.

Milton positions his epic against the classical epics when in his early works he acknowledges his ambition to write a poem that would excel Homer and Virgil's great epics. He refers to their epics as fictitious poetic works. For him, Roman-Greco literary

\footnotetext{
${ }^{60}$ For more on different meanings of "things unattempted yet," see Daniel Shore's "Things Unattempted ... Yet Once More."

${ }^{61}$ See Irene Samuel's "Development of Milton's Poetics," in which she argues that while Milton wishes "to be an interpreter and relater of the best and sagest things among mine own citizens throughout this island in the mother dialect" he has not decided whether he will write an epic poem in the classical vein, a brief biblical epic, a romance, a tragedy, or odes and hymns, and, if an epic or romance "what king or knight, before the conquest, might be chosen in whom to lay the pattern of a Christian hero. All is tentative" (233).
} 
poetry does not achieve a salvational, social-political function and lacks the element of Christian revelation. In other words, the socio-political function of modern poetry is crucial for Milton; it must be radically democratic, universal, and Christian, assuming and suspending the institutional senses of these concepts. The fallen language has the potentiality to partially demonstrate truth provided that the Spirit illuminates fallen minds. ${ }^{62}$ In Paradise Lost, Urania is invoked by Milton to assist him to go beyond the horizon of his own knowledge and intellectual powers, illuminate the dark inside him so that he might be able to access the absolute truth. ${ }^{63}$ Such an impossible language and accessibility would become possible only when a divine source like Urania intervenes. For Milton, different discursive forms like literary, philosophical, and theological languages are associated with authorial interpretive obligations and restrictions. It is in the institution of poetry that such ideological and hegemonic forces applied to the text can be partially and temporarily suspended due to the possibility of saying everything in principle. Milton knows that it is impossible to recover the pure unequivocal language of Heaven, but such an impossible task becomes partially and poetically possible when a divine source of knowledge, like Urania, intervenes.

In his essay "Urania, antidote to tyranny," Matt Dolloff highlights the transforming nature of Urania in different representations when she is exposed to "the vicissitudes of ever-changing times and tastes and the idiosyncrasies of individual authors and readers"

\footnotetext{
${ }^{62}$ In The Reason of Church and Government, Milton thought that efforts to "sequester out of the world into Atlantick and European polities, which never can be drawn into use will not mend our condition," but that we should rather "ordain wisely as in this world of evill."

${ }^{63}$ See Matt Dolloff's "Urania, antidote to tyranny" in Milton in France.
} 
(155). He also emphasises the roles that Urania is apt to play: "most qualified to oppose tyranny and the sexual licentiousness of kings, even as she remained the vehicle for relating heavenly truths and divinely inspired poetry" (155). Classical poetry had always an inspiring source to invoke in order to reach meaning not ordinarily accessible to the poet, such as the nine Muses. In Paradise Lost, Milton uses the element of inspiration as well, but he modifies the classical tradition, which in his view, is limited and inadequate. He calls, instead, for Christian inspiration, 'the heavenly Muse', that is, 'the meaning, not the name:'

Descended from heaven Urania, by that name

If rightly thou art called, whose voice divine

Following, above the Olympian hill I soar, Above the flight of Pegasean wing.

The meaning not the name I call: for thou

Nor of the Muses nine, nor on the top

Of old Olympus $[\ldots](7.1-7)$

It is because of Urania that Milton claims to have access to the meaning or knowledge that is otherwise hidden. Such a potentially extensive access to secret knowledge for the inspired poet is consistent with Derrida's view that the law of literature is in principle the right to say everything, requiring openness to what exists beyond the present bounds of knowledge and thought. 


\section{$[\ldots]$ I thence}

Invoke thy aid to my adventrous Song,

That with no middle flight intends to soar

Above th' Aonian Mount, while it pursues

Things unattempted yet in Prose or Rhime. (1.12-16)

Milton here asks for a free, radical writing which has direct access to truth. No "middle flight" refers to theological, social, political agents of institutions that are at work to restrict, limit, and contain both the writer and the reader. It is in the work of the right hand that Urania can appear as the inner individual power making possible the freedom to critique the authoritative discursive laws and conventions of institutions.

\section{The "Fit" Experience of Language and the Poetics of the To-come}

Poetry and writing in general, for Milton, are matters of experience. To him, the involvement of the reader and the reading process is indispensible in bringing true poetry into existence. A literary text in Milton's sense introduces the to-come into the world through the engagement of the fit reader. It must exist in a form which preserves it for possible readers. The reading process is also a part of the functionality and performativity of poetry and writing in general. Writings need to be read and interpreted in order to come into existence and present themselves as performative acts. ${ }^{64} \mathrm{~A}$ fit

\footnotetext{
${ }^{64}$ Michael Fixler in his essay, "Milton's Passional Poetics, or Paradigms Lost and Regained," argues that poetry is an intersubjective experience of poetic text. He demonstrates that "Milton's aesthetics is focused
} 
reader can even read a writing by the left hand (prose) as poetry by being aware of the curtailing institutional forces of the text and suspending them. The notion of fit reader in Milton's thought has been interpreted as the skills, education, religious qualities, and other specific commitments and capabilities similar to Milton's. In Areopagitica, one of the grounds on which Milton bases his argument about the question of freedom of the press and a public space without conditions is the question of the reading process as a singularly intricate and context-related activity ${ }^{65}$ This essential process will be definitely affected and frustrated by any censorship. Fit readers in Milton's sense are aware of the complexity and irreducibility of the reading process and view the act of critical judgement as a radically singular and individual activity ${ }^{66}$

For Milton, the process and complicated experience of reading is indispensible for the identification of truth and justice. ${ }^{67}$ Writing, on the other hand, is itself a crucial component of the process of reading. Writing includes the reading of former writings; in fact, it is the reading itself. ${ }^{68}$ For Milton, reading (both writing and reading) is a

on his passional poetics, but not without its insistence that something written is always to be intersubjectively understood. (A community of readers consisting of just the writer and reader is complete!)" (106-07).

${ }^{65}$ See my argument in Chapter Two.

${ }^{66}$ See my discussion in Chapter Four about the elements of true judgment and the complexity of the reading/interpreting process for bad and good men in Milton's The Tenure.

${ }^{67}$ In "Poetry and Method in Milton 'of Education,"' William Riggs argues that poetry "is something inclusive, powerfully integral (as Rajan surmised), an experience to be shared and used by readers, critics, poets themselves. [...] Even here, I am arguing, special privilege means special exemption from the very sort of regulation promoted by the prescriptive poetics of Milton's age" (463).

${ }^{68}$ For a discussion on the process of defining himself (Milton) in his lyrics "as a poet, for him a role compounding reading with writing" (66), see Swaim, Kathleen M. "Myself a True Poem: Early Milton and the (Re)Formation of the Subject." Milton Studies (2000): 66. 
complicated, multilevel, and thoughtful process that must enjoy the elements of radical critique and freedoms of all sorts. The fit reader is a fundamentally free and critical interpreter that would not limit themselves to the laws of "customs" or power structures. The reading of a fit reader is the experience of a revolutionary moment/space, a trial in which the laws and conventions are suspended. It is a fundamentally critical moment/space of judgment and decision-making. Milton asks his fit readers to suspend any taken-for-granted laws or principles in reading a text in order to crucially release their reading from all these predetermined and established reading criteria. In Derrida's words, the fit reader exercises "non-transcendental reading" by primarily suspending transcendental reading. He wants his readers to interpret and read free from all these hegemonies and be radically critical in their reading of texts, even the Scriptures. This relation to a text is fundamental for the fit reader since it is only through such a radical process that true judgment/decision and interpretation of the text becomes possible. This radical relation to a text, in Derrida's terms, presents the fit reader's fundamental resistance to well-known metaphysical assumptions.

Julia Walker calls Milton's poetics "the poetics of antitext" because by "forcing us to misread his own text, to reread the source of his allusion, and finally to face the ambiguity generated by the antitext, Milton issues his readers an intellectual challenge of truly epic proportions" (152). ${ }^{69}$ Rejecting Fish's positions that Milton's text works as a trap for the reader and Harold Bloom's statement that Milton's text is "an oedipal error,"

\footnotetext{
${ }^{69}$ See Julia Walker's "The Poetics of Antitext and the Politics of Milton's Allusions."
} 
she accounts for Milton's texts and their use of allusion "as a deliberately constructed poetic of individual responsibility" (152). She concludes her essay as follows:

As Milton crafts these antitexts to conform to the spirit of his verse even as they are at odds with the letter of the passages in which they appear, not only is the poet overtly challenging the authority of the texts from which he takes his allusions, but he is at the same time establishing the power of the individual reader over the authorship of any text, even his own. For these allusions, these antitexts, are more than the sum of their parts only when they are taken up by the mind of an independent reader, a reader who will first question and then revise, a reader who will not be a heretic in the truth, a reader who will challenge all textual authority and in doing so will become truly free. That this freedom comes with more responsibility than we as readers might wish for is our problem. For as Milton worked to bring about a political reality in which the rights of the individual were liberated from traditional authority, so did he work as a poet to allow his readers intellectual independence from textual authority. $(169-70)$

Milton's works represent a fixity or common ground, which is about the aporetic moment/space of decision out of which true decision-making in the context of the tocome will be imaginable. His works give us the chance to explore by reading the very condition of such an aporetic moment/space full of indeterminacies and inconsistencies. 
He represents fundamental questions in his works in the form of unresolvable choices and aporias, since his aim is not to create suppressive and authoritative texts. Milton crucially emphasises the performativity of writing and more specifically poetry as the way to justice and truth. In other words, the absolute, undeconstructible desire for justice and truth represents itself as a certain indispensible responsibility for him, fit readers, and all "good men" who are determined to act for bringing more of the fragments of truth together in the world. Writing in general and poetry in particular are the fundamental means through which this desire can be expressed and fulfilled for the good of humanity.

Nonetheless, in contrast to the conventional interpretations of his approach, Milton does not attempt to represent and define truth or justice in his works. His attempt is to persistently immerse his reader in the problem of articulating the truth without permanently solving the problem for them. The element of indeterminacy, contradiction, and uncertainty has to do with an orientation towards the horizon of the future or the tocome. However, the engagement of the fit reader must result in more than experiencing indeterminacies and uncertainties because this is just the fundamental condition of the world. Fit readers go through the experience of uncertainty, indeterminacy before coming to a determinate conclusion in the form of an unpredictable, incalculable, singular decision. Eve's encounter with Satan in the temptation scene in Paradise is a good example of this aporetic situation, although she fails to decide and act like a fit reader. Other major characters in Milton's works, like the Son of God, Satan, Adam, Abdiel in Paradise Lost, the Son of God in Paradise Regained, and Samson in Samson 
Agonistes, are his exemplification of the experience of this moment of decision; a revolutionary moment of trial in which the individual needs to demonstrate the abilities and attributes of a fit reader in order to succeed in the trial.

Milton's notion of fitness is understood differently when it is explored and accounted for in relation to the ideal of writing as an experience rather than the fulfilment of a set of aesthetic laws. One experiences writing as poetry only when they desire to develop the quality of "fitness" which is the readiness to experience writing as an opening on the tocome. Poetry is a particular kind of writing that comes into existence in relation to this particular reader. In the light of his emphasis on the notion of fitness and openness to the to-come, Milton's works, both prose and poetry, are poetry/literature. Poetry is a text open to the to-come. A critical function of that text is to expose the reader to fundamental indeterminacies about their beliefs, thoughts, laws and maxims of their society in order to unlock the possibility of the future, rather than repeating the established accessible models and methods. The act of writing, which is open to the tocome and not about reproducing the already known, takes the writer and the reader into the problematic moment/space of indeterminacy.

A good example of fit reading at work is Andrew Marvell's reaction to Paradise Lost in the form of a prefatory poem. Marvell was an unquestionable admirer of Milton and his works and his short poem "On Paradise $\operatorname{Lost}^{170}$ represents Milton as knowing that what he is writing will be misunderstood by many readers who are unfit in his view. Marvell

\footnotetext{
${ }^{70}$ Marvell, Andrew, and N. Smith. The Poems of Andrew Marvell. Pearson Longman, 2003.
} 
acknowledges "misdoubting" (6) Milton's intent "That he would ruin (for I saw him strong) / The sacred truth to fable and old song (7-8). He explains that he "the success did fear" (12), but now he says "Pardon me, Mighty Poet" (23). He places Milton's poetry in the position of prophecies and heavenly words, taking the reader into domains that they would never think of. In the last stanza of his poem, Marvell accounts for Milton's deliberate refusal to use heroic couplets, the poetic form regarded as the grand form of poetic writing and to use blank verse instead. This is obviously a confirmation of the point that Milton performs poetry radically, critically, and freely in the way he understands it. Marvell's reading is an example of the fit reader at work.

In Milton's works, passages that account for his views on poetry are fragmentary and mostly occasional. He calls for a kind of poetry radically different from that available to his time. ${ }^{71}$ The established literary institutions of his time were adopting forms and conventions consistent with the political order of the Restoration, whereas Milton in his works frequently pushes the boundaries, conventions, and laws of these institutions. His poetics is more imaginable by this revolutionary desire to go beyond what is already available, institutionalized, and defined as poetry or writing in general. ${ }^{72}$ If Milton did not deliver a complete theory of poetry, this is a further evidence that what he was

\footnotetext{
${ }^{71}$ See William G. Riggs's "Poetry and Method in Milton 'of Education."' Riggs argues that in matters of education, "Milton envisions for poetry a 'glorious and magnificent use [...] both in divine and humane things' [...] So privileged, poetry comes to stand apart from the curricular system into which it is first introduced; it is not just distinguished from the arts (logic and rhetoric) with which it is initially grouped but disjoined from them to an extent that the relation of these arts does not provide secure access to a Miltonic theory of poetry" (445).

${ }^{72}$ See Barbara Lewalski's "Barbara K. Lewalski on Why Milton Matters," especially page 6.
} 
endeavouring to accomplish exceeded the categories available to him without his necessarily being confident that anyone subsequently would regard his work as great poetry. The element of "not-knowing" along with indeterminacies and uncertainties are the fundamentals of Milton's poetics. ${ }^{73}$ This means, undoubtedly, a revolutionary call for an absolute responsibility for truth, justice, humanity, and democracy in forms of the tocome. Milton's fit reading is a radical readiness to experience the to-come.

\section{The Holy Spirit and the Law of Literature}

In Areopagitica, Milton established a position for his fit reader by affirming the necessity of an alternative authority. For him, reason and conscience play the role of this authority supported and informed by the Holy Spirit which is an emphasis on the person's detachment from all external authorities. Milton is aware of the fact that we are living and operating in a historical epoch where direct access to truth and God's justice in human affairs is impossible. However, reason and conscience with the assistance of the Holy Spirit can make possible individual decisions/judgments that might culminate in some truth and justice. The crucial aspect of the Spirit is that its operation is entirely unpredictable following no institutional principles, rules, or laws. The experience of the presence of the Holy Spirit is absolutely private and individual. The decisive feature of the Spirit is that it is impalpable and ineffable, entirely the opposite of institutions,

\footnotetext{
${ }^{73}$ In "Poetry and Method,"" Riggs argues that "I wish only to suggest that in the early writings - and I include Of Education - an idealization of poetry is prominent, a sense of poetry as a mystery and a promise [..] To invoke poetry as a power yet to be fully engaged was liberating: it postponed the need for immediate fulfilment and cushioned, perhaps, the sense of immediate risk" (467).
} 
forms, laws, and the calculable. To Milton, the Holy Spirit is the source of ultimate authority for a fit reader. Truth and justice can partially appear through human beings since everyone can develop the capacities to hold the sword of justice and become a fit reader.

The institution of poetry is given a special place in Milton's thought considering the performative acts of writing and reading for the revelation of truth and justice in this world. Even the "letter" of the Scriptures does not have absolute access to the truth and it is not considered the absolute authority. ${ }^{74}$ The Spirit as the unpredictable and the indefinable must enlighten the poet to express the truth and "to be an interpreter \& relater of the best and sagest things" (The Reason of Church-Government). This is a matter of both writing and reading. In other words, the readers must also go beyond the already known reading models and approaches in order to locate themselves in a true moment/space of decision. The Spirit is the name for this inner radical and critical freedom that calls for the true meaning. In Christian Doctrine, Milton repeatedly asserts that "the Scriptures are both in themselves and through God's illumination absolutely clear;" therefore, they are the external authority for faith and "the authority of which we first have experience." The pre-eminent and supreme authority, however, "is the authority of the Spirit, which is internal, and the individual possession of each man."

In Paradise Lost, the poet/narrator invokes Urania to function as the authority to suspend all known reading and writing authorities and to take them beyond the present

\footnotetext{
${ }^{74}$ See Kari McBride and J. C. Ulreich's "Answerable Styles."
} 
knowledge and understanding. Her role and the freedoms she brings into his writing are similar to the principle to say everything in the modern institution of literature, to the law of literature. For Milton, fit readers are both writers and readers. In fact, every work of writing is produced through the process of reading other texts and contexts, and recording it in written form. The significant point here is that the Holy Spirit functions together with reason and conscience as the authorization for individual decisions and actions. Fit readers avoid institutional interpretive obligations and laws, suspend conventional ways for discovering truth, and open themselves to new possibilities and "Unattempted subjects yet in prose and verse" (1.16). This is mostly possible in the form of the radical self-authorization of saying everything in poetry/literature. The Holy Spirit is the name for this authority in Milton; it is the free, radical, critical, unpredictable, internal, singular possession of each man/writer/reader. The experience of this authorization is the experience of aporia, of a moment/space of fundamental uncertainties and indeterminacies, of suspending law and calling for truth and justice, of a moment/space which looks forward to the future in the form of an absolute responsibility towards and readiness for the to-come. 
Chapter Six

\section{The Aporetic Moment/Space of Decision and the Poetics of the To- come in Paradise Regained}

\section{Opening Chapters}

The overall objective of the previous chapters was to provide a clarification of certain aspects of the concepts of fit reader and democratic intellect in Milton and Derrida. The exploration of fundamental questions related to these concepts promisingly delivered the essential terminology to formulate a new understanding of Milton's writings. This juxtaposition offered the recognition of continuities, convergences, and affinities in their thought on the notions of fit reader/democratic intellect, radical critique, and the tocome. The texts examined foreshadowed the conceptions and conditions on which a better human society and humanity may be developed by locating an individual in the aporetic moment/space of decision, leading to a public act to introduce changes into the quality of public space.

Milton and Derrida reject exemplarity in favour of singularity. All singular examples in history are admirable figures with no exemplarity. Both thinkers affirm the indispensability of an unconditional public space beyond the known private/public space in which everything would be radically suspended and critiqued, a space of aporia 
within which nothing of the current body of knowledge is exempt from radical deconstruction. Milton calls for an ongoing radical critique of the law and all its socialpolitical embodiments. Radical critique takes place within the interval or aporetic moment/space between law and justice, between the calculable and the incalculable, with the aim being to make a true decision which can open up the possibilities in a society for democracy and humanity to come. True critique is impossible unless it is accomplished outside the frames and definitions of the eligible critiques dictated and authorized by power structures. At the time of true critique of violence, relations between the states, their laws, and people are fundamentally suspended, changed, and finally redefined, and the violence of the state and the law is revealed. For both Milton and Derrida, literature as a free institution has a special significance. It claims for itself the right to critique all institutions and their laws, even of its own. It is a modern democratic institution in which the principle to say everything is indispensible. In literature, the relation to meaning is suspended, and transcendental reading is profoundly resisted. The space of literature is an instance of the space of aporia, a public, democratic space in which the promise of justice can be given effect and its possibility can be envisaged and explored.

As discussed in the previous chapters, individuals' particular relation to society and structural powers is a key element for Milton and Derrida. The quality of relations determines the characteristics of democratic social-political relations and purposes. Milton affirms the quality of the individual decision-making process and represents the attributes and traits of the movement towards new forms of possibilities for human 
society and humanity to come. For both authors, there is no point in the private mental action unless it has the effect of modifying society in the direction of more democratic possibilities. Decision-making in the aporetic moment/space introduces the individual as a fit reader/democratic intellect who demonstrates willingness to be a means for the future to enter into the present. No one precisely knows what that future is. The openness to the to-come is the quality of absolute readiness to decide and act singularly and individually, not on the basis of pre-determination, group authorization, or certainty as to its outcome. Milton created a kind of literature that is pushing the boundaries of the question: what is required to realise democracy and humanity to come.

Milton's prose works elaborate the conditions of different instances of the aporetic moment/space of decision-making when uncertainties and indeterminacies produce unresolvable choices, represented as the moment of trial. A fit reader radically and critically reads and re-reads the aporetic situations pregnant with inescapable indeterminacies and unresolved choices, and reaches a decision specific to the context and situation. There is no absolute exemplarity or pre-programmed model of behaviour which can be applied universally. Milton represents singular conditions and attributes of fit reading in his poetic works. In the following two chapters, I will explore these notions in Milton's two late poems, Paradise Regained and Samson Agonistes.

In Paradise Lost, characters have direct or mediated access to the truth. In Milton's two late poems, the authoritative narrator is absent due to his emphasis on being in history after the Fall. The Son of God and Samson must decide and act in relation to what is to 
come even though they have no direct access to knowledge about the future. They must go through the process of decision-making in specific times and places in history without authoritative confirmation of their decisions. Derrida's concept of the aporetic moment/space of decision provides a different way of thinking about the two late poems as comparable and as having the same purpose, in contrast to much of the scholarship written on them. I will address the interpretive problem in recent Milton criticism on Paradise Regained and Samson Agonistes: how the sign of uncertainty or indeterminacy in Milton's thought is to be interpreted in the late two poems.

\section{Interpretive Problem}

The struggle in reading Milton's late two poems is how to describe the radical differences and contradictions between the central characters, the Son of God and Samson, one as a pacifist or quietist hero of non-action and the other as a violent antihero, a suicidal killer. Different camps in Milton criticism have argued for elimination of one and acceptance of the other as absolute, universal models. ${ }^{75}$ Is Milton's intention in writing the two poems to reject one central figure as an antihero and accept the other as an exemplary hero? Is it plausible to think that Milton endorses both characters? The scholar who has recently, most fully explored this dimension of Milton criticism is Peter Herman. In the last chapter of Destabilizing Milton, he argues that a group of critics has considered Paradise Regained and Samson Agonistes as the

\footnotetext{
${ }^{75}$ See John Carrey's "A Work in Praise of Terrorism?" and John Coffey's "Pacificist, Quietist, or Patient Milton? John Milton and the Restoration."
} 
conclusion of Milton's career: "a summa of his life's work - a crowning achievement that summons all his previous writings on stage for a final, brilliant affirmation and curtain call" (155, his emphasis). ${ }^{76}$ Milton himself disliked comments asserting the inferiority of his late two poems although attempts have been made to argue that Paradise Lost is the fulfilment of Milton's poetic ambitions and the latter short poems are inferior. However, from the very outset of their publication, critics have argued that after writing Paradise Lost Milton "had still more to say" (Destabilizing Milton 155); therefore, he wrote the last two poems. ${ }^{77}$ Herman's own argument is that the matter "is much more complicated, for in Paradise Regained, he conjures up the presence of his earlier work [Paradise Lost] not to confirm, but to dismiss it, and Samson Agonistes undoes whatever certainties Paradise Regained achieves" (155). His position is that Milton presents a poetics of incertitude in Paradise Lost, a poetics of certitude in Paradise Regained, and again a poetics of incertitude in Samson Agonistes undoing every certainty he has demonstrated in Paradise Regained.

Herman contends that the worlds of the Son of God and Samson are both unsatisfactory. Neither can be identified as a complete model of action to respond to the tyrannical undemocratic powers in the world. He asserts that "one cannot retreat from the world or

\footnotetext{
${ }^{76}$ See, for example, Samuel Glen Wong's "Echoes of Paradise: Epic Iteration in Milton" in Part Two: Reflections on the Sequel, and Anne Baynes Coiro's "Fable and Old Son: Samson Agonistes and the Idea of a Poetic Career." My argument here is to discuss Milton's two late poems as "crowning achievements" that demonstrate singular examples of Milton's notion of fit reader. It is in this sense that to me his late two poems are a summa of his life' work.

${ }^{77}$ See Arthur E. Barker's essay, "Calm Regained through Passion Spent: The Conclusions of the Miltonic Effort," in The Prison and the Pinnacle and also Balachandra Rajan's "'To Which is Added Samson Agonistes."
} 
reject the world's culture, as the Son does in Paradise Regained. The world will find you and the Son's embrace of strictly Biblical culture cannot be sustained" (175). Samson's world of mass slaughter is unsatisfactory as well. Herman's explanation for the contradictory juxtaposition of these worlds is that "[e]ach world requires the other, Samson requires the presence of a merciful deity, and Paradise Regained needs Samson's involvement in the world; yet, each world seems to rule out the other" (176). Herman's argument does not make sufficient sense of such fundamental contradictory elements between the two poems. At the end of his discussion of Samson Agonistes, he asserts that "At the very end of Samson Agonistes, we may very well be left with 'calm of mind all passion spent,' but questions linger, unanswered yet persistent" (176).

The Son of God and Samson experience similar doubts, uncertainties, and indeterminacies. Some critics have argued that the affirmation of faith by the Son of God in Paradise Regained can be the answer to the uncertainties and doubts that are declared by Samson but are not successfully resolved in his case. Herman argues that "Unlike Paradise Regained, in which doubts are raised only to be definitely answered, in his opening speech, [Samson's] doubts and assertions of faith alternate, with doubt in the end winning out, and this speech establishes a pattern for the rest of the poem" (164). There are differences between the poems in the extent to which the Son and Samson establish their positions in terms of their doubts and faiths. This does not mean that the signs of a divinely ordained mission are absolutely questioned and undermined by Samson's doubts, or are the source of a definitive plan of future action for the Son. It means that the singularity of each character's situation and context creates differences 
and discrepancies between the two poems and the terms by which the central figures understand themselves.

The Son of God and Samson are in the aporetic moments/space of decision-making but at quite different times in their lives. Their knowledge and its limitations, their experience and their faith are at work in a mental process of radically reviewing the crucial factors in their very different situations. The matter is not whether faith or doubt wins but that they are in similarly unsettled states of mind, uncertain about what must be accomplished as the final act or the fulfilment of their mission and responsibility. Their decisions are singular and the result of a fundamental inspection of the knowledge available to them. In the following two chapters, I will argue that Milton in Paradise Regained and Samson Agonistes presents the central characters as singular examples of his fit reader. In fact, the attributes and qualities he is attaching to the notion of the fit reader in his prose works are exhaustively gathered up and exemplified in these poems. My thesis is that Paradise Regained and Samson Agonistes are shaped by Milton's poetics of the to-come, each representing the aporetic moment/space of decision and emphasizing the singularity of each moment/space of decision and its enactment in each poem.

\section{The Poetics of the To-come in Paradise Regained}

There is a famous anecdote about the composition of Paradise Regained from the memoirs of Thomas Ellwood who was reading to Milton and was tutored in Latin in 
exchange. Milton gave him a manuscript of Paradise Lost and when he returned it, he indicated that "Thou hast said much here of Paradise Lost, but what hast thou to say of Paradise found" (Ellwood 90)? Milton did not say anything and later on when he gave Ellwood the manuscript of Paradise Regained, he asserted that "this is owing to you, for you put it into my head by the question you put to me at Chalfont, which before I had not thought of" (Ellwood 145). ${ }^{78}$ John Rumrich, in his introduction to Paradise Regained, referring to the anecdote, indicates that Milton did not respond to Ellwood's question because Ellwood had made him conscious about some spiritual defect in Paradise Lost, "but because he was momentarily stunned that a reader of Paradise Lost (and Ellwood must have been one of the first) could be so simpleminded as to charge it with having little or nothing to say of 'Paradise found"' (631). I agree with Rumrich's interpretation and will extend it to Samson Agonistes as well. Milton's anxiety that informed/educated readers of Paradise Lost like Thomas Ellwood would simply miss the core question of the work seems fundamental for his decision to compose the two late poems, Paradise Regained and Samson Agonistes. ${ }^{79}$ Milton's disagreement with those who judged Paradise Regained as inferior to Paradise Lost, in the very wake of its publication, is understandable if we consider this crucial anxiety of his.

\footnotetext{
${ }^{78}$ William Riley Parker in Milton: A Biography, and Barbara Lewalski in Life of Milton disagree with Ellwood's claim that he put the idea of writing the late two poetic works into Milton's head and that Paradise Lost does not say "of Paradise found."

${ }^{79}$ In addition, this seems also Milton's reason for the "magnificent plainness" ( The Complete Poetry 632) of his short epic. The use of language by a fit reader in order to think truly and justly seems imperative here. The language used in Paradise Lost has a rhetorical/poetic power to make imaginable the unimaginable. In the late short poems, Milton's concern is to write in a style appropriate to the mental work of the fit reader.
} 
John Rumrich notes that the two epic poems are connected "by their titles, their blank verse, their progression through Christian history, their focus on temptation [...] and the shared characters of Satan and the Son" (632), and that missing this element of connection "drove Milton to impatience when he heard that Lost was preferred to Regained: in his mind they were in some ways one work, not two" (632). In my argument here, I will explore the issue which I believe constitutes not only the principle element of connection between Paradise Lost and Paradise Regained, but which is also the fundamental common theme/concern of all Milton's works, both poetry and prose, but most importantly the late poetic masterpieces. I will argue that the principle element of connection is Milton's conception of the fit reader, as that conception is shaped by his poetics of the to-come. In Paradise Regained, he demonstrates that the attributes and qualities of his fit reader have to be acquired and developed through singular experience of an aporetic moment/space of decision, culminating in a true decision and its enactment for the sake of some possible truth, justice, democracy, or humanity to come. This is the core question of Paradise Regained, but it is also a question which preoccupied Milton's mind throughout his life.

Does the Son in Paradise Regained embody Milton's conception of how the fit reader should confront tyrannical powers and systems on earth? Does Milton intend to demonstrate that the only effective response to temptations and forces in the world is what is often understood to be the Son's non-violent action or passivity? Are we supposed to choose between what appear to be strongly contrasted models or examples like those he represents to us in Paradise Regained and Samson Agonistes? These 
questions have repeatedly arisen for readers of Paradise Regained due to the challenge posed by its juxtaposition with Samson Agonistes. Some critics like Peter Herman have argued that the Son's reaction is in fact a non-action. My argument is that the significance of what is happening in Paradise Regained lies in its treatment of the aporetic moment/space of decision and the notion of the to-come. I will be arguing that the Son's non-action is complementary to Samson's violent suicidal action, through both of which Milton demonstrates the qualities of his virtuous, fit reader. In Paradise Regained, the Son's method is a radically critical resistance against the known models of decision-making and action, exemplified by Satan's temptations. He is represented as a singular (not exemplary) example of a fit reader who is caught in an aporetic moment of decision, which is distinguished by indeterminacies and uncertainties driving from openness to the future and its difference from the present and past. Based on Milton's poetics of the to-come, the precise clarification of the to-come is impossible, yet it is only in relation to the to-come that true and just decisions become possible. Paradise Regained demonstrates both the singularity of the aporetic moment/space of decision and the generality of the characteristics of this unique moment/space. In fact, both Paradise Regained and Samson Agonistes demonstrate the common features of the aporetic moment of decision experienced by the central characters together with the manifold differences, which constitute the singularity of each moment in its specific time and place.

The focus of my argument will be on responding to two crucial questions: how does Milton represent the aporetic moment/space of decision in Paradise Regained, and what 
conditions does he establish for experiencing this moment for the central character and the reader? Accordingly, I will present my argument in two sections. The first section will demonstrate the distinctiveness of the aporetic moment/space of decision and the notion of the to-come through accounting for the Son's being in "the waste wilderness" or solitude, his mission to come, its mental-personal implications, and the way Milton frames this moment/space for the Son of God. The second section will demonstrate the Son of God's engagement with the radical act of critical reassessment of all resources of knowledge (moral, historical, social, political, personal, and so on) available to him within the specifics of his social and historical location and context. In this part, I will account for what is required to be a fit reader from Milton's perspective. That is, the radical review of all knowledge and factors relevant to the situation, the Son's selfcritique and question of prophecy, the rejection of the calculable, and the embodiment of the decision made by the Son of God which suspends any possible action while remaining in a state of absolute openness to the to-come and readiness to act.

\section{$\underline{\mathbf{I}}$}

If Milton's crucial attempt in Paradise Regained is to represent the singular aporetic moment/space of decision-making and the conditions for experiencing such a radical moment/space in order to move beyond the calculable, how does he demonstrate the distinctiveness and singularity of this moment/space in connection to the central character, the Son of God? Milton locates the Son of God and the reader in a 
problematic moment/space of his life on earth, in "the waste wilderness" replete with extremely tormenting thoughts and mental conflicts stimulated and augmented by Satan's temptations and persuasions. A crucial factor is his constant awareness of his divine mission and the prophecy that he will save humankind, which he accepts as his absolute responsibility.

\section{"the waste wilderness"}

One of the primary features of being in a situation of personal uncertainty, an aporetic moment/space of decision, is the experience of an intense mental conflict. This is both a private and public moment/space, which cannot be restricted to either and goes beyond them. At the very outset of Paradise Regained, the Son of God is shown leaving the public space of society and moving to "the waste wilderness," a deserted solitary and private space. To radically re-visit, re-question, re-examine, and re-assess laws, virtues, norms, principles, obligations, and knowledge is a fundamental feature of being in such a moment/space. The experience of this moment/space, from Milton's perspective, is absolutely essential for an individual who wants to become a fit reader. For that reason, Milton represents the central character, the Son of God, in such a radical state of mind.

The Son of God is entering a situation in which, in order to explore fully "his deep thoughts", it is "better to converse / With solitude" (1.190-91) far from the distractions and comforts of society. Milton puts his protagonist in a setting without human features, a "desert wild" with all signs of uncertainty, "dark shades and rocks environed round" 
(1.193-94), but for that reason a place in which he can pursue rigorously his thoughts and "holy Meditations." Metaphorically speaking, physical solitude in the wilderness brings him the opportunity to radically review his thoughts. A private solitude in thought is one in which one's mind becomes the sole object of one's attention and the most radical challenges are mental. The Son of God welcomes this exceedingly uncertain moment/place of wilderness within which all established virtues, laws, obligations, and principles are suspended and can be radically questioned. The opening lines of the poem refer directly to the singular event that is going to occur in the waste wilderness, which is also called "his victorious field" (1.9):

I who erewhile the happy garden sung,

By one man's disobedience lost, now sing

Recovered Paradise to all mankind,

By one man's firm obedience fully tried

Through all temptation, and the tempter foiled

In all his wiles, defeated and repulsed,

And Eden raised in the waste wilderness. (1.1-7)

Later in book 4, after the Son of God strongly repudiates Satan's temptations and persuasions, Satan ironically indicates that the Son of God belongs to the heart of nowhere. He asserts that the wilderness "For thee is fittest place, I found thee there, / And thither will return thee" (4.373-4). Satan is definitely angry about the Son's "nonbelonging" because he positions himself outside of all systems and metaphorically 
places himself in "wilderness," a metaphor for a place of uncertainties, suspensions, and indeterminacies, or in Derrida's term a space of aporia. The Son of God does not seek to escape from the wilderness because his inner private life is all that matters to him, and shapes his relationship with the world. He enacts his virtuous self in the wilderness and that becomes a precondition for what he might do in the future. However, this enactment does not then predetermine how he might act to fulfil his mission but confirms what are the inner qualities required to be "singularly good."

The wilderness metaphorically is the space of aporia, in which all matters of conscience, freedom, virtue, law, justice, and judgment come into play radically and critically. In this process, inner qualities and virtues are fundamentally significant and need to be asserted against the conventional ways and models of decision and action in the world which Satan presents to the Son in his temptations. Aspects of the truth, justice or humanity which better humans attempt to make known could not be discovered without the assertion of the inner domain. They result from contextually and morally oriented acts that are driven "Without ambition, war, or violence; / By deeds of peace, by wisdom eminent, / By patience, temperance;" (3.90-2).

\section{The Mission to Come and the Question of "What if"}

Paradise Regained demonstrates another distinctive feature of being in and experiencing the aporetic moment/space of decision, the prior acceptance of a mission or absolute responsibility which must be undertaken, but by means which are not predetermined or 
pre-programmed. This state of affairs, requiring future actions but without providing any precisely predetermined goal or method for accomplishing them imposes a heavy burden on an individual. To bear it, and succeed, requires becoming receptive to the tocome, which means acquiring the attributes of a fit reader so that experience of the aporetic moment/space of decision becomes characterised by a radically critical and free approach to all norms, laws, doctrines, and knowledge. Such an absolute responsibility engenders a radical irresponsibility in those individuals towards the established responsibilities and duties enforced by institutions and authorities in the societies in which they live.

At the very beginning of Paradise Regained, we read that the Son during his childhood was "Serious to learn and know, and thence to do" (203) for the sake of "public good." He thinks that he was "Born to that end, born to promote all truth, / All righteous things" (205-6). He also goes into the Temple to hear "The teachers of our Law, and to propose / What might improve my knowledge or their own;" (212-13). As we can read here, the Son is making sincere attempts to learn and improve his knowledge, which directly evinces his lack of absolute divine knowledge. In the world, he is definitely more the Son of man than of God ${ }^{80}$ These attempts do not complete his mission: "yet this not all / To which my Spirit aspired" (214-15). He refers to his overall mission and to how he thought that he must act as follows:

\footnotetext{
${ }^{80}$ See Michael Bryson's interesting essay "From Last Things to First" in Visionary Milton in which he argues that the key to understanding Paradise Regained is "in Milton's single most iconoclastic character - the human Jesus" (241, emphasis added).
} 
[...] victorious deeds

Flamed in my heart, heroic acts, one while

To rescue Israel from the Roman yoke,

Then to subdue and quell o'er all the earth

Brute violence and proud tyrannic power,

Till truth were freed, and equity restored: $(215-20)$

The Son of God will later reject these conventional ways of achievement, leading to his further search for more knowledge and different conception of his future. He never claims to know exactly about the ways and the appropriate time and place to accomplish his mission. After remembering his mother's words, he resumes his search and comes to a different understanding:

This having heard, strait I again revolved

The law and prophets, searching what was writ

Concerning the Messiah, to our scribes

Known partly, and soon found of whom they spake

I am; this chiefly, that my way must lie

Through many a hard assay even to the death,

Ere I the promised kingdom can attain,

Or work redemption for mankind, whose sins'

Full weight must be transferred upon my head. (259-67) 
The words and phrases, even the tone of expression here, are definitely not completely certain. The Son of God becomes aware of his identity as the Messiah, his mission, the nature of his responsibility, and that it will bring upon him many "a hard assay even to the death"; but he has no specific knowledge of what form these trials will take. It is after some assurance from "the Baptist" and other signs from God that he comes to this certain conclusion, which is more a statement of faith:

\author{
And now by some strong motion I am led \\ Into this wilderness, to what intent \\ I learn not yet, perhaps I need not know; \\ For what concerns my knowledge God reveals. (290-93)
}

There is no evidence here of his having acquired completely defined and clarified knowledge about his future. Instead, the Son of God acts here on the impulse of "some strong motion" rather than a definite plan; furthermore, he is looking into the future and opening himself to the to-come:

And he still on was led, but with such thoughts

Accompanied of things past and to come

Lodged in his breast, as well might recommend

Such solitude before choicest society. (299-302) 
The Son's decisions and acts are never predetermined or announced; there is only one thing he is certain of, that he must decide and act justly and freely. The Son is open to the immediate context in which he finds himself and this openness in addition to his inward qualities of virtue and knowledge is what demonstrates his readiness to decide and act justly in the to-come even though he lacks precise knowledge of how that tocome is going to be constituted. Milton demonstrates that even the Son would experience moments of uncertainty and indeterminacy, the moments of aporia. There is no simple logic which consistently connects present knowledge, a decision made on the basis of that knowledge, and actions implementing that decision.

A decision is not true or just unless it is taken freely. This is as true for Job, Abdiel, the Son, Satan, Adam and Eve, and Samson as it is for the Son of God. Without the possibility of error, there could not be a true decision. The Son could not be also the Son of man if he does not have free will. Milton reinterprets the nature of Sonship and the Son of God's relationship with Heaven and Earth in a way which emphasises the humanity of the Son rather than his divinity. ${ }^{81}$ In Paradise Regained, the Son is in history represented as having no supernatural or superhuman capacity to anticipate the future. He does not have the complete knowledge and vision of God. The Son's apparent passivity is because he needs to go through a mental process of decision-making (the scope of which includes "things past and to come") about the form of his mission and its future enactment. While the Son of God knows he has a mission, the only drive or force he feels certain about is to fulfil that mission and that it has to be in his own way,

${ }^{81}$ See Michael Bryson's "From Last Things to First." 
at a time, in a place, and by means that yet he does not know. He only knows that there will be a point in time when he must act on that mission. His use of the phrase "what if" here is very significant:

\author{
All things are best fulfilled in their due time, \\ And time there is for all things, Truth hath said: \\ If of my reign prophetic writ hath told, \\ That it shall never end, so when begin \\ The Father in his purpose hath decreed, \\ He in whose hand all times and seasons roll. \\ What if he hath decreed that I shall first \\ Be tried in humble state, and things adverse, \\ By tribulations, injuries, insults, \\ Contempts, and scorns, and snares, and violence, \\ Suffering, abstaining, quietly expecting \\ Without distrust or doubt, that he may know \\ What I can suffer, how obey? (3.182-194, emphases added)
}

Demonstrating his procedure here, the Son emphasizes the capability of thought to conceive possibilities and outcomes. He imagines the construction of possible situations for the future. Using the phrase "what if," Milton underlines both the significance of the element of indeterminacy and readiness to think and act differently. The Son's example produces a possible future which is not within Satan's calculations. Later, when Satan 
attempts to repeat his temptation of political ambition, the Son philosophically argues that no man knows the time and means of "gaining David's throne." At this point, Satan explains the Son's real situation of not knowing precisely the "when and how" of enacting the mission:

Did I not tell thee, if thou didst reject

The perfect season offered with my aid

To win thy destined seat, but wilt prolong

All to the push of fate, pursue thy way

Of gaining David's throne no man knows when,

For both the when and how is nowhere told,

Thou shalt be what thou art ordained, no doubt;

For angels have proclaimed it, but concealing

The time and means: each act is rightliest done,

Not when it must, but when it may be best. (4.467-76)

The "whenness" and "howness" of what it has been proclaimed is unknown to anyone and for this reason we must not, like Satan, expect the Son to act according to what our knowledge dictates of when and how he must act to fulfil his mission. This is a transcendent or logocentric reading of events, which blocks the way of truth and justice which partially manifest themselves in human lives and which Milton aims to deconstruct. For Milton, to define the time and the means of pursuing truth and justice in the world is to delimit them to the fixed rules and presuppositions of systems. Satan's 
concession that the "rightliest" act has to be achieved "when it may be best" totally confirms the Son's reason for not acting at the time and according to the means Satan proposes. We know that the Son avoids overthrowing tyrants because he believes there is a proper time for that; just because there are tyrants, deposing them does not need to take priority. The proper time is when the people have overthrown their inward tyrants, and so think and act freely enough to accept a democratic state and persistently keep protecting it. This is definitely what Milton seeks to tell the people of his time and human beings in general. Only inward freedom can guarantee the existence of a democratic state. Milton and those who shared his beliefs and supported parliament were trying to establish a free liberal democratic state but as he demonstrated in Eikonoklastes and was borne out by the restoration of the tyranny of the monarchy, popular devotion to the monarchy showed that the main precondition for establishing a democratic state, inner freedom, had not been achieved.

Herman argues that the Son confronted with Satan's temptations experiences complexities and uncertainties of the kind experienced in Paradise Lost, but the difference is that he is "quelling uncertainties with faith" (156). He argues that the allusions to Paradise Lost's uncertainties or their demonstration in Paradise Regained do not lead to the unresolved choices dominated by the poetics of incertitude, but they are developed here because Milton wants to suppress those uncertainties by the Son's faith. He quotes the following lines of the Son's first speech in Paradise Regained as evidence that the Son is "quelling his uncertainty with faith:" 
And now by some strong motion I am led

Into this wilderness, to what intend

I learn not yet, perhaps I need not know;

For what concerns my knowledge God reveals. (1.290-3)

Is it really possible to read these lines and come to this conclusion that the Son is thinking and acting with absolute certainty? The indefinite terms and expressions like "some," "I learn not yet," and "perhaps" would mean more as the indications of uncertainty and indeterminacy. Like the experience of the Spirit, the formulation of a "motion" as knowledge seems impossible. It is an impulse, motivation, or disposition to act without conscious content. The Son does not know exactly what the "strong motion" is that leads him; he has "learned not yet" about the intent of the action; he is not sure whether he needs to know about such things or not; he even does not know what would concern his knowledge. All of this is the evidence for a situation in which choice is radically uncertain. Considerable use of such expressions in Paradise Regained makes Herman's claim that "Doubt, in Paradise Regained, always resolves into certainty" (156) highly questionable.

Some critics have argued for the certainty in Paradise Regained. This has been achieved through the recognition of indeterminacies and uncertainties in the epic similar to those in Paradise Lost. For Herman, these uncertainties have been developed in Paradise Regained "only to be dispelled (155)." Herman argues that in Milton's short epic the allusions to the doubts and uncertainties of Paradise Lost are mainly to repudiate them, 
and that Paradise Regained has been written on the basis of the poetics of certitude rather than that of incertitude in Paradise Lost. My argument is that the complexities, uncertainties, and indeterminacies are present in Paradise Regained exactly for the reason or poetics that are put in Paradise Lost and other Milton's works. The indeterminacies and uncertainties in Milton's works are the consistent expression of "his poetics of the to-come." Milton is not fluctuating between the binary poles of certainty/incertitude in different stages of his life. I would argue that, in response to the changing social-political events of his time, Milton demonstrates a continuation of his poetics of the to-come, not only in Paradise Regained but also in Samson Agonistes, which is consistently manifested in his other works, prose and poetry.

\section{Framing the Moment/Space of Aporia}

In Paradise Regained, Milton frames the singularity of the moment/space of decision through the representation of unique events and characters in the poem. He demonstrates this moment/space by framing its singular space/time location between the social-historical present of the poem's setting and the to-come, and its singular personal-social location in the life span and consciousness/mind of the Son of God as a fit reader. This includes both the specific historical time and place in which the Son of God lives and the very private and singular specifics of his life and mentality. Milton focuses on the singularity of the aporetic moment/space of decision and the common features of the process of experiencing such a moment/space when the Son of God is 
attempting to become a fit reader and develop a radically critical and free approach to knowledge and interpretation.

The Son's uncertainty is manifested in his recognition that he cannot claim to know how, moment by moment, he should decide to act in ways, which will contribute to fulfilling his mission. This is not necessarily a negative state of mind. Rather, the positivity of such a frame of mind is essential to maintain readiness and openness. In the wilderness, he is in a uniquely indeterminate aporetic moment/space in which there is no specific circumstantial content to fully define or limit the terms and conditions of a decision. Such a moment/space is abundant with undecidables and indeterminacies and creates the possibility of experiencing complete openness of mind. In this state of mind judgments and decisions have no predictability but manifest the singular qualities of that mind and person. Satan's account in Book III gives an accurate description of the singularity of the Son's inner qualities or "God-like Virtues:"

I see thou know'st what is of use to know,

What best to say canst say, to do canst do;

Thy actions to thy words accord, thy words

To thy large heart give utterance due, thy heart

Contains of good, wise, just, the perfect shape. (3.7-11)

The Son - or any good man/fit virtuous reader - "knows what is of use to know" but definitely not everything. The source of the accordance of words and actions is his 
"large," "good," "wise," "just," and "perfect" heart. Satan truly acknowledges that the Son's inner personal and moral values and qualities belong to the private realm of his life and recognizes the determining importance of such a private life in opposition to the model of public life encouraged by him. This model emphasises action in the public realm to the end of creating personal glory and fame, which are significant aims for Satan's admired men. He tries to persuade him not to hide these "God-like Virtues" by just sticking to

Affecting private life, or more obscure

In savage wilderness, wherefore deprive

All earth her wonder at thy acts, thy self

The fame and glory, glory the reward. (3.22-5)

He urges him to do something praiseworthy in the eye of the public, but this source of valuation is of no interest to him. There is a crucial contrast between the Son's emphasis on private life and Satan's attempts to prioritize public life. This is not to say that the Son only values life in the private realm. The point is his emphasis on the indispensability of inner qualities and virtues as a fundamental precondition for achieving more of truth, justice, and humanity to come. The Son's life is represented in Paradise Regained in terms of his personal qualities and virtues and has no public dimension, although his future public mission is fully present to his mind. By contrast, Satan's historical exemplary heroes are those famous for desiring and achieving fame and glory in the public realm. His singular examples include those who have acted to 259 
gain "all dignities and powers" (3.30) and augment "the thirst of glory" (3.38) such as "the son / Of Macedonian Philip" (3.32) and "Great Julius." The Son examines Satan's examples and renounces them:

They err who count it glorious to subdue

By conquest far and wide, to overrun

Large countries, and in field great battles win,

Great cities by assault: what do these worthies,

But rob and spoil, burn, slaughter, and enslave

Peaceable nations, neighbouring or remote,

Made captive, yet deserving freedom more

Than those their conquerors, who leave behind

Nothing but ruin wheresoe're they rove,

And all the flourishing works of peace destroy,

Then swell with pride, and must be titled gods, (3.71-81)

The Son asserts that "glory," in Satan's terms, is "but the blaze of fame" (3.47) and "the people's praise" (3.48). He, instead, argues that public praise is of no value because the people are confused and do not base their praise on clear principles but on conformity to group opinion: "They praise and they admire they know not what; / And know not whom, but as one leads the other" (3.52-53). Delighting in such praise from the public, "To live upon their tongues and be their talk" (3.55), is unworthy from the Son's point of view. In fact, the true ground for praise is what generates dispraise from the public. 
True glory, in the Son's terms, belongs to one "who dares be singularly good" (3.57) and one who is "intelligent" and "wise" (3.58). ${ }^{82}$ To be "singularly good" is to be a fit reader/democratic intellect, a virtuous, just man. Milton exemplifies his fit readers in Paradise Regained through the Son and some biblical or historical figures. The Son's singular figures, unlike Satan's, are admirable primarily because of their private lives. Job and Socrates who were famous in Heaven are "on Earth less known; / Where glory is false glory" (3.68-9). The Son's fit, just, virtuous, democratic reader seeks glory differently:

But if there be in glory aught of good,

It may by means far different be attained

Without ambition, war, or violence;

By deeds of peace, by wisdom eminent,

By patience, temperance; I mention still

Him whom thy wrongs with saintly patience born,

Made famous in a land and times obscure;

Who names not now with honor patient Job?

Poor Socrates, (who next more memorable?)

By what he taught and suffered for so doing,

\footnotetext{
${ }^{82}$ In Samson Agonistes, Dalila contends that the meaning of events and actions is entirely subject to the interpretation of social-political structures and institutions. Like Satan, she argues that public praise and group opinion is of great importance to the meaning of actions (see lines 971-87). Her name "among the circumcised" (975) "may stand defamed / With malediction mentioned" (977-78), but in her country she "shall be named among the famousest / Of women, sung at solemn festivals" (982-83).
} 
For truth's sake suffering death unjust, lives now

Equal in fame to proudest conquerors. $(3,88-99)$

The Son demonstrates his affirmation of personal moral and intellectual qualities, knowing what it means to be good, virtuous, and just. The Son's "just man" is good only for the reason of being good in himself. He is not performing it in order to gain recognition and endorsement from systems or social-political communities and authorities. The Son's memorable characters act to reveal themselves; they act to affirm or confirm themselves. Job and Socrates are singular models available to others. The act of suffering for the truth places them in opposition to the powers of the world. The qualities of "Without ambition, war, or violence," "deeds of peace," "wisdom eminent," "patience," and "temperance" are exemplified by the Son of God himself. All these figures suffer for the sake of truth, justice, and humanity to come. In contrast, the personal reason for public action in Satan's terms is to achieve fame, political power, wealth, and glory.

The moral life of an individual as represented by the Son is given such emphasis by Milton because the possibility of democracy and the grounding of the fit reader's responsibility to act for the benefit of the public depend on it. The moral private life of a person is an individual quality which, in combination with others, determines the quality of a society. In this regard, the Son forsakes Satan's suggestion to overthrow the tyrants and release their people because the individuals of those kingdoms do not have 
the moral qualities and knowledge necessary to sustain a new social order of freedom and democracy:

Should I of these the liberty regard,

Who freed, as to their ancient patrimony,

Unhumbled, unrepentant, unreformed,

Headlong would follow; and to their gods perhaps

Of Bethel and of Dan? No, let them serve

Their enemies, who serve idols with God. (3.427-32)

What are the Son's grounds for these firm renunciations? Could it be an absolute certainty due to some divine revelation? My argument is that there is nothing predetermined about the Son's arguments against Satan; they exemplify fit reading by demonstrating the way a fit reader must develop interpretations of statements and events that are grounded in a radical process of analysis and are appropriate to the moment/space of decision and its unpredictability.

\section{II}

In this part, the focus of the argument will be on the identification of the qualities and attributes of the Son of God as a fit reader. I will demonstrate his engagement in the radical act of re-evaluation, re-examination, and re-assessment of all the resources of 
knowledge (moral, religious, historical, political, social, personal, etc.) he has access to within the particulars of his social and historical location and context. The crucial point is that Milton does not represent these attributes in the poem to provide us with a universal model of decision-making and action applicable to any radically problematic moment. His aim is rather to emphasize the importance of the aporetic moment/space of decision in the context of the to-come and the common features of such moments for a fit reader. The Son of God explores the aporetic moment/space of decision by radically questioning the available knowledge and the other personal and social factors which have created and contributed to his present situation in the wilderness. Furthermore, he considers the question of the prophecy and goes through a profound critique of his "self" and the absolute responsibility he has. The fundamental demonstration of his qualities as a fit reader is his repudiation of the calculable. The Son's full experience of the aporetic moment/space of decision will culminate in his complete refusal of all of Satan's models and the values associated with them in his decision to return home, thus suspending any immediate public action while carrying forward what has been achieved in the poem, a state of readiness to act and openness to the to-come.

In Paradise Regained, Milton draws our attention to the undecidability, indeterminacy, and suspension of meanings and concepts in the aporetic moment/space of decisionmaking. A fit reader, in Milton's sense, is not someone who passively follows the established and predetermined patterns, models, and examples of existing social systems. It is someone who radically practices the suspension of established laws, authorities and systems in the very moments of decision; who decides truly, justly, 
individually, and responsibly when ruptures and suspensions occur in a system, and who does this outside the conventional responsibilities of the time. Consistent with the poetics of the to-come, none of the processes and challenges represented in Paradise Regained predetermines how the Son of God might act in the next moment. From this perspective, the poem is a grand scale version of the aporetic moment/space that opens up every moment a decision is called for. On the one hand, Satan constantly pushes his demands, models, programs, obligations, and desires on the Son, and on the other hand, the inner qualities and virtues of the Son of God as a virtuous, just man, as a fit reader are revealed in his responses. This does not mean a refusal of the world, as Herman argues; it shows how a fit reader (the Son of God in this case) maintains a balanced relationship with the world. Accordingly, the Son does not reject the things of the world; he rejects the ways in which life in the world is valued, ranked, popularized, praised, or defined by human systems and structures. This endless task of balancing and choosing demonstrates itself in the moment/space of aporia in the wilderness.

\section{Exploration of Aporetic Moment/Space}

In Paradise Regained, the Son of God is shown deeply exploring his life, reviewing his acquired knowledge and the main personal and social factors which have contributed to his present situation. This is represented as an exploration of the aporetic moment/space of decision with its singularity in the Son's life. This radical review is an essential part of the process of becoming a fit reader. In his introduction to Paradise Regained, when referring to some examples in terms of leaving out "a good deal of crucial material in 
Paradise Regained" (634), Rumrich argues that "while Satan knows that Jesus is the woman's seed destined to bruise his head (1.64-65), he does not recognize in Jesus the Son of Book 6 of Paradise Lost" (634). He argues that:

Jesus also indicates no knowledge of those cosmic events. He understands by searching the Scriptures that he is the prophesied Messiah, destined to redeem humankind and deliver a weakening blow to Satan (I.259-67), but he does not realize that defeating Satan belongs to his divinity as much as to his humanity. John Carey insists that Jesus in his poem never acts as more than a man, albeit a perfect one $(1970,124-30)$. Nevertheless, this act of reading blocks out the cosmic dimension in the climactic irony. Satan and Jesus move toward a showdown on the pinnacle. The Son manifests his divinity; Satan reels in amazement. The moment recapitulates the climax of Paradise Lost's War in Heaven, as again Satan falls (or rather hurls himself, as before in $P L$ 6.8640-65), and again the victorious Son is hymned by angels. (634, emphases added)

According to Rumrich's argument above the Son's humanity explains why he lacks full knowledge of his redemptive capability. My argument is that Milton emphasizes the Son's humanity by having him experience an aporetic moment/space of decision and requiring him to make a true decision in the context of the to-come. This experience is indispensible for the fulfilment of his mission. Such a reading of the poem not only does not block out any aspects of the Son's divinity, but also reinforces the idea that as 
long as the Son is a man on the earth, the process of reaching a true and just decision means encountering and experiencing similar and singular human conditions and difficulties. In this poem, there is a reference to an inner awareness, knowledge, or "strong motion" the description of which always remains blurred, uncertain, and indeterminate, referred to as "something" which is unable to be expressed in words as known/knowable rather than apprehended.

\section{Self-critique and the Problem of Prophecy}

The radical exploration of a fit reader has critical relation to the present and affirmative openness to the future similar to the reading of prophets. The performative process of exploration includes a radical self-evaluation and self-critique. It is a private and mental process raised by a necessity to make a decision and act. The experience of the aporetic moment/space foregrounds the Son's humanity and enables a singular self-assessment. In Paradise Regained, Milton demonstrates the terms for this radical process of selfcritique, and argues that a true virtuous man rules over his inner desires and passions functioning as restricting rules of institutions on an individual through fundamentally critiquing them:

Yet he who reigns within himself, and rules

Passions, desires, and fears, is more a king;

Which every wise and virtuous man attains:

And who attains not, ill aspires to rule 
Cities of men, or head-strong multitudes,

Subject himself to anarchy within,

Or lawless passions in him, which he serves. (2.466-72)

In Paradise Regained, prophets are also referred to as singular examples due to their singular approaches of self-assessment and critique. The notion of prophecy in this poem is another example through the exploration of which the question of aporetic moment is emphatically developed. A prophetic character is supposed to have a secret knowledge about the future. The knowledge of the future is not, as has been traditionally explained, an authorization in form of prediction. In Paradise Regained, the prophetic connection is demonstrated as an aporetic connection within which there is no absolute certainty and determinacy about the future events. No prophet knows when they will prophesy or what they will prophesy. In this respect the status of prophecy is a well-known instance of the undecidability of the aporetic state of the to-come. In Book 1, the Son of God admits that his mother has told him about the prophecy:

A messenger from God foretold thy birth

Conceived in me a virgin, he foretold

Thou shouldst be great and sit on David's throne,

Any of thy kingdom there should be no end. (1.238-41)

He also remembers the reaction of John the Baptist that when he saw him he "Straight knew [him], and with loudest voice proclaimed / Me him [the Messiah] (for it was 
shown him so from Heav'n)" (1.275-76). After his baptism, the Son of God brings together Mary's and John the Baptist's knowledge about him, what he knows from his own study, and the confirmation of "Father's voice" and the Spirit like a dove to come to the full identification of himself as the Messiah:

Heaven opened her eternal doors, from whence

The Spirit descended on me like a dove,

And last the sum of all, my Father's voice,

Audibly heard from Heav'n, pronounced me his,

$\mathrm{M}$ his beloved Son, in whom alone

He was well pleased; by which I knew the time

Now full, $[\ldots[(1.281-87)$

At the beginning of Book 2, Simon and Andrew "Began to doubt, and doubted many days, / And as the days increased, increased their doubt" (2.11-12) and express their disappointment of missing the Messiah. They assert:

Now, now, for sure, deliverance is at hand,

The kingdom shall to Israel be restor'd:

Thus we rejoiced, but soon our joy is turned

Into perplexity and new amaze:

For whither is he gone, what accident

Hath rapt him from us? will he now retire 
After appearance, and again prolong

Our expectation? God of Israel,

Send thy Messiah forth, the time is come; $(2.35-43)$

These references mark the end of prophecy as prediction. If understood as prediction, prophecy does not necessitate any endeavouring or wilful attempt to make it happen. What remains in such a situation is passive waiting. However, Milton brings in a crucial element of prophecy which has to do with wilful endeavouring and individual responsibility to make it happen. There is a gap between the confirmation that he is the Messiah and the fulfilment of his prophecy. The struggle is no one knows (as Mary, Simon, Andrew, the Son of God, and Satan confirm) how the prophecy will be accomplished. Milton's response is the significance of "the Spirit of Truth" and "inward Oracle" (1.462-63) and "To all truth requisite for men to know" (1.464). The Son refers to Satan as the source of all oracles and that they are ambiguous with double sense and confusion:

Yet thou pretend'st to truth; all Oracles

By thee are giv'n, and what confessed more true

Among the nations? That hath been thy craft,

By mixing somewhat true to vent more lies.

But what have been thy answers, what but dark

Ambiguous and with double sense deluding, 
Which they who asked have seldom understood, And, not well understood, as good not known? (1.430-37)

It is only the "inward Oracle" that can bridge the gap and become a source of certainty. The prophecy is not in form of prediction. The uncertainty of not knowing the when and how forces Satan to argue that prediction supposes means emphasising the necessity to endeavour to obtain what has been prophesied, not just wait:

$[\ldots]$ thy Kingdom though foretold

By prophet or by angel, unless thou

Endeavor, as thy father David did,

Thou never shalt obtain; prediction still

In all things, and all men, supposes means;

Without means used, what it predicts revokes. (3.351-56)

Following my interpretation of the aporetic moment and the poetics of the to-come, prophecy is an instance of aporetic openness to the future and the extreme readiness of a radical, virtuous, democratic mind or intellect to act. A prophetic figure must always develop an extreme virtuous awareness and readiness in advance to enable them to receive or understand a prophecy and then reveal it. The grand Greco-Roman "Orators" are also nothing in comparison to "Prophets" because the latter are "divinely taught," (4.357) and they teach much better "the solid rules of civil government" (4.358). The significant difference between the works of prophets and orators of Greece and Rome is 
the "majestic unaffected style" (4.359) of the former. The attempt is the same, but the way or the style to demonstrate those teachings is different. It is through prophets' style that their teachings are represented supposedly in the "plainest" and "easiest" ways. Indeed, their style lacks the ambiguities, uncertainties, indeterminacies, and complexities of those of Greco-Roman ones. Such a performative style is "What makes a nation happy, and keeps it so" (4.362) in contrast to a style that "ruins kingdoms, and lays cities flat" (4.363). Milton links the style of speech with moral and spiritual quality, on the one hand, and with the truth as such, on the other. Truth in the world may go disguised, but truth as such is the streaming fountain and is fully revealed in the person of the Son. Mary considerably comments on the notion of plainness:

Sole but with holiest meditations fed,

Into himself descended, and at once

All his great work to come before him set;

How to begin, how to accomplish best

His end of being on Earth, and mission high: (2.110-14)

This argument has connection with the notion of prophecy because of the emphasis on descending into oneself, which is to be understood as the means by which one approaches to the fullest extent the truth as such. This is manifested in the individual by the Spirit of Truth and expressed in appropriate, plain language to demonstrate the truth as such. There is no doubt that Milton's fit reader and the prophets share many common characteristics. My contention is that the prophets are among the fittest readers for 
Milton and fit readers read, decide, and act in ways similar to prophets. The unique characteristic of prophets is their exceptional view or vision of the things happening in the world in relation to the to-come. The reading of a prophet is fundamentally similar to the reading of a fit reader due to its critical relation to the present and its openness to the future.

\section{Renunciation of the Calculable}

To become a fit reader, one needs to experience the possibilities in aporetic moments/spaces of decision, confront and forsake the fixed models and mandates of systems to open the time and place for a future-oriented decision and new possibilities of truth, justice and humanity. In Paradise Regained, Milton demonstrates the Son of God as becoming a fit reader by going through this process. He represents him as a singular example of one who repudiates all models offered to him by Satan in the wilderness, the renunciation of the calculable, and opens up the moment/space for the to-come. Satan's master project is to urge the Son to choose from established models of behaviour and action in order to turn him from his mission. Metaphorically speaking, Satan embodies the forces of human institutions and systems which are taken to be fundamentally firm and stable. However, the Son goes beyond social-political categorizations of systems as these evolved in human history. He represents a new approach in the form of how to be and how to remain a radically critical reader of these systems. For the Son this is an aporetic moment/space of decision in which he confronts and resists the laws, conventions, or mandates which have become established in society 
and are presented by Satan as authoritative models for thought and action. I will discuss each of Satan's temptations of the Son of God in separate sections below.

\section{"Might'st thou expel this monster from his Throne"}

In Paradise Regained, Milton uses a revolutionary language to explain the Son's earlier political ambitions. The Son speaks of:

[...] victorious deeds

Flamed in my heart, heroic acts; one while

To rescue Israel from the Roman yoke,

Then to subdue and quell o'er all the earth

Brute violence and proud tyrannic power, (1.215-19)

The aim of such a revolutionary strategy is to confront violence and tyranny until "truth were freed, and equity restored" (1. 220). Milton has referred to this strategy in his political pamphlets as well. To be more exact one can say that Milton's writing has always been directed towards such a prominent objective. As Herman truly mentions, according to Milton's prose works (I would extend his argument to his poetic works as well) "One has, in other words, a divine mandate to act" (158). This is the theme which is also repeated in the Son's early political ambitions and Satan urges him to act according to this divine mandate. Satan asserts: 
But to a kingdom thou art born, ordained

To sit upon thy father David's throne;

By mother's side thy father, though thy right

Be now in powerful hands, that will not part

Easily from possession won with arms;

Judaea now and all the promised land

Reduced a province under Roman yoke,

Obeys Tiberius; nor is always ruled

With temperate sway; (3.152-160)

It is the Son's "Duty to free" his kingdom from tyranny and he should not think that he could regain his "right by sitting still or thus retiring" (3.165). How is it that he urges his readers in his political pamphlets and in the youthful thinking of the Son in Paradise Regained to rise against tyrannical rulers and free themselves, but the Son of God declines to follow this course of action? My position in this regard is that the achievement of such objectives is context-based and therefore there is no single method to be successfully applied in all situations and cases. Satan repeats this temptation at the end of the epic when, in Book 4, he urges the Son to act to regain his promised kingdom and free his people by expelling the violent tyrants:

[...] with what ease

Endued with regal virtues as thou art, Appearing, and beginning noble deeds, 
Might'st thou expel this monster from his throne

Now made a sty, and in his place ascending

A victor people free from servile yoke! (4.97-102)

The Son's response to Satan's temptation to overthrow the "Emperor" who is now weak and unpopular enough to be removed easily is that he has to first "expel" Satan himself as the Devil who is responsible for the existence of such violent tyrants. This is a good example of the performativity of the Son's attitude and the contention that Satan is a symbol for the inner temptations and the inward battle against tyrannical forces that make us slaves both inwardly and outwardly. By rejecting Satan's persuasion, the Son demonstrates that he reviews and responds to radically the values and principles of human systems on earth. For him, the fight against Satan (inner conflict) is more imperative than overthrowing kingdoms and tyrannies when he says:

[...] then proceed'st to talk

Of the emperor, how easily subdued, How gloriously; I shall, thou say'st, expel

A brutish monster: what if I withal

Expel a devil who first made him such? (4.125-9)

The primary significance of inner liberty or conscience, for the Son, is because to become a fit reader is impossible if the inner freedom to think and decide does not exist. There is no use in establishing a democratic state for a people that would easily accept 
tyranny and slavery. In The Tenure, Milton argues that, for a nation to be free, its individual members must think and act freely like the "good man" or fit reader. ${ }^{83}$ The Son's response appears to be negative because he believes that it is not yet the time to carry out his mission: "All things are best fulfilled in their due time, / And time there is for all things, Truth has said" (3.182-83). In contrast to Herman's claim, I argue that the Son's strategy is not "passive suffering" (Destabilizing Milton 158) but active preparation. The Son affirms that "Who best / Can suffer, best can do; best reign" (3.194-5). The point is there is an appropriate time for action and the mandate to stand against tyranny does not mean at any time one is obliged to do this regardless of time and place. The Son knows that this is a noble action that brings justice to some communities, but he well aware of the fact that the singularity of the context of an action does not surrender to the generality of laws and mandates. Herman's position here is that the Son prefers the attitude Michael sets out in Book 12 of Paradise Lost that "fighting tyranny does not always entail God's full approval. Instead, according to Michael, tyranny is one of the consequences of the Fall" (158). Michael's lines are supportive of my argument in a different way:

[...] Therefore since he permits

Within himself unworthy powers to reign

Over free reason, God in judgement just

Subjects him from without to violent lords;

Who oft as undeservedly enthrall

\footnotetext{
${ }^{83}$ See my discussion in Chapter Four.
} 
His outward freedom: tyranny must be,

Though to the tyrant thereby no excuse.

Yet sometimes nations will decline so low

From virtue, which is reason, that no wrong,

But justice, and some fatal curse annexed

Deprives them of their outward liberty,

Their inward lost. (12.90-101)

It is after quoting these lines that Herman writes: "if tyranny must be, one has no right to take arms in the name of liberty or the Ancient Constitution" (158). Herman represents Michael's model as what the Son prefers in Paradise Regained. However, I think we must notice the temporality of such a model demonstrated by the use of "sometimes" which more fully defines the mandate as non-absolute. "Sometimes" stresses the significance of context, time, and place. My argument is that, if the Son, as Herman argues, "adopts exactly [Michael's] attitude" (158), it is not "for exactly the reasons Michael sets out," - that there must be tyranny, sometimes, because it is the consequence of the Fall - but it is because a fit reader must be radically critical of all mandates and laws and deconstruct their prescriptions rather than accepting them as absolute rules for thought and action. The Son, by referring to the importance of "time there is for all things" and the contextualization of decrees, laws, or so-called selfevident strategies, demonstrates the deconstructability of all laws. The Son shifts the focus of attention from the mandate itself to the complex issue of being able to identify correctly when such a mandate can best be acted upon. The problem is that there is no 
absolute model in the form of laws or mandates that can be applicable and followed in all situations. No systems of thought or doctrinal structures have been able to present such an absolute pattern throughout human history. The fact is we have to accept and respond to the call of absolute responsibility of becoming and remaining a fit reader, which needs on-going vigilance and constant radically critical work.

\section{"Get Riches first, get Wealth, and Treasure heap"}

In Book II, after trying the hunger temptation which was countered by the Son's firm repudiation, Satan argues that "Great acts require great means of enterprise" (412) and draws the Son's attention to his state of being "unknown, unfriended, low of birth," (413) and concludes that due to this poor life he could have no hope of achieving "high actions." Satan contends that "Money brings honor, friends, conquest, and realms" (422), an argument proved by what Antipater and his son Herod have done by usurping the throne that is the Son's right. As plainly represented in the following lines, Satan emphatically proposes this model or behaviour as an absolute formulation that is applicable to all situations and individuals:

$[\ldots]$ if at great things thou wouldst arrive,

Get riches first, get wealth, and treasure heap,

Not difficult, if thou hearken to me,

Riches are mine, fortune is in my hand; 
They whom I favour thrive in wealth amain,

While virtue, valor, wisdom, sit in want. (2.426-31)

The Son's response is once more the repudiation of such a supposedly well-know model and formula as the exemplary basis for his decision and action. He argues that wealth without "virtue, valor, wisdom" is "impotent." He rejects Satan's formulation by referring to the collapse of ancient empires with "all their flowing wealth" and singular examples of "highest deeds" accomplished "in lowest poverty;" such as Gideon and Jephtha, the Shepherd lad (King David), or even among the heathen, Quintius, Fabricius, Curius, and Regulus. Referring to these singular examples, the Son repudiates any unquestionable, universally applicable formulations because of the importance of context and the singularity of situations. After this argument, the Son accounts for his own desire and interest in terms of the poetics of the to-come:

And what in me seems wanting, but that I

May also in this poverty as soon

Accomplish what they did, perhaps and more? (2.450-2)

The Son feels responsible to enact something that he asserts it can be accomplished in poverty. He wants to do "something" like the high actions of those he referred to or perhaps more, but that "something" remains to come. The Son does not know whether that "something" will be similar to those accomplished before or "perhaps" greater than 
those. This "something" cannot be clarified or guaranteed by any formula like Satan's "money brings honour."

\section{Greco-Roman Knowledge and Academic Tradition}

After the rejection of politics by the Son, Satan tries to draw his attention to the importance and indispensability of classical knowledge. Flatteringly, he reminds him of his "childhood [that] shows the man, / As morning shows the day" (4.220-1) asserting that rather than "the kingdoms of this world" which are "transitory" (4.210 and 209), the Son is "addicted more / To contemplation and profound dispute" (4.213-4). Satan argues that if the Son wants to extend his "empire" he must "So let extend thy mind o'er all the world, / In knowledge, all things in it comprehend" (4.223-4). To learn the knowledge of others would help him "reason with them, how refute / Their idolisms, traditions, paradoxes"(4.233-4). It is then that he urges the Son to observe "Athens, the eye of Greece, mother of arts / and eloquence, native to famous wits" (4.240-1), to see there "the olive grove of Academe," (4.244), to view "The schools of ancient sages"(4.251), to "lend thine ear" (4.272) to the philosophy of Socrates. The invitation to read GrecoRoman knowledge and academic tradition is to acquire all the knowledge necessary for kingship in advance of establishing his actual kingdom. Satan indicates:

Till time mature thee to a kingdom's weight;

These rules will render thee a king complete

Within thy self, much more with empire joined. (4.282-4) 
Satan has accepted the Son's previous argument that it is not the time for him to overthrow tyrants and regain his promised kingdom and that a reformed kingdom requires a reformed king (and People). The Son's response to this temptation is again negative. Although, his answer is not that clear about whether he knows classical knowledge or not: "Think not but that I know these things, or think / I know them not" (4.286-7), it is obvious that he rules out everything in forms of earthly knowledge, learning, philosophy, literature and the like. He contends:

But these are false, or little else but dreams, Conjectures, fancies, built on nothing firm.

The first and wisest of them all professed

To know this only, that he nothing knew;

The next to fabling fell and smooth conceits, A third sort doubted all things, though plain sense; (4.291-6)

These lines indicate that the Son regards all human knowledge as fundamentally defective, imperfect, indeterminate, and uncertain. This approach is very similar to Derrida's deconstruction of the Western metaphysics. There is no absolute certainty about human knowledge. The Son emphatically argues for the priority of spiritually and morally transforming knowledge:

Alas what can they teach, and not mislead; 
Ignorant of themselves, of God much more,

And how the world began, and how man fell

Degraded by himself, on grace depending? (4.309-12)

Human knowledge will be always in desperate need of a supplement, which is for Milton a "Light from above, from the fountain of light" (4.289). The supplementary element of divine inspiration or spiritual enlightenment provides the foundation to access truth or justice. In the same discussion, the Son seemingly goes further and refers to "many books" as insignificant. The Son's argument demonstrates the essentials of being a "fit reader" by having true judgment, which derives from inner moral and spiritual qualities rather than extensive reading as an end in itself:

[...] However many books,

Wise men have said, are wearisome; who reads

Incessantly, and to his reading brings not

A spirit and judgment equal or superior,

(And what he brings, what needs he elsewhere seek)

Uncertain and unsettled still remains,

Deep-versed in books and shallow in himself,

Crude or intoxicate, collecting toys,

And trifles for choice matters, worth a sponge;

As children gathering pebbles on the shore. (4.321-330) 
The point is not that the Son completely repudiates the act of reading, learning and knowing. He emphasises the significance of a judgment assisted by a supplementary element that would shed light on the "uncertain and unsettled" knowledge of books. Without true judgment, the reader of all human knowledge or learning remains "shallow in himself." The reading process is not just the acquisition of the content of books, but a persistently inward struggle that requires ongoing vigilance and watchfulness. Milton's use of the term "judgment" conspicuously approaches Derrida's conception of the term decision. A true decision or judgment delivers itself as always other than calculation or predetermination which is crucial to - to bring together Milton and Derrida's terms virtuous, prophetic, fit, democratic readers.

Herman argues that the Son's renunciation of classical learning has created "a move that has occasioned a fair amount of embarrassment, especially among earlier critics for whom Milton figured as a monument of Christian humanism" (Destabilizing Milton 161). If Milton's position concerning classical learning is viewed through the notion of the poetics of the to-come and the question of exemplarity, no embarrassment remains for critics. The point for Milton is that no human knowledge is complete because it is the product of fallen minds and entrapped in complexities and imperfections of linguistic representation. No political systems, philosophy, literature, or humanities in general are able to provide absolute patterns, models or formulas for making true judgments or decisions in different situations. However, Milton is not pessimistic in regard to the possibility of truth and justice in the world. This means that every structure and system would be as imperfect and uncertain as it is valuable and helpful 
with some elements of truth and justice in it. This view would make the evaluation of systems and structures an ongoing process through which the discovery of more truth is always possible. No system, thought, or outstanding individual must be considered as exemplary in a way that could stop us thinking ahead, revisiting, and questioning their relevance to the future. Therefore, the embarrassment occurs if we think that Milton has accepted Christian humanism or any other system of thought as complete. If trust in knowledge, systems of thought and institutions is so absolute that it blinds us to their limitations, then their rejection by the Son, for example, would seem to be a mistake. However, if the trust roots in the possibility of new interpretations and extensions of knowledge, then the Son's rejection in the light of the poetics of the to-come makes sense. Milton's thought considering the freedom of printing and writing in Areopagitica is a good example to specify his particular approach in which the emphasis is not only on the singularity of books but also on their possible contribution to truth or justice to come.

Herman's position is that "the Son goes beyond rejecting classical learning. He rejects the efficacy of learning itself. Virtue precedes instruction, according to the Son, and the virtuous do not even need books to begin with" (161). If the "efficacy of learning" signifies the absolute exemplarity of learning (Satan's argument), I contend that Milton entirely rejects any absolute efficacy. On the other hand, if efficacy in Herman's statement means that the Son necessitates the element of virtue along with learning, my argument supports that. The element of virtue is exactly what Milton's fit reader needs to develop inside himself in order to be a radically critical and free reader and analyst. 
"Virtue precedes instruction" indicates the means by which we are led to Milton's poetics of the to-come. Virtue becomes a ground inside an individual, always different from one person to another, and practiced differently from one context to another. This is the inward quality that would prevent submission to institutionalized systems and their rules to make the exercise of true judgment possible, a form of judgment that is similar to what Derrida expects from a democratic intellect.

\section{Embodiment of Decision in a Public Action}

At the end of Paradise Regained, the angelic choir defines the moment as inaugurating the Son of God's "glorious work" when he will "begin to save mankind" (4.634-5). Nevertheless, the Son "unobserved / Home to his mother's house private returned" (4.638-9). Is this really the way to save mankind or to act for the public good, the goals he promulgates at the beginning of the poem? His final act does not seem to possess any sign of the grand objective of the glorious work of saving humankind. What he does is just return home. The Son's rejections and final action have been interpreted by a considerable number of critics as no action at all. ${ }^{84}$ However, the key to understand the Son's final (non)action is his performative act of not resigning to Satan's temptations. The Son's main objective is to radically critique known laws and systems and to show

\footnotetext{
${ }^{84}$ Peter Herman ends his discussion on Paradise Regained by this sentence that "In Paradise Regained, the only proper act is no act at all" (Destabilizing Milton 162). My position here supports Bryson's line of argument that the poem ends by emphasizing the paradise within and redefining true government "as knowing and worshiping God aright, as an inner government of the inner man" (The Tyranny of Heaven 170). I argue that everything comes to the individual inward existence of the fit reader which will ultimately lead to a public act and event.
} 
their non-absolute and non-exemplary nature. This critique will be possible only if he remains outside of systems and structures. He has come successfully out of his confrontation with Satan but the glorious task has yet to be accomplished. This glorious act is represented in Paradise Regained as a decision and event to come. The challenge between the Son of God and Satan occurs within the aporetic moment/space of decision. One of the main steps in experiencing such a moment/space is to renounce the established norms, laws, and models of institutions available in the very society in which individuals live. The poem narrates a mental process. What is considered as truth, justice, or humanity is informed and defined by the moment/space in which they are represented. But, at the end, the angelic choir commends the Son for what he has done:

[...] now thou hast avenged

Supplanted Adam, and by vanquishing

Temptation, hast regained lost Paradise, And frustrated the conquest fraudulent: (4.606-9)

Is this really an act? This appears to be the Son's achievement after all. The Son of God in Paradise Lost takes physical action against Satan and his army by casting them out of paradise, but in Paradise Regained, he is acting by vanquishing Satan's temptations, conquering powers inwardly and mentally. This is the profoundly problematic act of standing firm against the forces that would make us slaves of tyrants, forces which are moral, intellectual and social. The Son has regained Paradise within and his performative act leads to founding "a fairer paradise." Of course, this is not to say that 
the work has been totally completed. The way Milton finishes the epic emphasizes the ongoing practice of such a confrontation for every person at all times. The Son of God acts like a fit reader to demonstrate that the performativity of one's mental act is more influential and effective than outward action. To become and be a fit reader means to fundamentally free oneself mentally from regulations, principles and systems of thought. The Son is a singular example of what it means to find oneself in an aporetic moment/space of decision and the necessity of freeing oneself from inward tyrannies first and then outward ones.

Peter Herman argues that the Son says no to Satan's urges to act against tyrants and "he disavows his earlier political activism because the people like the Anglo-Saxons of the History of Britain and the backsliders of the Readie and Easie Way, no longer merit freedom" (159). In Herman's argument, that when people are inwardly "slaves," it would be useless to try to free them is definitely true as the Son indicates: "by themselves enslaved, / Or could of inward slaves make outward free?" (4.144-45). My argument is that the Son does not have a fixed pattern or attitude to save his people. Critics like Herman refer to the Son's "earlier political activism" as a model to free people from the yoke of tyranny. The Son acts at the very time of his confrontation emphasising the significance of the symbolic inward struggle. To save his people, first, means to show them the way they can release themselves from inward tyrannies and avoid being an "inward slave." Herman argues: 
One can hear in the Son's lines Milton's own disillusionment in the wake of the Restoration and English recidivism. Having overthrown and then restored a king, the English have shown themselves to be "inward slaves," not worthy of the freedom Milton (like the Son) offered them. Therefore, the only solution is to do nothing but wait for the Lord to intervene. The Son assures Satan that when the time comes, everyone will know it [...]. (Destabilizing Milton 159)

It is believable that Milton feels disappointed after the restoration of the monarchy but the solution "to do nothing" is not a solution at all. Milton's performative acts (his writings after the Restoration) are examples that reject this solution. The Son's response to Satan's temptations is a performative act of radical critical reading which is in the form of speech all through the poem, in the realm of language. From the outset, Satan thinks and acts politically and publicly. The Son thinks and acts individually. He performs himself in an act of ongoing exposure through the poem. The critical acts performed in the poem are those manifested and embodied in speech. The symbolic realm of social-political engagement becomes the realm of the Son's enactment throughout the poem. Because Herman does not consider articulated speech an act in itself, he like others represents the Son as completely inactive in Paradise Regained. In the last chapter of his book, Herman argues that Paradise Regained is a book of certitude and the poetics of incertitude in Paradise Lost has been replaced by the Son's "doctorial or interpretive certainty." He indicates that this interpretative certainty in Paradise Regained "does not lead to action" and in fact, according to the Son's 
(non)action, "the only proper act is not to act at all" (162). He claims, "There is only a 'single sense' in Paradise Regained, and that is because Milton replaces the poetics of incertitude with a poetics of certitude" (Destabilizing Milton 157). Herman concludes that in Paradise Regained "Milton gives up on the efficacy, let alone morality, of participating in the world" (157). Therefore, the Son's main strategy is "the refusal of the world and of all actions within the world" (162). He contends that the Son does not start his ministry and instead continues his "obscurity" because "he unobserved / Home to his mother's house private returned" (4.638-9). He quotes Michael Bryson's argument referring to two meanings of the term "private", that nobody witnessed the Son's return home and that the Son does not hold "public office or official position" (162). But as I argued above, the Son persistently pursues his mission through his confrontation with Satan. The Son performs his self primarily in private. At the end of the poem, the narrator uses the term "private" to emphasize his singular performative critique of the systems on earth and this time in a glorious form that is to come for the public good and for saving mankind. This particular ending underlines the argument that the poem locates itself in the inward realm of the Son's mind and that the actions accomplished are mental.

The Son demonstrates the qualities and attributes of being a fit, virtuous, or democratic reader. Unlike what Herman argues above, Paradise Regained is not a poem that refuses "the world, and of all actions within the world." Satan represents the conceptions of institutions, systems, and conventional thinking which the Son strongly rejects as prior models for acting out his mission. His actions would open to the to-come, in the sense 
of democracy, humanity, justice, or truth to come. None of these is predetermined by any known models or established structure. A true or just decision (not calculation) would be one that is not predetermined by previous rules or laws. Therefore, the Son acts on the symbolic level and performs his own self by these acts of thought and speech. He does not reject the world but his relation to the world is performed on the symbolic level and in private, in contrast to what Satan urges to be achieved in public and physical realm of conflicts and wars. The embodiment of the Son's decision is the suspension of possible action while remaining in a state of readiness to act. He has performed the actions characteristic of being in an aporetic moment/space, addressed the crucial mental conflicts and thoughts, reviewed radically the current knowledge available to him and his society, developed a profoundly self critique, and repudiated the calculable represented to him by Satan. To act in the realm of language is a symbolic rather than spectacular form of action. We need to remember that, in contrast to what Herman says, the Son is engaged in the most proper act in the context, which is the enactment of his virtuous self.

\section{Conclusion}

My argument in this chapter aims to account for the particular way Milton represents the aporetic moment/space of decision in Paradise Regained and the conditions he establishes in this poem for fully experiencing such a problematic but indispensible moment/space, in which it becomes possible to move beyond the calculable and deconstructible. I argue that the fundamental discovery of the poem is the nature of the 
radically free and critical state of the fit reader's mind as the premise for true decision and action. The poem positions the Son of God in an aporetic moment/space outside the conceptual and moral frames of the society in which he is located. He is in "the waste wilderness" developing mental capabilities to preserve radically and critically his private space of mind, judgment, and inward freedom. His inward life exemplifies the qualities of Milton's fit reader whose mind is radically at work, constantly in preparation and readiness for true decision-making and action. However, this readiness or inward freedom never adopts a predetermined course of action.

The aim of discussion was to demonstrate that the importance of what is happening in Paradise Regained, more than anything, lies in its treatment of the aporetic moment/space of decision and the notion of the to-come. The Son's radically critical resistance against the known ways and models of decision-making and action in the world exemplified by Satan's temptations, is a singular example of the way one must performatively practice fit reading in moments of aporia. An aporetic moment has certain distinctive characteristics, but its content is never the same. Wherever an aporetic moment is given content that content is absolutely a function of the very specific context in which it occurs. Paradise Regained is the narration of the significance of such a context. The experience of a truth at any moment is informed by the same moment. Although the Son of God believes that whenever essential the truth will be made available, he never claims to possess that absolute truth. 
The poetics of the to-come is Milton's dominant perspective by which he demonstrates the attributes and qualities of his fit reader in Paradise Regained. These qualities must be developed through experiencing an aporetic moment/space of decision which provides the basis for a true decision for the sake of some possible truth, justice, democracy, or humanity to come. Likewise, in the next chapter on Samson Agonistes, I will argue that the poetics of the to-come deeply informs Milton's conception of Samson Agonistes. Such a consistent perspective not only goes beyond Paradise Regained and Samson Agonistes but extends to all his works including his prose works. My claim is that both poems are however distinguished by the way in which they intensively develop the uniqueness and singularity of the aporetic moment/space of decision while also identifying its general characteristics. Both poems demonstrate the common features of the aporetic moment/space of decision but everything about that moment in each poem is made different by representing the elements that constitute the singularity of each moment. Milton has always aimed, in his works, to show the singularity of the aporetic moment/space of decision-making and the indispensability of going through this moment/space for becoming a fit reader. 
Chapter Seven

\section{The Aporetic Moment/Space of Decision and the Poetics of the To- come in Samson Agonistes}

The poetics of the to-come is the consistent element of connection between Milton's works, both poetry and prose, and particularly in his major poems: Paradise Lost, Paradise Regained, and Samson Agonistes. The focus of my argument concerning Paradise Regained was to identify the distinctive characteristics of this element in the poem while preserving the singularity of the Son's situation as Milton represents it. I will now make the case for reading Samson Agonistes in the same way. Milton identifies the qualities of his fit reader in relation to the poetics of the to-come in his two late poems through the central characters' experience of the aporetic moment/space of decision. To read the two poems from such a perspective leads to a new understanding of them. Peter Herman in his discussion of these poems formulates the fundamental issues and differences between the two poems as follows:

If, as Michael Bryson argues, at "the end of Paradise Regained, obedience is reasoned, internal, and given to oneself," then Samson asks what happens when inner promptings tell one to commit mass murder? If divinity is internalized, how does one know that it is God, and not Satan or even one's own madness, speaking? And assuming that God really is telling you to 
commit mass murder, what kind of a God is that? (Destabilizing Milton 175)

His answer to this interpretive problem is that there is only one option, not "to participate in the killing" which is the Son's "complete withdrawal" (Destabilizing Milton 175) at the end of Paradise Regained when he retreats to his mother's house. However, he continues to argue that:

Yet the events in Samson qualify that retreat by suggesting that the world will find you, regardless. In other words, Milton implicitly renders impossible the quietism at the end of Paradise Regained by the treachery of Dalila and active malevolence of Samson's enemies. On the other hand, Milton contrasts those who kill in Samson with those who save in Paradise Regained, using both figures to reinforce, yet once more, the proclamation of Paradise Regained that "to create / Is greater then created to destroy" (7.606-07). (Destabilizing Milton 175)

The evidence for this contradictory position can be explored in a different and productive way through consideration of the aporetic moment/space of decision and the notion of the to-come. The crucial issue that the poems present is not whether to practice Samson's mass murder or the Son's quietism, but the importance of going through the aporetic moment/space of decision, a private moment/space in which one is able to become a radically free, fit reader. To develop and practice such an inward 
freedom is the necessary foundation enabling an individual's self-authorization, true decision-making and the acceptance of absolute accountability.

Samson and the Son are not opposites; my contention is that they are singular examples of the concepts of fit reader/democratic intellect. To Milton, the two main figures have fundamental similarities and convergences provided that we read the poems as narratives of their singular journeys towards becoming a fit reader, and their actions and decisions as open to the future. My argument is that Milton's demand is not to ask his readers to accept or reject the Son or Samson and their decisions and actions as universally applicable models in the world. His aim is not to delimit the question of how to decide and act to either Samson's mass murdering or the Son's quietism. Through his poetics of the to-come, Milton locates the central characters on the edge of the unpredictable to come, the longer-term features of which may remain unclear to the individual himself.

The imperative of going through the aporetic moment/space of decision is an unquestionable condition for both the Son of God and Samson as fit readers/democratic intellects. Like the Son of God, Samson is in a moment of aporia within which he must rethink, re-examine, reinterpret, and redefine his relations with the existing systems and structures of his society and their related principles, laws, and conventions. He experiences mentally a deconstructive confrontation with the established norms and models of his society, a process which culminates in the demonstration of his singular inward freedom. To Milton, this is the indispensible condition for becoming a virtuous, 
democratic, and fit reader. In this sense, the Son of God and Samson are in similar but irreducibly singular situations in which even the presence of divine power becomes a matter of uncertainty and indeterminacy. I will argue that Samson Agonistes is a parallel poem to Paradise Regained due to similarities in their primary purpose, which is the significance of the aporetic moment/space of decision and the poetics of the to-come in the concept of the fit reader. I will explore the way these issues are demonstrated in this poem and argue that the poem's emphasis on singularity foregrounds the absolute responsibility of Samson and the context in which he makes his decision. The poem intensively develops the uniqueness and singularity of the moment, place, person, time, and circumstances, although in such a way that it also identifies the generality of the characteristics of the aporetic moment/space of decision and its openness to the tocome.

In this chapter, like the previous one, I will respond to two crucial questions: how does Milton represent the aporetic moment/space of decision and what conditions does he establish for experiencing this moment for both the central character and the reader? In the first section of the discussion, I will demonstrate the distinctiveness of the aporetic moment/space of decision and the notion of the poetics of the to-come by focusing on Samson's singular situation of being in solitude, his mission not accomplished yet with its mental-personal implications, and the way this moment/space for Samson is established. In the second section, I will focus on the demonstration of Samson's engagement in the performative act of radical questioning of all knowledge (moral, religious, historical, political, social, personal etc.) available to him within the 
particulars of his social and historical location and context. The attempt is to represent the attributes and qualities of a fit reader which include the radical appraisal of all knowledge and relevant contextual factors, Samson's self-critique and the question of prophecy, the refutation of the calculable, and the embodiment of the decision through creating an event.

Milton locates the main figure of his poem as well as the reader in a fundamentally singular and challenging moment/space of the last stages of Samson's life. He is located in "prison" and "solitude" - like the Son of God's situation in the "wilderness" - a tremendously intense condition within which he experiences extreme mental torment encouraged and intensified by the models and recommendations offered to him by people who are closely related to him in various ways. Samson reminds himself of his divine mission and the prophecy to save his people, which has been his life-long responsibility and has not been accomplished to this point late in his life. Milton frames this singular space-time as a singular social-historical location between the socialhistorical present and the to-come. The focus of the following arguments under this section will be on the representation of the particulars and essentials of Milton's representation of the distinctiveness of the aporetic moment/space and the notion of the to-come in Samson Agonistes. I will consider Samson's extreme situation in "prison" or "solitude," then I will focus on his divine mission and its personal/mental implications, 
and finally I will explore the ways Milton represents the aporetic moment/space of decision.

\section{Prison of Restless Thoughts}

At the beginning of the poem, Samson Agonistes, Samson describes his miserable situation in prison by contrast with the relief he feels as a result of his temporary release:

Daily in the common prison else enjoined me,

Where I a prisoner chained, scarce freely draw

The air imprisoned also, close and damp,

Unwholesome draught: but here I feel amends,

The breath of heav'n fresh-blowing, pure and sweet,

With day-spring born; here leave me to respire. (6-11)

John Rumrich in his footnote for these very first lines of the poem indicates: "In the first of many parallels with the companion poem, Samson like the Son of God retires to a place of solitude and is subject to swarming thoughts. The parallels also throw into relief fundamental differences between the heroes of the two poems" (The Complete Poetry 710). As demonstrated in the case of the Son of God in Paradise Regained, an unresolved state of mind in solitude is one of the primary features of being in the aporetic space/moment of decision. Milton locates Samson in a similar but singular 
moment/space in which all established knowledge, norms, laws, and principles can come into play and be radically critiqued by the fit reader. My argument here is that Milton creates the differences in the two poems because of his view of the historical singularity of each event.

In a totally miserable condition as a slave of his enemies, Samson feels something different that has signs of Heaven. Like the Son of God, he leaves the public, retires from "the popular noise", and moves to the deserted private. The Son goes into the "wilderness" and Samson seeks solitude:

Retiring from the popular noise, I seek

This unfrequented place to find some ease,

Ease to the body some, none to the mind

From restless thoughts, that like a deadly swarm

Of hornets armed, no sooner found alone,

But rush upon me thronging, and present

Times past, what once I was, and what am now. (16-22)

The conflicting thoughts would bring him to a state that he even complains about his creation and his special responsibility that makes him different from other people: "Why was my breeding ordered and prescribed / As of a person separate to God, / Designed for great exploits" (30-32). Later in his speech, Samson remembers his miseries and despairs again: "O dark, dark, dark, amid the blaze of noon, / Irrecoverably dark, total 
eclipse" (80-3) and this is without any hope. This is not a mind that due to an absolute loss of freedom would leave things unresolved to God and release himself from the burden of any responsibility and mission. My argument is that the whole poem, up to the very moment of Samson's ultimate decision to act, is the narration of a radically problematic mental and social situation for which Samson accepts full responsibility. The swarming thoughts, suggestions, and conceptions are stimulated in Samson by his own reflections but also through the closest figures around him. In his response to his father's offer to bring about his deliverance by ransom, he describes his tormenting situation as so severe because the pain he feels is mental:

O that Torment should not be confined

To the bodies wounds and sores

With maladies innumerable

In heart, head, breast, and reins;

But must secret passage find

To th' inmost mind,

There exercise all his fierce accidents, And on her purest spirits prey, As on entrails, joints, and limbs, With answerable pains, but more intense, Though void of corporal sense. (606-616) 
He indicates that such grief is not less painful than wounds and diseases like "gangrene" and "black mortification." In response to his father, and in grief, Samson can only envisage his situation hopelessly argues that his miseries are getting worse and worse; in saying "My hopes all flat" (595) he indicates that he cannot imagine any other possible future and emphatically laments the reality of his mental torments and miseries (606-616). The poem, like Paradise Regained, highlights a particular personal space distinct from the public realm in which the main character explores challenging issues of immediate present and future significance. Milton puts the main figures of his poems in this literal and metaphorical space to demonstrate its critical importance for the development and exercise of a radically critical and free mind.

\section{The Question of "What if" and the Unaccomplished Mission}

The awareness of an absolute responsibility is another indispensible aspect of the aporetic moment/space of decision experienced by Milton's fit reader and which Samson demonstrates. This awareness works on the individual as an unquestionable crucial persuasion, desire or inner force in the aporetic moment/space of decision, impelling him to undertake a radically critical and free reading of every component of his situation. Such an absolute responsibility places him in a radically antagonistic relationship to established institutional rules and expectations, and orients him instead towards truth, justice, or humanity to come. Like the Son of God in Paradise Regained, Samson has a mission to accomplish with profound mental and personal implications for his life. In his first soliloquy, he complains about being different from others in 
having "Heav'n-gifted strength" (36), in being "a person separate to God" (31), and being "Designed for great exploits" (32). He explains the unexpected outcomes of his strength and mission as his responsibility:

[...] Promise was that I

Should Israel from Philistian yoke deliver;

Ask for this great deliverer now, and find him

Eyeless in Gaza at the mill with slaves,

Himself in bonds under Philistian yoke;

Yet stay, let me not rashly call in doubt

Divine prediction; what if all foretold

Had been fulfilled but through mine own default,

Whom have I to complain of but myself? (38-46)

Samson is confused and uncertain about the ways that God's promise that he would free his nation should have been fulfilled because he himself is now a captive of the Philistines. While he always believed that his actions were directed towards accomplishing this mission, his words here show that he was never given a prescribed or pre-programmed plan. Milton uses the expression "What if" to show Samson's lack of complete knowledge of what he must exactly do to accomplish his mission. This phrase demonstrates both the hypothetical quality of the aporetic moment/space of decision and what I call Milton's poetics of the to-come because it opens the possibility of becoming a fit reader. Samson is certain about the burden of his heavy responsibility 
and his uncompleted mission, but his ability to pose the question "what if" shows his openness to thinking differently and therefore to possible but not previously considered courses of action. Throughout the poem, Milton shows Samson experiencing the uncertainties and indeterminacies of the aporetic moment/space of decision, its "what if" quality, as fundamental to his ability to think differently about his situation.

A good example of Samson's non-programmed condition and openness is when he suddenly changes his mind and decides to go to the Philistian lords, the outcome of which is not clear to himself or anyone else. The Chorus comments, "How thou wilt here come off surmounts my reach" (1380), and Samson says his decision is taken without any certainty about its consequences:

$[\ldots]$ how the sight

Of me as of a common enemy,

So dreaded once, may now exasperate them

I know not. [...] (1415-18)

Samson has spent his whole life trying to fulfil his mission, but the Son of God is at the very beginning of his mission. Even though the Son is looking onto the prospects of his life and Samson is reviewing his actions and thoughts in the past, both poems are still firmly located in the moment of the to-come, still looking forward. Like Paradise Regained, the question of the to-come is fundamental to this poem as well. 
A strong contrast between Paradise Regained and Samson Agonistes is made apparent when we read that the Son is led by the spirit into the solitude of the wilderness. The phrase "the Spirit leading" seems to provide an immediate divine sanction which is supposedly lacking in Samson Agonistes. Being lead by the Spirit is itself a sign of openness to possibilities, since responding to spiritual intervention is associated with the unpredictable and the incalculable. In Book 3 of Paradise Lost, the Son freely offers himself as a ransom for man and there is no suggestion that God has predestined that decision:

Behold me then, me for him, life for life

I offer, on me let thine anger fall;

Account me man; I for his sake will leave

Thy bosom, and this glory next to thee

Freely put off, and for him lastly die

Well pleased, on me let Death wreck all his rage; (3.236-41)

The Son's decision cannot be a true decision unless it is freely taken. This is true about Samson as well. There has to be the possibility to fall and disobey for Job, Abdiel, the Son, Satan, Adam and Eve, and Samson. In Paradise Regained, the Son is represented as having no supernatural or superhuman capacity to anticipate the future. He has to go through the process of deciding truly about the form of his mission and how to act in the future. Both the Son of God and Samson must fulfil their missions in their own ways but at a time, in a place, and by means that yet they do not know. Samson, like the 
Son and Milton himself, refers to the "divine prediction" that produces a responsibility and the enactment of a singular mission. They acknowledge this but the important point is how to enact that mission or responsibility when the means remain unknown and unrevealed.

There are differences between the extent to which the Son and Samson establish their positions in terms of their doubt and faith in divine prediction. The singularity of the two contexts in each poem creates differences between the poems and the ways they demonstrate the aporetic moment/space of decision. One of the ways by which Milton constitutes the singularity of this moment/space in each poem is the distinctive positioning of the two protagonists in respect of the narrative of their lives. Samson is at the last stage of his life and the fulfilment of his mission seems impossible. The two poems demonstrate their central characters at different moments in the evolution of their mission, emphasizing the notion of the singular example by confirming the possibility that every moment/space in a person's life can become an aporetic moment/space.

\section{Framing the Aporetic Moment/Space}

Throughout the poem, Samson is in an aporetic moment/space in which there is no specific content to define the terms and conditions of a decision in an absolute way. Such a moment/space is abundant with undecidables and indeterminacies. Milton demonstrates the nature of this moment/space by framing its singular space-time location between the social-historical present, the to-come, and its personal-social 
location in Samson's life span and consciousness/mind. His doubts about his understanding of his mission are explored in a mental process of reviewing the imperatives that have led him to this point in his life. The matter is whether he can resolve his unsettled state of mind and uncertainty about what must be accomplished in order to fulfil his mission. The Son and Samson's decisions are individual and singular because of the complex interaction of the knowledge available to them, the realities of their historical time and place and the sense each has of an absolute responsibility.

The contrast between Samson's miserable present condition and his past glorious days is the main problem that leads the Chorus to assert the principle, "Just are the ways of God, / And justifiable to men" (293-4). However, by itself this principle cannot put an end to uncertainties and doubts or define an authoritative course of action. The implication of these comments and assertion of faith by the Chorus for Samson is that as becoming a fit reader he cannot accept any proposal for action derived from it without theoretically and radically testing it. For the fit virtuous mind, any decision has to come from already known, established principles and doctrines, but comes in a way which modifies or interprets them, in ways that have not been interpreted before; this happens in the aporetic moment/space of decision through a radical, critical reading of the knowledge, interpretations, and understandings available in a specific time and place.

The content of an aporetic moment will depend on the singular characteristics of the circumstances and context within which it occurs. Hence, for Samson the specifics of 
that context are in crucial ways different from the Son's. The poems demonstrate the singularity of the aporetic moment of decision by showing how the unpredictability of Samson's final decision and action and the Son's decision to return home, are expressions of a radical, critical, and inward freedom. Samson is faced with a variety of possible actions, like the Son, but also with the immediate need to decide how to act. Furthermore, the meaning and effects of their singular decisions and actions cannot be controlled by them but are shaped by those who witness and interpret them. No one, not even the Son of God, can predict when in that space what the decision/action which resolves the uncertainties will be if that decision is open to the to-come.

\section{II}

In this section, I will discuss the qualities and attributes Samson exemplifies as a fit reader, like the Son of God but in a singular way. I will show Samson's engagement with a performative act of re-evaluation, re-examination, and re-assessment of all the resources of knowledge available to him within his social and historical location. In Milton's thought, Samson's action is not a specific model for others' behaviour. Samson radically experiences the aporetic moment/space of decision by reassessing everything, which has led to his present condition in prison, making a profound critique of his self. The main part of this struggle is to repudiate the calculable represented by the persuasions of significant figures in Samson's life: Manoa, Dalila, Harapha, and the Chorus. They are persistently pushing their demands, models, and desires on Samson. 
His rejection of their arguments parallels the Son's repudiation of Satan's temptations. Samson's decision to act comes out of his intense experience of the aporetic moment/space, and is embodied in creation of an unpredictable singular event. In aporetic moments of decision, there is undecidability, indeterminacy, and suspension of meaning.

\section{Exploration of the Aporetic Moment/Space}

One of the most important things Samson undertakes at this very late moment in his life as a prisoner of the enemies of his people is a profound review of his past. This review is conducted in different forms, for example, in form of a complaint against his whole life, his response to other characters, and his justification of his actions. Readers witness different representations of key events in his past and no single consistent resolution of these accounts is provided. However, a fit reader radically explores everything to make a true and just decision. Milton demonstrates that both Samson and the Son of God perform this imperative private act of radically critical review.

Samson challenges what is known as the accepted knowledge of the time. The inherited maxims, norms, principles, and models of his society are not sufficient grounds for his decision, confirming that Samson is in the moment/space of aporia in which socialpolitical questions of institutions are fundamentally suspended, reexamined, and reinterpreted. Harapha accuses Sampson of being "A murderer, a revolter, and robber" (1180), a criminal who has acted against the established laws and principles (from the 
Philistines' perspective). Appeals and judgments that threaten Samson's ability to act as a fit reader/democratic intellect are exceptionally challenging in Samson Agonistes because of the strong emotional, familial, and intimate connections involved. Samson persists, nonetheless, in adopting a radically analytical and critical approach in his dealing with the established social-political models and forces presented to him.

Encountering Samson's strong stand, the Chorus comments on a group of "just men" (1269) that act "With plain heroic magnitude of mind" (1279). The singular characteristic of this group is their strong minds because of which they are victorious in extremely difficult encounters. The common feature of these true heroes of both the private and public domain is their breathtaking exercise of suffering, questioning, and patience. The Chorus indicates that Samson has these characteristics:

But patience is more oft the exercise Of saints, the trial of their fortitude, Making them each his own deliverer, And victor over all That tyranny or fortune can inflict, Either of these is in thy lot, (1287-92)

The nature of the struggle is individualistic, private and mental, and deliverance from the crisis situation can only be accomplished by the individual who is experiencing it. 


\section{Self-knowledge/Self-Critique and the Problem of Prophecy}

Samson acknowledges his divine mission and his responsibility, but he does not now seek to decide and act according to his previous conception of it. The poem represents him at an intense moment of self-critique. He is questioning his past in a way that more than anything demonstrates his extreme awareness of his mission and duty, and of his failure to fulfil their requirements. In the opening speech of the play, Samson represents a dark picture of his mental conflicts. He complains about his birth "from Heaven foretold" (23) and the way his existence has been "designed for great exploits" (32), which contrasts absolutely with his humiliation and imprisonment. But he also goes further and questions his creation, which shows his willingness to think radically and independently. However, as a fit reader he quickly takes back the complaint and takes responsibility for his situation. By using the phrase "what if" he indicates that there might be other possibilities. Samson indicates that he has no certain knowledge about the way the prophecy about him must be enacted in the world. He then again expresses his faith in God's will and the fact that he has ends unknown to him. He presents the promise or divine prediction about himself as follows:

\section{[...] Promise was that I}

Should Israel from Philistian yoke deliver;

Ask for this great deliverer now, and find him

Eyeless in Gaza at the mill with slaves, Himself in bonds under Philistian yoke; 
Yet stay, let me not rashly call in doubt

Divine prediction; what if all foretold

Had been fulfilled but through mine own default,

Whom have I to complain of but myself? (38-46)

Whatsoever the revelation, prophecy, or prediction, the crucial problem is that it does not prescribe in detail the kind of action which would accomplish that mission. He knows that he has a responsibility to accomplish something and that is because of a unique capacity or capability he has been given. Precisely, "how to act" and "what to do" are unknown to him and yet it is his responsibility to make a decision that would lead to the fulfilment of that promise. In retrospect, he judges that his past decisions have not resolved the uncertainty built into this situation, which is a consequence of its openness to the future. The expression "what if" is an inescapable indication of Milton's poetics of the to-come.

\section{Renunciation of the Calculable}

As discussed in the former sections, Milton shows Samson intensely engaging in the act of revaluing his knowledge in all its dimensions: social, political, religious, historical, and personal. The first step in this profoundly difficult process is to review his understanding of the social, political, and personal factors which brought about his present condition by conducting a radical self-critique in order to develop a distinctive form of self-knowledge and provide the means for achieving inward freedom. Samson 
acquires and demonstrates the characteristics of a fit reader as the poem goes on. The most significant part of this progressively more radical and free process is the suspension of the established laws, principles, conventions, norms, and models available and offered to him. Milton composed the dominant plot and encounters of the drama between the central figure and other characters to demonstrate this process. They are suspended so that he can develop inward freedom and openness to the possibilities of new non-pre-programmed decisions and enactments. Through the rejection of the calculable, Milton is able to foreground the question of the to-come in the whole poem in a way that Samson progressively and fully experiences the aporetic moment/space and develops the qualities and attributes of being a fit virtuous reader.

Samson has four intense encounters or confrontations with the characters around him represented as forces - like Satan's temptations in Paradise Regained - impeding Samson's radically critical reading of his situation and context. The attempts to persuade Samson to take an established model of decision and action, if successful, would place him out of the aporetic moment/space and block the process to become a fit reader. In the aporetic moment/space, institutional models of behaviour cannot be accepted as exemplarily sufficient or comprehensively complete. Samson's encounters with his father, Manoa, then his Philistian wife, Dalila, the Giant Philistian hero, Harapha, and the Chorus, are the focus of my argument in this section.

What Milton argues in Samson Agonistes, like Paradise Regained, is that even a society's social-political maxims are exposed to interpretations and narrations by 
institutions and systems, and they can be employed in a way that would contaminate a person's mind and his power of reading critically, radically, and freely. There is no absolute maxim or law in society that can be applied with certainty in all circumstances. The singularity of each situation shapes the application of laws and rules. That is to say, the Son of God and Samson both renounce the calculable and their approach always remains singular to their own cases. Although the renunciation of the calculable becomes the overall common element and feature of a fit reader's approach, there is no fixed model for performing this act of resistance and renunciation. Samson's approach is singular to his own context and case.

\section{"Better at home lie bed-rid"}

Samson's father, Manoa, offers him retirement at home under his care and for the rest of his life. He invites Samson to have faith in "miracles" rather than in "prophecy" and his "self" because he believes Samson must stay out of public life, having failed in his mission, and only pray for miracles to happen in his life. Manoa believes Samson will not be able to accomplish the mission and it will be carried out by someone else. Manoa's offered model is a political practice, an appeal to the powerful, known and acceptable to the society in which they live. If successful, Manoa would in effect prevent Samson from becoming a fit reader/democratic intellect, and practicing his radically critical and free reading of the social-political models typically framing decisions and actions. 
Manoa's speech starts with his complain about God's prophecy, gifts, and graces in relation to his son. Stricken by the intolerably painful status of his son, he states lack of "trust / In mortal strength" (348-9) indicating his disappointment and remorse in praying to God to give him a son. Manoa asks for the reason God answered his prayer. He questions God's "gifts desirable, to tempt / Our earnest prayers," (358-9), but these graces prove to have "a scorpion's tail behind" (360). He believes that his son's miserable situation is God's punishment for Samson's failure. He argues that the punishment is too extreme for what he first created and promised to be "the miracle of men:"

For this did the angel twice descend? For this

Ordained thy nurture holy, as of a plant;

Select, and sacred, glorious for a while,

The miracle of men: then in an hour

Ensnared, assaulted, overcome, led bound,

Thy foes' derision, captive, poor, and blind

Into a dungeon thrust, to work with slaves? (361-67)

Manoa firmly considers his son's present condition is the very last stage of his mission, a helpless and hopeless failure. There is no hope, according to Manoa, for Samson's return to fulfilling his grand mission. He fundamentally questions the creation of his son, his mission, and the whole prophecy. He even believes that the "worse thing yet 
remains" (433) to come. Public life and reputation is Manoa's main concern: "So Dagon shall be magnified, and God" (440) debased all because of Samson. He claims that the heaviest of Samson's sufferings is the public shame deriving from Dagon's apparent victory: "Of all reproach the most with shame that ever / Could have befall'n thee and thy fathers house" (446-47). For him, Samson's private sufferings or loss of his inward freedom are not as significant as the outward, public shame. ${ }^{85}$

Manoa's understanding of prophecy is different from Samson's. Manoa explains prophecy as if it is a fact or event that will be fulfilled completely, a definitive statement about God's actions in the future.

With cause this hope relieves thee, and these words

I as a prophecy receive: for God,

Nothing more certain, will not long defer

To vindicate the glory of his name

Against all competition, nor will long

Endure it, doubtful whether God be Lord,

Or Dagon. But for thee what shall be done? (472-78)

\footnotetext{
${ }^{85}$ In Paradise Regained, Satan similarly emphasizes the importance of public glory. Manoa and Satan's perspectives are the same here and the result would be the same if the Son or Samson should surrender to their persuasion, preventing the further development of their respective analyses which mark them out as fit readers.
} 
With assurance, Manoa turns his attention to practical matters in relation to Samson's situation: "But for thee what shall be done?" (478). He has "already made way / To some Philistian lords" (481-82) to seek ransom for Samson because he believes his mission is over and "now no more canst do them harm" (486). Manoa does not consider Samson any more as a responsible person with abilities to decide and act freely. He emphasizes his dependence on others and "self-preservation." His suggestion is to "act not in thy own affliction" (503) but "leave to high disposal, / And let another hand" (506-7) work out a beneficial solution. However, Milton demonstrates that Manoa in his calculations is both acknowledging and downplaying uncertainty associated with the tocome anticipating the response of the "Philistine Lords" and God's response to Samson's failure:

Reject not then what offered means, who knows

But God hath set before us, to return thee

Home to thy country and his sacred house,

Where thou may'st bring thy off'rings, to avert

His further ire, with prayers and vows renewed. (516-20)

Furthermore, Manoa strongly appeals to the notion of miracle as an intervention of God that would put an end to Samson's miserable situation. He speaks of possibilities of "light again within thy eyes to spring," (584) or "this strength / Miraculous yet remaining in those locks" (586-7). 
Samson rejects his father's proposals. He still believes in his mission and the prophecy; therefore, he stands against his father's models of behaviour and action by placing his "self" and "mind" outside of the systems which support and dictate those models. Samson locates in himself a radical freedom to decide and reciprocally accepts absolute responsibility. He declares himself to be the "Sole author" (376) of the evils present in his life and blames his own former weak, negligent, and inwardly blind "self." To him, the main reason behind his miseries is:

The mystery of God given me under pledge

Of vow, and have betrayed it to a woman,

A Canaanite, my faithless enemy. (378-80)

He argues that it is only after he surrenders himself inwardly to slavery that outward slavery comes: "Servile mind / Rewarded well with servile punishment" (412/13). Losing inward freedom prevents a person from thinking and acting radically, freely, and critically in relation to the social-political forces of society:

The base degree to which I now am fall'n,

These rags, this grinding, is not yet so base

As was my former servitude, ignoble,

Unmanly, ignominious, infamous,

True slavery, and that blindness worse than this,

That saw not how degenerately I served. (414-19) 
Unlike his father, Samson continues to think about his mission and possible ways to fulfil it. He repudiates his father's offer to accept his failure in accomplishing his mission and remain inactive for the rest of his life:

\section{$[\ldots]$ by which means,}

Now blind, disheartened, shamed, dishonored, quelled,

To what can I be useful, wherein serve

My nation, and the work from Heav'n imposed,

But to sit idle on the household hearth,

A burdenous drone; [...] (562-67)

Samson believes in the notion of prophecy and not miracle. A democratic intellect/fit reader does not rely on miracles because it means complete passivity of the person. Samson believes in 'Prophecy' because it is the revelation of a mission and a responsibility. Prophecy for him signifies the foreshadowing of a possibility without specifications or arrangements so that the person becomes the central object of the prophecy to work out its implications. The concept of 'prophecy' for Samson, unlike Manoa, is primarily an emphasis on the endless process of interpreting, judging, and acting. It is obvious that Samson does not have a clear picture of how he must act as the means of bridging the gap between present and future. He and his father were both certain about his mission and responsibility; now, the question of how to accomplish 
that is unknown to them both, but only Samson continues to think that he could be the means.

\section{"But foul effeminacy held me yoked"}

In Samson Agonistes, the "element of effeminacy" is one of several persuasions and temptations that Samson is encountered with, challenging him as a fit reader and exposing him to strong emotions of family associations and relationships. The element of effeminacy in Samson's case is a negative power which could break his resistance and paralyze the process of his radical critique of social-political authorities that might lead to a just decision and its enactment and the possibility of the revelation of some truth and justice in society. When Dalila comes to Samson, the Chorus describes her as a flower that weeps and encourages Samson to forgive her act that "more evil drew / In the perverse event than I foresaw" (736-37). She explains that her aim is:

$[\ldots]$ to behold

Once more thy face, and know of thy estate.

If aught in my ability may serve

To lighten what thou suffer'st, and appease

Thy mind with what amends is in my power,

Though late [...] (741-46) 
The Chorus refers to the element of woman's beauty and charm as a power - "Yet beauty, though injurious, hath strange power" (1003) - which is, of course, ineffective "to wisest men and best" (1034). This power is categorically "in his way to virtue / Adverse and turbulent" (1039-40) which would draw him to slavery "With dotage, and his sense depraved / To folly and shameful deeds which ruin ends" (1042-43).

Dismayed by Samson's strong and deliberate use of critical and free reading abilities, Dalila has recourse to a difference in the abilities of men and women: "In argument with men a woman ever / Goes by the worse, whatever be her cause" (903-4). She then offers another solution similar to that offered by Manoa, to join her "at home in leisure and domestic ease" (917):

I to the lords will intercede, not doubting

Their favorable ear, that I may fetch thee

From forth this loathsome prison-house to abide

With me, where my redoubled love and care

With nursing diligence, to me glad office,

May ever tend about thee to old age

With all things grateful cheered, and so supplied,

That what by me thou hast lost thou least shalt miss. ${ }^{86}(920-27)$

\footnotetext{
${ }^{86}$ There is a fundamental difference between this retirement to domestic life and the Son of God's retirement at the end of Paradise Regained. This is a parallel situation mentioned in the two poems but with profoundly different contextual characteristics demonstrating that there can be no fixed models or
} 
To justify her disloyal act, Dalila refers to different conditions and reasons. One is a common fault of women, "Curiosity, inquisitive, importune / Of secrets, then with like infirmity / To publish them" (775-77). Other reasons include Samson's inability to keep his secret from Dalila (778-82) and his trust in her: "Nor shouldst thou have trusted that to woman's frailty: / Ere I to thee, thou to thyself wast cruel" (783-84). In her final argument, she interprets Samson's and her "weakness" as the same:

Let weakness then with weakness come to parle,

So near related, or the same of kind;

Thine forgive mine; that men may censure thine

The gentler, if severely thou exact not

More strength from me, then in thyself was found. (785-89)

In her line of argument, based on a variety of grounds and reasons, Dalila does not demonstrate certainty about the position she puts forward. "Love" can be another possible reason for her action. The question of "what if" is mentioned in this case as well: ${ }^{87}$

\footnotetext{
ways of treating different situations because the singularity of any context affects the kind of act to be performed.

${ }^{87}$ Dalila uses this phrase differently. In Paradise Regained, this phrase represents possibility in thought but open into action. Here Dalila is asking Samson to think about her actions in a particular way so that his understanding of what she has done would change. This is the rhetorical use of "what if" as a means of reframing what has occurred in the past.
} 
And what if love, which thou interpret'st hate,

The jealousy of love, powerful of sway

In human hearts, nor less in mine towards thee,

Caused what I did? [...] (790-93)

Her version of the definition of love is self-centred. She argues that she "knew that liberty / Would draw thee forth to perilous enterprises" (803-4); therefore, she tried to do something to keep him at home (imprison him). Now, she even argues that Samson's present condition is much better than his time of liberty: "Here I should still enjoy thee day and night / Mine and love's prisoner, not the Philistines" (807-8). According to her, the law of love justifies her actions.

Samson's response, as Dalila asserts, is "austere" and "inflexible" with "uncompassionate anger" (815-18). This is an exact account of a fit reader's state of mind, someone who does not demonstrate weakness or uncertainty in encountering institutionalized models of interpretation. Her arguments, interpretations, and positions are fully within the social institutions and power structures of the nation to which she belongs. Samson's main difference is due to his repudiation of conventional models and forms of action. As Dalila argues, she is like no one:

Be not unlike all others, not austere

As thou art strong, inflexible as steel.

If thou in strength all mortals dost exceed, 
In uncompassionate anger do not so. (815-18)

In this case, Dalila is a good example of a conventional reader who is a slave to both her inner desires and undoubtedly to the institutional powers. She thinks within the terms of the established systems of thought and action of her own society. Dalila argues that she was unable to resist the "assaults," "snares," and "sieges," around her because such pressures would even make "the best resolved of men" (847) surrender. She says that her reason was not "gold," as Samson claims, but the social, political, religious pressures, which seemed "just" and "powerful arguments" (862) to her at that time. Milton's main concern here is to demonstrate how the reality of an event and an action becomes an effect of the retrospective interpretations of them in contexts different from the time of the action.

It was not gold, as to my charge thou lay'st,

That wrought with me: thou know'st the magistrates

And princes of my country came in person,

Solicited, commanded, threatened, urged,

Adjured by all the bonds of civil duty

And of religion, pressed how just it was,

How honorable, how glorious to entrap

A common enemy, who had destroyed

Such numbers of our nation: and the priest

Was not behind, but ever at my ear, 
Preaching how meritorious with the gods

It would be to ensnare an irreligious

Dishonorer of Dagon: what had I

To oppose against such powerful arguments?

Only my love of thee held long debate;

And combated in silence all these reasons

With hard contest: at length that grounded maxim

So rife and celebrated in the mouths

Of wisest men; that to the public good

Private respects must yield, with grave authority

Took full possession of me and prevailed;

Virtue, as I thought, truth, duty so enjoining. (849-70)

Dalila's argument above is unbelievably helpful and profoundly expressive of complicated processes and conditions a fit reader is exposed to and how persuasive such religious, political, legal, and social interpreting forces in a society can be when they are displayed as truth, virtue, and civil duty. Milton underlines the performative power of language, representation and interpretation and the singular role they play in our recognition of the meaning of an event. Dalila demonstrates the complex, contextual process through which a mind (unfit reader) understands/recognizes truth or virtue, surrenders to authorities beyond such arguments, and ultimately loses both inward and outward freedom to those social-political authorities. That means the main force that "Took full possession of" Dalila was not a physical force or violence, but the force of 
an argument, a performative mental process on the symbolic level performed by means of "preaching" and "in the mouths / Of wisest men," (866-67). Dalila is a good example of an unfit reader who is unable to achieve freedom from conventions, models, and the expectations of systems and structures.

Samson is now sure that what Dalila is trying to do is one of her new "wonted arts" (748). He describes her cunning arts as untrustworthy and makes a generalization against women. He asserts:

Not truly penitent, but chief to try

Her husband, how far urged his patience bears, His virtue or weakness which way to assail:

Then with more cautious and instructed skill Again transgresses, and again submits; (754-58)

Samson knows that this charmingly strong feminine practice has been effective to deceive the "wisest and best men"(759) and refers to his own case with Dalila as "to ages an example" (765). At this stage of developing his capacities to become a fit reader, Samson is critically alert to proposals even from the closest members of his family along with all related emotional pressures and associations. He refers to his submission to woman's power to be remembered as an example to all ages: "As I by thee, to Ages an example" (765). Dalila truly describes Samson's resistance now as "Implacable, more deaf / To prayers, than winds and seas to shore" (960-61). Samson 
recalls his past experiences and his resistance against her feminine temptations and that in the fourth time "unmanly" he could not stand his ground against the "feminine assaults, / Tongue-batteries," (403-4) of his wife and revealed his secret to her:

At times when men seek most repose and rest,

I yielded, and unlocked her all my heart,

Who with a grain of manhood well resolved

Might easily have shook off all her snares:

But foul effeminacy held me yoked

Her bond-slave. O indignity, $\mathrm{O}$ blot

To honor and religion! (406-12)

Samson is in the process of achieving fit reader status. His determination is to free himself from all bonds, so that he can think radically and freely about what is essential in his situation. He no longer surrenders to the affectionate feminine power. Dalila's conventionally and institutionally reasonable interpretations are not working on him because he positions himself outside all the systems. Samson rejects Dalila's justifications and interpretations, emphasizing the importance of inward freedom again and argues, "bitter reproach, but true, / I to myself was false ere thou to me," (823-24). This evinces his radical critique. He indicates that he is quite vigilant and mindful of her argument and will no longer fall into her traps: "In vain thou striv'st to cover shame with shame, / Or by evasions thy crime uncover'st more" (841-2). The violence of his speech to Dalila is a clear expression of the extraordinary effort he has to make to 
separate himself from his past with Dalila in order to become able to think freely in this specific situation. Samson asserts: "I thought where all thy circling wiles would end; / In feigned religion, smooth hypocrisy" (871-72) or "These false pretexts and varnished colors failing, / Bare in thy guilt how foul must thou appear" (901-2)? He continues:

[...] I know thy trains

Though dearly to my cost, thy gins, and toils;

Thy fair enchanted cup, and warbling charms

No more on me have power, their force is nulled,

So much of adder's wisdom I have learned

To fence my ear against thy sorceries.

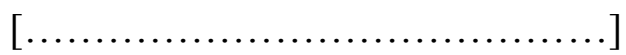

This jail I count the house of Liberty

To thine whose doors my feet shall never enter. (932-50)

The effeminacy that has in Samson's judgment here often influenced his decisionmaking appears practically ineffective in the case of the Son of God in Paradise Regained. Satan totally rejects the use of this male disposition as one of his temptations of the Son. The crucial point here is how the two protagonists distinguish their relations to women responding to the possibility of effeminacy inside them. The Son's and Samson's relationships to woman and the effects of such a potent element in their lives is no doubt an imperative issue for Milton in the two poems. His main purpose is to demonstrate how each character achieves freedom with respect to a force which can be 
negatively limiting. The issue of effeminacy brings into the foreground the exercise of power in male-female relations. Milton contextualizes this power in Paradise Regained and rejects the appropriateness of using such a temptation in the case of the Son. The difference in situation is important and we know that the Son has no experience of marital relations. Woman becomes the means to objectify qualities for the male that can be used to subvert the integrity of thought and action. In Book 2 of Paradise Regained, Satan addresses the other fallen angels, summoning them all "Rather to be in readiness with hand / or counsel to assist" (144-45) him because, after his first round of temptation, he has found this Enemy (the Son of God):

Far other labor to be undergone

Than when I dealt with Adam first of men,

Though Adam by his wife's allurement fell,

However to this man inferior far,

If he be man by mother's side at least,

With more than humane gifts from Heav'n adorned,

Perfections absolute, graces divine,

And amplitude of mind to greatest deeds. (2.132-139)

No doubt, female allurement can be a strong force to some (Adam, for example) to impair them from becoming a fit reader based on specifics of the context. Satan emphasizes the significance of the singularity of each case. A model or fixed behaviour cannot be the reason for the success of an action. The singular contextual, social, and 
personal aspects of each case determine the best way to deal with them. If the allurement of woman and the tendency of effeminacy work in the case of Adam, it is inefficient in case of the Son of God. The Son's difference is summarily manifested his "amplitude of mind." In his works, Milton repeatedly emphasizes the critical power, plenitude and openness of the free mind as the main factor in becoming a fit reader. Belial suggests to "Set women in his eye and his walk" (153) since women are "Expert in amorous arts, enchanting tongues / Persuasive," (158-9) and had the power to soften the heart "Of wisest Solomon, and made him build, / And made him bow to the Gods of his wives" (170-71). Satan's answer is that he misunderstands the singularities of each case and reminds him that you cannot assume that everyone conforms to models and patterns. Satan enlists different examples to highlight the significance of the singularity of contexts: Pellean conqueror (196-98), Solomon (201-4). The Son of God is of no comparison to such figures; he is far wiser, "of more exalted mind," (206) and no woman could be found to be able to allure him and tempt him. Samson endeavours to move towards such a quality which is consistent with the process of analysis and critique of himself he is undertaking.

\section{"Thee he regards not, owns not, hath cut off"}

Samson's encounter with Harapha is the continuation of his experience of being challenged by institutional models and conventional behaviours, urging him act accordingly; however, after the two challenges, he is increasingly getting conscious and mindful at this stage of his life. He is still in the aporetic moment/space of decision- 
making in which he is examining and questioning radically, critically, and freely whatever is represented to him. Samson's refutation of Harapha's position is a further step in the clarification of his mission and acceptance of his absolute responsibility.

Apart from exchanging heroic challenges, Samson and Harapha's focus is to represent different interpretations of the same situations and events to prove each other wrong. This is again a form of fighting on the symbolic level which is not the usual manner of national heroes and giants. Harapha, like Manoa, Dalila, and the Chorus, attempts to urge Samson to accept the interpretations of the Philistines' institutions and surrender to what they regard as institutionally lawful/unlawful, just/unjust, heroic/non-heroic, and acceptable/unacceptable. The struggle is to impede Samson from completing his singular enquiry into what it means to think and act as a radically critical and virtuous reader; to bring him out of the aporetic moment/space in which no institutional model of behaviour can be applied without question to new situations.

In his argument, Harapha pushes the subject towards the truth of their Gods by referring to Samson's heroic actions as the production of "some magician's art" (1133). Samson offers to combat him and "Then thou shalt see, or rather to thy sorrow / Soon feel, whose god is strongest, thine or mine" (1154-55). Harapha brings up one of the significant questions about which Samson himself has complained previously: God has "Left me all helpless" (644). This can be a powerful influence on Samson's mind to turn him against his God, nation, mission, and his own self. There is already more than enough evidence for Samson to doubt the truth and justice of his God and submit to the 
calculable justification presented to him by Harapha, who deduces that whatever his God is:

Thee he regards not, owns not, hath cut off

Quite from his people, and delivered up

Into thy enemies' hand [...] (1157-9)

Nevertheless, Samson remains a vigilant, critical and free reader of such remarks. He works towards finding fundamental reasons for his action and is analysing the institutionally logical and legal arguments. He returns to his own becoming self and identifies not God but his own mental weaknesses and faults as the main causes of evils and despairs in his life. Samson is still positive and hopeful:

All these indignities, for such they are

From thine, these evils I deserve and more,

Acknowledge them from God inflicted on me

Justly, yet despair not of his final pardon

Whose ear is ever open; and his eye

Gracious to readmit the suppliant;

In confidence whereof I once again

Defy thee to the trial of mortal fight,

By combat to decide whose god is God,

Thine or whom I with Israel's sons adore. (1168-77) 
In another part of his argument, Harapha describes Samson as "A murderer, a revolter, and robber" (1180). He is a criminal from the Philistines' perspective. The questions of law, justice, and truth become the main concerns of their arguments. Such fundamental social-political and institutional evaluations are suspended and reinterpreted in this aporetic moment/space. Harapha argues:

Is not thy nation subject to our lords?

Their magistrates confessed it, when they took thee

As a league-breaker and delivered bound

Into our hands: for hadst thou not committed

Notorious murder on those thirty men

At Askalon, who never did thee harm,

Then like a robber stripp'dst them of their robes?

The Philistines, when thou hadst broke the league,

Went up with armed powers thee only seeking,

To others did no violence nor spoil. (1182-91)

In response, Samson argues that "your ill-meaning politician lords" had appointed thirty spies to rob him of his secret. We know that Samson has already defied his nation's laws by marrying a Philistine woman. He also argues that, although his nation "was subjected to your lords" (1205), the force of conquest can be rejected by force "when 
the conquered can" (1207). This is exactly what Samson has to do to deliver his people from the yoke of Philistines:

But I a private person, whom my country

As a league-breaker gave up bound, presumed

Single rebellion and did hostile acts.

I was no private but a person raised

With strength sufficient and command from Heav'n

To free my country; if their servile minds

Me their Deliverer sent would not receive,

But to their masters gave me up for naught,

Th' unworthier they; whence to this day they serve. (1208-15)

Samson does challenge the laws of the systems available to him; he suspends them, reinterprets them, either changes them or at least claims something by acting against a law. He marries a woman from his enemy's nation. He locates himself in systems both his own and his enemy's, suspends their laws and acts as a radically free critical individual mind.

"More lordly thundering then thou well wilt bear"

The Chorus - Samson's friends - makes its own attempt to urge Samson to decide and act according to known social-political models. They play one of the main roles in 
relation to Samson's experience of the aporetic moment/space of decision. The Chorus constantly mentions the possibility of some bad, dangerous outcomes of Samson's decisions and urges him not to refuse the calculable. After Harapha leaves, the Chorus warns Samson of what could possibly happen due to his encounter with Harapha:

He will directly to the lords, I fear, And with malicious counsel stir them up Some way or other yet further to afflict thee. (1250-53)

The Chorus's warning underscores the uncertainty about what might be said and performed in future against Samson. No one knows what might happen and what would be the result of Samson's behaviour. The Chorus's warnings are important because they represent calculable possibilities and fears that must be usually and seriously considered because of their relevance to Samson's decisions and responses. They can also have the effect of diverting Samson from his singular experience of the aporetic moment/space of decision and his readiness to be open to the to-come.

Another example of the potential of the Chorus's interpretation of Samson's situation to persuade him to quit the aporetic moment/space of decision-making is after Samson's refusal to go with the officer to appear before the Philistian lords. The Chorus warns him that his situation will get worse if he refuses to go: 
Consider, Samson; matters now are strained

Up to the highth, whether to hold or break;

He's gone, and who knows how he may report

Thy words by adding fuel to the flame?

Expect another message more imperious,

More lordly thund'ring then thou well wilt bear. (1348-53)

Samson's response to the Chorus's warnings is "no" and that he "dread[s] him not" (1247). Samson is determined to stick to his certainty about the process of suspending the known models and methods and the uncertainty and indeterminacy of what would happen or come as a result. Samson asserts that he welcomes whatever will happen: "My speediest friend, by death to rid me hence, / The worst that he can give, to me the best" (1262-64). He argues that their calculable approach to cases and examples lacks the imperative implications of contexts and their singularity. They respond to Samson's rejection of using his "consecrated gift" (1354) to serve the Philistines by arguing that he has been using it to serve them as their captive: "Yet with this strength thou serv'st the Philistines" (1363); however, Samson differentiates the forced service as work to deserve his food; that by labour "Honest and lawful to deserve my food / Of those who have me in their civil power" (1366-67). Samson argues that when "outward force constrains," the maxim the Chorus mention, "Where the heart joins not, outward acts defile not," (1368) can be true, but when it is a matter of commands, there are no constraints in commands and "if I obey them, / I do it freely" (1372-73). As we can read 
here, Samson foregrounds the crucial effects of context on the maxims, rules, and laws that make interpretation of every case and situation different and unique.

\section{Embodiment of Decision in a Public Action: Creation of an Event}

Samson, like the Son of God, is aware of his mission, but he was given no exact revelation of what he must do to fulfil it. No one knows what he is thinking and determining during the last phase of his deadly action. This is a crucial problematic when seeking agreement on the meaning of an action. In Samson's case, what we have access to as the meaning of actions is only subsequent views and positions which are generated in the terms provided by social institutions. Consequently, the evaluations and interpretations of an action (like Samson's or the Son's) will never come to a point of complete agreement. The questions like "whose action is wrong or right" and "whose action can be entirely defended or condemned" seem to be out of place because judgments are always made within the principles and interests of particular social groups and communities. It is very important to notice that Samson makes no public claim about the meaning of his action. The determination of what an action means is the work of society, to which the performer of the action can also contribute, but it is predominantly a collective and retrospective process.

This idea is decisively demonstrated and confirmed in Samson Agonistes; that is, the poem in its external commentary on Samson does not claim to have the knowledge of what Samson was thinking about at the very moment of making his decision to act. 
Milton does not claim to know what the exact characteristics of the private moment/space of decision are. No narration is provided about the aspects of that singular private moment/space. This moment/space is so private and intrinsic that Milton does not even attempt a fictional representation of it:

\section{[...] when Samson}

Felt in his arms, with head a while inclined,

And eyes fast fixed he stood, as one who prayed,

Or some great matter in his mind revolved.

At last with head erect thus cried aloud,

"Hitherto, Lords, what your commands imposed

I have performed, as reason was, obeying,

Not without wonder or delight beheld.

Now of my own accord such other trial

I mean to show you of my strength, yet greater;

As with amaze shall strike all who behold." (1635-45)

If we remember the narrator's claim in Paradise Lost to have access to the truth, something that without Urania's assistance and the Holy Spirit is impossible - these lines seem extremely noteworthy. Why did Milton not give us a picture of what is going on in Samson's mind in that very moment of decision while he immerses his readers in Samson's state of mind throughout the poem? The techniques like interior monologue or soliloquy are usually used to represent the narration of a state of mind, but he does not 
use this regular method. To Milton the delicacy and privacy of this final moment of decision is so singular and so central to his poetics of the to-come that apparently only God has access to it.

There are many examples of decision-making in Samson's life which run against the conventions and laws of his society. Beside the cases of selecting his wives from hostile tribes, he first acknowledges the importance of following their laws that "forbids at their religious rites, / My presence" as his reason to reject going to Philistines' celebration and service their gods, but later changes his mind and does act against this law. Samson as a fit reader exceptionally considers the contextual imperatives of events and situations in his life. The radical critique of such contextual elements and forces results in a decision that appears completely against the laws and maxims of his nation, but he believes it falls even more into the direction of truth and justice. He offers nothing more specific about the future course of events than his assurance that any act he performs will not dishonour "[o]ur God, our law, my nation, or myself" (1425). Is it justifiable to act against a law and then argue that the action is not in violation of truth and justice, supposedly the aims of any law? This is one of the main features of a group of people who are called "fit readers" by Milton and "democratic intellects" by Derrida. To make a true decision in a situation of uncertainty requires being able to examine the laws and models available to them in their society fundamentally, critically and freely, according to conscience. This is exactly what Samson does because he works to achieve the qualities of consciousness which the Son expresses throughout Paradise Regained. 
Even having a truth framework does not predetermine the way one should act in specific situations. How to enact truth in any given moment of time and place is the question that will never be clear. The complex elements of an aporetic moment/space demonstrate how difficult and uncertain this moment is if its potential is to be worked through rather than closed down by a calculable decision. A fit reader/democratic intellect goes through the intense process of achieving this capability by fully experiencing the aporetic moment of decision. There is no authorization for the act which follows except the individual's own decision. The reference to other sources of authorization like God would not change the fact that responsibility for any action resulting from the aporetic moment/space of decision-making remains private and individualistic. For fit readers, the only acceptable validation of an action is the person's own conviction, however different the evaluations and interpretations might be that are generated by other individuals, groups and institutions in the society to which they belong. The element that gives value and authorization to the action enacted by a fit reader/democratic intellect is that the action is the outcome of a radical, critical, and free process with a singular attention to everything that is known as the knowledge of the time, the specifics of the context and openness to the future. The consideration of the context introduces the fit reader as a highly socialized mind that profoundly shares the future with others. Fit readers in a democracy, to Milton and Derrida, have to consider themselves as highly responsible members of that society for the sake of the to-come. 
It is crucial to remember that the mental process of suspending models and possibilities is not negative at all. It is in fact a process of determining what the fundamental ground is on which the singular action or decision of the fit reader is to be taken. The imperative here is that everything which might lead to the normalisation of a decision or action, and everything that would make it socially and conventionally convenient, has to be eliminated and rejected in order for the democratic ground, conscience, which always represents itself as socially, politically, or institutionally singular, to assert itself. This constant challenging of the established norms and models of society is not negative at all. The fit reader/democratic intellect radically examines them and rejects them as absolute models but considers them as factors when establishing the ground for his own singular decision and action. This ground will be in an unknown, undefined, unlimited space of absolute responsibility.

\section{Conclusion}

The aim of the discussion in this chapter is to demonstrate that the issues, encounters, and characters of Samson Agonistes confirm that this poem, like Paradise Regained, is an exploration of the aporetic moment/space of decision-making. Milton's poetics of the to-come is an overarching frame within which the two poems are interpreted. The notion of the to-come takes us beyond the undecidable; however, Milton demonstrates that no reader can achieve absolute certainty in history. The poems show this condition as the inevitable consequence of living in relation to the future. Milton locates his two late poems on the margin of the to-come. 
The evidence to argue for similarities between the situations in which the central characters are located in the two poems is much stronger than the evidence to argue for their fundamental differences. Although there is a strong contrast between the poems in the central characters' lives and historical locations, their main concern is to represent their experience of the aporetic moment of decision-making. Samson's decision is not predetermined by any existing modelling structures of the society. The exact form of the act he performs to fulfil his mission is never given in advance of its performance.

Nevertheless, Milton did not want to make the similarities and parallels of the lives of the Son and Samson his main concerns in writing the two poems. If his desire in writing his late poems were that, he would have chosen different phases of their lives with more similarities and parallels. For example, if Milton had chosen the phase of the Son's life when he went to Jerusalem, was captured and then crucified, there would be many more similarities between the two poems. The more similarities between the events of the poems, the greater the difficulty would be to grasp the main point of Milton's poems, that is, to demonstrate the importance of the radically critical and free mind and the process through which one can develop such a radical mind. Historical similarities between the two main figures of the poems are not Milton's main concern; instead, the radical critical operation of a free democratic intellect/fit reader absorbs the main energy of arguments in the poems. In addition, Samson does not completely know what it means to be a fit reader, but he works to achieve the qualities of consciousness which the Son expresses throughout Paradise Regained. The difference here is that the Son of 
God is already a fit reader in the sense that from the very beginning he demonstrates those qualities consistently and with full command of himself, but Samson does not. It is also important that Samson had to confront a specific model of heroism. He could not think like the Son of God because there were no similar possibilities in the principles and doctrines of his time. However, the poem finishes in a way that suggests similar heroic qualities represented and confirmed by the central characters in Paradise Regained and Paradise Lost, those related to submission, suffering, and humility. In this respect, historical Samson opens himself to a future possibility, which the Son comes to fully embody.

Individuals possessing the attributes of the democratic intellect are shown experiencing the process of decision-making in an aporetic moment/space in which the precise form of the action they are going to accomplish is unknown until its performance. Such an act is experienced in form of the to-come. The specific outcome of Nelson Mandela's decision to resist the apartheid system remains absolutely unknown and singular even to him until the very moment of enacting the decision. Interpretations and understandings of what he did, his own and those of others, are retrospective. He acts like Abdiel in Paradise Lost, the Son of God in Paradise Regained, and Samson in Samson Agonistes. The actions of the Son of God or Samson are not the main concern and emphasis of the poems; instead, it is the singularity of the process a fit reader/democratic intellect (which can be both the poems' central characters and readers of the poems) experiences when engaged radically, critically and freely in an aporetic moment of decision-making which becomes the imperative of Milton's poems. Milton does not present the actions of 
the Son or Samson as exemplary models for the future. Instead, the poems position their central characters temporarily in a free space outside the terms, conventions, and limits of the societies in which they are located. The effect is to highlight the defining significance of the aporetic moment/space of decision-making and its relation to the tocome for the formation of a democratic intellect/fit reader. The fundamental discovery of each poem is the nature of the radically free and critical state of mind of democratic intellect/fit reader as the premise for true decision and action.

Paradise Regained and Samson Agonistes move from the inevitability of being in and encountering aporetic situations in the moment/space of decision to the unpredictability of acts undertaken in relation to the to-come, from the inward freedom of a person in aporetic moment/space - within which the principles and criteria of systems of thought are suspended - to the unknown status of events to come. The indispensability of the singular experience of the aporetic moment/space for becoming a virtuous, fit reader and the unpredictability of the to-come shifts attention away from the role of God in the decisions Samson and the Son make. The Son and Samson similarly confront the world of moral incertitudes and indeterminacies. The Son knows that moral uncertainties and indeterminacies are deep inside human systems and structures represented to him by Satan, and similarly Samson is meticulous about alternatives presented to him by the intimate people around him. Rather than "undo[ing] each other" (Destabilizing Milton 175), as Herman argues, the two poems supplement each other. This argument affirms the common purpose of each poem as singular poetic works exploring the new quality of mind that is termed by Milton as fit reader and Derrida as democratic intellect. 


\section{Conclusion}

My argument in this thesis is that there are deep continuities between John Milton and Jacques Derrida in their thinking about the fundamentals of law, justice, literature, truth, and democracy. In particular, the juxtaposition of their works makes possible a fuller understanding of Milton's aims, achievements, and thought. The thesis concerns the relationship between Milton and Derrida as exponents of themes and issues fundamental to Western Humanism. I place both the English poet and the postmodern French philosopher in an epistemological middle space between a position of certainty, in which the truth is absolutely known, and one of radical incertitude, in which nothing is true and everything is permitted. Reading the works of the two authors together in the opening chapters has demonstrated important continuities and convergences in their thinking about the qualities of the fit reader/democratic intellect and the role of radical critique. The principal outcome of the discussion in these chapters was their shared focus on a singular individual in the aporetic moment/space of decision, leading to a public act introducing changes into the quality of public space. The texts examined foreshadow the conceptions and conditions which may enable a better human society to be developed. The thesis applies this epistemological model to Milton's two late masterpieces, Samson Agonistes and Paradise Regained, in the last two chapters as singular examples of the fit reader and what I have described as Milton's poetics of the to-come. Both poetic works feature protagonists who struggle with what role they should play in relation to the forces of oppression that confront them. The argument of 
the last two chapters confirms the thesis in detail through the demonstration of the singularity of each poem, the centrality of the aporetic moment/space of decision in both, and the very different situations of the two protagonists. This new understanding of the two works contributes to establishing Milton's living relevance at a time when one faction of Milton criticism would interpret him as the fundamental defender of traditional truth and another group would present him as a poet of radical incertitude and indeterminacy.

Milton believed that there was an Edenic condition in which absolute truth and justice had been present and accessible, but there is now no complete access to them because of the Fall. History for Milton is a condition in which the ongoing process of searching for the scattered components of truth and justice is indispensible. Milton explicitly acknowledges that we can never confidently know whether any particular point of knowledge is indeed true. Such an absolute certainty is for him deferred until Christ's Second Coming. On the contrary, truth for Derrida has no absolute pre-existent form. In his thought, there is nothing outside history or other than history, no prelapsarian or apocalyptic life and world. However, there are deep continuities and convergences between Derrida and Milton thought when we examine their thought about human society and human individuals in history.

Derrida and Milton agree in their acknowledgment of the confusion and lack of absolute knowledge or truth in the world. Both writers understand the human condition in history as full of incompleteness, uncertainties, and indeterminacies with no absolute and fixed 
solution. They utterly endorse the idea that any particular instance of government that is called democracy is delimited and partial in respect of the potential meanings of the term. There is always a gap between the term and any embodiment of its meaning. The human attempts in history have resulted in inadequate, defective establishment of socialpolitical structures on the basis of incomplete, deconstructible, and calculable systems of thought. This ongoing process and struggle in history to implement the meaning of the term democracy, for both Derrida and Milton, is inevitable and absolutely essential. In fact, for both writers this is the only hope for humans in history to extend knowledge and truth and bring more justice to societies. For both authors, there is always the possibility that human societies can become more humane. But how is this ongoing process and struggle to be conducted and who are those responsible for and capable of achieving these goals?

Societies can become different from what they are and evolve to some better form in the future, but this possibility depends entirely on their individual members. For both Derrida and Milton, the crucial point is the achievement of the potential in any society by means of the open, future-oriented decision-making of its individual members. They attach absolute responsibility to the individuals in society to experience and conduct this ongoing process of decision-making for a positive future for society. For them, a better version of human society might come into existence only when individuals in society release themselves from the limitations, regulation, and direction of institutional laws, principles, and determinations. Every individual can be the source of truth and justice only when they radically free their thinking, decision-making, and action from the 
already known models defined and enforced by institutions. Citizens can introduce changes and improvements leading to a better future to their society only when they can think freely, decide freely, and act freely. No fixed or comprehensive model of society is exempt from this radically critical and free approach.

"Fit reader" is the term Milton uses for those demonstrating and developing the qualities and attributes of being such free thinkers. For Derrida, the quality distinguishing this group of individuals is called "democratic intellect." The fundamental common feature of fit readers and democratic intellects is their radically critical and free reading/approach to the knowledge and institutions of their society. This reading occurs within the interval between the traditional and conventional positions of certainty, on the one hand, and of absolute incertitude and indeterminacy, on the other hand. This middle moment/space is revolutionary, indeterminate, and uncertain because fundamental questions and issues can be radically examined and suspended to create an opening towards and a readiness to consider the possibilities in the future, or the tocome. It is the problematic moment/space of "trial" or "aporia" in which radical suspension of current knowledge, laws, and principles enables the mind of the individual to realize new possibilities for truth and justice.

The fit reader/democratic intellect is grounded in a radically critical inward freedom which requires accepting the burden of an absolute responsibility, possibly the most responsible irresponsibility because of the unconventional or socially disruptive actions which may occur during the exercise of this responsibility. A fit reader/democratic 
intellect thinks radically, critically, freely, and questions the very principles of systems on the basis of "something" that functions as a point of reference. That something, called truth, justice, or law to-come, is always different from the defined conceptions available to a society through its institutions. This becomes the measure of the responsible irresponsibility, which has to be a point of reference and simultaneously the outcome of the private experience of the aporetic moment/space of decision. It is a radically critical experience for which the recognition and re-examination of the values, beliefs, principles, doctrines, and knowledge of the society and the singular context of decision is indispensible, a profoundly mental exploration.

The full experience of such a moment/space engages in the act of understanding all the resources of knowledge - moral, religious, historical, political, social, and personal - of the person in the specifics of their social and historical location. The purpose of this act of understanding is to reach a decision to be embodied in a public action. Milton and Derrida explore this issue at their different historical locations and contexts in the ongoing evolution of the concept and practice of democratic society. Although this process happens within a private mental domain, it is essentially social and public in many respects. Even strong principles, like it is simply just or right to do anything that would result in the freedom of a people, do not necessitate a particular, predetermined action for a fit reader/democratic intellect. The main question is how to find and enact truth in any specific time and place and this will never be simply clear and certain. An aporetic moment/space of decision is a radically undecidable and uncertain situation. An aporetic moment is located on the margin between the present and the future, leaning 
towards the future rather than falling back into the past or the present. There is no authority for the action one performs apart from its self-authorization. The only acceptable validation of the action is the person's self-conviction.

A fit reader/democratic intellect is one who does not simply act within the terms of the laws and principles of any specific group or system. Individuals possessing these attributes are capable of radically critical and free reading, reconsidering, re-examining, and re-interpreting the available laws, concepts, and models. Nothing in relation to an act which might follow such an examination can be clearly defined and programmed in advance. This approach leads to the suspension of the already established and accepted models and patterns of behaviour in that society. The exact form of such an act is indeterminate and uncertain until its enactment. A radically critical and free decision, that is, one which opens the possibility for new truth and justice to enter the world, requires acceptance by the fit reader of complete responsibility for it, even though its meaning may not be known at the time. When representations and interpretations of a singular act are formulated, they typically locate the act within the frames of an institution or system. This is exactly what the poems - Paradise Regained and Samson Agonistes - demonstrate as the social response to the singular decisions and acts of their main figures. Their singularity is shown in the way that their decisions and acts are not predetermined and programmed by the systems and institutions available to their different times and places. 
Both Milton and Derrida stress the freely open-ended engagement with the to-come. The notion of the to-come supposes a quality of absolute willingness and readiness to decide and take action without possessing a pre-justification and a claim to certainty about the form of the action. This public action assists and results in coming into being of a new form of society with more possibilities and conditions, a democracy or humanity in the form of the to-come. Openness to the future requires a radical freedom, but the more freedom for decision and action that is taken, the less protection social convention offers for the fit reader/democratic intellect, and the more absolute their responsibility for decision and action.

The juxtaposition of Derrida and Milton resulted in identification of this shared moment of aporia/trial and the notion of the to-come. To view Milton's works and thought on the basis of this "poetics of the to-come" provides a new and productive understanding of thee indeterminacies and uncertainties in some of Milton's works. Milton wants us to think like a fit reader in this aporetic moment/space with no fixed models or attitudes. In different contexts and situations, such a reader figures out the most responsible decision (which may also be the true and just decision) decision and Paradise Regained and Samson Agonistes are supreme examples of this situation and this kind of reading. In the final two chapters of the thesis, I argue that the Son of God and Samson, in Paradise Regained and Samson Agonistes, must be considered as singular examples of Milton's fit reader, the characteristics of whom he was performatively and persistently presenting throughout his works, both prose and poetry. The terms and questions discussed in the opening chapters in relation to his prose works, I argue, are 353 
exhaustively gathered up and exemplified in his last two poems. My thesis is that Paradise Regained and Samson Agonistes similarly represent the aporetic moment/space of decision and Milton's poetics of the to-come to emphasize the singularity of each moment/space of decision and its enactment in each poem.

The crucial part of the process of being in an aporetic moment/space of decision is the suspension of established principles, rules, and models. Fit reader fundamentally suspends these values and beliefs and radically re-assesses, re-interprets, and re-defines them. This is exactly what the Son of God and Samson do in terms of what their societies provide for them. The renunciation process of respected models and possibilities is not negative at all. It is the process of declaration and admiration of the fundamental ground on the basis of which a fit reader's radical decision and action is taken. Everything leading to the normalization of the decision and act which would make them socially and conventionally convenient has to be eliminated in order for the democratic ground, conscience, and singularity to become fundamentally clarified. This ground and conscience always represents itself as socially, politically, and institutionally singular. The seemingly invariable saying NO to established norms and models is neither negative nor antagonistic nor pessimistic. Rather, it is the radical recognition, reevaluation, re-interpretation, and re-admiration of institutionalized values and principles of life, which play the main role in such a decision-making process.

Neither Samson nor the Son of God have access to a democratic system in the historical situations in which they are located; however, they develop and exemplify the qualities 
of the fit reader by being in and going through aporetic moments/spaces of decisionmaking for the sake of democracy or humanity to come. Samson and the Son of God judge the past against their present circumstances, and neither character makes a claim to having knowledge of absolute truth, while believing that it will be made available when needed. No doubt, Milton thinks as a Christian; yet, within and with these parameters, his thought as demonstrated in his works, especially Paradise Regained and Samson Agonistes, is remarkably radical, critical, and deconstructive. The Son of God and Samson are not living in democratic societies, but the process of decision-making within the aporetic moment demonstrated in the poems is similar to the process of decision-making fundamental to the configuration and continuation of democracy and humanity.

I discussed some instances of Milton's prose and poetic works in the light of this epistemological model, which was derived from considering some of Derrida's writings. Further application can be made to other singular examples of Milton's fit reader in his works that could not be discussed within the scope of this thesis. To view Milton's thought in the light of the poetics of the to-come provides a consistent perspective for re-interpretation of his works and their problematic indeterminacies and contradictions. 


\section{Bibliography}

Achinstein, Sharon. "John Milton's Spectre in the Restoration: Marvell, Dryden, and Literary Enthusiasm." Huntington Library Quarterly 59 (1997): 1-29.

---. Literature and Dissent in Milton's England. New York: Cambridge UP, 2003.

---. Milton and the Revolutionary Reader. Princeton, NJ: Princeton UP, 1994.

---. "Milton Catches the Conscience of the King, 'Eikonoklastes' and the Engagement Controversy." Milton Studies 29 (1992): 143-63.

Ainsworth, David. Milton and the Spiritual Reader: Reading and Religion in Seventeenth-Century England. New York: Routledge, 2008.

Anderson, Kemmer. "Those Tenured Tyrants: How Milton's Tenure of Kings and Magistrates Influenced Jefferson's Declaration of Independenc." Milton in France. Ed. Christophe Tournu, New York: Peter Lang, 2008.

Appelbaum, Robert. "Milton, the Gunpowder Plot, and the Mythography of Terror (Garry Wills)." Modern Language Quarterly 68 (2007): 461-91.

Arenas of conflict: Milton and the unfettered mind. Eds. Kristin P. McColgan and Charles W. Durham. London: Associated UP, 1997.

Barker, Arthur E. "Calm Regained through Passion Spent: The Conclusions of the Miltonic Effort." The Prison and the Pinnacle. Ed. Balachandra Rajan, Toronto: Toronto UP, 1974.

Barker, Francis. Literature and Power in the Seventeenth Century: Proceedings of the Essex Conference on the Sociology of Literature, July 1980. Colchester: 
University of Essex, 1981.

Belsey, Catherine. John Milton: Language, Gender, Power. Oxford and New York: Blackwell, 1988.

Benjamin, Walter. Critique of Violence. New York: Harcourt Brace Jovanovich, 1978.

Blase, Vincent. "Milton's Areopagitica and the Modem First Amendment." Yale Law School Occasional Papers 211995.

Blau, Sheridan D. "Milton's Salvational Aesthetic." The Journal of Religion 46 (1966): 282-95.

Blum, Abbe. "The Author's Authority: Areopagitica and the Labour of Licensing." Remembering Milton. Eds. Mary Nyquist and Margaret W. Ferguson, New York: Methuen, 1987.

Bradford, Richard. The Complete Critical Guide to John Milton. New York: Routledge, 2001.

Michael, Bryson. "From Last Things to First: The Apophatic Vision of Paradise Regain'd." Visionary Milton: Essays on Prophecy and Violence. Eds. Peter E. Medine, John T. Shawcross, and David V. Urban, Pittsburgh, Pennsylvania: Duquesne UP, 2010.

---. "A Poem to the Unknown God: 'Samson Agonistes' and Negative Theology." Milton Quarterly 42 (2008): 22-43.

---. The Tyranny of Heaven: Milton's Rejection of God as King. Newark London: Delaware UP, 2004.

Carey, John. "'Samson Agonistes' and September 11 (John Milton)." Times Literary Supplement 5190 (2002): 15. 
---. "A Work in Praise of Terrorism?" Times Literary Supplement 6 (2002): 15-16.

Coffey, John. "Pacificist, Quietist, or Patient Milton? John Milton and the Restoration." Paradise Regained in Context: Genre, Politics, Religion. Ed. Albert C. Labriola and David Loewenstein, Milton Studies Special issue of 42 (2002): 149-74.

Coiro, Anne Baynes. "Fable and Old Son: Samson Agonistes and the Idea of a Poetic Career." Milton Studies 36, 1998.

Corns, Thomas N. Uncloistered Virtue: English Political Literature, 1640-1660. Oxford and New York: Oxford UP, 1992.

Creaser, John. "Prosodic Style and Conceptions of Liberty in Milton and Marvell." Milton Quarterly 341 (2000): 1-13.

Curkpatrick, Stephen. "Mandela’s 'Force of Law."' Sophia 41 (2002): 63-72.

Daniel, Clay. "Royal Samson." Milton Studies 46 (2006): 123-148.

Danielson, Dennis Richard. The Cambridge Companion to Milton. 2nd ed. Cambridge, and New York: Cambridge UP, 1999.

Dzelzainis, Martin. "Introductio" to John Milton. Political Writings, Ed. Martin Dzelzainis. Cambridge: CUP, 1991.

Dean, Margaret Justice. "Martyrdom reconsidered: Adam's profit from Abdiel's example." Milton in France, Ed. Christophe Tournu, New York: Peter Lang, 2008.

Derrida, Jacques. Acts of Literature. New York: Routledge, 1992.

---. Acts of Religion. New York: Routledge, 2002.

---. Demeure: Maurice Blanchot. Paris: Galilée, 1998.

---. The Ear of the Other: Otobiography, Transference, Translation: Texts and 359 
Discussions with Jacques Derrida. Trans. Peggy, Kamuf. New York: Schocken Books, 1985.

---. Eyes of the University: Right to Philosophy 2. Stanford and California: Stanford UP, 2004.

---. The Gift of Death. Trans. David, Wills. Religion and Postmodernism. Chicago: CUP, 1995.

---."An Interview with Jacques Derrida." Cardozo Life, Fall 1998.

---. "'Justices."' Critical Inquiry 31 (2005): 689-721.

---. Learning to Live Finally: An Interview with Jean Birnbaum. Crows Nest, N.S.W.: Allen \& Unwin, 2007.

---. Of Grammatology. Trans. Gayatri Chakravorty, Spivak. Baltimore: Johns Hopkins UP, 1976.

---. The Other Heading: Reflections on Today's Europe. Bloomington: Indiana UP, 1992.

---. "The Politics of Friendship." The Journal of Philosophy 85 (1988): 632-644.

---. Positions. London: Athlone, 1981.

---. Specters of Marx: The State of the Debt, the Work of Mourning, and the NeW International. Trans. Bernd Magnus and Stephen, Cullenberg. New York: Routledge, 1994.

---. A Taste for the Secret. Trans. Giacomo, Donis and Webb, Eds. Giacomo Donis and David. Malden, MA: Polity, 2001.

---. Writing and Difference. Chicago: Chicago UP, 1978.

Derrida, Jacques, et al. Deconstruction and Pragmatism. London: Routledge, 1996. 
Derrida, Jacques, et al. Islam and the West: A Conversation with Jacques Derrida. Chicago: Chicago UP, 2008.

Derrida, Jacques, and Marie-Louise Mallet. The Animal That Therefore I Am. New York: Fordham UP, 2008.

Derrida, Jacques, Laurence Simmons, and Heather Worth. Derrida Downunder. Palmerston North, NZ: Dunmore P, 2001.

Derrida, Jacques, and Thomas Dutoit. On the Name. Stanford, Calif.: Stanford UP, 1995.

Diekhoff, John S. "The General Education of a Poet: John Milton." The Journal of General Education 14 (1962): 10-21.

Dobranski, Stephan B. "Letter and Spirit in Milton's 'Areopagitica'." Milton Studies 32 (1996): 131-52.

---. Milton in Context. Cambridge and New York: Cambridge UP, 2010.

Dobranski, Stephen B., and John Peter Rumrich. Milton and Heresy. Cambridge, and New York: Cambridge UP, 1998.

Dolloff, Matt. "Urania, antidote to tyranny." Milton in France. Ed. Christophe Tournu, New York: Peter Lang, 2008. 89-95.

Donnelly, Phillip J. Milton's Scriptural Reasoning: Narrative and Protestant Toleration. Cambridge and New York: Cambridge UP, 2009.

Duran, Angelica. "The Last Stages of Education: 'Paradise Regained' and 'Samson Agonistes."' Milton Quarterly 34 (2000): 103-17.

Durham, Charles W. "'Suffering for Truth's Sake:' The Conflict between Abdiel and Satan in 'Paradise Lost."' Cea Critic 68 (2006): 60-66. 
---. "To-Stand-Approved-in-Sight-of-God, Abdiel, Obedience, and Hierarchy in 'Paradise Lost' + Milton, J." Milton Quarterly 26 (1992): 14-20.

Dzelzainis, Martin. "Dating and Meaning: Samson Agonistes and the 'Digression' in Milton's History of Britain." Milton Studies 48 (2008): 160-77.

Ellwood, Thomas. The History of the Life of Thomas Ellwood. London: Methuen, 1900.

Fish, Stanley E. "To the Pure All Things Are Pure: Law, Faith, and Interpretation in the Prose and Poetry of John Milton." Law \& Literature 21 (2009): 78-92.

---. "Why Milton Matters: A New Preface to His Writings." Milton Quarterly 41 (2007): 195-97.

---. How Milton Works. Cambridge: Harvard UP, 2001.

Fish, Stanley E, Michael Lieb, and Albert C. Labriola. Milton in the Age of Fish: Essays on Authorship, Text, and Terrorism. Pittsburgh, Pa.: Duquesne UP, 2006.

Fixler, Michael. "Milton's Passional Poetics, or Paradigms Lost and Regained." Milton Studies (2001): 106-49.

Giaman, Barlett. A Free and Ordained Space: The Real World of the University. New York: Norton, 1990.

Gore, Jeffrey. "Obedience in Of Education and Paradise Lost." Milton Studies 46 (2007): 1-29.

Gregory, Tobias. "The Political Messages of Samson Agonistes." Studies in English Literature 1500-1900 50 (2010): 175-203.

Guibbory, Achsah. "Charles's Prayers, Idolatrous Images, and True Creation in Milton's Eikonoklastes." Of Poetry and Politics: New Essays on Milton and His 
World, Ed. P. G. Stanwood, Binghamton: Medieval and Renaissance Texts and Studies, 1995, 283-94.

---. "Rethinking Millenarianism, Messianism, and Deliverance in Paradise Regained." Milton Studies 48 (2008): 135-59.

Guss, Donald. L. "Enlightenment as Process - Milton and Habermas." Pmla-Publications of the Modern Language Association of America 106 (1991): 1156-69.

---. "The Power of Selfhood - Shakespeare 'Hamlet', Milton 'Samson."' Modern Language Quarterly 54 (1993): 483-511.

Habermas, Jurgen. Philosophy in a Time of Terror : Dialogues with Jurgen Habermas and Jacques Derrida. Chicago: Chicago UP, 2003.

Hawkes, David. "Milton among the Pragmatists." University of Toronto Quarterly 77 (2008): 923-39.

---. "Milton's Prudent Ambiguities: Words and Signs in His Poetry and Prose." Milton Quarterly 45 (2011): 55-58.

Herman, Peter C. Destabilizing Milton: "Paradise Lost" And the Poetics of Incertitude. New York: Palgrave Macmillan, 2005.

---. "Milton and Religious Violence." Pmla-Publications of the Modern Language Association of America 120 (2005): 1642-43.

---. "Paradigms Lost, Paradigms Found: The New Milton Criticism." Literature Compass 2 (2005): 1-26.

Hiles, Jane. “Milton's Royalist Reflex: The Failure of Argument and the Role of Dialogics in Eikonoklastes." Spokesperson Milton: Voices in Contemporary 
Criticism. Eds. Charles W. Durham and Kristin Pruitt McColgan, Selinsgrove PA: Susquehanna UP, 1994, 87-100.

Hill, Christopher. Milton and the English Revolution. London: Faber \& Faber, 1977.

Hillier, Russell M. "The Good Communicated: Milton's Drama of the Fall and the Law of Charity." Modern Language Review 103 (2008): 1-21.

Hallways, Tyrus. "Milton's Theory of Education." College English 5 (1944): 376-79.

Illo, John. "The misreading of Milton." Radical Perspective in the Arts, Ed. Lee Baxandall, Harmondswoorth: Penguin, 1972.

Jennings, Theodore W. Reading Derrida/Thinking Paul: On Justice. Stanford and California: Stanford UP, 2006.

Keeble, Neil H. "Wilderness Exercises: Adversity, Temptation, and Trial in Paradise Regained." Milton Studies 42 (2002): 86-105.

Kelsey, Sean. "The Trial of Charles I." English Historical Review 118 (2003): 583-616.

Kendal, Willmore. "How to read Milton's Areopagitica." Journal of Politics 22 1960: $439-73$.

Kerrigan, William. "The Sacred Complex: On the Psychogenesis of 'Paradise Lost."' Cambridge: Harvard UP, 1983.

Kneidel, Gregory. Rethinking the Turn to Religion in Early Modern English Literature: The Poetics of All Believers. New York: Palgrave Macmillan, 2008.

Knoppers, Laura L. Historicizing Milton: Spectacle, Power, and Poetry in Restoration England. Athens: Georgia UP, 1994.

Knott, John R. Discourses of Martyrdom in English Literature, 1563-1694. Cambridge: CUP, 1993. 
---. "'Paradise Lost' and the Fit Reader." Modern Language Quarterly 45 (1984): 123-43.

Kolbrener, William. Milton's Warring Angels: A Study of Critical Engagements. Cambridge: CUP, 1907.

Kuzner, James. "Habermas Goes to Hell: Pleasure, Public Reason, and the Republicanism of Paradise Lost." Criticism: A Quarterly for Literature and the Arts 51 (2009): 105-45.

Lewalski, Barbara K. "Barbara K. Lewalski on Why Milton Matters." Milton Studies 44 (2005): 13-21.

---. "The Genres of Paradise Lost." The Cambridge Companion to Milton (1999): 79-95.

---. "How Poetry Moves Readers: Sidney, Spenser, and Milton." University of Toronto Quarterly 80 (2011): 756-68.

---. The Life of John Milton: A Critical Biography. Oxford, UK: Blackwell Publishers, 2000.

---. "Milton and Idolatry." Studies in English Literature 1500-1900 43 (2003): 213-32.

---. "Milton, Divine Revelation and the Poetics of Experience." Milton Studies 28 (1992): 3-21.

Lieb, Michael. The Dialectics of Creation: Patterns of Birth \& Regeneration in Paradise Lost. Amherst: Massachusetts UP, 1970.

---. Theological Milton: Deity, Discourse and Heresy in the Miltonic Canon. Pittsburgh, Pa.: Duquesne UP, 2006.

Loewenstein, David. "The Alternative Trinity: Gnostic Heresy in Marlowe, Milton, and Blake." Modern Language Review 96 (2001): 465-67.

---. "An Ambiguous Monster, Representing Rebellion in Milton Polemics and 'Paradise 365 
Lost."' Huntington Library Quarterly 55 (1992): 295-315.

---. "'Casting Down Imaginations:' Milton as Iconoclast." Criticism: A Quarterly for Literature and the Arts 31 (1989): 253-70.

---. Milton and the Drama of History: Historical Vision, Iconoclasm, and the Literary Imagination. England: Cambridge UP, 1990.

---. "Milton and the Terms of Liberty." Renaissance Quarterly 57 (2004): 394-95.

---, Representing Revolution in Milton and His Contemporaries: Religion, Politics, and Polemics in Radical Puritanism. Cambridge UK: Cambridge UP, 2001.

---. "The War against Heresy in Milton's England." Milton Studies 47 (2008): 185-218.

Loewenstein, David, and James Turner. Politics, Poetics, and Hermeneutics in Milton's Prose: Essays. Cambridge and New York: Cambridge UP, 1990.

Lucy, Niall. A Derrida Dictionary. Malden, MA: Blackwell Pub., 2004.

McKnight, Laura B. "Crucifixion or Apocalypse? Refiguring the Eikon Basilike." Religion, Literature, and Politics in Post-Reformation England, 1540-1688. Eds. Donna B. Hamilton and Richard Strier, Cambridge: CUP, 1996, 138-60.

Magnus, Elisabeth M. "Originality and Plagiarism in Areopagitica and Eikonoklastes." English Literary Renaissance 21, 1 (1991): 87-101.

Major, John M. "Milton's View of Rhetoric." Studies in Philology 64 (1967): 685-711.

Mandela, Nelson, Jacques Derrida, and Mustapha Tlili. For Nelson Mandela. New York: Seaver Books, 1987.

Martin, Thomas L. "On the Margin of God, Deconstruction and the Language of Satan in 'Paradise Lost'." Milton Quarterly 29 (1995): 41-47.

Marvell, Andrew, and Nigel Smith. The Poems of Andrew Marvell. Pearson Longman, 366 
2003.

Mason, Tung. "The Abdiel Episode: A Contextual Reading." Studies in Philology 62 (1965): 595-609.

McBride, Kari B., and John C. Ulreich. "Answerable Styles: Biblical Poetics and Biblical Politics in the Poetry of Lanyer and Milton." Journal of English and Germanic Philology 100 (2001): 333-54.

Medine, Peter E., John T. Shawcross, and David V. Urban. Visionary Milton: Essays on Prophecy and Violence. Pittsburgh, Pa.: Duquesne UP, 2010.

Milton, John. The Complete Poetry and Essential Prose of John Milton. Eds. William Kerrigan, John P. Rumrich, Stephen M. Fallon, New York: Modern Library, 2007.

---. The Complete Prose Works of John Milton. Ed. Merritt Y. Hughes, New Haven: Yale UP, 1953.

The Milton Reading Room. Ed. Thomas H. Luxon, http://www.dartmouth.edu/ milton, from March 2008 to Sept. 2012.

Mintz, Susannah B. Threshold Poetics: Milton and Intersubjectivity. Newark London and Cranbury, NJ: Delaware UP, 2003.

Mohamed, Feisal G. "Confronting Religious Violence: Milton's 'Samson Agonistes."' PMLA - Publications of the Modern Language Association of America 120 (2005): 327-340.

---. "John Milton: A Hero of Our Time." Clio. A Journal of Literature History and the Philosophy of History 39 (2010): 245-50.

---. "Liberty before and after Liberalism: Milton's Shifting Politics and the Current 
Crisis in Liberal Theory." University of Toronto Quarterly 77 (2008): 940-60.

---. "Reading Samson in the New American Century." Milton Studies 46 (2006): 14964.

Morrissey, Lee. "Eve's Otherness and the New Ethical Criticism." New Literary History 32 (2001): 327-34.

Myers, Benjamin. '"Following the Way Which Is Called Heresy:' Milton and the Heretical Imperative." Journal of the History of Ideas 69 (2008): 375-93.

---. Milton's Theology of Freedom. Berlin, and New York: Walter de Gruyter, 2006.

---. "Predestination and Freedom in Milton's 'Paradise Lost."' Scottish Journal of Theology 59 (2006): 64-80.

Netzley, Ryan. "How Reading Works: Hermeneutics and Reading Practice in 'Paradise Regained.'" Milton Studies 49 (2008): 146-66.

---. "Reading Events: The Value of Reading and the Possibilities of Political Action and Criticism in 'Samson Agonistes.'" Criticism: A Quarterly for Literature and the Arts 48 (2006): 509-33.

Neufeld, Matthew. "Doing without Precedent: Applied Typology and the Execution of Charles I in Milton's 'Tenure of Kings and Magistrates."' Sixteenth Century Journal 38 (2007): 329-44.

Norbrook, David. "Areopagitica, Censorship, and the Early Modern Public Sphere." The Administration of Aesthetics: Censorship, Political Criticism, and the Public Sphere. Ed. Richard Burt, Minneapolis: Minnesota UP, 1994.

---. "Republican Occasions in 'Paradise Regained' and 'Samson Agonistes.'" Milton Studies 42 (2002): 122-48. 
---. Writing the English Republic: Poetry, Rhetoric, and Politics, 1627-1660. Cambridge and New York: Cambridge UP, 1999.

Nyquist, Mary, and Margaret W. Ferguson. Remembering Milton: Essays on the Texts and Traditions. New York: Methuen, 1987.

Oldman, Elizabeth. "Milton, Grotius, and the Law of War: A Reading of 'Paradise Regained' and 'Samson Agonistes.'" Studies in Philology 104 (2007): 340-75.

Parker, William Riley. Milton: A Biography. Oxford: Clarendom Press, 1996.

Patterson, Annabel M. John Milton. London and New York: Longman, 1992.

Peters, John G. "Father, King, and God: John Milton's Prose Response to Monarchy." Midwest Quarterly 49 (2008): 228-44.

The Politics of Discourse: The Literature and History of Seventeenth-Century England. Eds. Sharpe, Kevin, and Steven N. Zwicker. California: University of California Press, 1987. 204-29.

Poole, Kristen. "Naming, Paradise Lost, and the Gendered Discourse of Perfect Language Schemes." English Literary Renaissance 38 (2008): 535-59.

Rajan, Balachandra. "'Samson Hath Quit Himself/Like Samson."' Milton Quarterly 41 (2007): $1-11$

---. "'Simple, Sensuous and Passionate."' The Review of English Studies 2184 (1945): 289-301.

---. "'To Which is Added Samson Agonistes."' The Prison and the Pinnacle. Ed. Balachandra Rajan, Toronto: Toronto UP, 1974.

Rapaport, Herman. Milton and the Postmodern. Lincoln: Nebraska UP, 1983.

Riggs, William G. "Poetry and Method in Milton's 'Of Education.'" Studies in 369 
Philology 89 (1992): 445-69.

Rivers, Isabel. Classical and Christian Ideas in English Renaissance Poetry: A Students' Guide. Boston: G. Allen \& Unwin, 1979.

Rovira, James. "Gathering the Scattered Body of Milton's 'Areopagitica."' Renascence Essays on Values in Literature 57 (2005): 87-102.

---. "Milton's Ontology of Books and Areopagitica." Milton in France. Ed. Christophe Tournu, New York: Peter Lang, 2008. 89-95.

Rumrich, John. "Milton Poetics of Generation." Texas Studies in Literature and Language 38 (1996): 191-208.

---. "Milton's Theanthropos: The Body of Christ in 'Paradise Regained.'" Milton Studies 42 (2002): 50-67.

---. Milton Unbound: Controversy and Reinterpretation. Cambridge and New York: Cambridge UP, 1996.

---. "Milton's Arianism: Why It Matters." John Milton: Twentieth-Century Perspectives, Volume 4: Paradise Lost. Ed. Evans, J. Martin. New York: Routledge, 2003. 143-160.

---. "Uninventing Milton." Modern Philology 87 (1990): 249-65.

Samuel, Irene. "Development of Miltons Poetics." Pmla-Publications of the Modern Language Association of America 92 (1977): 231-40.

Sandler, Florence. "Icon and Iconoclast." Achievements of the Left Hand. Eds. Michael Lieb and John T. Shawcross, Amherst: Massachusetts UP, 1974, 160-84.

Schaeffer, John D. "Metonymies We Read By: Rhetoric, Truth and the Eucharist in Milton's 'Areopagitica."' Milton Quarterly 34 (2000): 84-92. 
Scott, Cohen. "Counterfeiting and the Economics of Kingship in Milton's 'Eikonoklastes.'" Studies in English Literature 1500-1900 50 (2010): 147-74.

Shawcross, John T. The Development of Milton's Thought: Law, Government, and Religion. Pittsburgh, Pa.: Duquesne UP, 2008.

Shore, Daniel. "'Fit Though Few:' Eikonoklastes and the Rhetoric of Audience." Milton Studies 45 (2006): 129-48.

---. "Things Unattempted . . Yet Once More." Milton Quarterly 43 (2009): 195-200.

Shoulson, Jeffrey. "Review of Milton Studies 48. Milton and Historicism." Journal of the Midwest Modern Language Association 43 (2010): 117-20.

---. "Milton and Enthusiasm: Radical Religion and the Poetics of 'Paradise Regained.'" Milton Studies 47 (2008): 219-57.

Smith, Greg. "Binary Opposition and Sexual Power in 'Paradise Lost."' Midwest Quarterly 37 (1996): 383-99.

Steadman, John M. The Wall of Paradise: Essays on Milton's Poetics. Baton Rouge: Louisiana State UP, 1985.

Taylor, Patricia R. "The Son as Collaborator in 'Paradise Regained.'" Studies in English Literature 1500-1900 51 (2011): 181-197.

Togashi, Go. "Milton and the Presbyterian Opposition, 1649-1650: The Engagement Controversy and the 'Tenure of Kings and Magistrates', Second Edition (1649)." Milton Quarterly 39 (2005): 59-81.

Walker, Julia M. "The Poetics of Antitext and the Politics of Milton's Allusions." Studies in English Literature 1500-1900 37 (1997): 151-71.

Wittreich, Joseph. "Between Two Pillars: The Hero Plight in 'Samson Agonistes' and 
'Paradise Regained."' Renaissance Quarterly 58 (2005): 1055-56.

---. "Delirious Milton: The Fate of the Poet in Modernity." Renaissance Quarterly 59 (2006): 1330-32.

---. '"He Ever Was A Dissenter:' Milton's Transgressive Maneuvers in Paradise Lost." Arenas of Conflict: Milton and the Unfettered Mind. Eds. Kristin Pruitt McColgan and Charles W. Durham. Cranbury, NJ: Susquehanna UP, 1997: 2140.

---. "Lost Paradise Regained: The Twin Halves of Milton's Epic Vision." University of Toronto Quarterly 80 (2011): 731-55.

---. "Rethinking Milton Studies: Time Present and Time Past." Milton Quarterly 39 (2005): $140-42$.

---. Why Milton Matters: A New Preface to His Writings. Basingstoke, and New York: Palgrave Macmillan, 2006.

Wolcher, Louis E. "The Man in a Room: Remarks on Derrida's Force of Law." Law and Critique 7 (1996): 35-64.

Wong, Samuel Glen. "Echoes of Paradise: Epic Iteration in Milton." Part Two: Reflections on the Sequel, Eds. Paul Budra and Betty A. Schellenberg, Toronto: Toronto UP, 1998. 68-94.

Woods, Susanne. "Elective Poetics and Milton's Prose." Politics, Poetics, and Hermeneutics in Milton's Prose. Eds. David Loewenstein and James Grantham Turner, New York: Cambridge UP, 1990. 